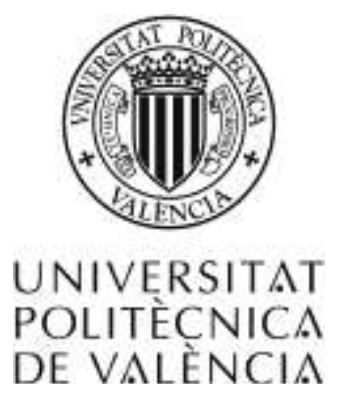

UNIVERSIDAD POLITÉCNICA DE VALENCIA

FACULTAD DE BELLAS ARTES

DEPARTAMENTO DE CONSERVACIÓN Y RESTAURACIÓN DE BIENES CULTURALES

\title{
EL LENGUAJE VISUAL DE LA ARQUITECTURA-ESCULTURA DE LA ZONA ARQUEOLÓGICA DEL TAJÍN, PATRIMONIO DE LA HUMANIDAD
}

AUTOR: LORENA GERTRUDIS VALLE CHAVARRÍA

DIRECTORES: Dr. D. JOSÉ M. VIVÓ LLOBAT Dra. Dña. PILAR ROIG PICAZO 
AGRADECIMIENTOS:

\section{A DIOS}

A mi esposo Carlos y a mi hijo Eric Iván que son mi fuerza y motivación,

A mis padres $y$ hermanos

A la Universidad Autónoma de Tamaulipas y su Rector José Maria Leal Gutiérrez, por haberme brindado la valiosa oportunidad de realizar estos estudios; asi también agradezco al Arq. Eduardo Arvizu y Dra. Teresa de J. Guzmán por impulsar la superación académica y profesional de los docentes,

A la Dra. Pilar Roig Picazo, Directora del Departamento de Conservación y Restauración de la Universidad Politécnica de Valencia a quien expreso mi gratitud por su confianza y facilidades para llevar a cabo este trabajo,

Mi especial reconocimiento al Dr. José M. Vivó Llobat, Director de esta tesis por su invaluable apoyo y guia, y principalmente por su gran calidad humana. 


\section{ÍNDICE}

INTRODUCCION.................................................... 17

ANTECEDENTES Y JUSTIFICACION DEL TEMA...............25

OBJETIVOS Y METODOLOGÍA DE LA

INVESTIGACIÓN.................................................30

\section{PRIMERA PARTE: EL CONTEXTO PREHISPÁNICO}

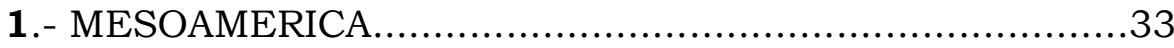

1.1 Concepto y ubicación geográfica de Mesoamérica.

1.2 Áreas culturales.

1.3 Períodos históricos.

1.4 Características de la civilización de Mesoamérica.

1.4.1 El mito-magia-religión.

1.4.2 Quetzalcoatl, deidad suprema de Mesoamérica.

1.5 Los conceptos fundamentales del arte prehispánico. 
2.1 Remojadas y su legado artístico.

2.1.1 La ofrenda mortuoria de El Zapotal, Veracruz.

2.2 Cerro de Las Mesas.

2.3 Complejo de Yugos-Hachas-Palmas.

3.- LA CULTURA DEL TAJÍN .105

3.1 Ubicación geográfica.

3.2 Arqueología general e historia del sitio.

3.2.1 Nombramiento como Patrimonio de la Humanidad.

3.3 Etapas de desarrollo urbano de la zona arqueológica de El Tajín.

3.3.1 Fase I

3.3.2 Fase II

3.3.3 Fase III

SEGUNDA PARTE: EL LENGUAJE DEL ARTE DE EL TAJIN

4.- CONCEPTO DE LENGUAJE VISUAL...........................139

4.1 El lenguaje visual y sus componentes básicos.

4.2 La percepción de la imagen y la Gestalt.

4.3 Modelo de análisis formal para el lenguaje visual de la Cultura de El Tajín. 
5.- ELEMENTOS FORMALES DE LA ARQUITECTURA-ESCULTURA DE EL TAJIN 159

5.1 Talud-tablero/nicho-cornisa volada y sus variaciones Formales.

5.2 La greca escalonada y sus variaciones formales.

5.3 La cruz y los rombos entrecruzados.

5.4 Yohualichan y otros sitios.

6.- ANALISIS MORFOLOGICO DE LA ARQUITECTURA-ESCULTURA DE EL TAJIN

6.1 Edificios de la Plaza del Arroyo.

6.2 Edificios de Tajín Central.

6.3 Edificios de Tajín Chico.

6.4 Edificio de las Columnas, Edificio 42.

7.- EL ESTILO CLÁSICO DE VERACRUZ

7.1 Los tableros del Juego de Pelota Norte y Juego de Pelota Sur.

7.1.1 El Juego de Pelota Norte, Edificios $11 / 11$ bis.

7.1.2 El Juego de Pelota Sur. 
TERCERA PARTE: IMPORTANCIA DEL LENGUAJE VISUAL.

8.- EL LENGUAJE VISUAL DE EL TAJIN Y SU PAPEL

EN LA CONSERVACION, RESTAURACIÓN Y

DIFUSION DE ESTE PATRIMONIO UNIVERSAL................275

8.1 La importancia del aspecto formal de la imagen para la interpretación iconográfica e iconológica de los bajorrelieves escultóricos en los edificios de El Tajin.

8.2 La réplica escultórica, ejemplo de la conservación y difusión del lenguaje visual de la arquitecturaescultura de El Tajín.

8.3 Permanencia e influencia de la obra artística de El Tajín en el arte contemporáneo.

CONCLUSIONES Y REFLEXIONES FINALES. .302

BIBLIOGRAFÍA

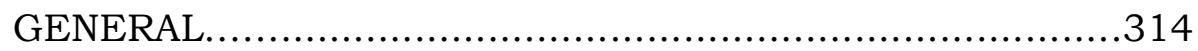

BIBLIOGRAFÍA

ESPECÍFICA................................................. 320

ARTÍCULOS EN PUBLICACIONES PERIÓDICAS...............326

ARTÍCULOS O PONENCIAS EN CONGRESOS...................328 


\section{ÍNDICE DE GRÁFICOS}

No. 1 Mapa de Mesoamérica y sus áreas culturales.................33

No. 2 Escena mitológica con árbol de cacao.........................34

No. 3 Distribución de Mesoamérica...................................35

No. 4 Periodización de Mesoamérica en el contexto de la Historia de México................................................39

No. 5 División de los 22 pisos del cosmos............................42

No. 6 Oxomoco y Cipactónal.........................................44

No. 7 Primera página del códice Fejérváry-Mayer, con los cuatro rumbos del universo...........................46

No. 8 Serpiente emplumada. Cultura mexica. Posclásico Tardío...50

No. 9 Talud y tablero del Templo de Quetzalcoatl, Teotihuacan.................................................5 52

No. 10 Representación de Ehécatl-Quetzalcoatl con Ehecacozcatl....................................................53

No. 11 Sello prehispánico de un colibrí...............................58

No. 12 Representación estilizada de un JAGUAR. Pintura mural. Clásico Temprano. Pórtico10. Conjunto de los Jaguares. Teotihuacan, Edo.de México....................................59

No. 13 Representación sígnica de movimiento (Ollin, lengua náhuatl.) Friso de la Pirámide de los Nichos, Tajín............60

No. 14 Árbol cósmico maya. Templo de la Cruz Foliada, Palenque, Chiapas, México..................................62

No. 15 Tepeyóllotl-Tezcatlipoca, dios jaguar Códice Borbónico.......62 62

No. 16 Detalle escultórico. Templo de la Serpiente Emplumada en Teotihuacan.

No. 17 Urna funeraria con la Diosa del Maíz.

Cultura zapoteca...........................................64

No. 18 Mapa geográfico actual de los sitios arqueológicos de Veracruz......................................................68

No. 19 Bracero para quema de copal.

Fase Remojadas Superior (200 a.C.-800 d.C.)................76

No. 20 Cabeza antropomorfa con tocado en forma de guajolote.

Fase Remojadas Inferior (1000 a.C.-100 a.C.).................76

No. 21 Mono con ruedas y pintura de chapopote.

Cultura de Remojadas, Veracruz............................ 77

No. 22 Perro en posición sedente y pintado con chapopote.

Cultura de Remojadas, Veracruz..............................77

No. 23 Figuras al pastillaje, dios narigudo derecha Remojadas Superior...........................................79

No. 24 Figura femenina de $47.3 \mathrm{~cm}$. con rostro sonriente y signo de ollin en el tocado. Remojadas Superior. 
No. 25 Personaje procedente de El Zapotal. Se observa la greca escalonada como detalle en su indumentaria y restos de betún negro característico de Remojadas..........................80

No. 26 Representación de Tláloc. 48 X 27 cm.

Clásico tardío. El Zapotal.

No. 27 Mictlantecuhtli, el descarnado Señor de la Muerte/Ofrenda mortuoria en El Zapotal, Veracruz/Clásico tardío...............82

No. 28 Cihuateotl, Clásico Tardío, El Zapotal Cerámica $120 \times 52 \mathrm{~cm}$.

No. 29 Cihuateotl, Clásico Tardío, El Zapotal

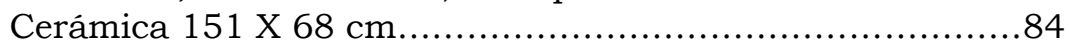

No. 30 Caritas sonrientes. Clásico Tardío. El Zapotal...................84

No. 31 Osamentas acompañadas de figurillas "caritas sonrientes" Ofrenda a Mictlantecuhtli de El Zapotal, Veracruz...............85

No. 32 Dibujo de tiesto cerámico con diseño de volutas.

Cerro de las Mesas................................................ 87

No. 33 Estela 6 Cerro de las Mesas.................................... 87

No. 34 Estela 8 Cerro de las Mesas...................................... 87

No. 35 Monolito de piedra de gran formato. Muestra los ojos con volutas ampliamente utilizado en El Tajín para representar a sus deidades..................................................... 88

No. 36 Escultura hueca del Dios Viejo del Fuego Huehueteotl........88

No. 37 Dibujo e Ilustración de la estela de Tepatlaxco..................90

No. 38 Yugo Tajín, Costa del Golfo. Piedra. Profusamente decorado a base de volutas y en la parte frontal se aprecia un cráneo humano..............................................................99

No. 39 Yugo Cerrado con alto y bajorrelieves. Clásico Tardío, Costa del Golfo, Veracruz. Andesita 42 X $53 \mathrm{~cm} . . . \ldots \ldots \ldots \ldots . . . .93$

No. 40 Yugo liso con improntas de pies. El Zapotal, Veracruz 42 X 32.5 X $10 \mathrm{~cm}$. Piedra gris MAUV ..........................99

No. 41 Hacha de rostro con casco muy elaborado y con volutas.....97

No. 42 Hacha con rostro estilizado. Piedra verde 21.5 X $17.5 \mathrm{~cm} . . .97$

No. 43 Hacha que muestra a un personaje antropomorfo: cuerpo humano y cabeza de ciervo o venado trabajado con líneas dobles.................................................................97

No. 44 Hacha que representa a una guacamaya estilizada; muestra ganchos o volutas estilo Tajín..................................97

No. 45 Palma integrada por 3 secciones individuales representan cuchillos de sacrificio unidos, por una cuerda ritual, que sostiene 4 manos.................................................. 100

No. 46 Palma, Veracruz. Retrato de jugador con enorme tocado con volutas/Justin Kerr Collection...............................100

No. 47 Palma cocodrilo. Costa del Golfo/piedra. $66 \times 22.9 \times 13 \mathrm{~cm}$ 
No. 48 Jugador de Pelota, relieve en piedra arenisca de El Tajín. Fase Cacahuatal, 350-600 d. C. Veracruz...................101

No. 49 Lápida de Aparicio. Aparicio, Veracruz. Clásico Piedra

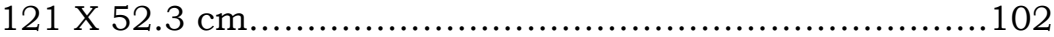

No. 50 Ubicación de la zona arqueológica de El Tajín en el mapa de la República Mexicana y en detalle de la Costa del Golfo de México...........................................................108

No. 51 Representación gráfica de la zona arqueológica de El Tajín extraída de la revista México Desconocido "El Tajin" núm.6,

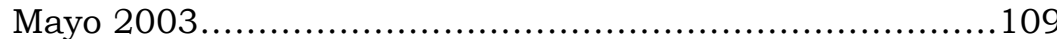

No. 52 Grabado que acompaña a la publicación de Pedro José Márquez sobre la Pirámide de los Nichos...............111

No. 53 Litografia realizada por Karl Nebel de la Pirámide

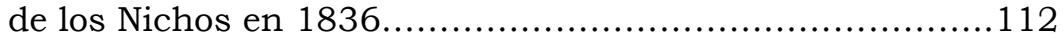

No. 54 Fotografia de archivo propiedad de José García Payón, El Tajín en 1938.

No. 55 Fotografia de las columnas con bajorrelieves como las encontró García Payón...

No.56 Fachada, planta y detalles arquitectónicos y escultóricos de la Pirámide de los Nichos, realizados por el arquitecto José García Payón.

No. 57 Soporte rectangular de vaso tripode cilindrico, Fase Cacahuatal (350-600 d.C.).

No. 58 Respaldo de un espejo de piedra pulida labrado en el centro-norte de Veracruz y encontrado en una ofrenda funeraria de Kaminaljuyú, Guatemala.......................125

No. 59 Mapa de El Tajín.............................................130

No. 60 Pirámide teotihuacana/Corte de un tablero teotihuacano

Típico........................................................... 161

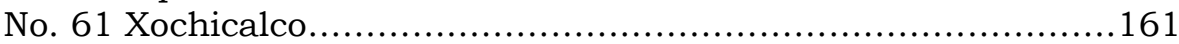

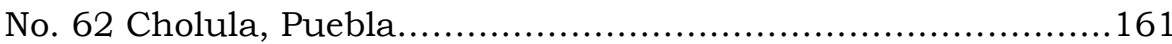

No. 63 Tajín, Veracruz............................................ 162

No. 64 Fotografia de un nicho de la Pirámide de los Nichos derecha/ dibujo lineal del nicho izquierda....................163

No. 65 Forma tridimensional de nicho................................ 163

No. 66 Nichos en perspectiva......................................... 164

No. 67 Algunas variaciones de talud, tablero/nicho, cornisa volada presentes en El Tajín..................................165

No. 68 Nichos con mayor elaboración y profundidad visual lograda debido a varias sucesiones de paredes interiores en su recubrimiento. Se perciben como nichos dentro de otros nichos. Edificio D Tajín Chico...........................166

No. 69 Isométrico y vista lateral de un talud-nicho-cornisa volada168 No. 70 Gran Xicalcoliuhqui, Tajín................................. 168 
No. 71 Agrupamiento de un macizo de 3 nichos consecutivos Edificio 1 Tajín...................................................169

No. 72 Agrupamiento de un macizo de 8 nichos en secuencia horizontal procedente del Edificio 18, Grupo del Arroyo....169

No. 73 Ejemplo de remate del Edificio 5, nichos en sucesión Horizontal........................................................... 170

No. 74 Edificio 23. Izquierda; detalle de nicho........................170

No. 75 Nichos falsos formados por el espacio negativo que dejan las grecas escalonadas. Edificio C, Tajin Chico..................171

No. 76 Detalle de nicho con greca escalonada en su interior y columnillas cilindricas de marco exterior. Edificio de las Columnillas.........................................................171

No. 77 Caracol cortado. Cultura Huaxteca.............................173

No. 78 Imagen pintada de Ehécatl-Quetzalcoatl en el Códice Borgia, portando en su pecho el símbolo del caracol Cortado............................................................ 173

No. 79 Detalle escultórico del Edificio C....................................177

No. 80 Detalle de alfardas de Pirámide de los Nichos..................178

No. 81 Detalle de Edificio 5..........................................178

No. 82 Detalle de Edificio 5. Gran Greca o Xicalcoliuhqui.............178

No. 83 Acercamiento de un plano de El Tajín con la Gran Greca y el Tajín Chico....................................................179

No. 84 Detalle remate de alfarda Edif. C, Tajín Chico..................180

No. 85 Greca formando una cruz swástica. Detalle constructivo del Edificio A, Tajín Chico.............................................180

No. 86 Cruz Chacana...................................................... 181

No. 87 Secuencia de cruces.............................................181

No. 88 Redes modulares de 4 grecas escalonadas en simetría axial de dos ejes............................................... 181

No. 89 Detalle exterior del Palacio de las Columnas en Mitla, Oaxaca.................................................................. 182

No. 90 Grecas diversas en Mitla...........................................182

No. 91 Arriba dibujo de Cruz en movimiento o swástica en positivo. Abajo: Detalle de decoración en estuco del corredor interior del Edificio A, Tajín Chico.....................185

No. 92 Cancha para el juego de pelota 13-14 con acercamiento del detalle de la cruz dentro de los nichos del remate.

No. 93 Detalle escultórico del Edificio D, Tajín Chico...................186

No. 94 Reconstrucción hipotética del Edificio D........................186

No. 95 Detalle de rombos en la alfarda de la fachada sur del Edificio H, Tajín Chico.............................................187

No. 96 Dibujos lineales sobre ejemplos de diseños utilizando todos los elementos que se han mencionado....................188

No. 97 Pirámide monumental en Yohualichan, Puebla presenta un lenguaje visual similar a El Tajín.............................190 
No. 98 Fachada norte del Edificio A en Misantla, Veracruz, que presenta, en medio de la escalinata, un pasadizo que conduce hacia la parte central de la plataforma superior. Es notable el remate de las alfardas en talud del edificio con el elemento formal de las grandes cornisas...

No. 99 Cornisas semejantes en la plataforma del Edificio 5 de El Tajín.

No. 100 Representación de una pirámide escalonada típica teotihuacana en donde se muestran sus elementos formales generales más característicos

No. 101 Los trazados compositivos empleados en Amerindia: el cuadrado, la Grilla, el Rectángulo Raíz 2 y el Rectángulo Áureo...........................................................200

No. 102 Mapa de la zona del Tajín......................................202

No. 103 Traza geométrica Edificio 19.................................203

No. 104 Geometría Edificio 16.......................................205

No. 105 Geometría Edificio 18......................................207

No. 106 Traza geométrica Edificio 20..............................209

No. 107 Geometria del Edificio 1 o Pirámide de los Nichos...........212

No. 108 Detalle de nicho en transparencia, Pirámide de los Nichos, Tajín..............................................2 14

No. 109 Traza geométrica del Edificio 5..............................216

No. 110 Reconstrucción del Edificio 3, Tajín Central.................218

No. 111 Geometria del Edificio 3..................................219

No. 112 Pirámide de Chichén Itzá. Ejemplo del uso de paneles en los cuerpos de la pirámide................................220

No. 113 Reconstrucción de García Payón en perspectiva del Edificio A......................................................223

No. 114 Detalles escultóricos del Edificio A. Grecas segundo Nivel........................................................223

No. 115 Arco tipo maya en El Tajín..................................223

No. 116 Geometría del Edificio A...................................224

No. 117 Estado actual del Edificio A, Tajín Chico....................225

No. 118 Geometría del Edificio C......................................2227

No. 119 Grecas escalonadas en secuencia dirección horizontal Edificio C, Tajín Chico....................................228

No. 120 Macizo central, Edificio 3.................................228

No. 121 Geometría del Edificio de las Columnas. Reconstrucción hipotética de García Payón................................230

No. 122 Edificio de las Columnas....................................232

No. 123 Edificios 11 bis y 11 del Juego de Pelota Norte durante los trabajos de restauración...............................244

No. 124 Dibujos lineales a detalle de franjas verticales del Juego de Pelota Norte.................................................245

No. 125 Tablero suroeste del Juego de Pelota Norte..................246 
No. 126 Frisos superiores de tablero noroeste, noreste y sureste con desdoblamientos del personaje en dirección derecha e izquierda; se observan los diferentes diseños circulares en su vientre.

No. 127 Detalle de dibujo de entrelaces 248

No. 128 Tablero sureste con personaje femenino del lado izquierdo, de los escasos ejemplos de representación de la mujer en el sitio.

No. 129 Traza geométrica de Tablero Noroeste del Juego de Pelota Norte.

No. 130 Lado sur del Edificio 5 y Juego de Pelota sur................252

No. 131 Tablero noroeste Juego de Pelota sur..........................252

No. 132 Tablero NO (noroeste)...........................................253

No. 133 Fig. 132. Tablero NE (noreste) ..............................253

No. 134 Dibujo lineal de detalle escultórico de Tablero suroeste del JPS.........................................................254

No. 135 Dibujos a detalle del signo de ollin del JPS.................255

No. 136 Dibujos detalle escultórico de los frisos del JPS..............255

No. 137 Detalle escultórico del JPS....................................256

No. 138 Detalle escultórico de parte superior de friso. JPS..........256

No. 139 Diversas maneras de representación del signo ollin en el arte antiguo de Mesoamerica, a,b,c Teotihuacan; d,Códice Borbónico; e, Códice Florentino; f, Códices Borbónico y Borgia............................................257

No. 140 Personaje constante en los tableros del Juego de Pelota Sur con dos orientaciones....................................258

No. 141 Tablero SO (suroeste)..........................................259

No. 142 Tablero SE (sureste) ........................................259

No. 143 Traza geométrica de Tablero Noroeste.........................260

No. 144 Tablero central norte, Juego de Pelota Sur...................261

No. 145 Tablero central sur, Juego de Pelota Sur.....................262

No. 146 Izquierda: representación de la planta del maguey en el tablero central norte. Derecha: Diosa del maguey Mayahuel en el Códice Laud...................................265

No. 147 Traza geométrica del Tablero Central Sur....................266

No. 148 Tablero noroeste JPS en el cual se aprecian 5 ojos con volutas indicados con zona de color...........................269

No. 149 Detalles recortados de tablero JPS............................270

No. 150 Detalles recortados de tablero JPS........................271

No. 151 Detalles de animales en tablero JPS..........................271

No. 152 Figuras humanas representadas en tablero de JPS........272

No. 153 Detalle de Cancha para el Juego de Pelota con pelota central en tablero noroeste de JPS.............................273

No. 154 Detalle de Templo con almenas y personaje en el interior, tablero central sur de JPS 
No. 155 Ejemplo de la reproducción virtual de una escultura por la empresa Deco Escultura...........................292

No. 156 Detalle de La civilización totonaca. 1950. Palacio

Nacional, Ciudad de México...

No. 157 Obra Kgakilhtamakú (La bóveda celeste) de Beatriz Leal. Instalación orgánica en Cumbre Tajín 2007, Papantla, Veracruz. México.

\section{INDICE DE TABLAS}

No. 1 Cuadro cronológico de los totonacas............................73

No. 2 Cronología de la región de El Tajín.............................126

No. 3 Tabla de constantes formales en fachadas principales........236

No. 4 Tabla de constantes compositivas geométricas...

239 


\section{INTRODUCCION}

Toda experiencia visual envía un universo de información a su espectador capaz de ser comprimido dentro de una imagen, y es la imagen en sí misma la única con ese poder de transformación inmediato y que además no puede codificarse de ninguna otra forma; en otro sentido, representa un documento no verbal, de gran poder comunicativo y de fijación en nuestra memoria, de ahí su fuerza e importancia. Para lograr esa efectividad, la imagen se encuentra organizada, con una estructura definida y con un lenguaje propio que emana de su naturaleza, es decir el lenguaje visual.

El lenguaje visual así comprendido cobra importancia a partir de la década de los años 60 y 70 dentro de los estudios del arte, cuando se considera al arte como lenguaje o acto de comunicación y que además debía ser analizado frente a otros lenguajes, puesto que la obra artística tiene su propio lenguaje específico, que condiciona toda la experiencia visual.

La antigua cultura de El Tajín asentada en la costa del Golfo de México hace más de 1700 años, ha dejado un legado artístico único porque desarrolla su particular lenguaje visual, tangible en su arquitectura, escultura, pintura mural, etc. Si bien, El Tajín forma parte del contexto histórico, ideológico y religioso de las altas culturas de Mesoamérica: Teotihuacan, Monte Albán, Mayas, Olmecas... de las cuales recibe influencias muy importantes de diversa índole, también es 
verdad que estas servirán para generar un estilo y lenguaje propio sin precedentes en Mesoamérica.

$\mathrm{Su}$ aportación más significativa dentro de la historia de la arquitectura precolombina es un elemento formal y estructural conocido como "nicho", que se encuentra visible en la mayoría de las construcciones del sitio (que comprenden desde pirámides, palacios, templos, etc.) como una oquedad y que tiene en su parte superior una cornisa saliente, que con audacia constructiva, desafia las leyes de la gravedad, pues pareciese que queda al aire. El resultado es una combinación de nicho-cornisa con la estructura teotihuacana de el taludtablero; en El Tajín todos sus edificios son únicos en el uso de estas combinaciones formales, representando una verdadera propuesta creativa de innovación y modernismo, además de los avanzados conocimientos de ingeniería y otras ciencias de sus constructores.

La Pirámide de los Nichos es el edificio más conocido actualmente, entre otras cosas, por contabilizar 365 nichos en sus cuerpos escalonados (asociados con los 365 dias del año solar); en su morfología compositiva se resume bellamente el pensamiento visual de los habitantes de la antigua y sagrada ciudad de El Tajín.

En relación a los elementos esculturales que van unidos a las construcciones arquitectónicas conformando una sola imagen estructural, y por lo cual se usará el término arquitecturaescultura en esta investigación, están representados por un lenguaje plástico cuya imagen predominante es la estilización 
de ganchos o volutas que se enlazan entre sí mismas, y con otros elementos, recibiendo el nombre de estilo Tajin o más correctamente, estilo clásico veracruzano ${ }^{1}$, por desarrollarse durante el período clásico (150/200 a 900 d.C.) en el área geográfica del Estado de Veracruz. El estilo Tajín se manifiesta tanto en la arquitectura, escultura, pintura mural, cerámica, armonizando dichas expresiones artísticas bajo un solo lenguaje visual integrador y unificador.

En la zona arqueológica se han recuperado hasta el momento 168 edificaciones que incluyen pirámides, templos, palacios, juegos de pelota, altares, algunos con pintura mural. En este trabajo se utilizan casos de estudio de edificaciones arquitectónicas-escultóricas significativas que sirvan para ejemplificar este análisis.

El estudio del lenguaje visual de la arquitectura-escultura de El Tajín posibilita para adentrarse en la configuración y estructuración interna de los elementos formales, la relación entre las unidades visuales más simples que se van organizando geométricamente en formas más complejas utilizando técnicas, provocando las cualidades de percepción y sensación en el receptor (como por ejemplo la sensación de movimiento), cuyas leyes fueron estudiadas por la escuela de la Gestalt. Con todo ello se pretende identificar las constantes formales que constituyen los parámetros o pautas estéticas de

\footnotetext{
${ }^{1}$ Nombre dado por Tatiana Proskouriakoff, quien estudió esta manifestación artística de las culturas asentadas en la Costa del Golfo de México.
} 
esta cultura, indicativas del pensamiento creador de sus ejecutores.

Estas son herramientas que se deben tener presentes si se ahonda en su estudio y que pueden representar un factor decisivo para una mejor lectura del discurso visual, permitiendo una mayor comprensión a la vez de proporcionar más recursos para la interpretación profunda de la obra; además del innegable valor plástico-artístico, la arquitecturaescultura en El Tajín funciona $y$ existe en su propia cosmovisión del universo, que se entiende a través del pensamiento mítico-mágico-religioso; el espectador está frente a una obra cuya estética depende totalmente del realismo sagrado y mítico. De ahí su fuerte atracción y magnetismo que ejerce ante la contemplación de los edificios y templos que realizaron sus artistas anónimos, ya que no son ellos, sino la obra en sí misma, la que tiene el máximo protagonismo: portadora del mensaje, del poder y la sabiduría ancestral encerrada en cada una de sus piedras, invita a preguntar el por qué y para que de su existencia. Estos cuestionamientos son el motor que motiva hacia el camino de la investigación profunda de todas las expresiones de su cultura, y el lenguaje visual es el punto de partida para el estudio de la obra desde el punto de vista formal.

Las primeras noticias que se tienen de la existencia de la ciudad de El Tajín son a partir de la publicación en el diario La Gazeta de México el 12 de julio de 1785 en que se habla de la Pirámide de los Nichos, descubierta casualmente. A partir de 
ese momento, El Tajín atrajo la atención de diversos personajes y viajeros; posteriormente se empezaron los trabajos encaminados principalmente al desmonte, consolidación y restauración de los edificios que estaban cubiertos por la selva tropical propia de la región húmeda costeña. Tarea necesaria e inmediata que requería de la intervención de arquitectos y arqueólogos como García Payón, cuya estancia de varias décadas contribuye a la construcción y rescate de la historia de El Tajín. Con dedicación y entrega investiga, explora y restaura gran parte de la zona arqueológica. Es con el Proyecto Tajín a cargo de Jüergen K. Brüeggemann, en 1984, y un equipo multidisciplinar de antropólogos, arqueólogos, historiadores, arquitectos, restauradores, conservadores, etc., cuando se establecen las fases de su desarrollo urbano, se contabilizan y documentan edificaciones así como se crea un corpus escultórico y de la pintura mural encontrada, también de la cerámica y fragmentos de obsidiana, de barro y de piedra pulida. Se construye el Museo del Sitio donde se albergan parte de estas piezas, así como esculturas de bulto, frisos escultóricos, reconstrucción de la pintura mural, etc.

A partir de los resultados obtenidos y debido a la importancia tanto por la extensión y calidad de sus monumentos, la UNESCO (Organización de las Naciones Unidas para la Educación, la Ciencia y la Cultura), reconoce como Patrimonio Cultural de la Humanidad a la ciudad de El Tajín en el año de 
1992, y más recientemente, en el año 2009, a la Danza de los Voladores de Papantla, expresión del patrimonio cultural inmaterial e intangible en El Tajín.

Se confronta, con gran responsabilidad, el estudio de este bien patrimonial con el objetivo de aportar mayores posibilidades de avanzar en un campo poco estudiado, como lo son los aspectos formales dentro del lenguaje visual; se han hecho estudios importantes, como se verá en los antecedentes del tema, pero falta ahondar más en este sentido. El estudio del lenguaje visual proporciona nuevas alternativas de investigación $\mathrm{y}$ perspectivas diferentes que guardan valiosa información de la obra artística.

En El Tajín, todavía queda mucho por hacer para llegar a esclarecer algunas de las incógnitas que siguen sin resolverse; hoy es posible el acceso al patrimonio material y tangible de sus templos, pirámides, palacios; no es así en lo referente a textos escritos o códices que aportaran mayor conocimiento.

No obstante, y como se ha venido afirmando, podemos contar con la valiosa oportunidad de contemplar su arte, que establece un vínculo inmediato a manera de diálogo expresivo a través de su lenguaje no verbal, con su propia sintaxis y cuyo sistema de códigos se está en camino de interpretar.

Un punto de vista interesante es el del arqueólogo e investigador Arturo Pascual Soto, que ha realizado estudios sobre la iconografia de El Tajín bajo el concepto de "unidades signicas o lexemas" representadas en la escultura como 
elementos formales indivisibles que pueden representar parte de un sistema codificado de comunicación. Estos, a su vez, forman asociaciones sígnicas que son sustituciones materiales de conceptos y no pueden existir como tales si no es dentro de un sistema organizado de comunicación. Por otro lado, detectar las variaciones formales (lenguaje visual) que van generando estos "signos básicos o lexemas" a través de su estudio y análisis, permite identificar con mayor claridad los cambios, registrando nuevas unidades sígnicas. Estos cambios son naturales y propios de un sistema de comunicación dados por la necesidad social, cultural y también formal y estética.

Acercarse al estudio de una cultura antigua a través de sus imágenes arquitectónicas con su propio lenguaje visual y consideradas únicos documentos tangibles sobrevivientes, representa una linea de investigación que viene a complementar su estudio desde otra óptica.

Si se reflexiona que este patrimonio ha sobrevivido más de 1700 años al tiempo, al abandono de la ciudad, a la invasión extranjera, y que hoy en día se encuentra ante nosotros, se reconocerá la necesidad de seguir profundizando en el.

No hay duda de lo que la fuerza de las imágenes impacta en la mente humana. Algunas quedan grabadas en la memoria visual haciendo eco de su pasado, como en El Tajín. Sin embargo, estas siguen estando presentes y vivas aquí y ahora. La influencia que tiene el arte de El Tajin en la actualidad es 
palpable en la obra de artistas plásticos de la importancia de Diego Rivera en el mural titulado "La civilización totonaca". Ello es un ejemplo de la permanencia y vitalidad de su lenguaje visual.

El acercarse a comprender los parámetros de su morfología, relaciones estructurales, cánones estéticos utilizados, combinaciones y variaciones, establecer los elementos que aparecen repetidamente como constantes formales a fin de dejar establecidos ciertos lineamientos directrices que conducen hacia el camino de simplificar la experiencia visual. Para lograr estos objetivos se hará uso de una metodología basada en los estudios del formalismo, estructuralismo, Gestalt y los relacionados con las bases del diseño y el estudio de la imagen.

Los aportes que hacia la mitad del siglo XX realiza el Estructuralismo, sobre la base del modelo de la Lingüistica y la Semántica, ayudaron a encontrar el lazo necesario entre la forma (el significante) y su sentido (el significado). En otras palabras, la imagen se compone de forma y contenido.

Por otra parte, las teorías de la Gestalt acerca de la percepción sirven como apoyo evidente al modelo de análisis estructural. Lo importante es conseguir la comprensión visual de las formas y figuras representadas. Cada una, y en su conjunto, constituyen el todo, pero es necesario identificar sus partes, pues dependen y son parte de la totalidad de la obra. Se complementan y no pueden existir independientemente dentro de la percepción. En este análisis se parte de este concepto, 
identificando las partes simples que constituyen las unidades visuales mínimas en la arquitectura-escultura para después entender sus relaciones dentro de una estructura geométrica, morfológica y funcional con cualidades visuales. A través de la realización de dibujos lineales de las fachadas principales de los edificios casos de estudio se puede apreciar mejor la forma y composición. Estos servirán para una más clara visualización y captación de los elementos constitutivos.

A través de este ordenamiento metodológico y con los objetivos planteados inicialmente se pretende aportar más conocimientos y reflexiones en esta área de investigación que permitan un mayor acercamiento a este patrimonio para su valoración, difusión y conservación.

\section{ANTECEDENTES Y JUSTIFICACION DEL TEMA.}

La ciudad arqueológica de El Tajin, ubicada en la región norte del estado de Veracruz, México, está considerada una de las más importantes del México antiguo. Está conformada por 168 edificios de carácter público, 27 templos, 17 canchas para el Juego de Pelota, algunas con elaborados bajorrelieves, 58 residencias, tres altares y 46 casas-habitación identificadas, hasta el momento. Se considera explorado sólo un $10 \%$ del sitio.

A partir del año 1924, hasta la fecha, se han llevado a cabo, de manera continuada, trabajos de investigación de diversa 
índole, todos encaminados hacia la conservación y consolidación de sus edificios, templos y palacios.

Las investigaciones que están relacionadas con aspectos de carácter formal y estético en El Tajín han sido principalmente las de Tatiana Proskouriakoff (1951), quien realiza los primeros estudios sobre los bajorrelieves escultóricos, encontrando, en su forma de representación y diseño, un estilo particular en base a cierto patrón de repetición de elementos denominados volutas o ganchos entrelazados intercalados, con formas zoomorfas y grotescas al que nombra “estilo Tajín” o "estilo Clásico veracruzano" ya que aparece en toda la zona del Estado de Veracruz durante el período Clásico mesoamericano. Proskouriakoff considera que el "estilo Clásico de Veracruz" es similar al de las tierras bajas mayas, pues ambos son primariamente gráficos y su desarrollo conlleva a la elaboración de volutas y figuras grotescas; contrastando con la representación de la figura humana cargada de un fuerte naturalismo. Ambos estilos muestran preocupación por la belleza, regularidad de formas, y gusto por el ornamento. (Proskouriakoff, 1971: 558-559).

Michael Edwin Kampen, quien en su tesis The scultures of el Tajín Veracruz, México (1972), realiza estudios sobre los bajorrelieves de los Juegos de Pelota Norte y Sur y concluye básicamente que: el relieve tiene dos planos superpuestos, donde la línea es el recurso artístico para la representación de las figuras; se utilizan patrones de encuadre geométricos determinados por la arquitectura, se mezclan las formas 
humanas con las volutas; la voluta es la forma decorativa básica e identifica los motivos gráficos más representados y su patrón de representación.

Colaboradora durante el Proyecto Tajin, encabezado por Jüergen K. Brüeggemann, Patricia Joan Sarro realiza su tesis doctoral sobre la arquitectura-escultura de El Tajín Chico. Relaciona los elementos escultóricos de los edificios con el espacio y la estructura arquitectónica tratando de interpretar un mensaje en ellos. El nicho, la greca escalonada, los rombos entrecruzados, la cruz y forma de $\mathrm{T}$ son los motivos gráficos que estudia con sus variantes y combinaciones, otorgándoles una interpretación iconográfica e iconológica.

Román Piña Chan y Patricia Castillo publican el libro: "Tajín, la ciudad del Dios Huracán” en el cual hacen una descripción de todos los edificios del sitio a través de un recorrido histórico de acuerdo a las tres fases de desarrollo de la ciudad. Describe cada uno de los 12 tableros de los Juegos de Pelota Norte y Sur y aporta su interpretación iconológica. Habla de Quetzalcoatl como la deidad principal y de sus diferentes advocaciones encontradas tanto en elementos escultóricos como arquitectónicos.

Sobre el arte del Tajín mencionan que la mayor parte de las representaciones artísticas corresponden a un arte mayor ya que se encuentran integradas a la arquitectura en tres categorias: templos, palacios y juegos de pelota. 
Así como el urbanismo tuvo tres fases de desarrollo, también lo tuvo el estilo plástico plasmado en los frisos y tableros. A través de dibujos lineales muestra tal desarrollo, que es sencillo al inicio, y de gran refinamiento y detalle al final, cuyos ejemplos más importantes son los bajorrelieves provenientes de las columnas del Edificio 42.

Tal como se dice en su libro, las escenas de los tableros son por cuadretes y, también, que la representación es de estilo simbólico-realista con líneas curvas que representan todo tipo de movimiento: el viento, el agua, las plantas, los animales, los hombres, hasta llegar a mostrar el concepto dual que se manifiesta en la perspectiva del diseño, creando dobles representaciones unidas por el centro, que se pueden observar desde cualquier ángulo siendo su estilo el abstracto.

En la última fase, además del estilo detallado y de excelente acabado en el relieve, la composición se presenta casi sin espacios vacios siendo uno de los signos más representados el de ollin o movimiento.

La publicación "Imagen y Pensamiento de El Tajin" de S. Ladrón de Guevara menciona de manera general algunos aspectos formales: de los bajorrelieves del Juego de Pelota afirma que las figuras se trabajan planas, los formatos son generalmente cuadrangulares, la composición es clara, bidimensional, sin efectos de profundidad ni de perspectiva y casi sin espacios vacíos. La línea inferior del bloque es el piso de la escena. 
Reconoce, asimismo, que el Estilo Tajin se puede apreciar como una unidad en la arquitectura, escultura, pintura mural y urbanismo de El Tajín y que los relieves y las pinturas en El Tajin son importantes documentos gráficos. Sobre las columnas realiza una propuesta de lectura y seguimiento de las escenas y estudia las diferentes posturas de la figura humana y su importancia en el arte del sitio. También analiza la pintura mural y añade al final un recorrido sobre las principales investigaciones realizadas en El Tajin, que han orientado el presente trabajo.

Arturo Pascual Soto ha realizado varias publicaciones, entre ellas "Iconografía Arqueológica del Tajín" en la cual propone que las imágenes escultóricas pueden formar parte de signos $o$ lexemas dentro de un sistema codificado de comunicación y los cambios formales son importantes para identificarlo. Su trabajo es una propuesta novedosa que abre nuevas perspectivas en este campo.

Las investigaciones anteriores han arrojado importante información indispensable para poder comprender y saber apreciar los elementos artísticos y estéticos; sin embargo es necesario seguir profundizando en este campo de estudio. El análisis del lenguaje visual de la arquitectura-escultura pretende contribuir en esta área, identificando constantes formales dentro de una morfología estructural cuyas soluciones visuales finales determinan un lenguaje no verbal. 
Este representa un invaluable documento artístico tangible y de más de 1700 años de supervivencia.

Finalmente, todos estos esfuerzos tienen un mismo propósito: la conservación y difusión de un patrimonio cultural universal.

\section{OBJETIVOS Y METODOLOGIA DE LA INVESTIGACION}

- Mencionar las características generales de iconografia, formato y simbología de elementos escultóricos encontrados en la zona Centro-Norte del Estado de Veracruz como antecedente del lenguaje visual desarrollado en El Tajín.

- Reconocer la existencia de un "pensamiento visual" que antecede a la obra artística de El Tajín, que está perfectamente reconocido y organizado de acuerdo a convenciones ideológicas, sociales, religiosas y estéticas.

- Identificar los elementos formales indivisibles que constituyen las unidades mínimas de la estructura compositiva del lenguaje visual de la arquitectura-escultura de El Tajín.

- A través de casos de estudio, identificar las constantes formales de la arquitectura-escultura de El Tajín realizando tablas explicativas.

- Mencionar las cualidades visuales derivadas de la experiencia visual basada en las leyes de la Gestalt. 
- Ampliar y profundizar en el conocimiento de la plástica y cánones estéticos empleados en la representación arquitectónica-escultórica más sobresaliente de El Tajín.

- Aportar conocimientos para la interpretación iconográfica e iconológica de la arquitectura-escultura de El Tajín.

- Con todo lo anterior reconocer, difundir y conservar las formas de ver y reconocer en las soluciones formales derivadas del lenguaje visual, el legado artístico mesoamericano dentro de la historia universal.

\section{METODOLOGIA}

- Consulta y acopio de la mayor información fotográfica y de dibujos publicados sobre el tema.

- Revisión bibliográfica sobre la zona arqueológica de El Tajín y temas relacionados con la investigación.

- Toma de fotografias y detalles escultóricos in situ.

- Para lograr los objetivos del análisis se emplearán los principios $\mathrm{y}$ formulaciones de las corrientes formalista $\mathrm{y}$ estructuralista de la historia del arte.

- A través de los estudios de percepción de la forma de la Gestalt realizar propuestas de lectura formal de cualidades visuales propias.

- Realizar dibujos lineales de edificios y detalles arquitectónicos- escultóricos como apoyo gráfico para las ideas expuestas. 


\section{CAPITULO 1. EL CONTEXTO PREHISPÁNICO}

\section{MESOAMÉRICA}

\subsection{Concepto y ubicación geográfica de Mesoamérica}

El nombre de Mesoamérica fue acuñado por vez primera por el investigador Paul Kirchhoff en 1943. Su propuesta es la que rige hasta nuestros días y reúne lo unitario y lo diverso que encierra el concepto. Los límites geográficos que estableció para la región fueron: al norte, los ríos Sinaloa en el Pacífico y Pánuco en el Atlántico, de México; al sur, la región noroccidental de Costa Rica; al este, la zona central de Honduras y parte de Nicaragua y, al oeste, Guatemala y E1 Salvador.

Fig. 1. Mapa de Mesoamérica y sus áreas culturales.

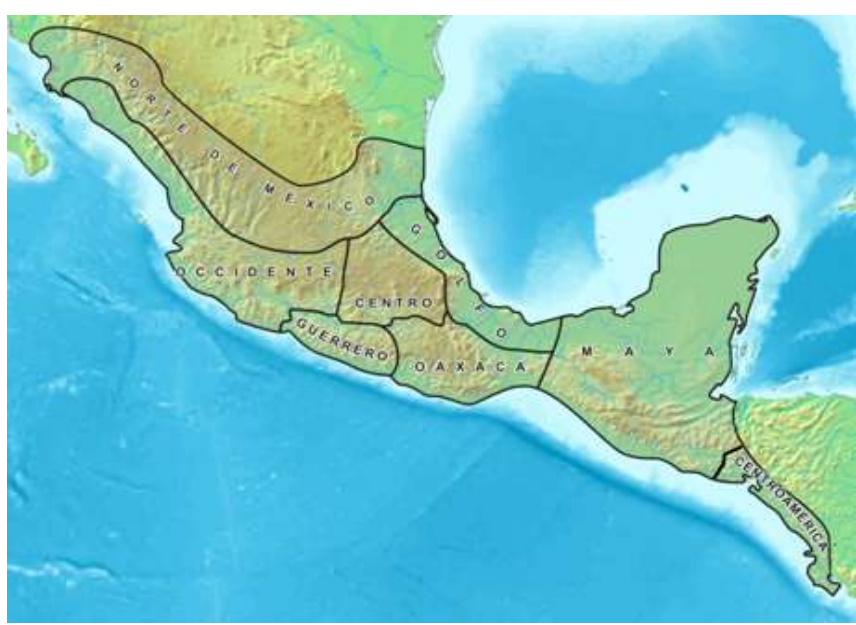

Fuente: ancient-mesoamerica-news-updates.blogspot.com... 
Se trata de una macroregión cultural de gran diversidad étnica y lingüística, (llegó a tener una población de más de 50 millones de personas).

De acuerdo a Kirchhoff, en Mesoamérica destacan varios rasgos importantes y distintivos siendo algunos de ellos: construcción de pirámides escalonadas, escritura jeroglífica, el uso de los códices o libros plegados, dos calendarios: el año de 18 meses de 20 días más cinco días adicionales (365 dias), y la combinación de 20 signos y 13 números para formar un período de 260 dias, estos dos daban el siglo mesoamericano de 52 años, cultivo del cacao y del maíz, el uso del cero y numeración a base de símbolos, etc. ${ }^{2}$

Cultivo del cacao: (kakaw, lengua maya)

Fig. 2.Escena mitológica con árbol de cacao. Vaso de cerámica, cultura maya, modelada y pintada. Altiplano norte, período clásico tardío (600-900 DC).

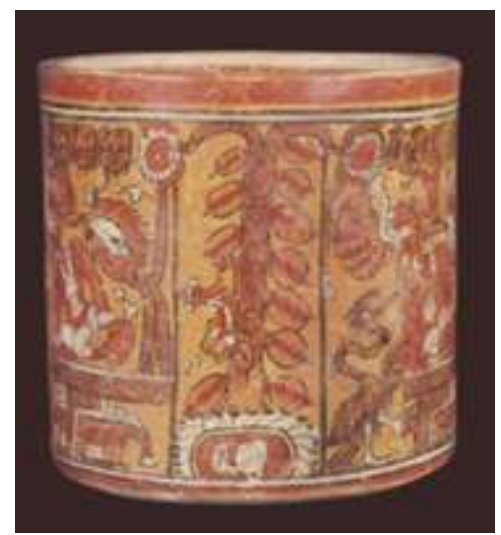

Fuente: www.popolvuh.ufm.edu.gt/Kakaw00.htm

\footnotetext{
${ }^{2}$ Matos Moctezuma, Eduardo, Mesoamérica Antigua.

En www.seacex.es/documentos/america_mestiza_10_meso.pdf.
} 


\section{2 Áreas culturales}

Se ha dividido para su estudio el espacio geográfico de Mesoamérica en las que se conocen como áreas culturales, teniendo en cuenta su ubicación geográfica y las civilizaciones que se han originado en cada una de ellas en diferentes períodos históricos:

1. Centro de México (Altiplano Central): Cultura Teotihuacana y Cultura azteca.

2. Valles de Oaxaca: Zapotecos y Mixtecos.

3. Costa del Golfo: Olmecas y civilización de El Tajín.

4. Área maya.

5. Occidente y Norte de México.

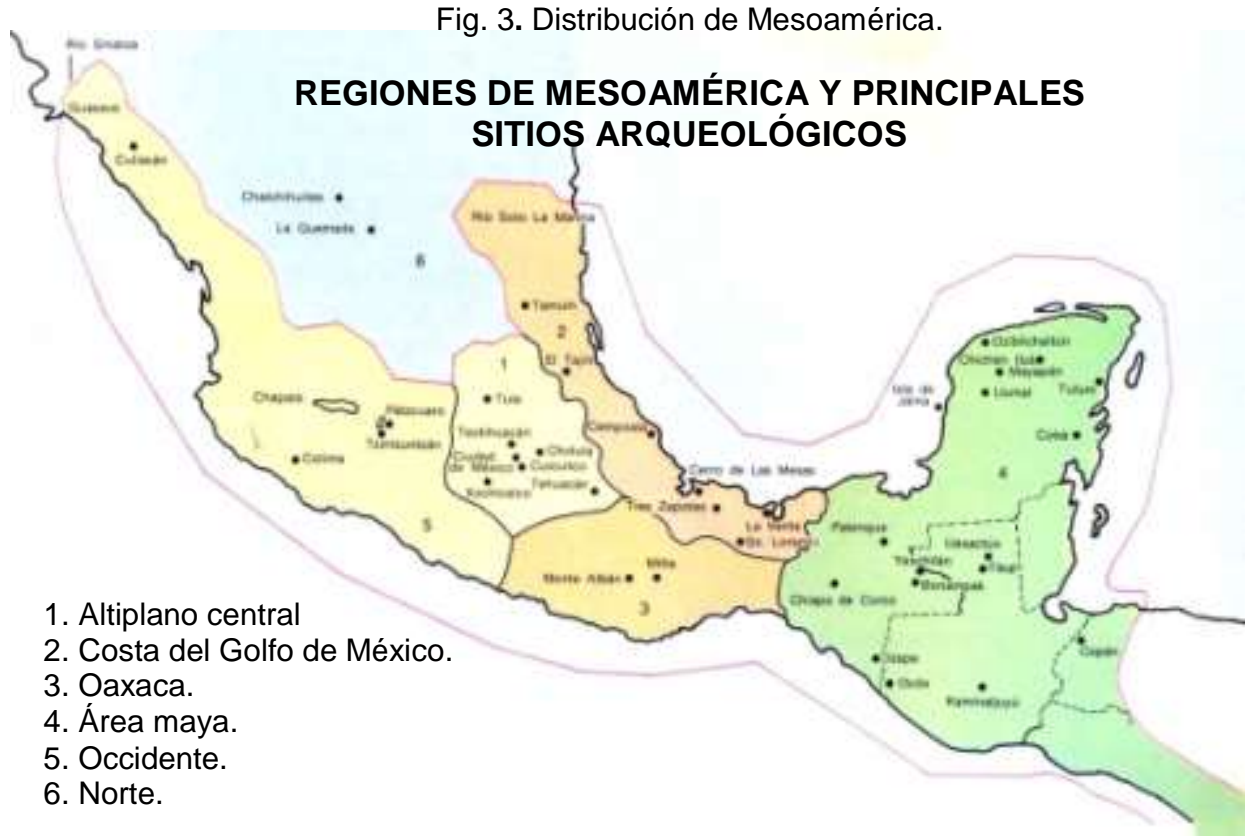

Fuente: Enciclopedia "México y su Historia" 


\subsection{Periodos históricos}

En Mesoamérica, recién se ha podido establecer una periodificación aceptada por la mayoría de los estudiosos hacia mediados del siglo XX, que divide la historia de esta macroregión en tres grandes periodos: Preclásico, Clásico y Posclásico. Las fechas de estos períodos son aproximadas, ya que cada una de las regiones que constituyen Mesoamérica y cada uno de sus pueblos tuvo una historia particular cuyos procesos específicos dificilmente podrían ser captados por una cronología, que es sólo un modelo interpretativo para fines prácticos.

Siguiendo a López Austin y López Luján³ en su periodificación, podemos destacar las características sobresalientes de cada etapa a continuación:

\section{Preclásico (2500 a.C. - 150 / 200 a.C.)}

a. Temprano (2500 a.C.-1200 a.C.): Empiezan el sedentarismo agrícola y la producción de cerámica en asentamientos en aldeas de no más de 20 chozas. Los grupos humanos se hacen homogéneos y van ampliando su base puramente familiar, con una organización tribal igualitaria. Los bienes de subsistencia eran de producción interna, aunque había algunos

\footnotetext{
${ }^{3}$ López Austin, Alfredo y López Luján, Leonardo, Tiempo Mesoamericano, en Arqueología mexicana, Ed. especial Núm.11, Editorial Raíces, México, 2002. P. 11 a 13 .
} 
intercambios entre aldeas. Primeros indicios de prácticas religiosas referidos a ritos fúnebres.

b. Medio (1200 a.C.-400 a.C.): La agricultura experimenta grandes. Empieza la especialización de la producción, y se refina la manufactura de bienes de prestigio. Diferenciación y jerarquización entre aldeas por su tamaño, y en la sociedad por linajes. Aumenta el intercambio de productos. Surgen el calendario y la escritura, y avanzan el urbanismo y la arquitectura con la construcción de plazas y templos sobre plataformas. Predomina en Mesoamérica el fenómeno olmeca.

c. Tardio (400 a.C.-150/200 d.C.): Se da en algunas regiones el crecimiento rápido de la población y la agricultura intensiva. La complejidad de las sociedades promueve el desarrollo de formas de organización más sofisticadas. Surgen grandes capitales con aldeas satélite. Largas rutas de comercios. Rivalidad politico-militar entre grandes ciudades. Se desarrolla la arquitectura monumental.

\section{Clásico (150 / 200 d.C. - 900 d.C.):}
a. Temprano
$(150 / 200$
d.C. -650
d.C.):

Diferenciación entre las zonas urbanas y las 
rurales. Especialización laboral. Diferenciación social acentuada. Las elites ostentan el gobierno, con la incorporación, además, de la casta religiosa. Las capitales se transforman en potencias político-militares, lo que genera en esta fase la aparición de los primeros grandes estados mesoamericanos. Redes complejas de comercio. Guerras de expansión territorial y control. Sacrificios humanos. Urbanismo planificado con rigor. Predominio en Mesoamérica de lo teotihuacano.

b. Tardio (650 d.C.-900 d.C.): La caída de los grandes estados mesoamericanos da aire a los antiguos tributarios para convertirse en poderosas unidades políticas regionales, que sucesivamente hallan su auge y su colapso. Se fraccionan las redes de comercio. Se produce un impresionante desarrollo económico, cultural y artístico en el oriente mesoamericano. Arquitectura y urbanismo defensivos. Marcada pluralidad étnica en las sociedades de la zona. Eclecticismo artístico. E1 calendario, la numeración, la escritura y la astronomía llegan a sus niveles de desarrollo más altos.

\section{Posclásico (900 d.C. - 1520 d.C.)}

a. Temprano (900 d.C.-1200 d.C.): Se retrae el límite norte de Mesoamérica. Penetran en el 
territorio pueblos septentrionales. Movilidad de grupos humanos. Amplia difusión de elementos culturales. Gran inestabilidad política. Auge del culto religioso a la Serpiente Emplumada. Arte bélico y con referencias a la muerte. Grandes rutas comerciales. Se desarrolla la metalurgia.

b. Tardio (1200 d.C.-1520 d.C.): Estados agresivos y expansionistas surgen y caen repentinamente. Los vencidos rinden tributo a sus conquistadores. Se intensifican el militarismo y los sacrificios humanos. Gran parte del territorio mesoamericano es dominado por la Triple Alianza. Invasión europea que da fin a la historia de Mesoamérica, con la conquista paulatina del territorio y el inicio de la vida colonial.

Fig. 4. Periodización de Mesoamérica en el contexto de la historia de México.

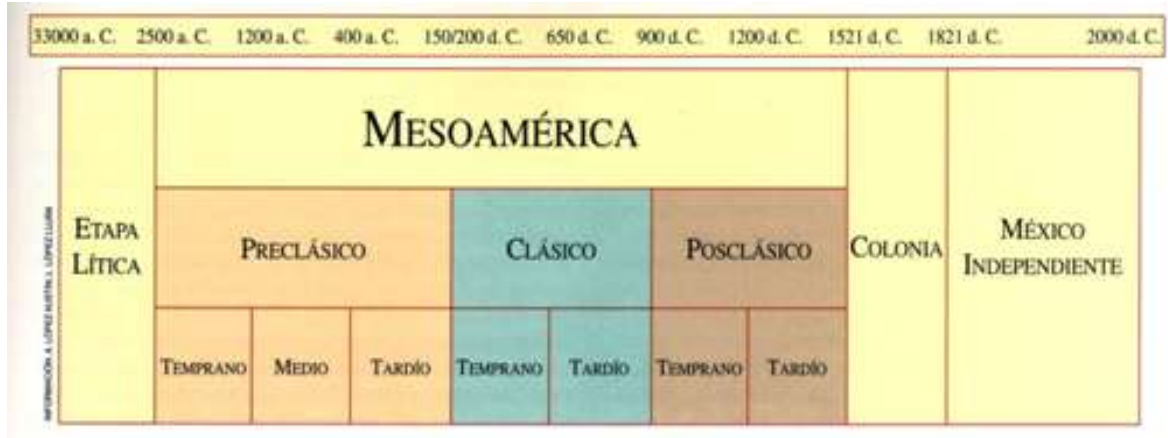

Fuente: Arqueología Mexicana, Edición Especial Núm. 11, pág. 7 


\subsection{Características de la civilización de Mesoamérica.}

Es dificil resumir en pocos ejes la riqueza de la civilización mesoamericana. Se ha optado en aquellas particularidades significativas que sirvan para entender la concepción subyacente que inspiró las obras artísticas que forman parte del patrimonio de Mesoamérica. El pensamiento mítico es el eslabón fundamental de esta cadena: el mito, la magia y la religión darán forma a los dioses y les atribuirán un papel y una jerarquía en su incidencia sobre la realidad; el orden celeste y el terreno hallarán su confluencia y su destino en los calendarios; el maíz será adorado como sustento diario y necesario de los hombres; el Juego de pelota será la analogía del universo y su constante lucha. Todos estos elementos han de conducir para esbozar en el último punto de este apartado las señas de identidad que tipifican al arte prehispánico en la región.

\subsubsection{Mito, magia y religión.}

Paul Westheim señala específicamente el papel del mito en Mesoamérica:

El mito es para el hombre de México prehispánico la realidad que forma e informa su vida, su pensamiento, su fe, su conciencia y también su subconsciente. 
Gracias al mito comprende el cosmos y su propia posición en él. En el mito descubre el sentido y significado de su circunstancia terrestre y de sus vivencias metafisicas entre los cuales, para su modo de pensar, no hay limite ni diferencia: no distingue entre los fenómenos sensibles y los suprasensibles. El mito es una fuerza más vigorosa y arraigada en estratos más profundos que la razón. Para el hombre que no adquiere sus conocimientos mediante procesos de abstracción, el mito es la ciencia que lo pone en condiciones de resolver sus problemas vitales a su propia manera, es decir, de acuerdo con sus representaciones ${ }^{4}$.

Para los pueblos de esta región, el mito no es un dominio al margen de la vida; no es la satisfacción de necesidades metafisicas, posterior o simultánea a la satisfacción de las necesidades materiales: abarca la totalidad de la vida, tanto la religiosa como la profana, que de todos modos está religiosamente determinada.

La realidad se entendía como dividida en distintos planos: 9 en el cielo ("los que están sobre nosotros"), 9 en el inframundo ("los nueve de la región de la muerte") y 4 pisos en el medio donde está el mundo de lo humano, tiempo-espacio creado

\footnotetext{
${ }^{4}$ Westheim, Paul, Ideas fundamentales del arte prehispánico en México. Alianza Editorial, Madrid, 1987, p.19-20
} 
como casa de los seres mundanos. Lo Alto y lo Bajo se comunican por cinco columnas o cinco árboles que están emplazados uno en el eje central y los demás en los cuatro extremos del cosmos. También hay bocas (umbrales) por los que pasa la divinidad, las almas de los muertos, etc. (generalmente, cuevas y cenotes). Hay, por supuesto, barreras entre los planos, establecidas por los dioses. En el plano divino se guardan las semillas-corazones de los hombres y se las envía desde alli al mundo. Por ello los mesoamericanos pensaban que en el corazón se encontraba la partícula divina de cada criatura y ofrecian a los dioses esta parte de la anatomía en el sacrificio ritual.

Fig. 5. División de los 22 pisos del cosmos, de los cuales los nueve más altos y los nueve más profundos corresponden al ámbito divino, mientras que la superficie de la tierra y los cuatro cielos inferiores forman la casa de las criaturas, gobernada por el Sol.

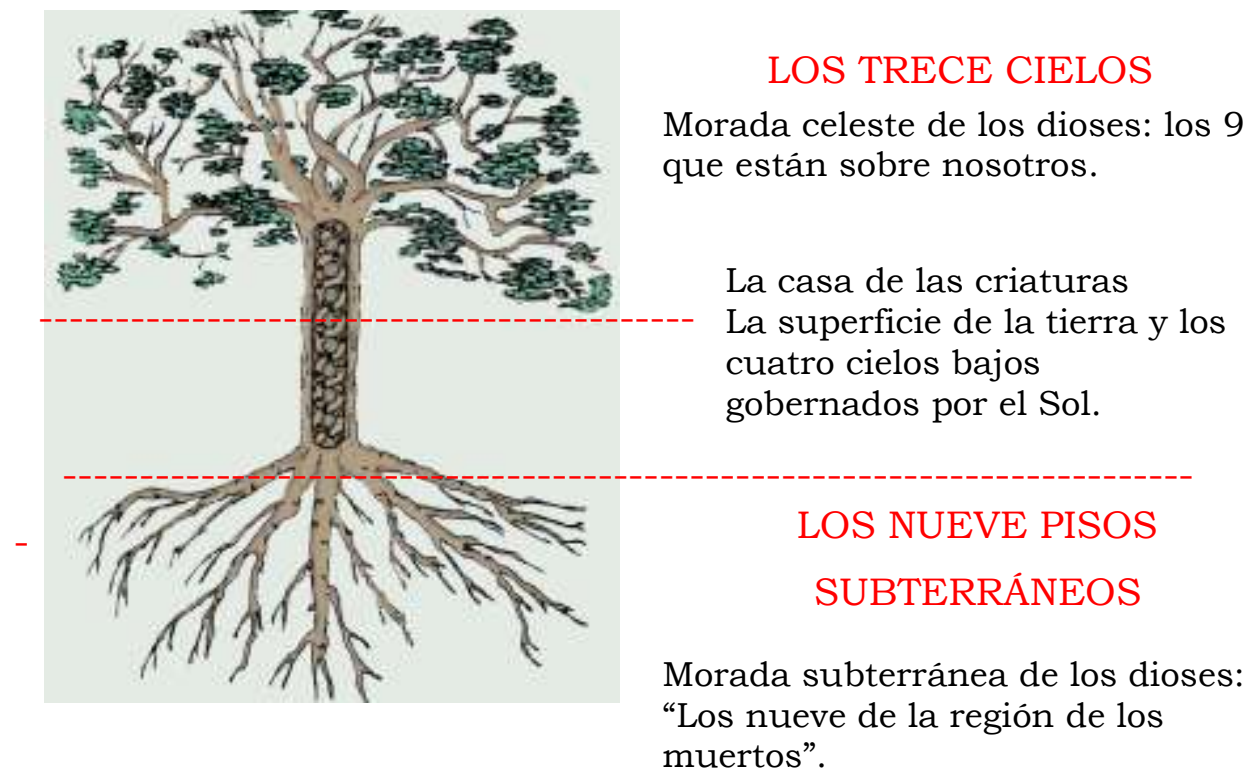

Fuente: www.arqueomex.com 
La magia la manejaban, tanto personas comunes como expertos poseedores de profundos conocimientos y terribles poderes otorgados por los dioses. Destacan los llamados nahuales que tenían la facultad de tomar la forma de un animal (puma, jaguar, perro, lechuza, serpiente...) y que era utilizada tanto por seres humanos como por los dioses, para interactuar con los humanos; así por ejemplo el dios azteca Huitzilopochtli era un colibrí, Tezcatlipoca coyote o jaguar, Quetzalcoatl, pájaro-serpiente, etc. ${ }^{5}$

Con la adivinación se buscaba conocer lo desconocido haciendo uso de su componente divino, y para ejercerla, se requería tener semejanza con los dioses viejos Oxomoco $y$ Cipactónatl, expertos en artes adivinatorias que fueron usados por los nahuas como modelo humano. Con la adivinación se quería saber acerca del futuro, el pasado distante y el presente oculto: la ubicación de una persona, el origen de las enfermedades, el tratamiento adecuado de los pacientes, la suerte de los enfermos, el clima futuro, la suerte de las batallas, las calamidades que se ciernen sobre la población, el destino de las empresas, etc. En Mesoamérica se practicaba, a través del lanzamiento de granos de maíz, la interpretación de los libros sagrados (lectura de los códices calendáricos), etc. Existen dos tipos de mitos en Mesoamérica: los generales, que se encuentran casi literalmente en todas o en muchas de las

\footnotetext{
${ }^{5}$ La interpretación popular explica que, según la tradición, cada persona al nacer ya tiene el espíritu de un animal que se encarga de protegerla y guiarla a través de los sueños tomando forma de espíritus llamados nahuales. Éste término es de origen nahuatl y se dió solo en México, equivalente al chamán o chamanismo de Europa.
} 
Fig. 6. Oxomoco y Cipactónal, los dos ancianos considerados arquetipos de la división sexual de los seres humanos, tienen también capacidad de enfrentarse a los poderes sobrenaturales. En estas representaciones portan bolsas sacerdotales, punzones para trazar los días de los destinos, un tlémaitl (incensador de mano) o arrojan granos de maíz con fines adivinatorios.

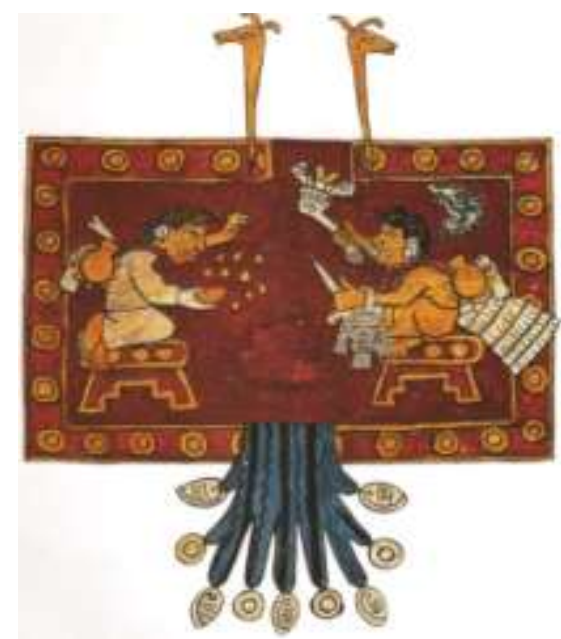

Fuente: Códice Borbónico, lám. 21. en Arqueología Mexicana Núm. 34.

sub-áreas culturales (caso del mito del descubrimiento del maíz: grano guardado por las hormigas en un monte y que, gracias a un rayo que parte la montaña, el hombre pudo acceder a él) y los particulares que se presentan en modo distinto en diferentes lugares de Mesoamérica (caso de la creación del hombre, que varía bastante según cada cultura). El principio creador es siempre dual, por lo general simbolizado por una pareja de dos ancianos: los nahuas los llamaban Ometéotl, dios de la dualidad: Ometecuhtli, señor dual, Omecíhuatl, señora dual; los mayas yucatecos, Ixchel, "la que yace", e Itzamná, "casa de la iguana"; los quichés, Alom, Q'ahalom, "el que engendra", la que concibe". De este doble principio masculino y femenino, provienen, por generación, los demás dioses: Ometecuhtli (2 Señor) y Omecíhuatl (2 Señora), 
eran representados con símbolos de fertilidad y adornados con mazorcas de maíz, pues son el origen de la generación y los señores de la vida y los alimentos. Tuvieron cuatro hijos a los que encomendaron la creación de los otros dioses, del mundo y de los hombres. Los cuatro dioses hijos de la primitiva pareja divina fueron el Tezcatlipoca rojo, llamado también Xipe y Camaxtle; el Tezcatlipoca negro, llamado comúnmente Tezcatlipoca, Quetzalcoatl, dios del aire y de la vida, y Huitzilopochtli, el Tezcatlipoca azul.

Una de las ideas fundamentales de la religión azteca consiste en agrupar a todos los seres según los puntos cardinales y la dirección central, o de abajo arriba. Por eso en la mentalidad mexicana son tan importantes los números 4 y 5 , como en la mentalidad mágica occidental es importante el número 3.

Los cuatro hijos de la pareja divina (que representa la dirección central, arriba y abajo, es decir, el cielo y la tierra) son los regentes de las cuatro direcciones o puntos cardinales; por eso vemos que tres de ellos se nos presentan con colores diferentes: rojo, negro y azul, que corresponden al este, al norte y al sur, mientras que Quetzalcoatl está quizás en el lugar que debió tener en el mito primitivo un 
Tezcatlipoca blanco, que correspondía al oeste (...).

Esta idea fundamental de los cuatro puntos cardinales y de la región central (abajo arriba), que da la quinta región o sea la región central, se encuentra en todas las manifestaciones religiosas del pueblo azteca y es uno de los conceptos que sin duda este pueblo recibió de las viejas culturas de Mesoamérica 6 .

No sólo los colores y los dioses quedan agrupados en esta forma; también los animales, los árboles, los días y los hombres, por el día en que nacen, pertenecen a una de las cuatro regiones del mundo, pues el hombre recibe el mismo nombre del día en que nace, dentro del calendario ritual de 260 días.

También en los relatos míticos mesoamericanos es muy frecuente encontrar sucesivas creaciones y destrucciones de

Fig. 7. Primera página del códice Fejérváry-Mayer con los cuatro rumbos del universo.

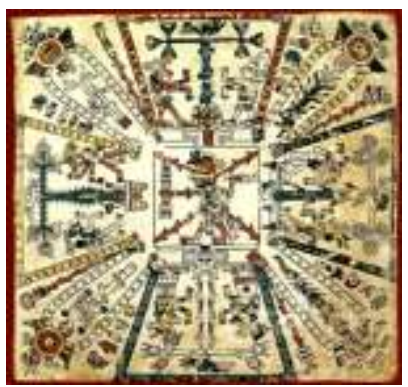

Fuente: www.famsi.org

${ }^{6}$ Caso, Alfonso, El pueblo de Sol. Fondo de Cultura Económica, México, 1974, pp. 21-22. 
los hombres, lo que muestra, como constante, la idea de evolución.

En esta idea de las múltiples creaciones, además de ese sentimiento de ensayo divino, que los dioses destruyen por imperfecto, subyace la idea de que los mundos que se van creando se van acercando a la perfección ${ }^{7}$. Otra idea central que se desprende de esta serie de creaciones y destrucciones es la de que los dioses exigen un culto constante, y que la creación no es un don gracioso hecho al hombre por el dios, sino un compromiso que implica la obligación de una continuada adoración.

El mito de la Quinta Era cuenta que el Sol se destruyó con la última hecatombe, y los dioses se reunieron en Teotihuacan y determinaron que uno de ellos se sacrificara y se convirtiera en Sol.

Otros mitos importantes en Mesoamérica son los referidos al tiempo, a la cultura y el poder. Como se verá más adelante, más allá de algunas diferencias, todos los pueblos mesoamericanos cuentan con un sistema calendárico semejante. Para los nahuas el calendario tiene un origen divino: el tonalpohualli, "cuenta de los destinos", había sido inventado por Oxomoco y Cipactónal; el xíhuitl o "cuenta del año solar" era don de Quetzalcoatl. Para los mayas el calendario era invento de Itzamná.

\footnotetext{
${ }^{7}$ Todo esto es muy patente en el Popol Vuh.
} 
En todo el ámbito mesoamericano el tiempo, computado con extremado rigor en función de sus sistemas calendáricos, se concibe como portador de presencias de dioses y de destinos favorables, funestos o indiferentes. Ello es, desde luego, mucho más patente entre los mayas, quienes concebían su universo poblado de presencias de dioses actuantes en los distintos rumbos cósmicos y en las regiones celestes e inferiores. Esa ininterrumpida actuación de los dioses no ocurre al azar, sino con precisión matemática expresada por los cómputos calendáricos. Las inscripciones cronológicas de los mayas implican el conocimiento y la adoración de los ciclos del tiempo, los cuales marcan, a su vez, los grandes capítulos en la que se concibe como una historia cósmica cuya esencia es el tiempo ${ }^{8}$.

Lo que se llama cultura, y también el del gobierno o poder, fueron asimismo objeto de relatos fundacionales. La cultura que para los pueblos nahuas no es otra cosa que la toltecáyotl, el conjunto de las creaciones toltecas, se atribuía a Quetzalcoatl. ${ }^{9}$

\footnotetext{
${ }^{8}$ León Portilla, Miguel, Mitos de los orígenes en Mesoamérica. En: Arqueología mexicana, núm. 56, Vol. X. México, Editorial Raíces, 2002, pp. 20-27. Ver apartado 1.4.3 del presente capítulo.

9 Para más información sobre Quetzalcoatl y otras divinidades, consultar el punto siguiente.
} 


\subsubsection{Quetzalcoatl, deidad suprema de Mesoamérica, y otras deidades.}

Además de la estructura de pensamiento mítico esbozada en el punto anterior, las culturas mesoamericanas atribuyeron un gran protagonismo a sus deidades en la vida cotidiana. A la llegada de los europeos, fue grande su sorpresa al notar el lugar prominente que la cultura azteca le asignaba a lo divino, al punto que la marcha misma del cosmos era asunto de Estado y responsabilidad de los hombres y sus soberanos.

La destrucción de muchos documentos por parte de los españoles, sumado a que las crónicas aztecas no se detenían especialmente sobre los períodos históricos anteriores a su propia cultura, hacen que la mayoria de las fuentes confiables disponibles den información de sucesos ocurridos a partir del siglo $\mathrm{X}$ de la era cristiana en adelante, y refieran a la historia de la parte central de México.

$\mathrm{Si}$ bien no emplearon más que los rudimentos de escritura fonética, los antiguos mexicanos poseían verdaderos archivos concernientes a su pasado: libros en cuero o en papel (obtenido de cortezas de plantas), en cuyas páginas, plegadas a la manera de un biombo, los acontecimientos están consignados por medio de figuras simbólicas y de fechas. Son éstos, los libros pintados, los que sirvieron de base a los 
anales redactados después de la Conquista y, por ser traducción literal de imágenes, la historia precolombina se singulariza por un laconismo que desorienta, pues los hechos aparecen secos y escuetos, desprovistos de todo contexto ${ }^{10}$.

Fig. 8. Serpiente emplumada. Cultura mexica. Posclásico tardío.

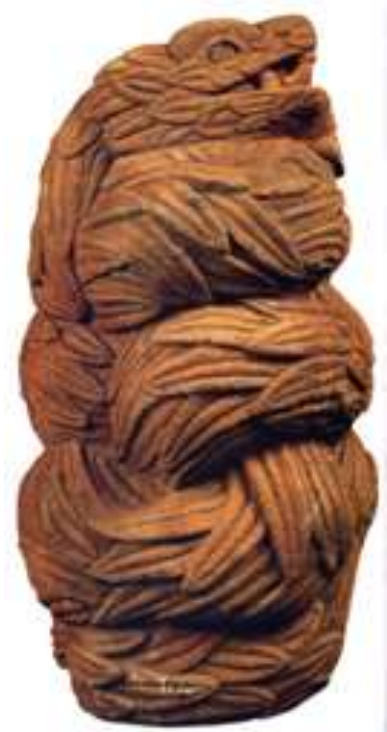

Fuente: Arqueología Mexicana, Vol. IX, Núm. 53, pag. 28

El culto de Quetzalcoatl les llega a los aztecas, como tantas otras cosas, por vía de la influencia tolteca. Su mito puede resumirse en pocos pero significativos hechos: Quetzalcoatl era un rey muy casto y puro hasta el día en que, impulsado por malos consejeros, se embriaga y comete el pecado de

\footnotetext{
${ }^{10}$ Séjourné, Laurette, El universo de Quetzalcoatl. FCE, México, 2003, pp. 9-10.
} 
dormir con la bella Xochipétatl. Se castiga a él mismo abandonando su reino de Tula y encendiendo la hoguera de la cual su corazón, liberado por las llamas, se elevará al cielo transformado en el planeta Venus. Esta transformación tendrá lugar después de una visita al Señor del mundo subterráneo, al que arrancará los restos de sus padres, y con los huesos de generaciones pasadas y su sangre creará la humanidad. No solo creó a los hombres, sino que les entregó el maíz, robado a las hormigas, y les enseñó las artes y la ciencia: medir el tiempo y estudiar las revoluciones de los astros: les enseñó el calendario e inventó las ceremonias y fijó los dias para las oraciones y los sacrificios.

Sus símbolos son el pájaro, que simboliza el cielo (el águila representa al sol, el colibrí tanto al sol en su nacimiento como al alma que se eleva sobre la tierra) y la serpiente, que simboliza a la materia y es asociada con las divinidades femeninas de la Tierra y el agua. Entre las culturas mesoamericanas, la materia es sinónimo de finitud, muerte y nada. Cráneos y serpientes, por ello se suelen encontrar juntos. Pero lo que representa la serpiente es el movimiento: no se trata de representar a la materia inerte y acabada, sino más bien su función generadora y dinámica.

Desde el Preclásico olmeca (1150-500 a.C.) se encuentran representaciones de diversas serpientes con características de ave: pico o crestas aladas y emplumadas. En la ciudad sagrada de Teotihuacan, en cambio, la serpiente emplumada es una criatura con características particulares: tiene forma de 
serpiente de cascabel y largas plumas de quetzal macho, ave procedente de Chiapas y Guatemala, en las Tierras Altas mayas. Esta criatura de Teotihuacan es el antecedente inmediato de la serpiente emplumada tal y como se le conoce entre culturas posteriores como Cacaxtla, Xochicalco y los toltecas y aztecas del Posclásico ${ }^{11}$.

Fig. 9. Talud y tablero del Templo de Quetzalcoatl, Teotihuacan.

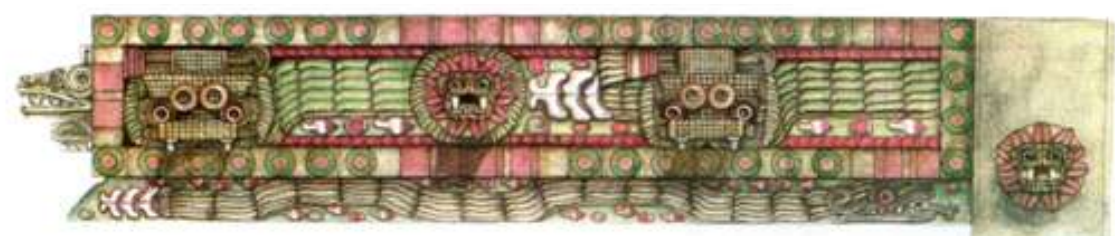

Fuente:José Villaseñor en Arqueología Mexicana, Vol. IX, Núm. 53, pág. 34

La serpiente emplumada representa una hibridación de especies que a priori parecen antagónicas: la pesada materia que se arrastra por el suelo y la sustancia alada que aspira siempre a la altura.

Quetzalcoatl es un dios antiquísimo que presenta, en los relatos, un problema de dualidad histórico-mítica entre la figura del rey de Tula y la del dios. Entre los mayas fue conocido como Kukulcán, y entre los quichés como Gucumatz, además del antecedente de la serpiente emplumada que hemos visto en Teotihuacan. Se dice que en su penitencia parte hacia el mítico Tlillan Tlapallan, "la tierra del negro y del rojo", y promete volver por el Oriente en el año de su nombre, Ce Ácatl.

\footnotetext{
${ }^{11}$ Taube, Karl, La serpiente emplumada en Teotihuacan. En: Arqueología mexicana, núm. 53, Vol. IX, Edit. Raíces S.A de C.V., Enero-Febrero 2002, México, pp. 36-41. México, pp. 36-37.
} 
Simbólicamente esto se entiende explicando que el Poniente es la región donde se juntan el negro y el rojo, y que Venus, el planeta que es el dios para los aztecas, surge por el Este, antes del sol, transformado en Estrella de la mañana. Pero Hernán Cortés, barbado, de ojos claros y tez blanca, llega a Yucatán desde el Oriente en 1519, año que se llamaba precisamente Ce Ácatl (1 Caña). Por eso las distintas tribus con que se encontró no dudaron ni un momento que el conquistador español era Quetzalcoatl de regreso.

Fig. 10. Representación de Ehécatl-Quetzalcoatl con ehecacózcatl,

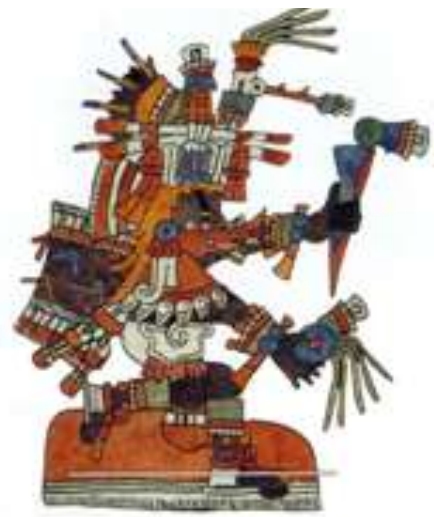

Fuente: Códice Telleriano-Remensis, f.8v.

En Arqueología Mexicana, Vol. IX, Núm. 53, pág. 32

Laurette Sejóurné resume la cuestión de esta dualidad, aparentemente contradictoria y sus implicaciones:

La precisión con la que los textos nos hablan de Quetzalcoatl como rey de Tula confiere una innegable apariencia de realidad a la vida de este reino lejano. La 
ciudad y sus ocupantes están minuciosamente descritos, se detallan las innumerables reformas e innovaciones introducidas por su soberano. Aferrándose a estos datos con tanto más fuerza por constituir el único terreno sólido que ofrecen las crónicas para el período creador, se termina por no preocuparse más de consolidarlos. En esta nostalgia de certidumbre, Quetzalcoatl adquiere dos personalidades distintas, sin relación dinámica entre ellas. De un lado, es una potencia de este mundo en lucha con las pasiones y finalmente derrotado por un rival; del otro, un dios creador, héroe de acontecimientos que escapan a la lógica del sentido común. Después de desembarazarse del segundo, confinándolo a la irrealidad de la mitología religiosa, hay la tendencia de dedicarse al rey, el único juzgado digno de los esfuerzos de los investigadores. De ahí que alcanzar a fijarlo en el espacio y en el tiempo aparezca primeramente como la finalidad misma de los estudios prehispánicos. Sin embargo, se termina por descubrir que este camino tentador por su facilidad no puede conducir a ninguna comprensión de Quetzalcoatl, porque se llega a la conclusión de que su descenso a los infiernos y su 


\begin{abstract}
transfiguración deben, por lo menos, ser tan reveladores de su naturaleza como su actividad social. Es decir, que pronto resulta imposible considerar las dos personalidades separadamente sin privar al mismo tiempo a esta entidad primordial de toda su significación: el comportamiento mítico de Quetzalcoatl está tan indisolublemente ligado a la existencia humana del rey de Tula, como esta última a la divinidad creadora ${ }^{12}$.
\end{abstract}

La figura de Quetzalcoatl sería así arquetípica: representa el personaje del hombre convertido en dios. En la primera parte del mito es el mortal penetrado por la conciencia de su origen celeste y la angustia de su dualidad; en la segunda es el penitente que va hasta los infiernos para apoderarse del secreto de su naturaleza; y en la tercera, liberado de las pasiones y dueño al fin de su unidad interior, es transfigurado en el planeta Venus.

Lo que hace de Quetzalcoatl un simbolo divino para la humanidad es su determinación de cambiar el curso de su existencia, de iniciar una marcha a la cual no lo obliga más que una necesidad íntima, y tras la cual obtiene la superación espiritual y corta con las cadenas que lo atan a la materialidad y a la inercia horizontal.

${ }^{12}$ Séjourné, Laurette, El universo de Quetzalcoatl, pp. 14-15. 


\subsection{Los conceptos fundamentales del arte prehispánico en Mesoamérica.}

En los apartados precedentes se ha visto la importancia fundamental de comprender el horizonte de la cosmovisión mítica y religiosa de los pueblos mesoamericanos para entender no sólo su cultura -en todos los aspectos posibles que abarca este vocablo-, sino también, y en lo concerniente al presente trabajo, el afán perseguido y el lugar que ocupaban sus expresiones artísticas.

Indagar acerca del complejo esquema comunicativo que crea el arte, y dentro del cual despliega sus manifestaciones y se refiere $\mathrm{y}$ retroalimenta, obliga a preguntarse por sus supuestos básicos y generales, y a establecer las características individuales que ha presentado en la civilización mesoamericana.

El ser humano percibe la realidad empírica de su entorno a través de los sentidos. Todo dato de la realidad se convierte en una representación. $Y$ esas representaciones son interpretadas y comprendidas en el marco del horizonte conceptual que posee cada individuo. Este marco conceptual en Mesoamérica, se resuelve siempre en una interpretación mítica que no se limita a registrar solo el aspecto físico de lo percibido, sino que lo entiende siempre en relación con las representaciones cósmicas que posee.

Westheim señala que del mismo modo en que el mito transforma el sentido del fenómeno, transforma también el modo de ver: 
La selección que el hombre realiza al recibir las impresiones ópticas muestra lo que para él es la realidad. El hombre del México prehispánico, arraigado en el mito, impregnado de éste, recurre al mito para interpretar lo que ve. Ve a través del mito. Al pensamiento mítico le corresponde un ver mítico: un ver que descubre en todo fenómeno un sentido mítico. Para aquel hombre el colibrí no es un simple pájaro, es decir, un animal vertebrado, cubierto de plumas, ovíparo, de sangre caliente. Es, primero y ante todo, lo que el mito hace de él: un símbolo de la resurrección. Y cuando lo representa, su "representación" sólo es exacta -exacta para él- si expresa este significado, sin que importe hasta qué punto concuerde con el modelo natural. La transmutación, que no se debe a razones estilisticas impuestas por una $u$ otra tendencia artística, se realiza en la conciencia y en el subconsciente, puesto que entrambos determinan el ver ${ }^{13}$.

${ }^{13}$ Westheim, P., op. cit., pp. 25-26. 
Fig. 11. Sello prehispánico de un colibrí

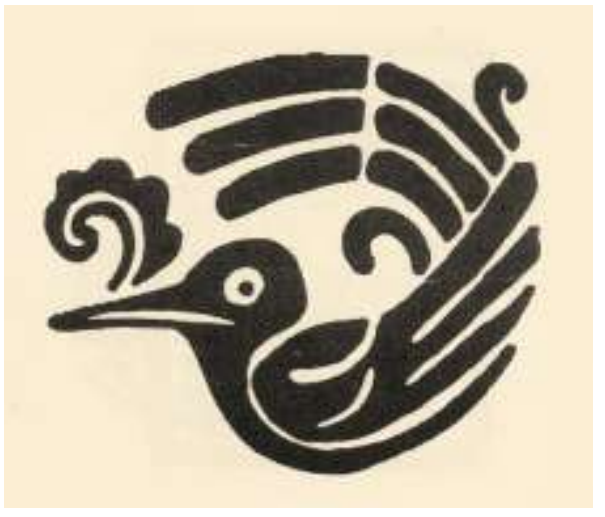

www. Arqueomex.com

Esta metamorfosis del fenómeno natural que se opera en la imaginación del hombre es determinante para la creación plástica, ya que la mayor o menor fidelidad de la representación con su modelo fenoménico, regulada en casos, como se termina de apuntar, por una cosmovisión mítica totalizante, tendrá un impacto directo sobre la resolución formal, el lenguaje visual, que se adopte en la ejecución de la obra de arte. En el caso de la América precolombina, la originalidad de sus expresiones se sustenta sobre el animismo que preside la mayoría de las creencias religiosas, y sobre el rol preponderante que la religión en sí tenía en la vida de estas sociedades, no sólo en su aspecto ritual sino también en lo cotidiano, lo laboral, etcétera.

A un entendimiento mítico de la realidad corresponderá un arte que no se detendrá en la mera reproducción. La estilización que se observa en las obras mesoamericanas responde a un modo de ver específico: como cualquier estética, 
suprime lo que considera superficial, y resalta como fundamento lo que interesa a su idiosincrasia y a sus objetivos de comunicación. Y como cualquier estética, debe crear un idioma particular, un nuevo lenguaje estilístico y simbólico. En el caso de Mesoamérica, el sustento conceptual y significativo de este lenguaje es el mito. De allí, y por lo ya

Fig. 12. Representación estilizada de un JAGUAR. Pintura mural. Clásico Temprano. Pórtico10. Conjunto de los Jaguares. Teotihuacan, Edo. de México.

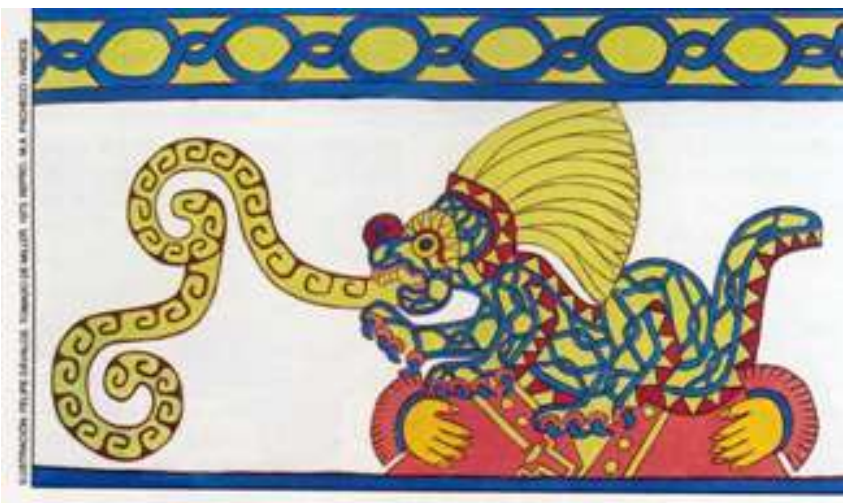

Fuente: Ilustración Felipe Dávalos.Arqueología Mexicana Vol. XII, Núm. 72, pág.32

expuesto en el primer punto del presente apartado, que en la representación del mundo prehispánico no haya diferencia de categoría entre los fenómenos de la naturaleza: todos son entendidos como partes interdependientes de la misma cosmovisión, esto es, de la misma realidad.

El pensamiento mítico actúa con mecanismos similares a los de la metáfora: no asigna a un objeto una significación unívoca, sino que en las asociaciones de sus atributos con el conjunto abre un espectro polisémico: el fenómeno no es 
singular y unitario, sino plural y total. Westheim acerca también pensamiento mítico y metáfora cuando resume: " $\mathrm{El}$ realismo moderno persigue la finalidad de reproducir lo visible, la del realismo mesoamericano es hacer visible lo invisible."

Fig. 13. Representación sígnica de "movimiento" (Ollin, lengua náhuatl.) Friso de la Pirámide de los Nichos, Tajín.

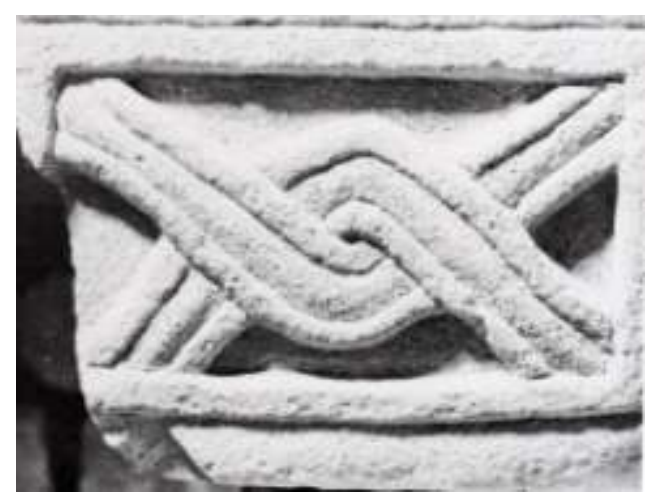

Fuente: Iconografía Arqueológica del Tajín, pag. 198

Estos procedimientos de naturaleza lingüística y semiótica generan, en todo caso, expresiones simbólicas. Sin embargo, la producción de metáforas y de símbolos no sigue caminos similares. En las culturas de pensamiento mítico, a diferencia de la occidental moderna y contemporánea, y los símbolos plásticos, a diferencia de las metáforas, no son invenciones individuales de un solo artista, sino que pertenecen al bagaje de representaciones de la colectividad. Esto explica que en el arte mesoamericano se encuentren variaciones según cada cultura, pero que el acervo, tanto temático como expresivo, muestre una clara regularidad.

La brecha de las representaciones artísticas mesoamericanas respecto de un grado cero de realismo, como lo entendemos 
hoy en día (la referencia univoca, la representación mimética de la $\cos a$ ) responde a esa suma de factores:

\begin{abstract}
El pensamiento mítico se expresa en forma de signos; sustituye la cosa por el signo. Entre signo y cosa puede haber una semejanza óptico-sensible, pero esto no es decisivo. Decisiva es exclusivamente la "relación" entre ambos: relación de índole mágico-mítica -muy remota a veces para el criterio racionalista-, que transforma la realidad real en otra realidad imaginaria y hace que el fenómeno natural adopte, en una existencia trascendental, una nueva significación (...) No se representa la cosa misma, sino la significación que tiene la cosa en la conciencia mágico-mítica ${ }^{14}$.
\end{abstract}

Los signos y simbolos que se encuentran recurrentemente en el arte mesoamericano son los siguientes:

- Árbol: símbolo del universo: representa a los tres reinos del mundo: el inframundo (la raíz), la Tierra (el tronco), el cielo (la copa). Se lo entiende como la cruz cardinal.

${ }^{14}$ Westheim, P., op. cit., pp. 43-44. El subrayado es nuestro. 
Fig. 14. Árbol cósmico maya. Templo de la Cruz Foliada, Palenque, Chiapas, México.

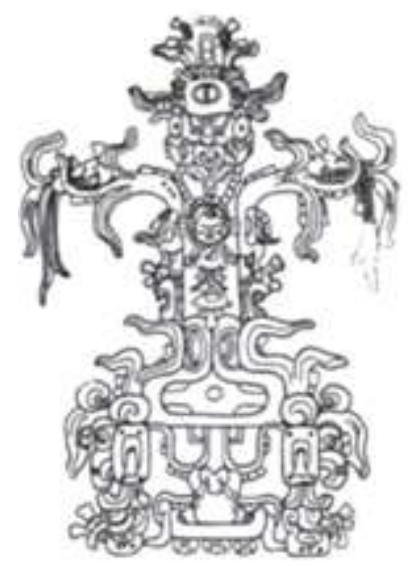

Fuente: Carolyne Tate.

- Animales humanizados generalmente utilizados en la representación de los dioses, en este caso, por ejemplo, la adoración no se dirige al animal mismo, digamos al jaguar, sino al dios Tezcatlipoca, que se representa en forma de jaguar.

Fig. 15. Tepeyóllotl-Tezcatlipoca, dios jaguar Códice Borbónico

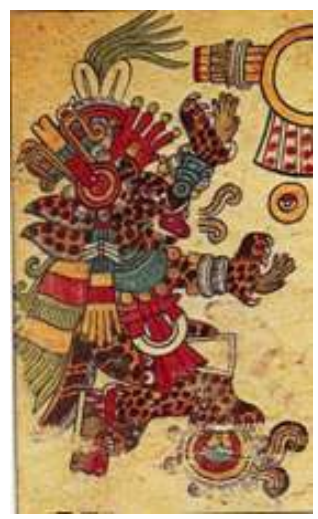

Fuente: Arqueología Mexicana. 
- Plumas: es el símbolo del poder de los dioses. El plumaje es lo que convierte a la serpiente en símbolo de Quetzalcoatl. La pluma se considera como recurso mágico que confiere al ave la capacidad de levantarse sobre todos los seres vivientes. Es símbolo de grandeza sobresaliente, insignia del hombre prócer, a quien eleva por encima de los demás y pone en condiciones de "verlo y oírlo todo".

Fig. 16. Detalle escultórico. Templo de la Serpiente Emplumada en Teotihuacan.

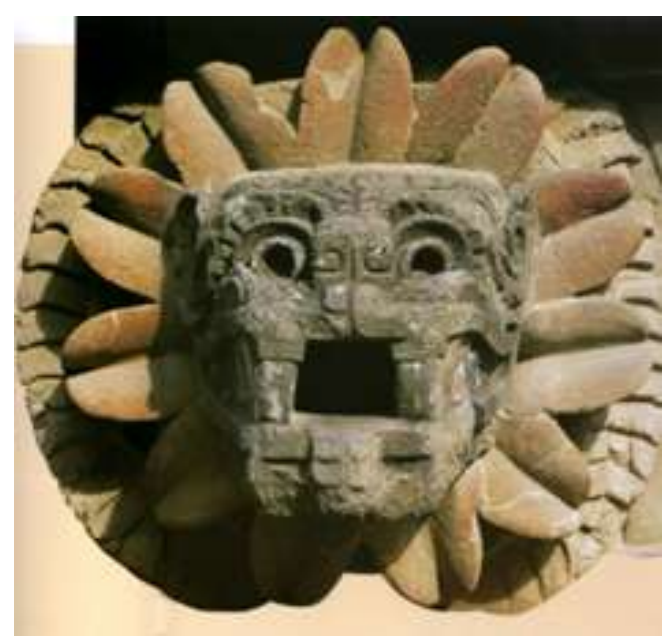

Fuente: Guía Arqueológica México.

- Plantas: ciertas propiedades de las mismas se atribuían a la actuación de los espíritus, y su acción podía ser tan fuerte y tan misteriosa que esas plantas se volvian para el hombre seres sobrenaturales y sagrados (caso del peyote, el tabaco, etc.). Otras, como el maíz, el maguey, 
el cacao se consideraban plantas sagradas en las cuales moraba un espíritu o deidad que les confería virtudes y dones.

Fig. 17. Urna funeraria con la Diosa del Maíz. Cultura zapoteca.

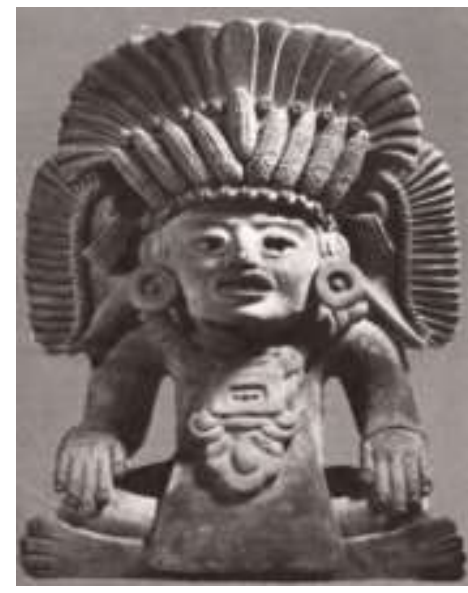

Fuente: Ideas fundamentales del arte prehispánico, pág. 91

Emisor y recetor compartían, a través de estos símbolos, el mismo código, condición esencial para la comunicación. No se trataba de una simple convención sino de un verdadero lenguaje. La obra, para el mesoamericano, era un signo que señalaba y remitía a la totalidad cosmogónica:

La obra de arte no es contemplada con un criterio estético, como expresión de una capacidad de creación artística, realizada dentro de un mundo imaginario de apariencias; se la considera algo real, no más ni menos ni de otra manera real que 
cualquier fenómeno de la realidad, y dotado como ellos de virtudes mágicas (...) En el mundo del pensamiento mágico-mítico la obra de arte no es objeto de la vivencia estética, destinado a "depurar las pasiones": es un vehículo de energías propias para enardecer la pasión religiosa ${ }^{15}$.

\footnotetext{
${ }^{15}$ Westheim, P., op. cit., p. 51.
} 


\section{TEMA 2. LAS CULTURAS DEL CENTRO-NORTE DE VERACRUZ}

Se ha realizado un esbozo general de Mesoamérica, por lo cual se ahondará en la región geográfica del Golfo de México, hacia el centro-norte, donde nace y se desarrolla la antigua civilización de El Tajín, objeto de estudio de este trabajo.

Hoy en día no se tiene un conceso unitario acerca de la cultura original de El Tajin. Diversos investigadores han debatido sobre esta cuestión; existe la opinión de algunos acerca de que El Tajín pertenece al grupo cultural de los totonacas, por la razón que estos han permanecido durante varios siglos en esta zona, incluso sus tradiciones, ritos y danzas han sobrevivido adquiriendo cada vez más importancia. Un ejemplo palpable es el reconocimiento que hiciera recientemente la UNESCO al incluir en la lista del Patrimonio Cultural Inmaterial de la Humanidad, año 2009, a la Danza ritual de los Voladores de Papantla, Veracruz. Esta danza se practicada en El Tajín y otros sitios.

Acerca de la palabra Tajín, se desconoce si así se nombraba originalmente a la ciudad; este vocablo es de lengua totonaca y en su traducción al castellano significa "Rayo o Trueno Viejo", -La Ciudad del Rayo-; el arqueólogo García Payón la nombró "La Ciudad Sagrada de Hurakán", antigua deidad de las tormentas y huracanes. Tajín es comparable también a la 
deidad teotihuacana de la lluvia y la fertilidad conocida como Tláloc.

Fig. 18. Mapa geográfico actual de los sitios arqueológicos de Veracruz.

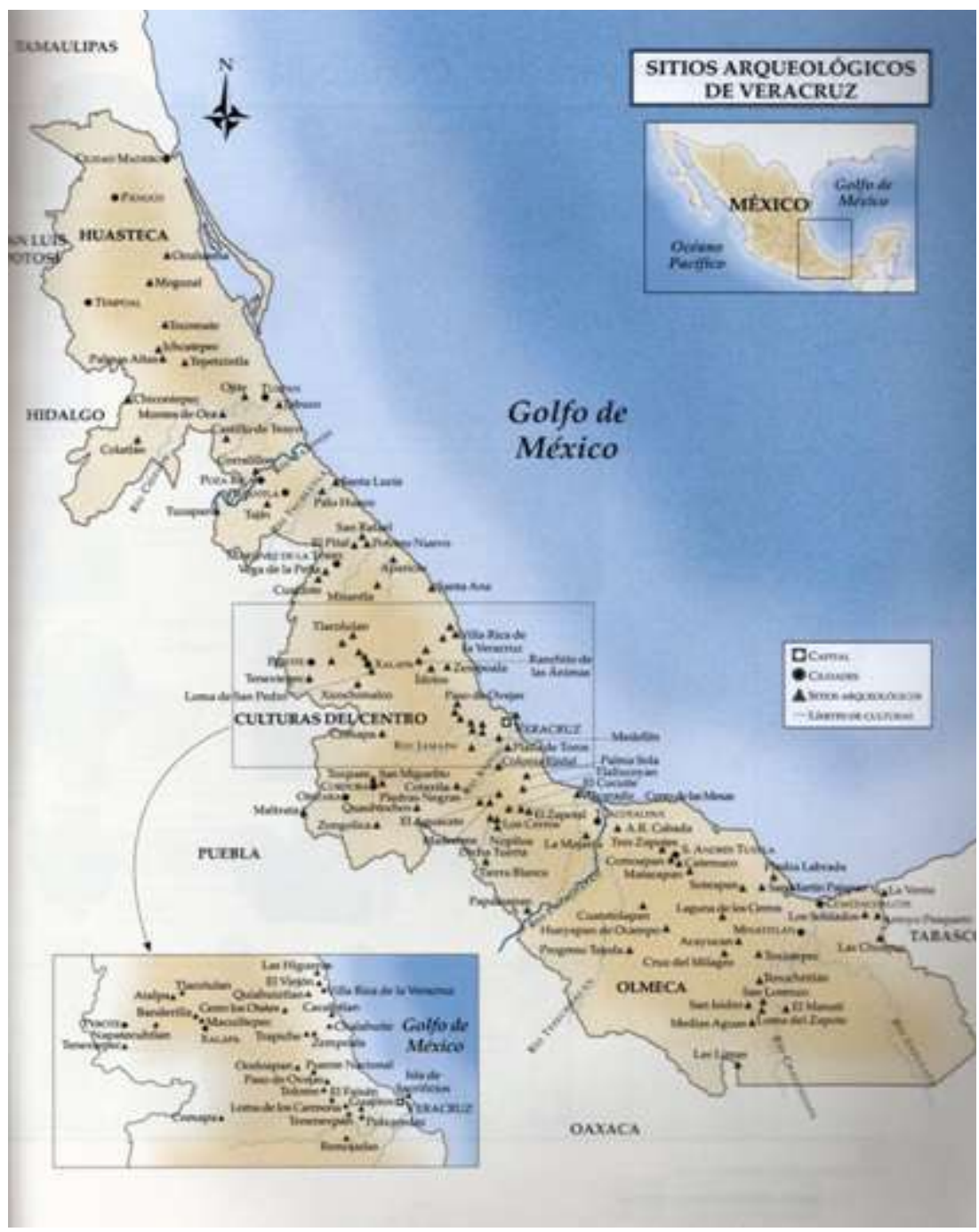

Fuente: Arqueología Mexicana 
A la región que ocuparon los totonacas precolombinos, en torno a la ciudad de El Tajín, se le conoce como el Totonacapan que significa "lugar de totonacas" o "lugar de bastimentos". Según las fuentes históricas, el Totonacapan se extendía del Río Cazones al Río de La Antigua, y también comprendía las faldas de la Sierra Madre, desde Huauchinango hasta Perote. Actualmente, en torno a la ciudad de Papantla, limita al norte con el río Tuxpan, al sur con el río Papaloapan, al oriente con el Golfo de México y al poniente con la sierra poblana.

¿Cuándo o cómo fue la ocupación de los totonacas en esta región? Una de las pocas referencias de los cronistas del s. XVI que hace alusión al origen de los totonacas, es la de Fray Juan de Torquemada16:

...que salieron de aquel lugar que llamaron Chicomoztoc o Siete Cuevas, juntamente con los xalpanecas y que fueron veinte parcialidades o familias, tantos de unos como de otros...eran todos de una lengua y de unas mismas costumbres. Llegados a estas llanadas de la Laguna pararon en el pueblo donde ahora es Teotihuacan, y afirman haber hecho ellos aquellos dos templos que se dedicaron al Sol y a la Luna, que son de grandísima altura.

${ }^{16}$ Citado por Piña Chan, Román/ Castillo Peña, Patricia, Tajín, la ciudad del Dios Huracán. México, Fondo de Cultura Económica, 1999, p. 91. 
Estuvieron alli por algún tiempo y después, o no contentos con el lugar, o con ganas de pasarse a otros, se fueron a Atenamitic, que es donde ahora es el pueblo de Cacatlan; de aquí se pasaron viendo al oriente y dando en las llanadas de Cempoala, junto al puerto de la Vera Cruz, poblándose toda aquella tierra de muchísimo gentío. Estos totonacas, situados en Mizquihuacan, fueron gobernados por una sola cabeza, y gastaron en nueve edades y vidas de otros tanto señores, tiempo de ochocientos años...

De acuerdo a la opinión de Ramírez Herrera, estos totonacas a que hace mención Fray Juan de Torquemada, no corresponden a los primeros grupos aldeanos del Preclásico en Veracruz ${ }^{17}$ :

Por otra parte, no ha existido en la historia prehispánica de la costa del Golfo, y más concretamente en el centro de Veracruz, una continuidad territorial atribuible a la Cultura Totonaca. Si bien los sitios arqueológicos de este espacio geográfico, son atribuídos a los totonacos, esto se debe, fundamentalmente, a que su historia

17 Citado por García Márquez, Agustín, Los aztecas en el Centro de Veracruz", México, Universidad Nacional Autónoma de México : Instituto de Investigaciones Antropológicas : Programa de Posgrado en Estudios Mesoamericanos, 2005, pág. 71 
y etnografia están contenidas en relaciones y documentos del s.XVI, que posiblemente sean aplicables al desarrollo de esta cultura durante el Clásico Tardío (600 - 900 d.C.) y Posclásico (900 - 1521 d.C.). Por lo tanto, estas informaciones, referidas muchas de ellas en relación a lugares costeros como Cempoala y Quiahuiztlan, por ejemplo, mismos que por su situación geográfica sufren la influencia cultural y política del Altiplano, no son procedentes para los grupos agrícolas, con asentamientos rurales, aldeanos, económicamente autosuficientes del Preclásico del centro de Veracruz.

Otras fuentes documentales afirman que la llegada de los totonacas a las costas veracruzanas fue entre 800 y 1100 d.C. (período Posclásico), es decir, esta fecha es muy posterior a la considerada por algunos autores como Piña Chan y Medellín Zenil.

Si se tiene en cuenta, por otro lado, el aspecto lingüístico, durante el Preclásico estuvieron presentes otras etnias como los protomayas que recibieron la influencia de los olmecas arqueológicos y que hablaban lengua protomixe-zoque. Posteriormente se dividieron hacia el norte (donde se conocerán como huastecos) y hacia el sur (donde se unirán al maya de Yucatán); estos grupos conservaron su origen 
lingüístico de la familia maya, hablando huasteco o el cotoque. Y, en la parte central alrededor del año 1500 a.C. comienza a formarse la llamada cultura de Remojadas, de la cual se hará mención más adelante.

Por todo lo anterior, no se puede llegar todavía a una conclusión definitiva; lo que sí es posible afirmar, es que El Tajin es heredera cultural de los pueblos que habitaron esta región costeña desde el Preclásico. Asimismo, los estudiosos han decidido nombrar "La cultura de El Tajín" a los artífices y constructores de esta antigua civilización prehispánica. De igual forma se referirá a ella en el desarrollo de esta investigación.

La cultura de Remojadas aporta un antecedente de gran relevancia artística dentro del área geográfico-histórica; sus magníficas cerámicas, esculturas de talla natural, ofrendas mortuorias, todas ellas modeladas con un estilo regional, original y altamente simbólico dan cuenta del desarrollo que alcanzaron.

Es de interés mencionarla como antecedente significativo, con ciertos rasgos en la forma, composición y estilo de elementos que también podemos observar posteriormente en El Tajín.

\subsection{Remojadas y su legado artístico.}

El nombre de Remojadas le fue dado por el principal estudioso de esta cultura, el arqueólogo Alfonso Medellin Zenil, quien 
lleva a cabo las primeras excavaciones entre los años de 19491950. Sus trabajos arqueológicos en distintas zonas del centro de Veracruz, son de gran importancia, ya que pudo establecer una secuencia cronológica de esta cultura primigenia, fechada entre el año 400 a.C. - 800 d.C.; también ubica la cronología para los totonacas. A continuación se muestra un cuadro realizado tomando en cuenta las investigaciones de Medellín Zenil18:

\begin{tabular}{|c|c|c|c|}
\hline POBLACION & TEMPORALIDAD & CULTURA & $\begin{array}{l}\text { SITIOS } \\
\text { ARQUEOLÓGICOS }\end{array}$ \\
\hline $\begin{array}{l}\text { Totonaca } \\
\text { Pre-clásico }\end{array}$ & $\begin{array}{l}\text { Preclásico } \\
1500-0 \text { a.C. }\end{array}$ & $\begin{array}{l}\text { Remojadas } \\
\text { Inferior }\end{array}$ & $\begin{array}{l}\text { San Rafael, San } \\
\text { Miguelito, } \\
\text { Tenextepec, } \\
\text { Quauhtochco, } \\
\text { Tolome, El Faisán, } \\
\text { Alvarado, } \\
\text { Remojadas, Viejón. }\end{array}$ \\
\hline $\begin{array}{l}\text { Totonacas } \\
\text { Clásico- } \\
\text { Temprano }\end{array}$ & $\begin{array}{l}\text { Clásico } \\
\text { Temprano } \\
\text { 0-300 d.C. }\end{array}$ & $\begin{array}{l}\text { Remojadas } \\
\text { Superior I }\end{array}$ & $\begin{array}{l}\text { Polvaredas, } \\
\text { Tenexpan, } \\
\text { Cerros, Nopiloa, } \\
\text { Lomas de los } \\
\text { Carmona, Tolome, } \\
\text { Remojadas. }\end{array}$ \\
\hline Totonacas & $\begin{array}{l}\text { Clásico Tardío } \\
400-800 \text { d.C }\end{array}$ & $\begin{array}{l}\text { Remojadas } \\
\text { Superior II }\end{array}$ & $\begin{array}{l}\text { Polvaredas, } \\
\text { Nopiloa, } \\
\text { Napatecutlan, } \\
\text { Cacalotlan, } \\
\text { Los Cerros, Dicha } \\
\text { Tuerta, Potrero } \\
\text { Nuevo. }\end{array}$ \\
\hline Totonacas & $\begin{array}{l}\text { Posclásico } \\
\text { Temprano }\end{array}$ & $\begin{array}{l}\text { Isla de los } \\
\text { Sacrificios }\end{array}$ & Isla de Sacrificios \\
\hline
\end{tabular}

18 swadesh.unam.mx/actualidades/.../medellin.html 


\begin{tabular}{|l|l|l|l|}
\hline & $900-1100$ d.C. & & \\
\hline Totonacas & $\begin{array}{l}\text { Posclásico } \\
\text { Tardío } \\
1200-1500 \text { d.C. }\end{array}$ & $\begin{array}{l}\text { Cempoala- } \\
\text { Quiahuiztlan }\end{array}$ & $\begin{array}{l}\text { Cempoala, Villa } \\
\text { Rica, Quiahuiztlan, } \\
\text { Los Otates, } \\
\text { Quauhtochco, } \\
\text { Comapan, } \\
\text { Tuzapan. }\end{array}$ \\
\hline & & & \\
\hline
\end{tabular}

Como se puede observar en el cuadro anterior, la temporalidad de Remojadas abarcó varios períodos históricos y sitios geográficos diversos; sin embargo, durante todo este tiempo, siguió conservando sus formas, expresiones plásticas y simbólicas que le son comunes y por lo cual se identifica a esta cultura de artesanos alfareros. Medellín Zenil expresa sobre su arte lo siguiente ${ }^{19}$ :

La impresión general que produce al observador la contemplación de los restos de esta cultura es la de un pueblo satisfecho, plácido y amante de exaltar la naturaleza, la fecundidad y la belleza femenina. Se pueden descubrir en dicha contemplación los inicios del culto al Sol, la Luna, Venus, el viento (EhecatlQuetzalcoatl), y la agricultura (XipeTotec)...En lo que a la plástica se refiere hay gran libertad en la concepción y ejecución así como gran sencillez y amplitud de líneas en la escultura; empleo de la técnica de

${ }^{19}$ Citado por García Márquez, Agustín, Los aztecas en el Centro de Veracruz", México, Universidad Nacional Autónoma de México : Instituto de Investigaciones Antropológicas : Programa de Posgrado en Estudios Mesoamericanos, 2005, pág. 69 
modelado en barro, decoración y expresión de rasgos por pastillaje e incisiones; desnudo y tatuajes, miembros rudimentarios y rigidez de los mismos en la escultura antropomorfa; cerámicas monocromas, ausencia casi absoluta de soportes en las vasijas, decoración negativa, esgrafiado; uso del cinabrio, tizatl, chapopote y jade.

Estas características estuvieron presentes durante su desarrollo, habiendo evolucionado y adquiriendo su más alta expresión, tanto técnica como plástica, en el período Clásico. Es importante mencionar que Remojadas recibió la influencia de elementos artísticos de Teotihuacán, ya que hubo una constante relación entre la Costa del Golfo, que servía como vía de paso comercial entre el Altiplano y la zona costera de Veracruz, así como también hubo contactos con la región maya y la zona sur de Veracruz formando una red de comunicación e intercambio tanto de objetos como de ideas culturales.

A continuación se expondrán las características más sobresalientes de Remojadas en cada período de su desarrollo histórico:

En la escultura: Periodo: Remojadas Inferior. Técnica: modelado de delicadas figurillas humanas de arcilla, aplicando pastillaje para los rasgos físicos de boca, ojos y tocados. 
Lo más importante es el empleo de un betún o brea negra que llamaron "chapopote" 20 el cual lo utilizaban como pintura con la que cubrian algunas partes de las figuras ya sean los ojos, detalles de la vestimenta, boca, etc. o les daban un maquillaje corporal y facial, marcando diseños geométricos y simbólicos que las hacian inconfundibles.

Iconografia: representaron figuras humanas de hombres $y$ mujeres, niños, con su indumentaria regional, como tocados de variadas formas con aplicaciones simbólicas de diseños geométricos, orejeras, máxtlatl, cetros, barras y bultos ceremoniales. Las mujeres vestían el enredo, tocados, collares, orejeras circulares. Rostros triangulares, en posición sedente, y de pie. También representaron animales caninos como el

Fig. 19. Bracero para quema de copal. Fase Remojadas Superior (200 a.C.800 d.C.)

Centro de Veracruz

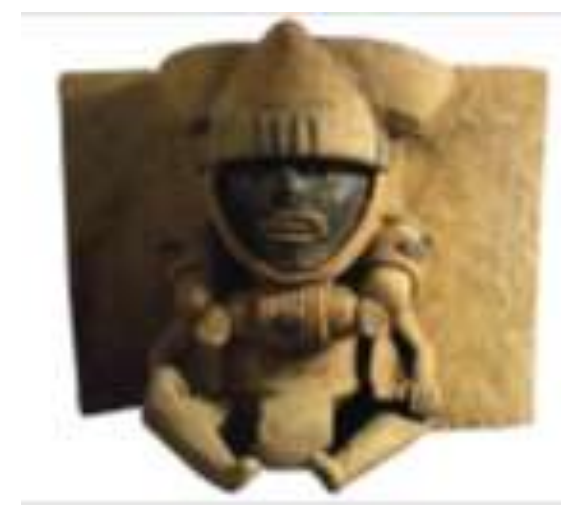

Fuente: www.fundacionarmella.org
Fig. 20. Cabeza antropomorfa con tocado en forma de guajolote. Fase Remojadas Inferior (1000 a.C. -100 a.C.)

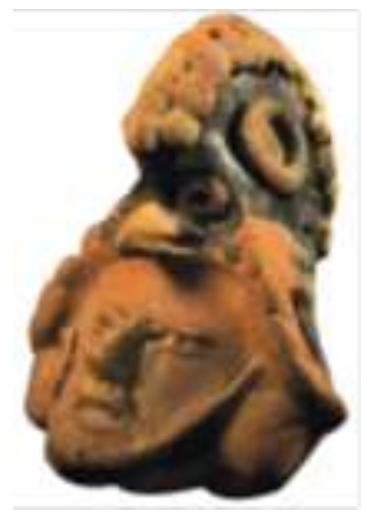

Fuente: www.fundacionarmella.org

${ }^{20}$ El chapopote, vocablo de origen nahuatl, es un betún o brea color negro y pegajoso que se obtenía de afloramientos naturales que brotaban de la tierra en toda la región del estado de Veracruz. 
perro y otros seres fantásticos como "el monstruo de la tierra". (en yugos labrados con volutas 100 a.C-100d.C., alusiones a la decapitación ritual y al juego de pelota.

Fig. 21. Mono con ruedas y pintura de chapopote.

Cultura de Remojadas, Veracruz

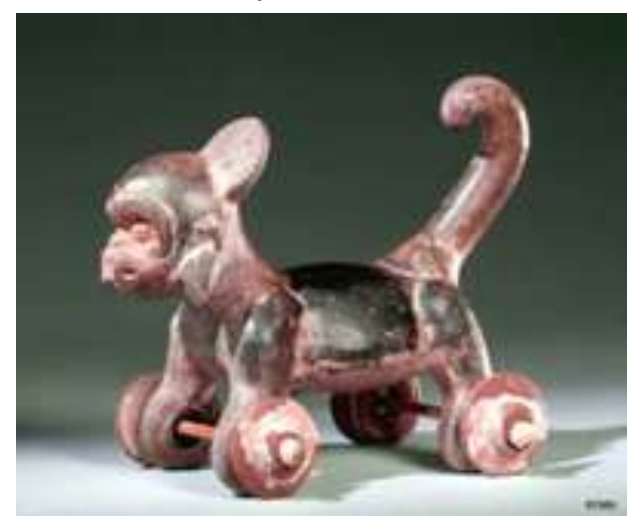

Fuente: www.famsi.org
Fig. 22. Perro en posición sedente y pintado con chapopote.

Cultura de las Remojadas, Veracruz

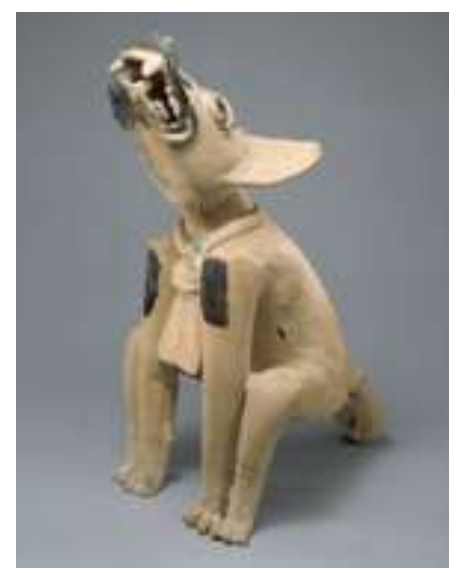

Fuente: www.metmuseum.org

Periodo: Remojadas Superior I y II (desarrollo de formas de Remojadas Inferior)

Técnica: Durante este período, que coincide con el Clásico temprano y Clásico tardío, las figuras alcanzan su máximo expresión. Emplearon moldes y confeccionaron esculturas a tamaño natural huecas.

Iconografia: Figuras de personajes que se utilizaron en ofrendas funerarias y recreaban rituales simbólicos acompañando a los muertos. Figuras antropomorfas de dioses, 
figuras femeninas de diosas, las enigmáticas "caritas sonrientes", denominadas así por la expresión de sus rostros, con tocados que muestran símbolos geométricos afines con El Tajín. Detalles escultóricos de animales simbólicos como el jaguar, murciélago, lagartos, serpientes, cráneos humanos; en los tocados femeninos monos arañas, garzas, lagartos y en cajetes, apaxtles, vasijas zoomorfas destaca el mono araña.

Deidades representadas:

- Dioses narigudos, llamados así por su nariz prominente, en posición sedente y con diversos $\mathrm{y}$ variados tocados, semejantes en variedad a los que portan las llamadas caritas sonrientes.

- Diosas Cihuateteo, mujeres diosas, que habian muerto en su primer parto.

- Dios descarnado del inframundo: Mictlantecuhtli.

- Sacerdotes que llevan cajas de ofrendas.

- Dios de la lluvia, Tláloc.

- Deidad suprema Quetzalcoatl.

- Dios viejo del fuego Huehueteotl.

Signos representados:

- Ollin: en los tocados que portan las figurillas de "carita sonriente", en aplicación de enredos femeninos, 
- Greca Escalonada: representación geométrica del caracol marino, símbolo de Quetzalcoatl, en tocados, enredos femeninos

- Cruz en forma geométrica con un punto en el centro, también podría interpretarse como el quicunce o cruz de Quetzalcoatl

- por representar 5 puntos o regiones sagradas.

Fig. 23. Figuras al pastillaje, dios narigudo derecha

Remojadas Superior
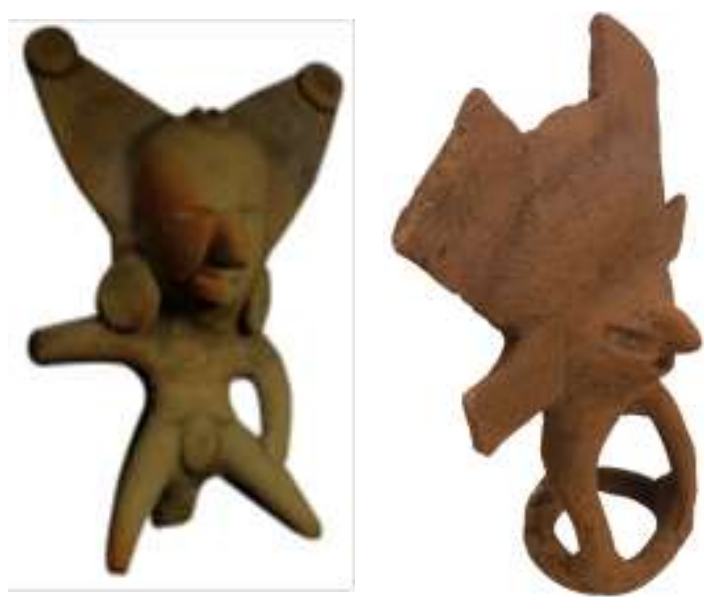

Fuente:www.fundacionarmella.org 
Fig. 24. Figura femenina de 47.3

$\mathrm{cm}$. con rostro sonriente y signo de ollin en el tocado.

Remojadas Superior

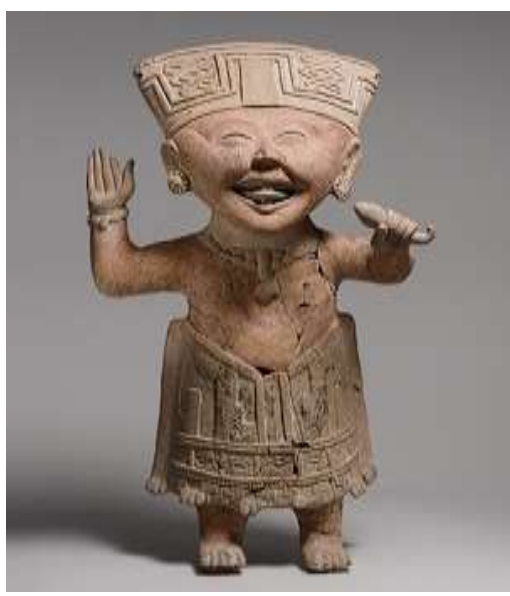

www.metmuseum.org
Fig. 25. Personaje procedente de El Zapotal. Se observa la greca escalonada como detalle en su indumentaria y restos de betún negro característico de Remojadas.

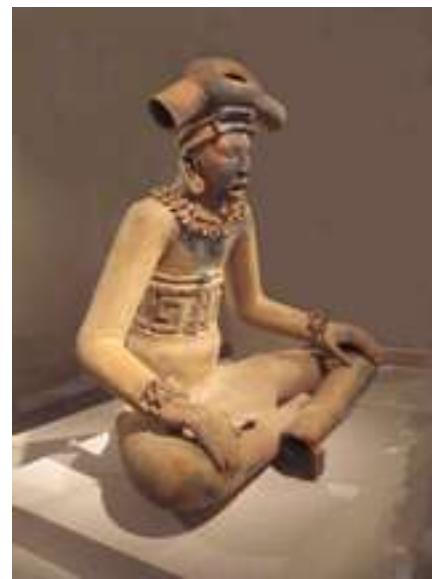

Fuente: www.wikipedia.org

Fig. 26. Representación de Tláloc. 48 X 27 cm. Clásico tardío. El Zapotal.

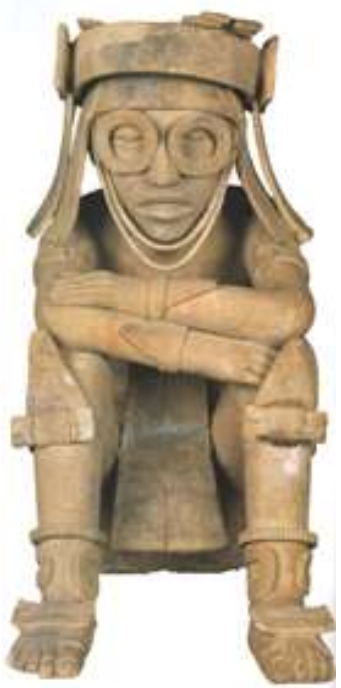

Fuente: Arqueología Mexicana, Edición Especial Núm. 22 


\subsubsection{La ofrenda mortuoria de El Zapotal, Veracruz.}

La zona arqueológica de El Zapotal se encuentra al sureste del estado de Veracruz, en la región conocida como La Mixtequilla. En este sitio hubo un asentamiento prehispánico en el cual se han encontrado hasta 30 pirámides de arcilla que se encuentran aún sin explorar. Bajo una de estas pirámides, los arqueólogos realizaron uno de los hallazgos más importantes relacionados con las culturas antiguas de Veracruz. Se trata de un santuario con una ofrenda masiva en honor a la deidad del inframundo, conocida por los aztecas como Mictlantecuhtli. A decir de los expertos, la ofrenda mortuoria de El Zapotal es la más importante de Mesoamérica.

Al respecto, Nahmad Molinari, quien ha recopilado los escasos estudios y teorias recientes sobre el complejo mortuorio de El Zapotal hace una descripción del hallazgo ${ }^{21}$ :

...el adoratorio se encontró en una galería subterránea, cuyo sitio principal era ocupado por Mictlantecuhtli, sentado en un trono fastuoso y ataviado con el tocado sacerdotal lleno de simbolismos que reflejaban su jerarquía. En la corona destacan relieves de cráneos, cabezas de jaguar, y en la parte central, la figura de un murciélago, símbolo correspondiente a Tezcatipotlatl (Señor de la Noche), que

\footnotetext{
${ }^{21}$ Nota publicada en www.lajornada.unam.mx
} 
muchas veces es confundido con Mictlantecuhtli. Atrás de la figura central zoomorfa, se distingue a Quetzal-coátl, otro de los dioses supremos del panteón precolombino.

Fig. 27. Mictlantecuhtli, el descarnado Señor de la Muerte/Ofrenda mortuoria en El Zapotal, Veracruz/Clásico tardío

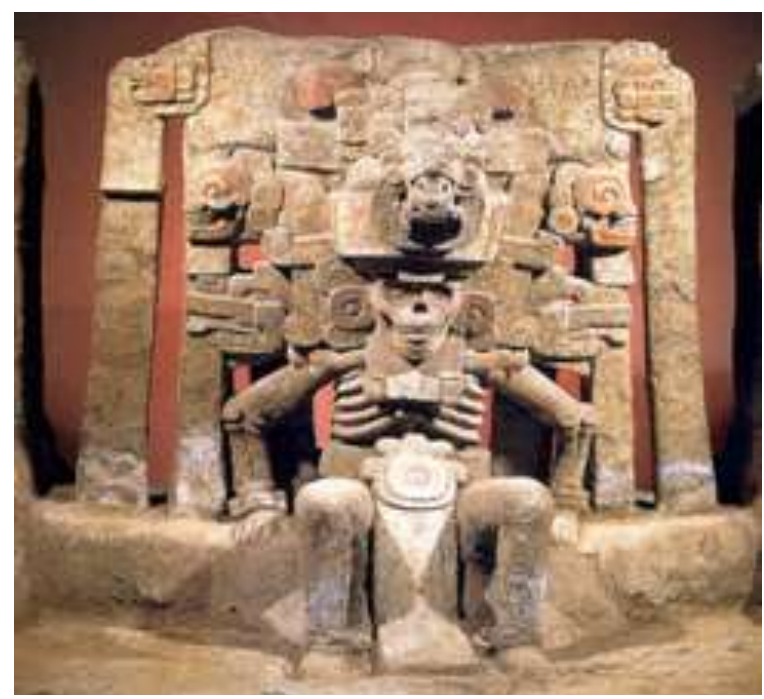

Fuente: www.latinamericanstudies.org/zapotal.html

En la imagen también se puede observar que en su cuerpo está representado el concepto dual de la cosmovisión prehispánica, ya que una parte de él está descarnado -torso, rostro, brazos, y la otra es de un ser viviente -manos, piernas y pies; vida y muerte modeladas en esta escultura cargada de simbolismos. En su rostro sonriente y con la lengua fuera, se contempla una expresión que es un enigma para los 
espectadores y arqueólogos. Otros datos interesantes son que originalmente el trono estaba rodeado por un extenso osario que a manera sacra semejaba una columna vertebral que aglutinó a más de 82 esqueletos humanos, algunos sepultados en posición de loto, meditando ante el señor del Mictlán.

La figuras modeladas en barro de esta magna ofrenda son de distintos tamaños y proporciones; las que representaban a las diosas Cihuateteo o Cihuateot son de tamaño natural alcanzando la medida de $1.50 \mathrm{~m}$; estaban totalmente policromadas y muestran el torso desnudo, los ojos cerrados, ataviadas con grandes y vistosos tocados de diseños geométricos, con enredos (falda a la usanza prehispánica) y sobresalientes cinturones formados por serpientes anudadas al frente, orejeras, collares, ajorcas. Otras figuras de tamaño menor son las llamadas "caritas sonrientes", que han cobrado popularidad por la expresión de sus rostros sonrientes. Son de tamaño menor que las anteriores y también portan indumentaria con elementos iconográficos de contenido simbólico. Estas se encontraron acompañando a osamentas de mujeres. Otras figuras representan a sacerdotes cargando cajas de ofrendas, dioses de la lluvia, braceros efigies, innumerables figurillas en posturas diversas, personajes cautivos, viejitos, hachas, jugadores de pelota, etc.

Esculturas cerámicas con calidad similar a las de El Zapotal también se encuentran en sitios como Apachital, Loma de los Carmona, Cocouite y Nopiloa, todos ellos pertenecientes a Remojadas. 
Fig. 28. Cihuateotl, Clásico Tardío, El Zapotal

Cerámica $120 \times 52 \mathrm{~cm}$.

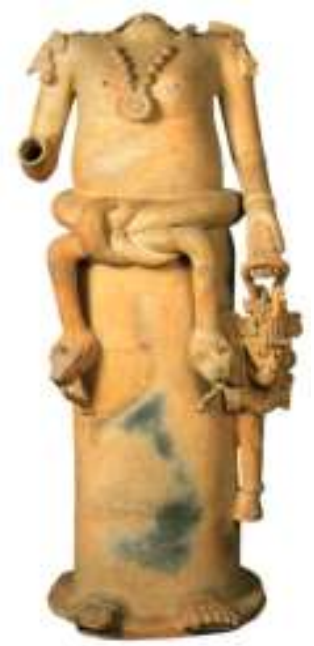

Fuente: Arqueología Mexicana
Fig. 29. Cihuateotl, Clásico

Tardío, El Zapotal

Cerámica 151 X $68 \mathrm{~cm}$.

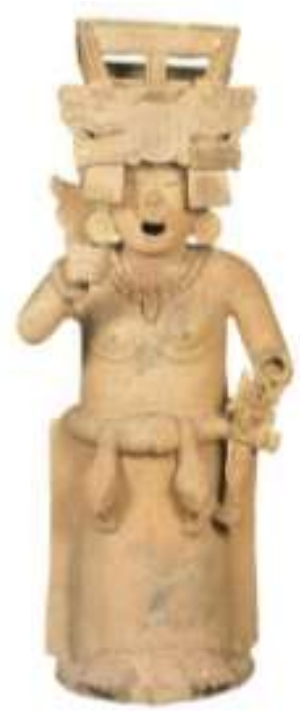

Fuente: www.arqueomex.com

Fig. 30. Caritas sonrientes.Clásico Tardío. El Zapotal
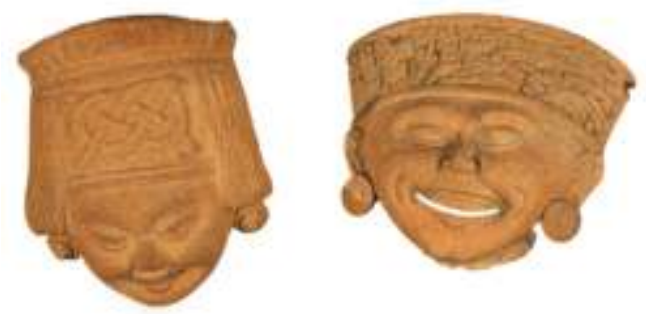

Fuente: Arqueología Mexicana 
Fig. 31. Osamentas acompañadas de figurillas "caritas sonrientes" Ofrenda a Mictlantecuhtli de El Zapotal, Veracruz

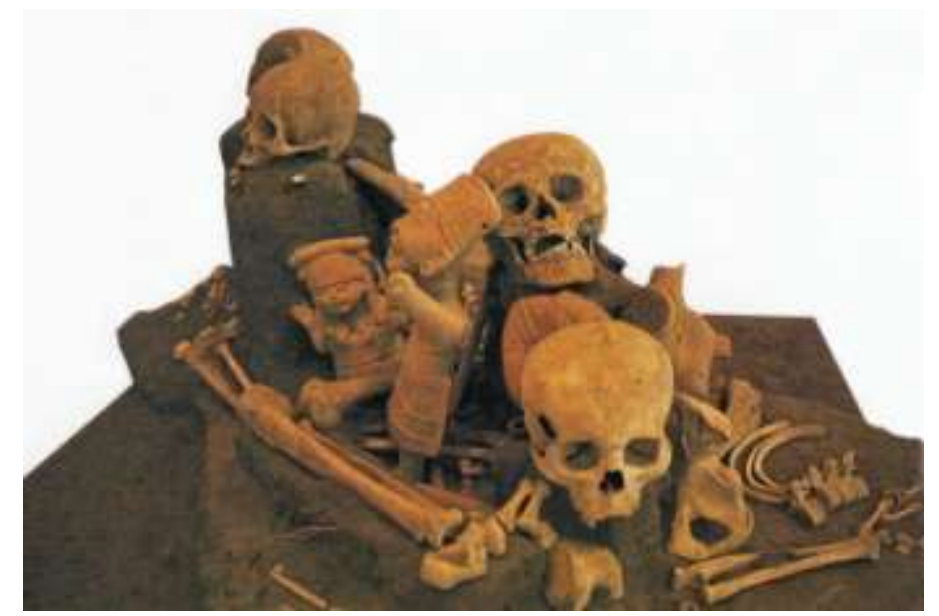

Fuente: Arqueología Mexicana

\subsection{Cerro de Las Mesas}

Cerro de las Mesas es un yacimiento arqueológico situado, al igual que E1 Zapotal, en el área de la Mixtequilla, a $50 \mathrm{~km}$ de la ciudad actual de Veracruz y cerca del río Papaloapan.

Su ocupación se estima entre los 600 a.C. - 900 d.C. considerándose parte de la cultura epi-olmeca y también formando parte de la cultura clásica de Veracruz, como capital urbana de esta región a partir del siglo III d.C.

Existe muy poca información de la historia y desarrollo de este sitio por la falta de investigaciones. De su arquitectura se sabe que casi no utilizaron la piedra en sus edificaciones, 
empleando tierra comprimida y arcilla. Durante la expedición realizada por la Smithsonian y la National Geographic Society, entre los años de 1939-1940, M. W. Stirling, registra 20 monumentos grabados, muchos de los cuales fueron encontrados en la ahora llamada Plaza de los Monumentos, especialmente las estelas $3,5,6,8$ y 9, en las cuales se advierten personajes ricamente ataviados portando elementos simbólicos, por lo que representarian a personajes de alto rango; estas estelas además muestran inscripciones glíficas y numerales, calendáricos como los utilizados por los mayas, adquiriendo mayor importancia por considerarse un tipo de escritura.

Se encontraron también osamentas y alrededor de 800 artefactos hechos de jade, hecho que ha llamado la atención de los investigadores tanto por la cantidad como por los distintos tipos, algunos de ellos con inscripciones de fechas, que fueron depositados como ofrenda funeraria en la base de una de sus edificaciones.

Cerro de las Mesas se caracterizó además, y al igual que otros sitios de Veracruz central, por la creación de figuras cerámicas grandes y huecas representando a sus divinidades, de las cuales destaca el dios viejo del fuego, Huehueteotl.

En la representación plástica de algunas de sus cerámicas y esculturas se puede observar el empleo de volutas, motivo de representación gráfica que fue ampliamente utilizado en los bajorrelieves escultóricos del juego de pelota en El Tajín. 
Fig. 32. Dibujo de tiesto cerámico con diseño de volutas. Cerro de las Mesas

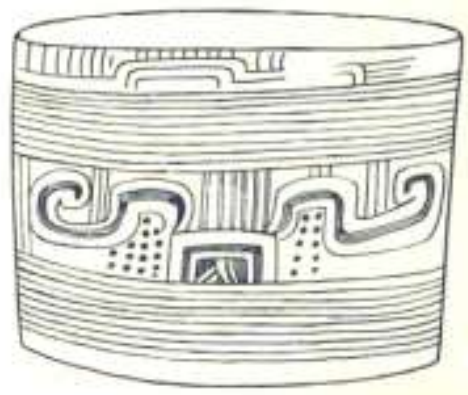

Fuente: catarina.udlap.mx

Fig. 33. Estela 6 Cerro de las Mesas

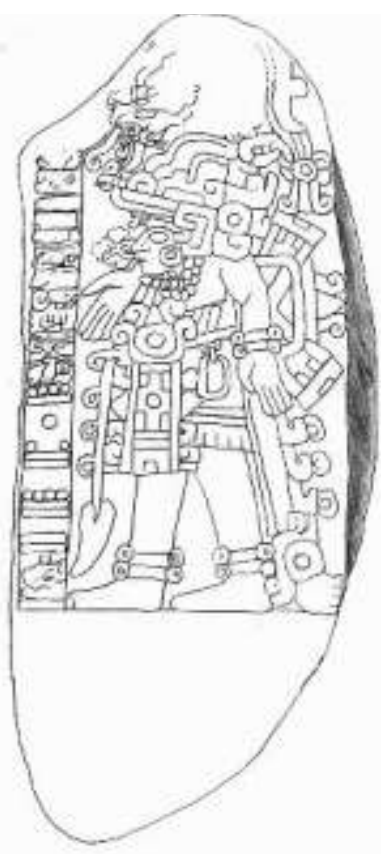

Fuente: www.wikipedia.com
Fig. 34. Estela 8 Cerro de las Mesas

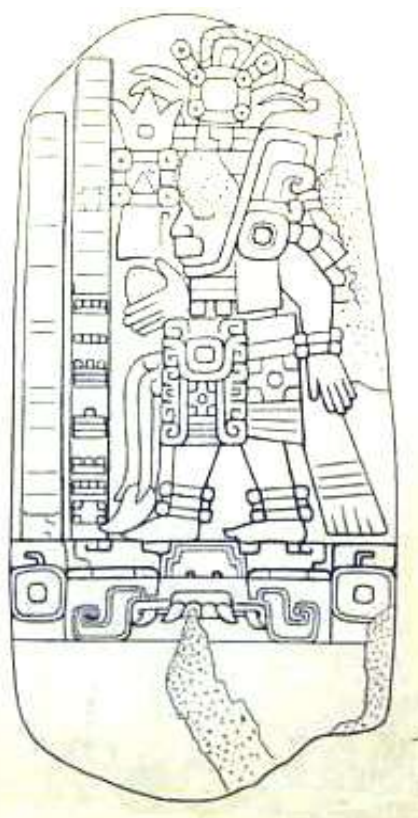

Fuente: catarina.udlap.mx 
Fig. 35. Monolito de piedra de gran formato. Muestra los ojos con volutas ampliamente utilizado en El Tajín para representar a sus deidades.

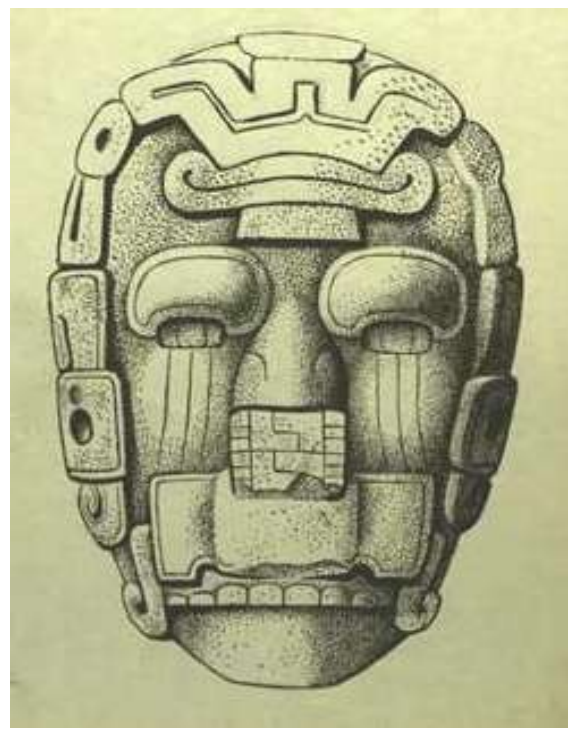

Fuente: Dibujo: Miguel Covarrubias catarina.udlap.mx
Fig. 36. Escultura hueca del Dios Viejo del Fuego Huehueteotl

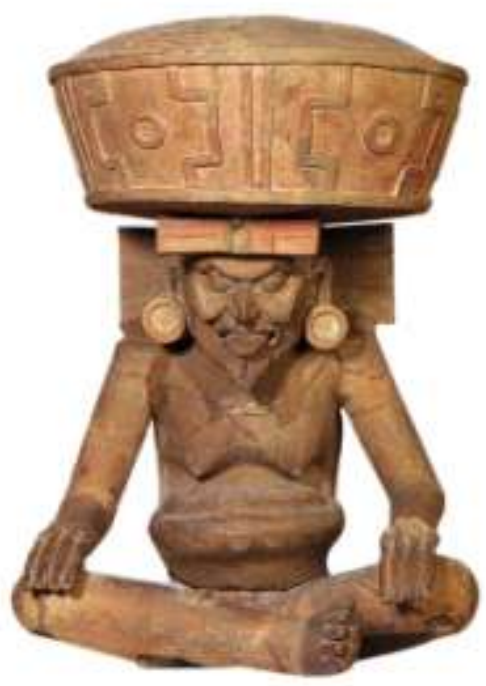

Fuente: www.arqueomex.com

\subsection{Complejo de Yugos-Hachas- Palmas}

En la costa del Golfo de México se desarrolla una especial tendencia por los cultos relacionados con el deporte sagrado del Juego de Pelota; se cree además que el origen de esta práctica tuvo lugar allí. Desde el Preclásico se han encontrado numerosas canchas tanto en sitios grandes o pequeños, así como también material lítico relacionado con el juego de pelota, conocido como "Complejo de yugos, palmas y hachas", todas ellas provenientes en su mayor parte de la zona central de Veracruz. Son esculturas tridimensionales, de piedra compacta (dioritas y nefritas), talladas con bajorrelieves que 
muestran diversos motivos que van desde animales fantásticos, aves, reptiles, plantas, personajes humanos como jugadores de pelota, sacerdotes, deidades, etc.; los escultores adaptaron estos motivos con gran habilidad e ingenio a las formas características de cada elemento creando imágenes de gran plasticidad en la composición y desarrollo técnico.

El estilo de representación artística utilizado en estas esculturas está directamente relacionado con el denominado "estilo clásico veracruzano" o "estilo Tajín”, en el que se hace uso de lineas dobles o sencillas entrelazadas en forma de volutas y ganchos que se unen formando una continuidad visual en la composición; se utilizan sólo líneas curvas de carácter orgánico.

Los yugos, hachas y palmas representan un extraordinario patrimonio visual del uso de un estilo original, creativo $y$ simbólico, que supo amalgamar la influencia olmeca, teotihuacana, maya y de otras culturas con las cuales tuvo contacto esta región de gran movilidad comercial y cultural; este estilo es característico en los edificios del Juego de Pelota en El Tajín.

A continuación se hará una breve descripción de estas piezas:

Los yugos: Durante el desarrollo del juego ritual de la pelota, los jugadores debían proteger su cintura y los órganos internos con anchos cinturones, hechos probablemente de madera y forrados con textiles de algodón y cuero. Estos protectores se 
cree que son el antecedente de las esculturas llamadas "yugos", similares en su forma de uso y numerosas representaciones encontradas en figurillas, cerámicas, frisos, estelas, códices, etc. Se tiene el ejemplo de una estela encontrada en el valle de Maltrata, Veracruz en la que se puede observar a un jugador de pelota portando yugo y demás indumentaria propia del juego; es asistido por otro personaje para ponerse su equipo protector. Se le conoce como la estela de Tepatlaxco.

Fig. 37. Dibujo e llustración de la estela de Tepatlaxco.

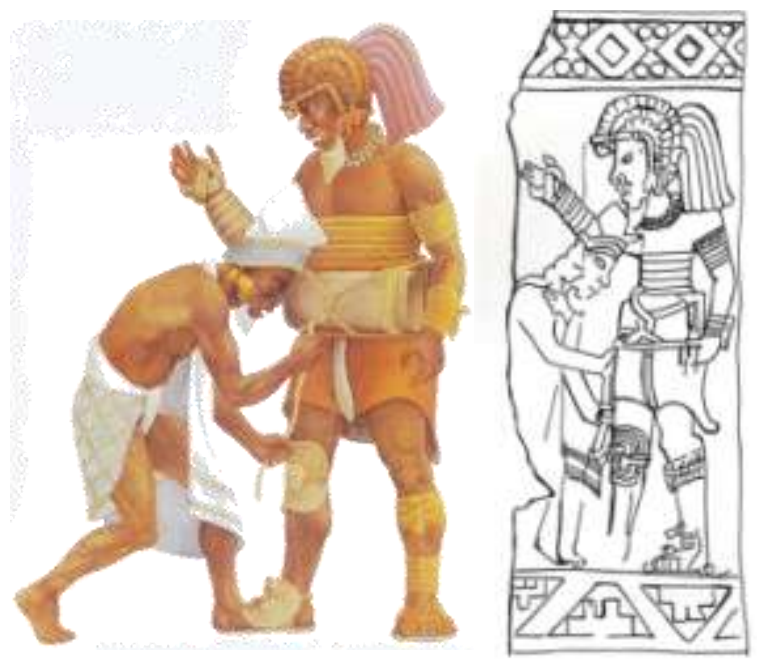

Fuente: www.arqueomex.com

Forma: Los yugos tienen la forma de U o herradura, generalmente, y se pueden ver en sus diferentes variantes como:

- yugos abiertos, que son los más abundantes

- yugos cerrados

- yugos con bajo y alto relieve en su superficie 
- yugos lisos: sin iconografia y sin bajorrelieves.

- yuguitos (por su formato pequeño)

- yugos con elementos añadidos, los hay con hacha integrada, recipiente o vasija.

Formato: Los yugos en forma de $\mathbf{U}$ van aproximadamente desde los $40 \mathrm{~cm}$ de largo por $30 \mathrm{y}$ tantos de ancho y de espesor variable entre 11 y $15 \mathrm{~cm}$, hasta $35 \mathrm{~cm}$. Los yugos cerrados alcanzan los $51 \mathrm{~cm}$. de largo. Los de tamaño menor son los llamados "yuguitos" que miden entre un promedio de $10 \mathrm{~cm}$ hasta $13 \mathrm{~cm}$, no alcanzando medidas mayores. Algunos fueron encontrados en El Opeño, Michoacán que datan del Período Formativo o Preclásico (1500-500 a.C.), por lo cual se consideran como antecedentes del yugo.

Iconografia: Se pueden identificar motivos como:

- rostros humanos de frente y de perfil con orejeras

- cuerpos humanos, brazos, manos, torso

- personajes nadando

- sacerdotes

- seres mitológicos: los Héroes Gemelos del Popol Vuh, Dios del Pulque

- cráneos humanos

- seres antropomorfos: monstruo de la tierra

- animales mitológicos: sapos y ranas, sapos, serpientes, aves, búho, mono, jaguar

- fauna: planta del maguey 
Posibles usos y simbologia:

- ritos funerarios

- ritos mágicos relacionados con el propósito de hacer llover y de ayudar a las personas en el trabajo de desarrollo de sus fuegos sagrados espinales.

- protección

- esculturas ceremoniales que simbolizan el poder y la fuerza

Estilo: En el estilo utilizado en la representación de las imágenes se aprecia la intención del artista de crear una composición compacta en la que todos sus elementos mantengan una continuidad visual, sin espacios vacíos, con formas onduladas, rompiendo la rigidez de la piedra, respetando siempre la forma inicial de origen, la herradura, sobre la cual se adaptan todos sus elementos de diseño. La simetría es aliada de estas esculturas, partiendo de una imagen central al frente que se despliega a cada uno de los lados, con diseños intrincados empleando los entrelaces y volutas del estilo clásico veracruzano o "estilo Tajín". La representación de las imágenes combina el naturalismo de los rostros en contraparte con la estilización de animales como ranas o sapos; se añaden además elementos de carácter simbólico.

A continuación algunos ejemplos de yugos, en su mayor parte provenientes de la costa del Golfo: 
Fig. 38. Yugo Tajín, Costa del Golfo. Piedra. Profusamente decorado a base de volutas y en la parte frontal se aprecia un cráneo humano.

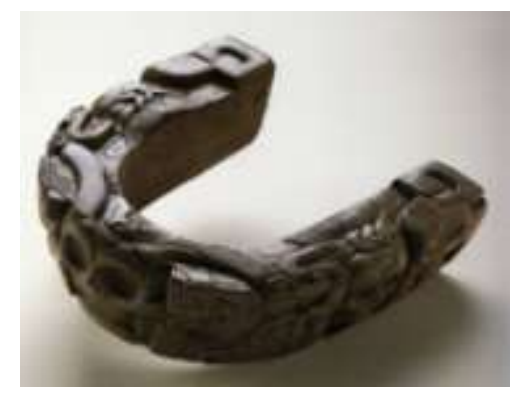

Fuente: Arqueología Mexicana

Fig. 39. Yugo Cerrado con alto y bajorrelieves. Clásico Tardío,Costa del Golfo,Veracruz. Andesita $42 \times 53 \mathrm{~cm}$.

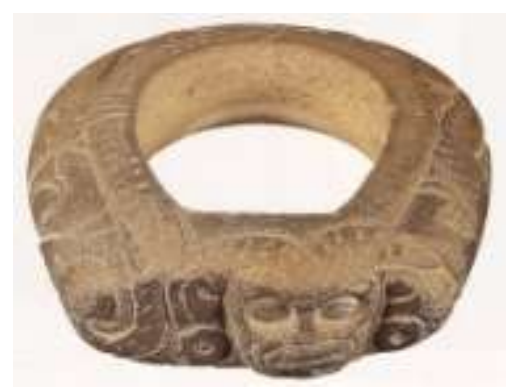

Fuente: Arqueología Mexicana

Fig. 40. Yugo liso con improntas de pies. El Zapotal, Veracruz $42 \times 32.5 \times 10 \mathrm{~cm}$. Piedra gris MAUV.

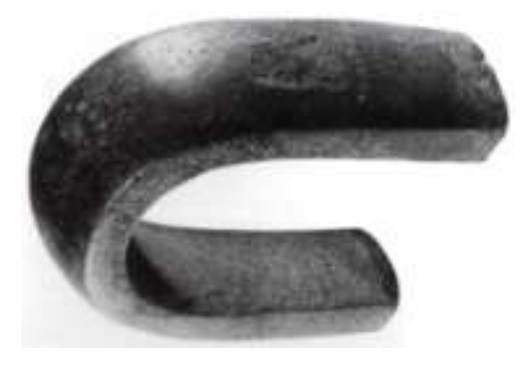

Fuente: The Sport of Life and Death. 
Hachas: El hacha ceremonial son esculturas principalmente de cabezas de hombres, animales o seres sobrenaturales, cuyos rasgos se advierten claramente si se colocan las piezas de perfil, pues estos objetos son muy angostos por la parte frontal (en forma de cuña) y se ensanchan en la parte posterior. El artista tenía que esculpir un relieve en cada una de las dos superficies - de una misma forma y de un mismo tamaño-.

Algunas de estas hachas muestran gran complejidad y plasticidad en su diseño, ya que el área del cráneo o el peinado y su tocado, pueden mostrar a un hombre con un pez, o un personaje de cabeza apoyado sobre sus antebrazos y sus piernas casi tocando su cabeza, envuelto por una serpiente.

El nombre de "hacha ceremonial" proviene de ciertas interpretaciones que hicieron los investigadores del siglo XIX, quienes creían ver en estos objetos la sección pétrea y aguzada de un hacha de combate de carácter ritual, cuyo corte en ángulo suponían que permitían el enmangado con la pieza de madera.

Forma: Por su forma afilada y redondeada al frente, similar a una hacha en la mayoría de los casos, así se conocen; generalmente presentan una terminación recta en su parte posterior seguida de un elemento que sobresale y que se ha sugerido serviria para empotrarla en una pared o en un mango de madera (como las hachas). Al observar estas esculturas se percibe que el escultor trata de adaptar fielmente los 
elementos que intervienen en el diseño a la forma preconcebida de este objeto ritual: el diseño es a la forma.

Formato: Sus dimensiones son variables, ya que pueden ser desde $9.5 \mathrm{~cm}$ de alto (hachas miniatura) hasta aproximadamente $47 \mathrm{~cm}$; el ancho varía desde 9 o $10 \mathrm{~cm}$ hasta $25 \mathrm{~cm}$ o un poco más, el espesor puede ir desde $4 \mathrm{~cm}$ hasta $17 \mathrm{~cm}$ aproximadamente.

Iconografia:

- rostros de guerreros, sacerdotes o jugadores

- cabezas con casco o yelmo en forma de animales

- rostros con decoración facial

- rostros de personas de edad avanzada

- rostros deformados, con características de jaguar, con tocado de pez, con anteojeras del dios Tláloc, cráneo/mono, con huella de pie, cabeza con nariz de ave

- manos

- animales mitológicos: águila, pavo, perro, venado, guacamaya, jaguar, serpientes, iguana, lagartija o salamandra, peces

- Deidades: dios gordo o mofletudo, Tláloc, signo de quincunce 
Posibles usos y simbologia:

- el significado de estas esculturas se relaciona con la ceremonia final del juego de pelota, en la cual ocurría la decapitación del jugador y entonces las hachas simbolizarian las fuerzas y los animales protectores que participaban en este ritual.

- para ser empotradas en un mango de madera, como el hacha actual.

- tienen relación con el sacrificio y la muerte

- profundo simbolismo religioso

Estilo: Se esculpieron en bajorrelieve, principalmente rostros humanos y de animales, sobre la piedra terminada en punta y en ambos lados por igual en simetría. El diseño es naturalista, logrando, en algunos casos, un impresionante realismo y expresividad facial en las caras humanas. En el caso de las cabezas de animales, el diseño es más estilizado, sintético y destacando solo los rasgos fundamentales.

Un recurso innovador utilizado por el artista en algunos casos, es la transparencia visual, esto es que dejan huecos u orificios en la piedra intencionalmente, ya que forman parte de las líneas de la composición, aportando a la pieza escultórica ligereza y dinamismo.

Las líneas son preferentemente de carácter orgánico, onduladas, reforzando el diseño con la doble línea. En el caso de las hachas hay algunos ejemplos en el cual se nota con claridad el estilo de los entrelaces, pero en la mayoría de ellas 
se les da a cada pieza un particular tratamiento formal dependiendo del motivo o elemento a desarrollar conservando siempre la forma ceremonial de este objeto.

A continuación algunos ejemplos de hachas provenientes de la Costa del Golfo:

Fig. 41. Hacha de rostro con casco muy elaborado y con volutas

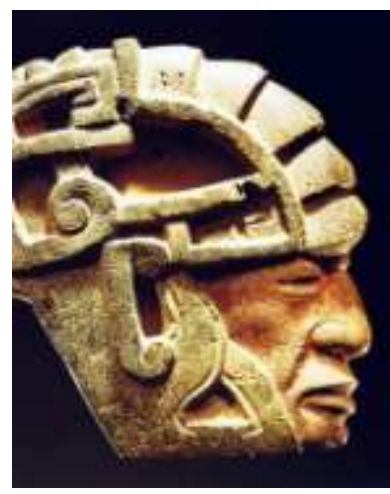

Fuente: Arqueología Mexicana

Fig. 43. Hacha que muestra a un personaje antropomorfo: cuerpo humano y cabeza de ciervo o venado trabajado con líneas dobles

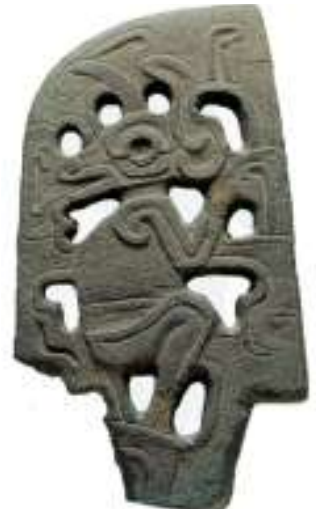

Fuente: www.famsi.org
Fig. 42. Hacha con rostro estilizado

Piedra verde $21.5 \times 17.5 \mathrm{~cm}$

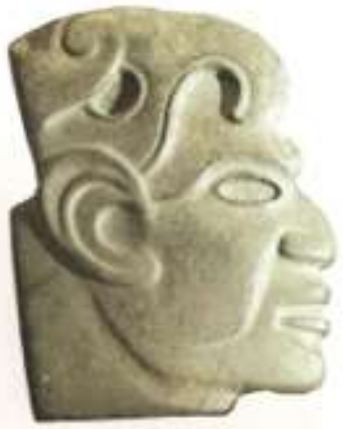

Fuente: Arqueología Mexicana

Fig. 44. Hacha que representa a una guacamaya estilizada; muestra ganchos o volutas estilo Tajín

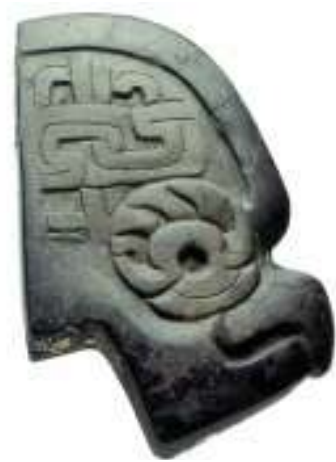

Fuente: www.famsi.org 
Las palmas: Las palmas toman su nombre de la estilizada forma que tienen las hojas de este árbol tropical, sumamente alargadas y que rematan en líneas cortadas a manera de penacho; muchas de las esculturas que llevan su nombre presentan esta silueta, aunque como se verá, existen otros tipos o variantes.

Forma: Su forma característica es la palma, sin embargo existen otros tipos como:

- palmas alargadas y con terminación redondeada en su parte superior esculpida con bajorrelieves estilo Tajin

- palmas alargadas con terminación en una, dos o tres puntas a manera de hojas o plumas con bajorrelieves y con estilo variante

- palmas casi lisas, sin motivos gráficos, alargadas

Formato: Se presentan en formatos que van desde $22 \mathrm{~cm}$ hasta $133 \mathrm{~cm}$ de alto.

Iconografia:

- personajes humanos arrodillados

- personajes antropomorfos descendentes

- sacerdotes, guerreros, sacrificados

- personajes con cetro y sentados en un trono

- manos 
- animales mitológicos: cocodrilo o lagarto, zopilote, águila, aves estilizadas, perro, coyote, venado o ciervo, lagartija, mono

- mazorcas de maíz

- palmas, cuchillos de sacrificio, cuerdas

- el tachtli o campo de pelota

- signo de ollín

Posibles usos y simbologia:

- reproducción en piedra de los broches ceremoniales con que los jugadores de pelota cerraban por el frente sus cintos de cuero

- simbolizaban el elemento celeste y el diurno (plumas de ave)

Estilo: Estilo Clásico Veracruzano o estilo Tajín en su mayoría. Figuras con tratamiento naturalista, así como estilizadas, atendiendo a la forma palmeada. En algunos casos se saturan los espacios creando piezas con redundancia visual. Se utiliza la simetría para lograr un diseño equilibrado y al mismo tiempo marcar un antagonismo propio del enfrentamiento entre dos equipos dentro del campo sagrado de pelota. Se complementan a la composición elementos sígnicos con doble linea, ganchos $\mathrm{y}$ entrelaces que sirven de fondo para el personaje central. 
A continuación ejemplos de palmas de variados diseños y formas procedentes de Veracruz:

Fig. 45. Palma integrada por 3 secciones individuales representan cuchillos de sacrificio unidos, por una cuerda ritual, que sostiene 4 manos.

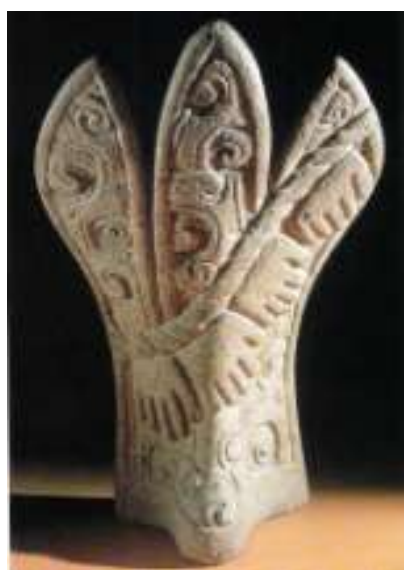

Fuente: geocities.com

Fig. 46. Palma, Veracruz Retrato de jugador con enorme tocado con volutas/Justin Kerr Collection

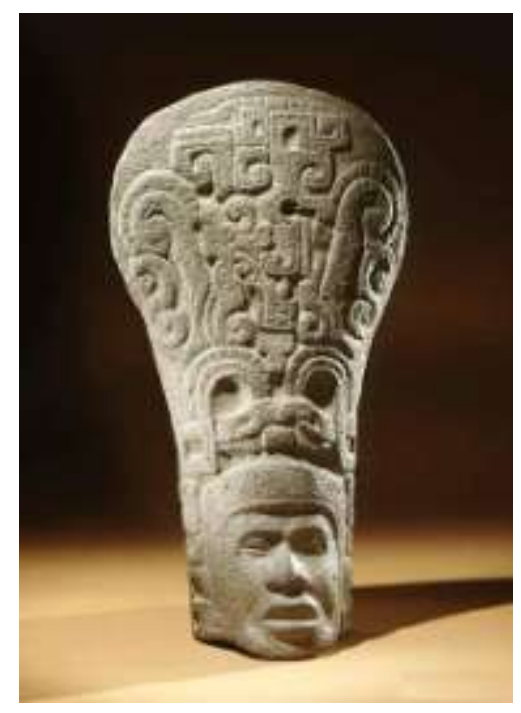

Fuente: Justin Kerr Collection www.famsi.org
Fig. 47. Palma cocodrilo. Costa del Golfo/piedra. $66 \times 22.9 \times 13 \mathrm{~cm}$

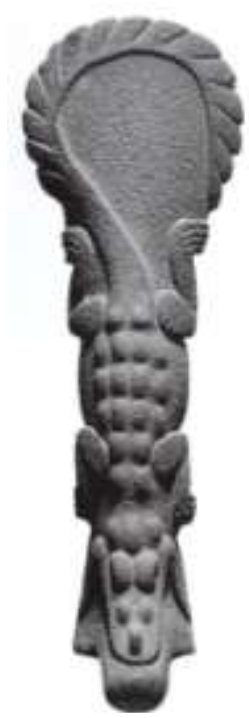

Fuente: The Sport of Life and Death 
Además del complejo lítico que se ha descrito, en esta zona costeña se han encontrado estelas labradas; las estelas son grandes bloques de piedra hechos de una sola pieza. Su forma es rectangular y están decoradas sobre una o todas sus caras, y muy rara vez en bulto redondo.

Se suele representar personajes masculinos de pie ricamente ataviados, que, a veces, están acompañados por personajes secundarios como cautivos, mujeres, enanos, niños, animales y personajes sobrenaturales. El material más usado es la piedra caliza y sus dimensiones varían mucho según el sitio de origen. Pueden tener una altura promedio de 1,5 a 2,5 m.

Las escenas suelen tener inscripciones jeroglificas que cubren el resto de la estela. Las inscripciones contienen fechas de hechos históricos y los nombres y títulos de los individuos representados. Pueden también informarnos sobre una dinastía real, sus alianzas matrimoniales, sus victorias, derrotas y hasta la historia de una ciudad durante más de un siglo.

Fig. 48. Jugador de Pelota, relieve en piedra arenisca de El Tajín Fase Cacahuatal, 350-600 d. C. Veracruz

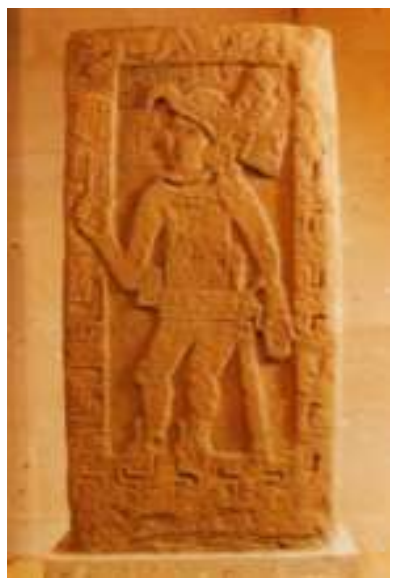


En la lápida encontrada en la cancha del Juego de Pelota en Aparicio, Veracruz, muestra un relieve, magníficamente conservado, de un personaje sentado en lo alto de una escalinata, de cuyo cuello cercenado surgen siete serpientes entrelazadas. Este personaje representa sin duda un jugador de pelota, pues su indumentaria está formada por todos los implementos del juego: lleva en la cintura una protección de caucho, brazaletes, collares y tobilleras; a la derecha se ve una palma del estilo alas de murciélago y en una mano lleva una manopla, lo que indica una de las variantes del juego.

Fig. 49. Lápida de Aparicio Aparicio, Veracruz Clásico Piedra 121 X $52.3 \mathrm{~cm}$.

Fuente: www.arqueomex.com

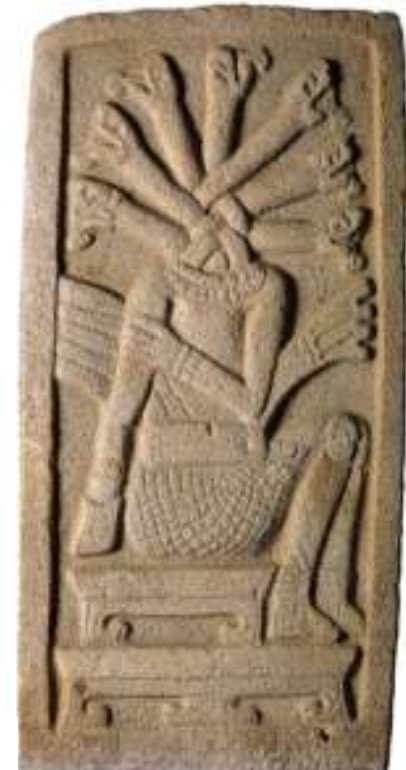

De todo lo visto se desprende una idea general acerca de las culturas asentadas en tiempos anteriores al surgimiento de la cultura de El Tajín y de sus magníficos restos escultóricos, cerámicos y arquitectónicos en los cuales es evidente la influencia de otras culturas importantes como la olmeca, 
maya, teotihuacana, pero logrando un caracter propio: el estilo de las culturas de la Costa del Golfo denominado por T. Proskouriakoff Estilo Clásico Veracruzano o Estilo Tajin que, es el que utiliza el recurso gráfico de la continuidad visual en una composición en la que sus elementos se entrelazan, se relacionan unos con otros utilizando volutas y ganchos redondeados, orgánicos, a veces perfilados con doble línea y cargados de simbolismo religioso de carácter abstracto relacionándolo con la representación del agua, el aire, el movimiento, o la deidad suprema Quetzalcoatl. Y esto se evidencia con mayor frecuencia en el complejo de yugoshachas-palmas adaptándolo a diversos formatos sin perder la esencia del mismo. 


\section{LA CULTURA DE EL TAJIN}

Se puede vislumbrar entonces que la cultura del Tajin es el producto de la herencia cultural de los diversos pueblos que transitaron durante varios siglos en la Costa del Golfo de México, propiciada también por el intenso intercambio comercial, social y cultural entre la zona sureste costera ocupada por los mayas del Clásico y más allá de las fronteras mexicanas, con la zona del altiplano central de Teotihuacan.

El Tajin, por lo tanto, participa del dinamismo ideológico, artístico, religioso, político, propio de todas las grandes culturas de Mesoamérica; su arte y arquitectura son testimonios de la conjunción de elementos de varias culturas que, amalgamados, dieron como resultado una expresión propia y original. Paul Westheim, quien consideraba totonaca a la cultura de El Tajín, lo expresa de esta manera:

Ninguna de las altas culturas
mesoamericanas revela en su aspecto
arqueológico tantas influencias como la
totonaca. Pueden constatarse en ella,
claramente discernibles, rasgos
característicos del arte olmeca, huasteca,
teotihuacano, tolteca, maya y de otras
culturas más, sin hablar del último
periodo, el de Cempoala, en que los
totonacas llegaron a ser satélites de los




\begin{abstract}
aztecas. Pero sin embargo supieron crear una arquitectura original, un estilo artístico muy suyo, en suma: una cultura propia, que se distingue, independiente $\mathrm{e}$ inconfundible, de aquellas otras civilizaciones. Basta señalar la gran pirámide del Tajín, con los nichos "que son propios de esta cultura”. ${ }^{22}$
\end{abstract}

De igual forma, El Tajín representa una influencia cultural muy importante para varios sitios de Mesoamérica (La Ventilla Teotihuacan, Cholula, Chichén Itzá, Morgadal Grande, etc.), convirtiéndose en la "ciudad más culta del oriente de Mesoamérica"23. Su elevado número de canchas para el juego de pelota (17 hasta ahora encontradas) refuerzan su posición de prestigio, realizándose ritos y ceremonias anuales relacionadas con el Juego de Pelota en las que participan distintos representantes.

\title{
3.1 Ubicación geográfica
}

La zona arqueológica de El Tajín se encuentra ubicada en la parte centro-norte del actual Estado de Veracruz, a $14 \mathrm{~km}$ del municipio de Papantla, así como también se encuentra aproximadamente a $16 \mathrm{~km}$ de la ciudad de Poza Rica.

\footnotetext{
${ }^{22}$ Westheim, Paul, Ideas fundamentales del arte prehispánico en México, México, Ediciones Era, S.A. de C.V., 1972, pág. 261

${ }^{23}$ Pascual Soto, Arturo, Tajín, en busca de los orígenes de una civilización, México, D.F., UNAM, Instituto de Investigaciones Estéticas, 2006, pág. 19
} 
La antigua ciudad prehispánica de El Tajín alcanza en su período de auge unas 144 hectáreas de edificaciones, algunas de ellas construidas sobre terreno plano en la parte central, y otras sobre pequeñas lomas. El terreno es una cuenca ocupada por lomeríos con pronunciadas terrazas escalonadas que descienden de nivel en dirección norte-sur con un desnivel máximo de $62 \mathrm{~m}$ y está delimitado por dos arroyos con escaso caudal que fluyen hacia el río Tlahuanapa, afluente del Tecolutla. A pesar de que la región está comprendida entre los ríos Cazones hacia el norte y Tecolutla al sur, y relativamente a poca distancia de ellos, la zona no cuenta con agua suficiente. En la antigüedad contaba con un bosque exuberante de selva tropical, que permitia abundantes cosechas, principalmente de vegetales y frutales, así como de cacao y en particular de vainilla (vainilla planifolia), planta aromática muy apreciada en la gastronomía, siendo reconocida esta zona por su magnifica calidad.

Actualmente sobreviven algunas especies vegetales de ese antiguo ecosistema como ceibas, copalillo, jaboncillo, ojite, espino blanco, orejón, palo de rosa, y varias más. En cuanto a la fauna, propia de la selva, están los venados, liebres, ardillas, palomas, gavilanes, pericos, colibries, garzas, serpientes, ranas, etc.

Las coordenadas de El Tajín, determinadas por el ingeniero topógrafo Germán Cervantes sobre la Pirámide de los Nichos el 
21 de Mayo de 1984, son: $20^{\circ} 28^{\prime} 35^{\prime \prime}$ de latitud norte y $97^{\circ} 22^{` 3} 9^{\prime \prime}$ de longitud oeste. ${ }^{24}$

El clima de esta región, según la clasificación Köppen Geiger es tropical cálido-húmedo de tipo senegalés (AWA), con precipitaciones durante todo el año, independientemente de las lluvias estacionales entre los meses de junio y octubre. La precipitación anual es de $1000 \mathrm{~mm}$ y la temperatura varía entre $7^{\circ} \mathrm{C}$ y $40^{\circ} \mathrm{C}$ con una media anual de $25^{\circ} \mathrm{C}$.

La región corresponde a la parte sur de la provincia denominada Cuenca Tampico-Misantla, del noreste de México. Está formada por lutitas y margas de color gris oscuro, con espesor de intemperización de entre 8 y $17 \mathrm{~m}$, que constituyen

Fig. 50. Ubicación de la zona arqueológica de El Tajín en el mapa de la República Mexicana y en detalle de la Costa del Golfo de México

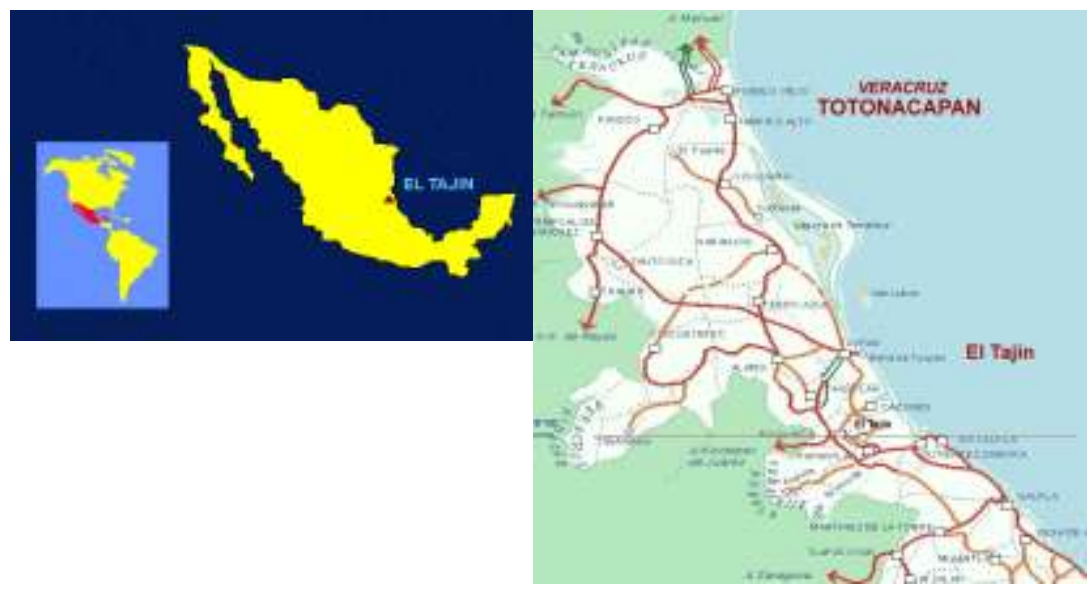

Fuente: www.arqueomex.com

${ }^{24}$ Ladrón de Guevara, Sara, Imagen y Pensamiento en El Tajín, Xalapa, Ver. México, Universidad Veracruzana, 2005, pág. 26 
la Formación Coatzintla del Oligoceno Superior. La región es una de las más antiguas del país y de ella se extraen hidrocarburos. ${ }^{25}$

La ciudad prehispánica tiene una altitud respecto al nivel del mar de entre 140 y $200 \mathrm{~m}$, y se localiza a unos $50 \mathrm{Km}$. del Golfo de México.

La pendiente norte-sur donde se erige la ciudad provoca la presencia de los dos arroyos que constituyen el limite natural este-oeste del área arquitectónica-monumental. No obstante, existieron otros conjuntos arquitectónicos menores y áreas habitacionales en sus alrededores, pertenecientes a la antigua población de El Tajín.

Fig. 51. Representación gráfica de la zona arqueológica de El Tajín extraída de la revista México Desconocido “El Tajín” núm.6, Mayo 2003

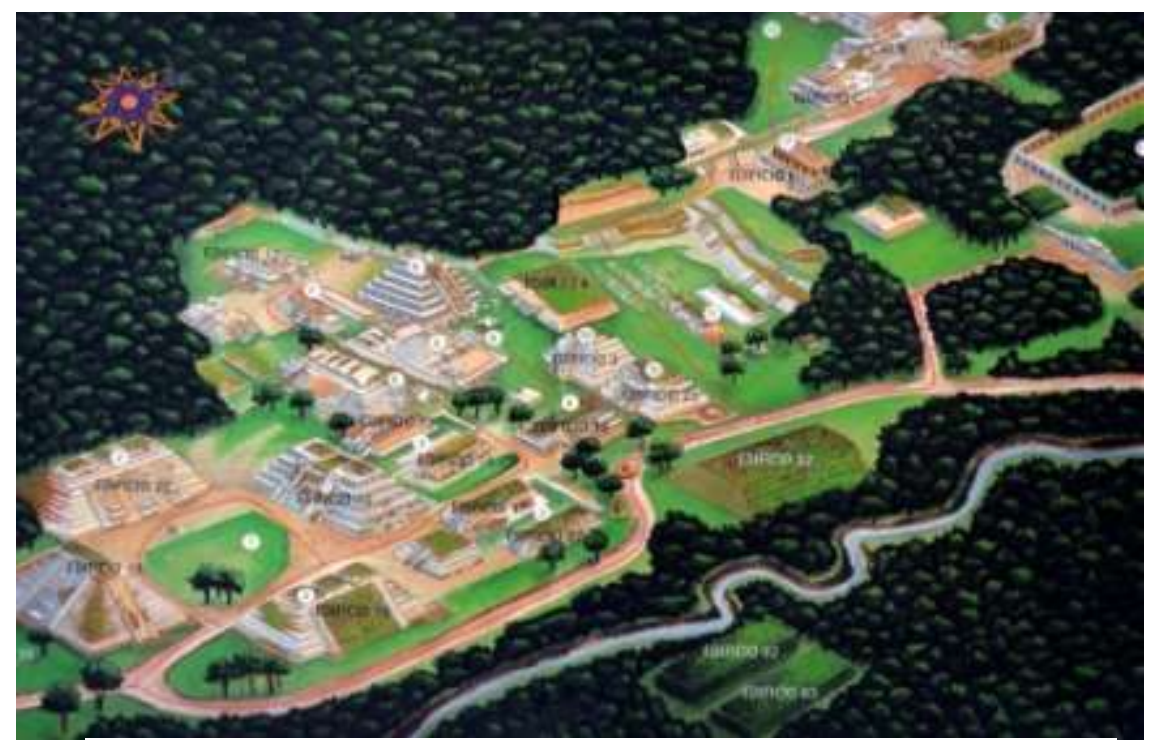

Fuente:Revista México Desconocido “El Tajín” núm.6, Mayo 2003

25 Ladrón de Guevara, Sara, Imagen y Pensamiento en El Tajín, Xalapa, Ver. México, Universidad Veracruzana, 2005, pág. 26 


\section{2 Arqueologia general e historia del sitio.}

A finales del s. XVIII, El Tajín se encontraba oculto bajo una espesa vegetación, propia de la selva tropical; en esa tierra fértil, los habitantes totonacas habían subsistido durante años viviendo del cultivo y sabiendo de la existencia de los antiguos edificios y templos pertenecientes a sus antepasados, sin revelarlos jamás a español alguno. Desde su abandono (s. XIII) y hasta su "re-descubrimiento, hubieron de transcurrir alrededor de 550 años, hasta que, en cierta ocasión, haciendo un recorrido por la zona de El Tajín en busca de sembradíos de tabaco clandestino, don Diego Ruiz, "Cabo de Ronda del Tabaco", durante la época de la colonia española, encontra la Pirámide de los Nichos; este acontecimiento fue publicado en el diario La Gazeta de México el 12 de julio de 1785. Esta noticia despierta el interés del sacerdote jesuita P.J. Márquez, quien en 1804 publica en la ciudad de Roma una obra con ilustraciones de la pirámide (la cual nunca conoce), titulada: Due antichi monumenti di architettura messicana; basa sus conocimientos de la misma en la nota que publicara la Gazeta de México sobre el hallazgo de don Diego Ruiz.

En el año de 1811, Alexander von Humboldt, publica su Essai Politique sur le Royaume de la Nouvelle Espagne, en el cual da a conocer que el señor Guillermo Dupaix había visitado la 
Fig. 52. Grabado que acompaña a la publicación de Pedro José Márquez (1804) sobre la Pirámide de los Nichos

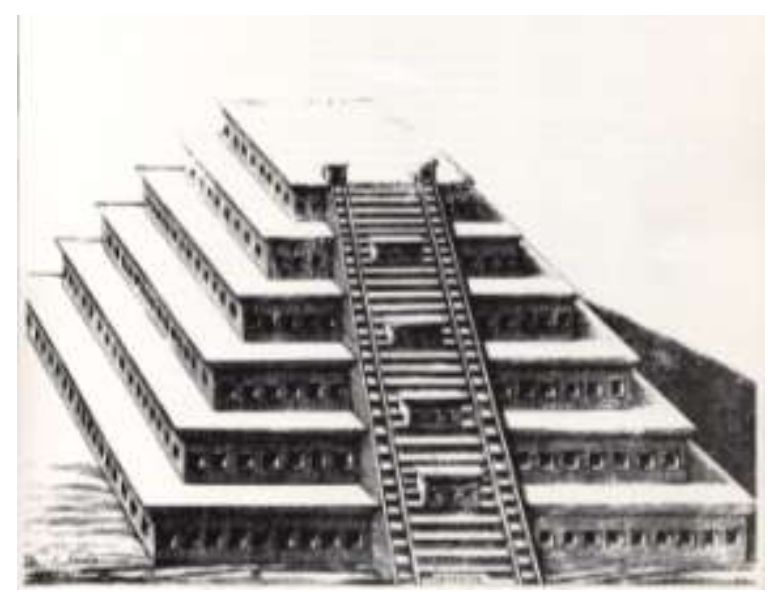

Fuente: Iconografía arqueológica de El Tajín.

pirámide de Papantla ofreciendo nuevos datos que corrigen las anteriores descripciones de la pirámide:

El señor Dupaix...ha visitado la pirámide de Papantla; ha examinado cuidadosamente el corte de las enormes piedras con que está construída; y ha sacado diseños de los jeroglíficos de que se hallan cubiertos;...La estampa que en 1785 se publicó en la Gazeta de México es muy imperfecta.

...La base de la pirámide es exactamente cuadrada; cada costado tiene 25 metros de largo; la altura perpendicular apenas parece ser de 16 a 20 metros...Una escalera principal de 52 grados conduce a la cima truncada del teocalli...El revestimiento de 
las hiladas de piedras está adornado con jeroglíficos, entre los cuales se distinguen serpientes y cocodrilos esculpidos en relieve. ${ }^{26}$

El viajero Karl Nebel viaja a México entre los años 1829 a 1834, durante los cuales se dedica a recorrer el país realizando dibujos de paisajes, costumbres, etc. y que publica en 1840 conteniendo una litografia de cómo ve la Pirámide de los Nichos en medio de la selva tropical.

Fig. 53. Litografía realizada por Karl Nebel de la Pirámide de los Nichos en 1836.

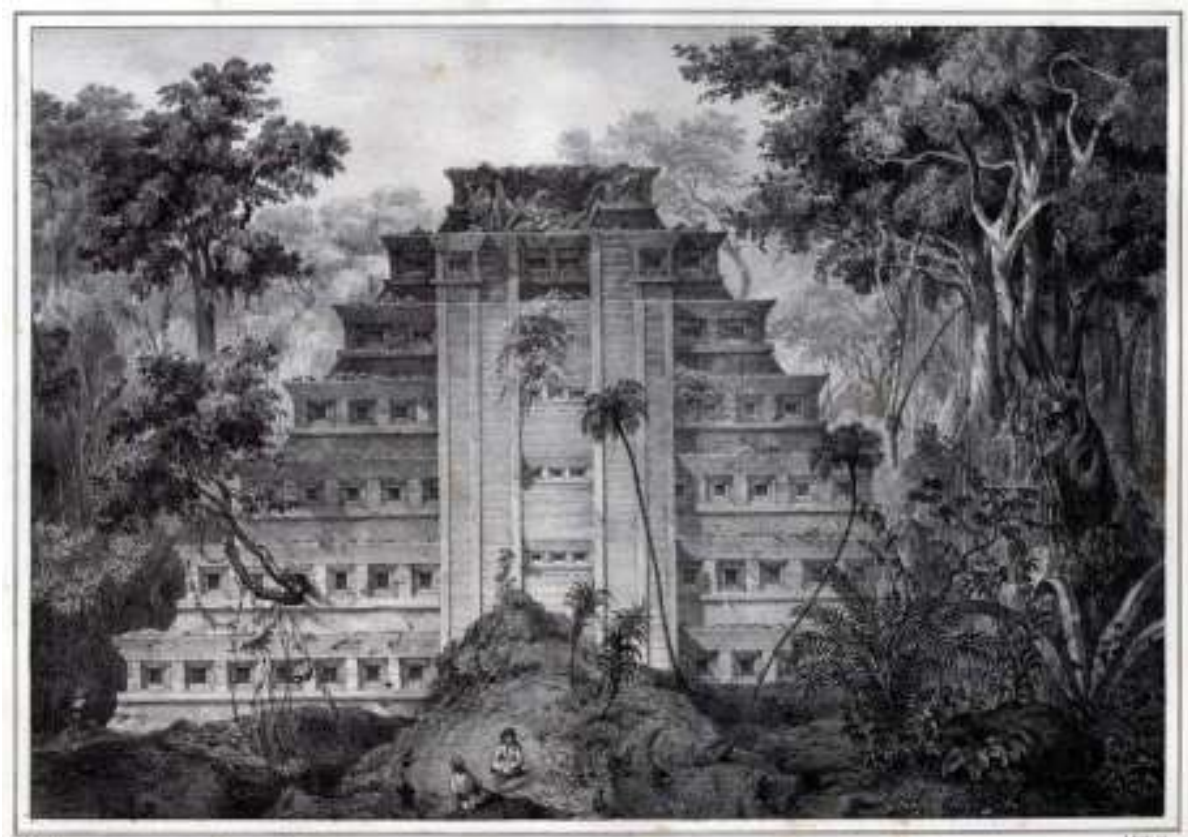

Fuente: www.bluffton.edu/.../eltajin/eltajinintro.html

${ }^{26}$ Citado por Piña Chan, Román/Castillo Peña, Patricia, Tajín, la Ciudad del Dios Huracán, México, Fondo de Cultura Económica, 1999, págs. 8 y 9. 
Francisco del Paso y Troncoso, director del Museo Nacional de México en 1889, estudioso de la historia mexicana e impulsor de publicaciones del Museo, publica "Arqueología Mexicana. Las Ruinas de Cempoala y el templo de El Tajín explorados por el director del Museo Nacional de Arqueología, Historia y Etnología en misión en Europa”, Anales del Museo Nacional de México, 3ª Época, Vol. III, México, 1911.

El destacado antropólogo, etnógrafo, lingüista, Eduard Seler publica, en 1908, Eine Steinfigur Aus der Sierra von Zacatlan, donde hay ilustraciones de esculturas del sitio.

Todos estos datos anteriores corresponden a las primeras noticias que se tuvieron del lugar, dando referencias sobre la Pirámide de los Nichos principalmente, y realizadas por las personas que hicieron expediciones a El Tajin, sin llevar a cabo trabajos arqueológicos. Durante este periodo, que se puede denominar pre-arqueológico, se registraron ilustraciones, como las mencionadas, y fotografias dentro de las cuales se encuentran las tomadas por Teobert Maler y Fewkes que publicaron en Certain Antiquities of Eastern México en 1907.

Hacia el año de 1924, Gabriel García Velázquez, ayudante técnico de la Secretaría de Agricultura y Fomento inicia una temporada en El Tajín con el objetivo de la conservación de la Pirámide de los Nichos, con trabajos de intervención y consolidación.

En 1929 Herbert J. Spinden y su esposa Ellen conocen El Tajin. Realizaron investigaciones sobre el arte del lugar y, 
posteriormente, publicaron en un breve informe en el Congreso de Americanistas en 1930. Posteriormente, en 1933, Ellen S. Spinden publica The Place of Tajin in Totonac Archaeology. En esta publicación ofrece datos importantes sobre la Pirámide de los Nichos, como por ejemplo que tiene 365 nichos que coinciden con el año solar y que, además, se encontraban rodeando a la pirámide lápidas con bajorrelieves, entre ellas un Tláloc con el símbolo del año. Otros datos que da son la existencia de un altar proveniente de la zona conocida como Tajín Chico; encuentra una especie de arco; habla del edificio de las Columnas con tambores de bajorrelieves, 2 juegos de pelota (el del suroeste) con paneles en bajorrelieves observando similitudes con los del campo de pelota de Chichén Itzá.

En 1932 Enrique Juan Palacios y Enrique Meyer publican La ciudad arqueológica de El Tajín y sus revelaciones, en el que hacen descripciones sobre lo que observan en la arquitectura y escultura, para dar su interpretación sobre la iconografia y la religión de esta cultura. Así, por ejemplo, describen los bajorrelieves del Juego de Pelota Sur:

\begin{abstract}
Abundan lápidas esculpidas en fino bajorrelieve... Hay un motivo entrelazado con volutas que se descogen y recogen sobre sí mismas en estilización peculiar y elegantísima (rizos de plumas de la serpiente preciosa: Gran dios serpentiforme
\end{abstract}


relacionado con el cielo y el aire, con la lluvia y la fertilidad). Dios de la vida.

Las volutas entrelazadas representan las ondulaciones del cuerpo de la preciosa serpiente. ${ }^{27}$

En 1934, la Dirección General de Monumentos Prehispánicos de la Secretaría de Agricultura y Fomento comisiona a el ingeniero topógrafo Agustín García Vega para realizar diversos trabajos entre los cuales están:

- desmonte del Tajín Chico y Columnas

- levantamientos topográficos

- inicio de la exploración de la Pirámide de los Nichos: encontró lápidas con bajorrelieves las cuales fueron estudiadas por Enrique Juan Palacios

- reconstrucción de 6 nichos del lado noreste de la pirámide

- se inicia el proceso de armar los bloques con bajorrelieves del Juego de Pelota Sur

- en los años 1935 a 1937 se sigue con el levantamiento del plano general de lo conocido

- se hace la reposición de otros nichos

- se exploran los edificios A,B y C del Tajín Chico

- el arqueólogo Wilfrido du Solier realiza estudios de cerámica y estratigrafia

27 Citado por Piña Chan, Román/Castillo Peña, Patricia, Tajín, la Ciudad del Dios Huracán, México, Fondo de Cultura Económica, 1999, pág. 10 
A partir de todo esto, la ciudad comienza a surgir de la espesa vegetación que la mantenía oculta.

En 1938, comisionado por la Dirección General de Monumentos Prehispánicos llega a El Tajín, el reconocido arqueólogo José García Payón, cuyos trabajos que a partir de su llegada continuaron hasta su muerte, fueron fundamentales para la construcción y rescate de la historia de El Tajin. Con disciplina y entrega investiga, explora y restaura gran parte de la zona arqueológica. A continuación algunas de sus acciones en el sitio:

- para conocer el sistema constructivo y comprobar si había estructuras anteriores, excava un túnel en el lado occidental de la Pirámide de los Nichos, la cual es el primer edificio trabajado por García Payón, por su gran deterioro. Completa su restauración y encuentra además tableros y almenas del Templo Superior que se encontraba sobre la pirámide.

- en 1940 exploró los edificios 2 y 5, hallándose en el Edificio 5 el monolito poligonal del Dios Tajín, el cual se encuentra actualmente allí.

- explora el Edificio de las Columnas, el cual considera el más importante de la zona por su altura, extensión y ubicación; sin embargo, no llega a restaurar este edificio. Sólo se realiza el traslado de los fustes de las columnas con bajorrelieves.

- restaura los edificios principales del Tajin Chico. 
- levanta el plano de lo explorado.

- construye la bodega-museo de la zona y la adecúa para ser visitada por los turistas.

Los trabajos de García Payón continúan en temporadas realizadas hasta 1963. El resultado de estos se encuentran en informes, artículos y publicaciones.

Fig. 54. Fotografía de archivo propiedad de José García Payón, El Tajín en 1938.

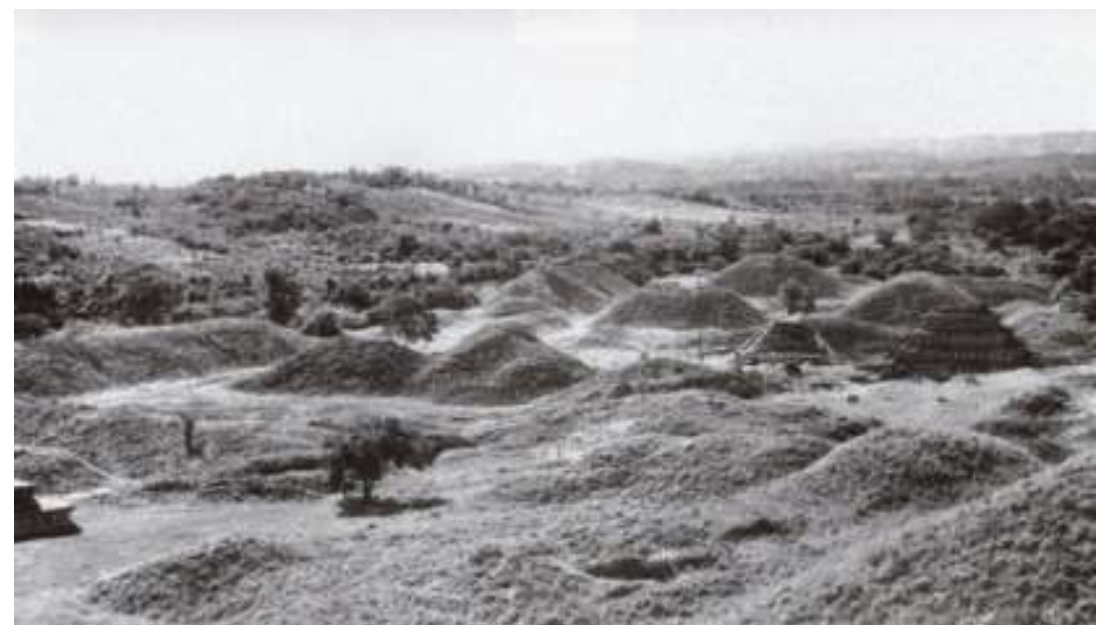

Fuente: Tajín, la ciudad del Dios Huracán

Fig. 55. Fotografía de las columnas con bajorrelieves como las encontró García Payón.

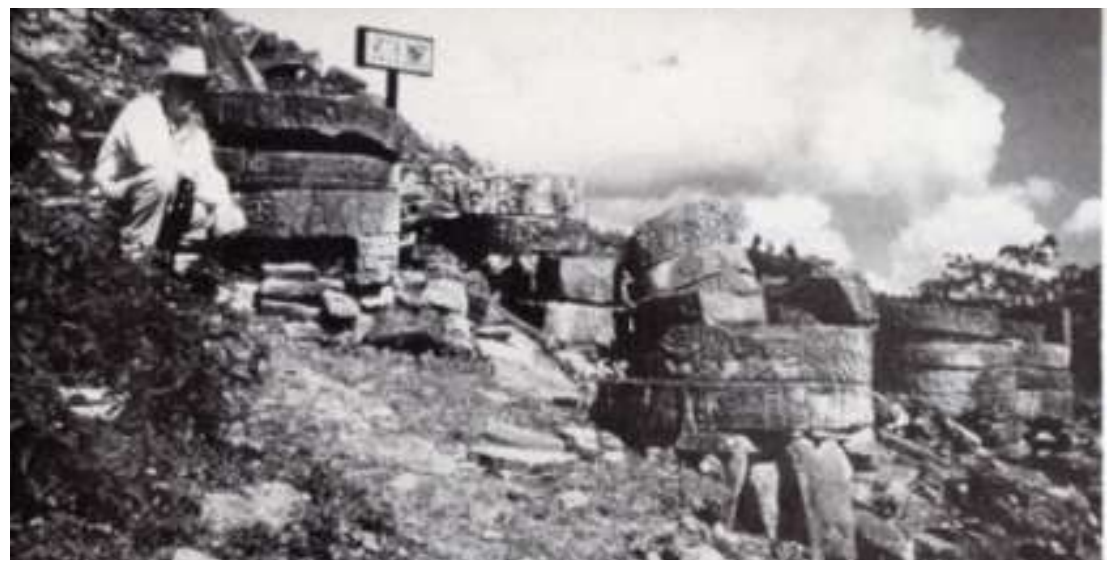

Fuente: Guía oficial de El Tajín, INAH 
En 1964 el arquitecto Ignacio Marquina publica Arquitectura Prehispánica donde hace mención de la arquitectura y escultura de El Tajín, además de reunir los planos, fachadas, cortes y detalles constructivos de los principales edificios realizados por García Payón.

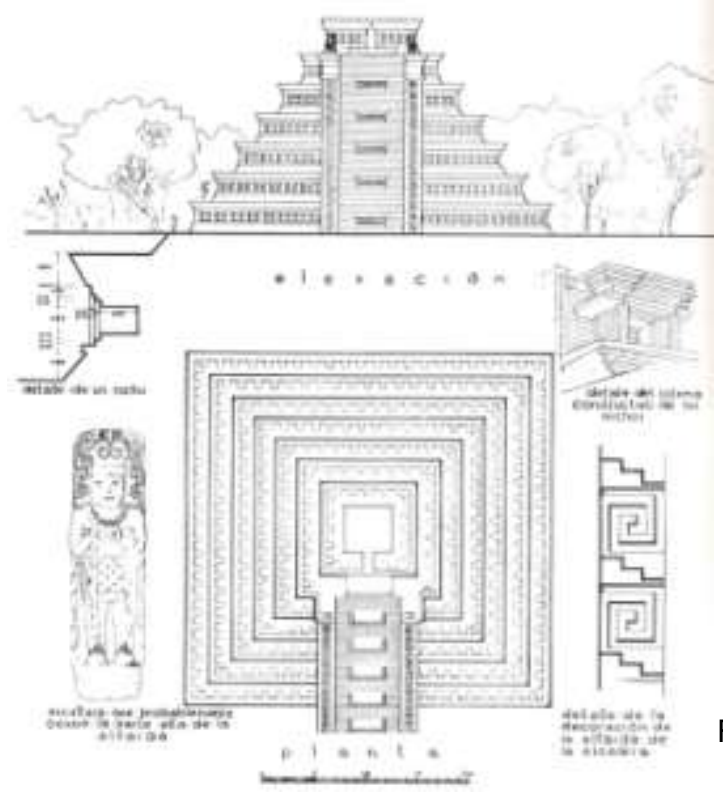

Fig. 56. Fachada, planta y detalles arquitectónicos y escultóricos de la Pirámide de los Nichos, realizados por el arquitecto José García Payón publicados en Arquitectura Prehispánica

Fuente: Arquitectura Prehispánica

En 1973, la Dirección de Monumentos Prehispánicos, junto con el Instituto de Antropología de la Universidad Veracruzana, dirigido por Alfonso Medellín Zenil, realiza la delimitación de la zona arqueólogica. Por su parte, el ingeniero G.R. Kroster y su esposa, la arqueóloga Paula Kroster, auspiciados por la Fundación Wenner-Green, realizan el plano topográfico. Paula Kroster establece una cronología basada en sus estudios sobre la cerámica del sitio. 
En 1975 se publica Arquitectura mesoamericana, de Paul Gendrop, donde se mencionan aspectos de la arquitectura y escultura de El Tajín.

En 1978-1979, el Instituto Veracruzano de Antropología comisionó a un equipo de técnicos en restauración para intervenir en la limpieza y conservación de los relieves del Juego de Pelota Sur.

De 1981 a 1983 el arqueólogo Ariel Valencia, auspiciado por la Dirección de Monumentos Prehispánicos, se dedicó a labores de mantenimiento de la zona.

En 1984 comienza el Proyecto Tajín bajo la coordinación del doctor Jüergen K. Brüeggemann que nace de un convenio entre el gobierno del Estado de Veracruz y el Instituto Nacional de Antropología e Historia (INAH), con la participación de la Universidad Veracruzana, cuyo representante es el arqueólogo Alfonso Medellín Zenil. Además, participa un equipo interdisciplinario compuesto por antropólogos, arqueólogos, arquitectos, restauradores, conservadores, etc.

Algunos de los diversos trabajos realizados durante el Proyecto Tajin:

- En diferentes grados, se intervinieron 27 edificios nuevos de la zona, los cuales se consolidaron y restauraron parcial o totalmente. 
- Se realiza el catálogo de la escultura anteriormente encontrada y la hallada durante las exploraciones.

- Se hace la limpieza de las pinturas murales encontradas en algunos edificios procurando su conservación.

- Se construyeron geodrenes que sirven para drenar las aguas que bajan de norte hacia el sur y que inundaban anteriormente los edificios cuando llovía fuertemente.

- Se llevan a cabo estudios estratigráficos de la zona y sitios vecinos.

- Se realiza el análisis urbano-arquitectónico del lugar y otros trabajos como estudio de restos óseos hallados, etc.

- Se levanta el Museo del Sitio, que es diseñado y construido por el prestigioso arquitecto Teodoro González de León. En el museo destacan las columnas procedentes del Edificio de las Columnas y varios de los relieves, en los que se explica la celebración de los ritos más significativos de El Tajín.

El doctor Jüergen K. Brüeggemann aporta los siguientes datos numéricos durante el Proyecto Tajín:

*La antigua ciudad de Tajín se ubica en el norte del estado de Veracruz a $20^{\circ} 28^{\prime} 35^{\prime \prime}$ latitud norte y $97^{\circ} 22^{\prime} 39^{\prime \prime}$ longitud oeste. *Se desarrolla entre los siglos VIII Y XIII d.C. Ocupa una superficie poblada de 196 
ha; y contaba con una población de entre 15 mil y 20 mil habitantes.

*E1 asentamiento urbano se subdivide en cinco barrios.

*Se han contabilizado 168 edificios de carácter público, 27 templos, 17 canchas para el Juego de Pelota, 58 residencias, tres altares y 46 casas-habitación identificadas; en total se construye una superficie de 105,555 metros cuadrados, 22,129 de ellos para Juegos de Pelota, 464 para altares, 44,817 para templos y 3,688 para casas conurbadas (identificadas).

* La altura de los edificios, en el caso de los altares, puede variar entre dos y tres metros, los templos entre dos y 21 m., las residencias entre 1 y $10 \mathrm{~m}$ y las casas conurbadas entre medio y $2 \mathrm{~m}$.

*E1 Edificio 1, conocido como Pirámide de los Nichos por tener 365 nichos, cuenta con un tiro prehispánico de $14 \mathrm{~m}$ de profundidad que baja de la parte superior del basamento hasta el segundo cuerpo. El corpus escultórico en piedra consta de 190 piezas entre fragmentos y piezas enteras. *En la pintura mural contamos con seis murales relativamente completos, 121 fragmentos policromados y 2,898 fragmentos monocromos. 
*El contenido de las pinturas, a diferencia de las de Las Higueras, es altamente simbólico.

*El Proyecto Tajín se desarrolla entre los años 1984 y 1985 y entre 1988 y 1992. *Restaura, contando pastos, empedrados y edificios, una superficie de 24 ha; analiza y maneja aprox. 700 mil fragmentos cerámicos, 453 artefactos de obsidiana, 15 artefactos de piedra pulida y 51 figurillas de barro.

*Hasta la fecha se han realizado 90 informes técnicos de campo entregados en 30 tomos, que constan de 3689 cuartillas y 3989 ilustraciones, así como 15 publicaciones entre artículos y libros.

*El equipo de trabajo ha presentado 17 ponencias en cuatro congresos internacionales.

*La última temporada, de 1988 a 1992, tuvo un costo de 11,6 millones de nuevos pesos y trabajaron 500 obreros, 42 técnicos y 18 investigadores.

*La zona arqueológica cuenta con un museo de sitio, restaurante, cafetería, locales comerciales y servicios sanitarios. ${ }^{28}$

${ }^{28}$ Brüggemann, Jürgen K, Tajín en Números, en Arqueología Mexicana, México, Editorial Raíces, S.A. de C.V. Vol. 1, Núm. 5, Dic. 1993-Enero 1994, pág.57 


\subsubsection{Nombramiento como Patrimonio de la Humanidad.}

A partir de todos los esfuerzos realizados por las diferentes instituciones nacionales y extranjeras en la zona arqueológica de El Tajín y de la permanente presencia del Instituto Nacional de Antropologia e Historia durante los años mencionados en el apartado anterior, el 14 de diciembre de 1992 la Organización de las Naciones Unidas para la Educación, la Ciencia y la Cultura (UNESCO) reconoce la importancia de El Tajín, inscribiendo el sitio en la Lista de Bienes Patrimonio Cultural de la Humanidad.

Por su parte, el gobierno del Estado de Veracruz, debido a la trascendencia de esta zona, emanada del conocimiento del desarrollo cultural del norte del estado de Veracruz y de toda Mesoamérica, propicia que el Titular del Ejecutivo Federal emitiera una Declaratoria de Zona de Monumentos Arqueológicos para El Tajín, publicada el 30 de marzo de 2001 en el Diario oficial de la Federación. Derivado de esta acción gubernamental, el Centro INAH-Veracruz lleva a cabo diversas acciones de información acerca de los alcances de dicha declaratoria para delimitar la zona arqueológica -con una superficie total de 1221 hectáreas-, que incluye las áreas de monumentos prehispánicos, las zonas habitacionales y de cultivo, terrazas y sistemas hidráulicos.

El Tajín es visitado anualmente por 1 millón de turistas aproximadamente; cuenta además con un Parque Temático y 
un Centro de las Artes Indígenas situados a un costado del sitio, lugares en donde se organizan diversas actividades como talleres, cursos, conferencias, producción y venta de artesanías indígenas, etc.

\subsection{Etapas de desarrollo urbano de la zona arqueológica de E1 Tajin.}

Como se recordará, se desconoce el grupo cultural que iniciara la ocupación de El Tajín, así como la fecha exacta del inicio de su urbanización; sin embargo, se comparte la opinión de algunos investigadores acerca de que esta cultura es el producto del tránsito de varios grupos humanos desde el período Formativo provenientes de la costa del Golfo. Estos grupos, en algún momento dado, iniciaron la ocupación de El Tajín entre el año 200 y 300 d.C. (período Clásico Temprano), fecha también debatida durante mucho tiempo, en que se creía era muy posterior, es decir, del año 600 d.C. (Clásico Tardío). El arqueólogo Arturo Pascual Soto, quien tras 10 años de investigación, ha encontrado evidencias arqueológicas al respecto, expone en su más reciente publicación:

...El Tajín ya sería una ciudad activa, con características culturales propias, en el Clásico temprano, puesto que hemos recuperado en el Cerro del Oeste un grupo de cerámicas pertenecientes a este período, 
entre las cuales destaca el fragmento de un soporte rectangular inciso correspondiente a un vaso trípode cilíndrico modelado durante la fase Cacahuatal (ca. 350-600 d.C.). Por otra parte, sabemos del hallazgo de un respaldo de espejo, probablemente labrado en el centro-norte de Veracruz y luego depositado en una tumba de Kaminaljuyú, en los Altos de Guatemala, como parte de una ofrenda funeraria de la fase Esperanza. ${ }^{29}$

Fig. 57. Soporte rectangular de vaso trípode cilíndrico, Fase Cacahuatal (350-600 d.C.).
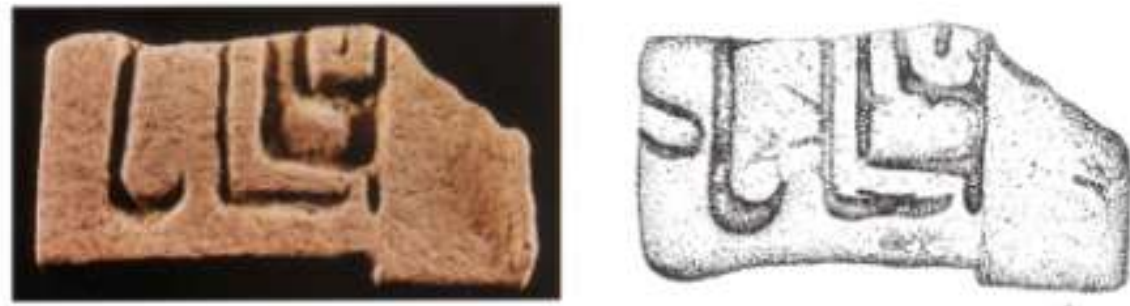

Fuente: El Tajín, en busca de los orígenes de una civilización, pág. 33

Fig. 58. Respaldo de un espejo de piedra pulida labrado en el centro-norte de Veracruz y encontrado en una ofrenda funeraria de Kaminaljuyú, Guatemala.

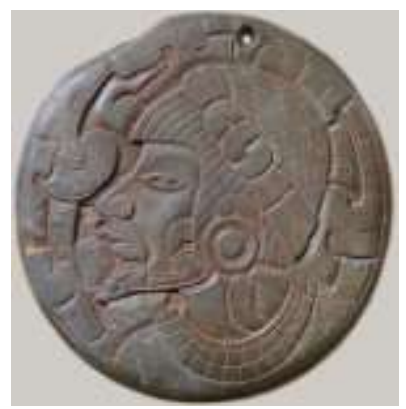

Fuente: www.metmuseum.org

29 Pascual Soto, Arturo, El Tajín, en busca de los orígenes de una civilización, México, D.F., UNAM, Instituto de Investigaciones Estéticas: INAH, 2006, pág. 32 
Para el estudio de la región de El Tajin se realiza una cronología de las diferentes fases de su desarrollo asignándole un nombre a cada etapa, como menciona Pascual Soto. Se anexa la tabla cronológica siguiente:

CRONOLOGIA DE LA REGIÓN DEL EL TAJíN 30

\begin{tabular}{|c|c|c|}
\hline PERIODO & TEMPORALIDAD & FASE \\
\hline Posclásico tardío & $1300-1520$ & Cabezas \\
\hline Posclásico temprano & $1100-1300$ & E1 Cristo \\
\hline Epiclásico & $900-1100$ & Isla B \\
\hline Clásico tardío & $600-900$ & Isla A \\
\hline $\begin{array}{lll}\text { Clásico temprano } & y \\
\text { medio } & & \end{array}$ & $350-600$ & Cacahuatal \\
\hline Protoclásico & 350 d.C. & Tecolutla \\
\hline Formativo tardío & 300 a.C. & Arroyo Grande \\
\hline Formativo medio & $\begin{array}{l}550-300 \\
1000-550\end{array}$ & $\begin{array}{l}\text { Esteros B } \\
\text { Esteros A }\end{array}$ \\
\hline Formativo temprano & $1150-1000$ & Ojite \\
\hline
\end{tabular}

Esta tabla identificará mejor los distintos períodos durante los que se desarrollaron las diferentes fases constructivas de la ciudad.

30 Pascual Soto, Arturo, El Tajín, en busca de los orígenes de una civilización, México, D.F., UNAM, Instituto de Investigaciones Estéticas: INAH, 2006, pág. 22 
Antes de revisar las fases constructivas de El Tajín, cabe mencionar aspectos importantes de su urbanismo, al considerarse como un centro ceremonial con influencias regionales en sus inicios y posteriormente alcanza un gran desarrollo urbanístico durante el Período Clásico tardío distinguiéndose como la más importante ciudad de la Costa del Golfo. La ciudad de El Tajín es edificada en una superficie de 144 hectáreas y cuenta con 168 edificios, que representan sólo el $10 \%$ de la totalidad, que permanece sin explorar. Su traza urbana estuvo condicionada por la naturaleza del terreno, tendiendo a la verticalidad y ensanchándose hacia el norte. Los desniveles naturales de sus laderas fueron aprovechados por sus constructores para marcar distintas áreas arquitectónicas, administrativas y de organización social. Se edifican construcciones de carácter simbólicoreligioso como templos, adoratorios, basamentos piramidales, juegos de pelota así como palacios residenciales de dos pisos con ventanas $\mathrm{y}$ techos colados, algo poco común en la arquitectura prehispánica.

El espacio urbano disponible también fue aprovechado al cien por cien, dando lugar al cerramiento hacia el interior central de la ciudad y diseñando edificios que presentan una doble utilidad:

Al interior del sitio se localizan edificios que cumplen con una doble función de acuerdo a su ubicación. Hay diversos ejemplos: los que forman parte de una plaza y al mismo 
tiempo hacen parte de un juego de pelota, los localizados en el centro haciendo parte de dos plazas, otro ejemplo concreto sería el edificio número 16; la fachada sur hace parte de la plaza del Arroyo y en sentido opuesto, la sur se integra arquitectónicamente al cabezal del juego de pelota 13-14 o a veces formando parte de un complejo mayor. La idea de los constructores es clara: no dejar los complejos aislados, en una concatenación, darle una doble función a las construcciones y la utilización al máximo de los espacios disponibles. Ésta es una particularidad no sólo del Tajín sino de la región. ${ }^{31}$

El Tajín se distingue también por sus numerosas canchas para la práctica ritual del juego de pelota, 17 hasta ahora descubiertas, confirmando así su importancia como centro ceremonial en la Costa del Golfo.

A partir del Proyecto Tajin se lograron hacer estimaciones acerca de su población, que según Brüeggemann es de alrededor de 25,000 a 30,000 habitantes. Las casas habitacionales estaban asentadas en la periferia del centro ceremonial, construidas sobre terrazas artificiales.

31 Jiménez Lara, Pedro, Cuadernos de Trabajo No.15: Arquitectura y poder en El Tajín, México, Instituto de Investigaciones Histórico-Sociales, Universidad Veracruzana, 2002, pág. 11. 


\begin{abstract}
Los espacios domésticos se localizan en complejos de unidades compuestas y se identifican hasta tres estructuras en cada conjunto (Manzanilla, 1986), lográndose una clara diferencias del status de sus moradores a partir de su cercanía con el centro principal y de los materiales de construcción. ${ }^{32}$
\end{abstract}

Se han identificado tres fases o etapas de desarrollo urbanístico, considerando la antigüedad de los edificios, las variaciones de su sistema constructivo y de sus elementos escultóricos-arquitectónicos.

\title{
3.3.1 Fase 1.
}

En esta primera etapa, definida por Brüggemann como fase pre-urbana se levantaron las primeras construcciones en la parte más baja al sur del asentamiento, con un eje simétrico de acuerdo a la tradición clásica mesoamericana y con una desviación de $20^{\circ}$ al noreste. Estos edificios monumentales identificados como 16, 18, 19 y 20 conforman la Plaza del Arroyo o Grupo del Arroyo circundando una amplia y espaciosa plaza.

32 Jiménez Lara, Pedro, Cuadernos de Trabajo No.15: Arquitectura y poder en El Tajín, México, Instituto de Investigaciones Histórico-Sociales, Universidad Veracruzana, 2002, pág. 12. 
Fig. 59. Mapa de El Tajín

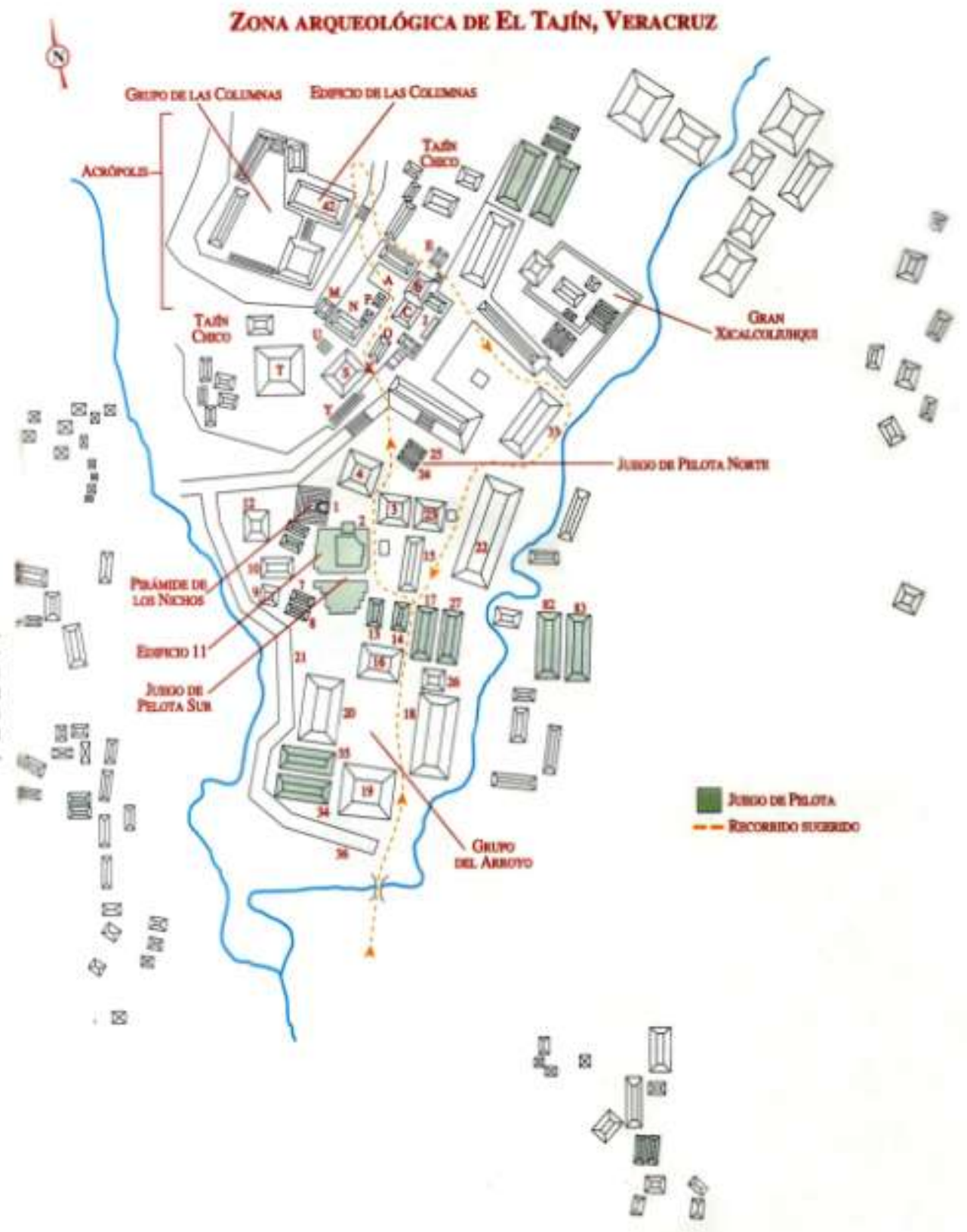

Fuente: Arqueología Mexicana 
La función de estos edificios, según Brüggemann, es ceremonial, ya que, supuestamente, se celebrarian fastuosas actividades religiosas y de culto. Asociados a este conjunto se encuentran algunos juegos de pelota identificados como edificios 34-35, situados en la esquina suroeste y 17-27, esquina noreste; a finales de esta fase se construye otro juego de pelota, edificios 13-14 relacionados con la Plaza, pero fuera del núcleo de la misma.

Es importante señalar que ya desde sus inicios, la arquitectura-escultura de El Tajin presenta sus elementos que la caracterizan, es decir, los nichos y cornisas voladas a la manera teotihuacana talud-tablero, pero en este caso talud, tablero-nicho, cornisa volada. Escultóricamente aparece el concepto simbólico-religioso del "monstruo de la tierra" labrado en las esquinas de los juegos de pelota; su representación es una especie de animal antropomorfo lagartoserpiente de cuyas fauces emerge un rostro humano.

\subsubsection{Fase II.}

Esta se conoce como fase urbana, (Brüggemann) durante la cual se expande la ciudad hacia el norte y cambia su orientación a $45^{\circ}$ noreste. Los edificios son de mayor calidad y tecnología. Se construye la zona conocida como Tajin Chico (edificios de la A a la U), siendo la etapa de mayor apogeo de El Tajín (600-900 d.C. Período Clásico Tardío); es un área residencial de edificios palaciegos para una población de élite, 
gobernantes y clase sacerdotal, la zona de mayor status socialmente hablando. Los edificios están a un nivel más alto que el Grupo del Arroyo, para la cual acondicionaron espacios, rellenándolos para construir terrazas artificiales protegidas con un gran muro de contención formando una barrera arquitectónica que separa una zona de otra; el acceso es a través de escalinatas adecuadas para este fin. En opinión de Brüggemann, esta etapa es la culminación de la planificación y del diseño urbano en el momento de mayor esplendor de El Tajín ${ }^{33}$. El Palacio de las Columnas, la acrópolis de la ciudad, es el edificio más grande e importante, asiento del gobernante supremo 13 Conejo, desde el cual se domina todo el paisaje urbano y de sus alrededores. Es la zona de acceso más restringida.

Además de El Tajín Chico, en el área central e intermedia se construyen los edificios 4, 6, 10, 12, 15 y 23, la plataforma del edificio 5, los juegos de pelota Norte y Sur, 11-11 bis, 7-8, 1314; es notorio en esta zona la concentración de construcciones que se suceden una tras otra y en donde todos los espacios exteriores disponibles se aprovechan. "Es un orden dentro del desorden urbanístico, en el cual no es importante encontrar la recta”, afirmó Brüggemann.

Algunos de estos edificios también tienen doble utilidad.

Los bajorrelieves escultóricos de los juegos de pelota se componen de frisos y franjas a base de volutas y ganchos

12 Solis, Felipe, El Tajín, sitios arqueológicos del estado de Veracruz de la serie Guías Arqueológicas de México Desconocido, México, Edit. México Desconocido, S.A. de C.V. 2003, pág.45 
entrelazados, elementos que identifican el "estilo Tajín".

\title{
3.3.3 Fase III.
}

Es la última fase que va aproximadamente del 900 a 1100 d.C. (Epiclásico); para Brüggemann, la ciudad crece desordenadamente debido a enfrentamientos internos de grupos de poder:

\begin{abstract}
Se erigieron construcciones sin respetar la planeación urbana y el ejemplo más significativo lo constituye la Pirámide de los Nichos, que requiere de un espacio al frente, por lo cual se anexa el edificio 2 a la plataforma (del Edificio 5). ${ }^{34}$
\end{abstract}

Paradójicamente el edificio más emblemático de la ciudad, la Pirámide de los Nichos, se construye al final y es orillado hacia el lado oeste del muro de contención para poder conservar un espacio frontal abierto en su fachada principal. Se crea una plaza con edificios ajenos (edificios 1,2, 3, 4 y 5) y sin contexto urbano 35 .

Otra importante construcción de esta última etapa es La Gran Greca o Gran Xicalcoliuhqui, llamada así por su diseño semejante a una monumental greca escalonada vista desde

34 Solis, Felipe, El Tajín, sitios arqueológicos del estado de Veracruz de la serie Guías Arqueológicas de México Desconocido, México, Edit. México Desconocido, S.A. de C.V. 2003, pág.45

${ }^{35}$ Brüggemann, J., La ciudad de El Tajín, en Arqueología Mexicana Vol.1 Núm.5, México, Edit. Raíces S.A. de C.V. 1993, pág. 29. 
arriba en una sucesión de muros/talud-nichos-cornisas voladas, de 360 metros de longitud, única en su tipo dentro de la arquitectura prehispánica. En el espacio cerrado interior hay dos pequeños juegos de pelota y varias estructuras piramidales. La Gran Xicalcoliuhqui representa la estilización de un caracol cortado o ehecacozcatl (joyel del viento y símbolo de la deidad suprema Ehécatl-Quetzalcoatl) con la forma de una gran greca escalonada. Esta estructura formal se vuelve un recurso arquitectónico-urbanístico y advierte la utilización del mismo como elemento escultórico repetido en los edificios de El Tajín Chico. Además de esto y de su peso simbólico, se cree que es un gran calendario lunar, porque cuenta con 260 nichos a lo largo de su muro perimetral, en asociación directa los 260 dias que tiene el calendario lunar mesoamericano.

Otras construcciones son los edificios $33,34,35,36,37,38$, 39 y 40, así como los juegos de pelota 30-31, 30-31 bis y 8283. Destacan en las técnicas constructivas grandes losas planas coladas, fabricadas con un mortero de cal y arena; así como un arco falso o arco maya, columnas de tambores de piedra con bajorrelieves en donde aparece repetidamente el gobernante 13 Conejo.

En cuanto a la escultura, Piña Chan nos aporta algunas variantes del simbolismo de los frisos:

...en esta fase se continúan los tableros con bajorrelieves y los frisos dentro de un estilo simbólico-realista que se relaciona con el culto a Quetzalcoatl bajo otras 


\begin{abstract}
advocaciones, entre ellas como dios del
"Viento Tempestuoso" que tenía una sola pierna y se le llamaba "Huracán"; así como dios del "Rayo o el Trueno", de donde se derivó El Tajín o “Trueno Viejo”, sin contar con otros aspectos venusinos"36.
\end{abstract}

Todas estas construcciones en su momento estuvieron recubiertas de estuco y completamente policromadas exteriormente así como también los muros interiores tuvieron pintura mural empleando colores como verde, azul maya, azul claro, amarillo, rojo, rosa, naranja.

El abandono de El Tajín, según el arqueólogo e investigador J. Wilkerson se produce entre 1100 y 1200 d.C. (Posclásico Temprano), y aún se desconocen las causas de este acontecimiento. Tuvo una re-ocupación ocasional como necrópolis sagrada, puesto que se encontraron algunos enterramientos en época posterior de El Tajín.

${ }^{36}$ Piña Chan, Román/Castillo Peña, Patricia, Tajín, la ciudad del Dios Huracán, México, Fondo de Cultura Económica, 1999, pág.86 


\section{SEGUNDA PARTE: EL LENGUAJE DEL ARTE DE EL TAJIN.}

En esta segunda parte del presente trabajo se pretenden abordar los objetivos principales que comprenden el análisis del lenguaje del arte de El Tajin a través de los elementos que componen un mensaje visual, sus técnicas de composición, la proporción, morfología y lenguaje formal empleado en el diseño de su arquitectura-escultura para lo cual se revisará el corpus arquitectónico-escultórico más sobresaliente que marca la pauta del impulso creativo dentro del desarrollo históricoartístico de la gran urbe prehispánica. Para entender esta propuesta, se hará mención breve de los conceptos básicos sobre el lenguaje visual, la percepción de la imagen, la Gestalt, para ser aplicados en la arquitectura-escultura de El Tajín. 


\section{CONCEPTO DEL LENGUAJE VISUAL}

Ver es más que simplemente abrir los ojos: es descubrir el mundo que nos rodea. La vista no es sólo un sentido fisiológico, si bien este aspecto es el soporte material e imprescindible de la visión: es una entrada de información primordial para la psique humana, y la que preside en mayor medida la relación del hombre con su entorno. Es por ello que cuando hablamos de agudizar y perfeccionar nuestra capacidad de ver no se refiere a brindar mayor alcance $o$ detalle a las pupilas, sino a aumentar el potencial para comprender los mensajes visuales que llegan a la mente.

Los datos que la mente registra a través de la vista se presentan en tres niveles distintos ${ }^{37}$ :

1. Input visual: una multitud de sistemas de símbolos, de mayor o menor complejidad;

2. Material representacional: el que reconocemos en el entorno y es posible representar; está gobernado por la experiencia directa que traspasa los límites de la percepción;

3. Infraestructura abstracta: forma de todo lo que vemos; es la composición elemental abstracta y, por lo tanto, el mensaje visual puro.

${ }^{37}$ Dondis, Donis, La sintaxis de la imagen. Barcelona, Editorial Gustavo Gili, 2007, p. 18 
Estos niveles actúan simultáneamente. Decodificar cada uno de ellos para actualizar los mensajes que llegan desde el exterior requiere tomar conciencia acerca de la necesidad de perfeccionar habilidades a este respecto. Donis Dondis señala:

El modo visual constituye todo un cuerpo de datos que, como el lenguaje, pueden utilizarse para componer y comprender mensajes situados a niveles muy distintos de utilidad, desde la puramente funcional a las elevadas regiones de la expresión artística. Es un cuerpo de datos compuesto de partes constituyentes, de un grupo de unidades determinadas por otras unidades, cuya significancia en conjunto es una función de la significancia de las partes. ¿Cómo definir las unidades y el conjunto? Mediante pruebas, definiciones, ejercicios, observaciones y eventualmente líneas maestras que permitan establecer relaciones entre todos los niveles de la expresión visual, entre todas las categorías de las artes visuales y su "significado"38.

La problemática del lenguaje visual debe reconocer como punto de partida una verdad cierta: este lenguaje no tiene hasta ahora leyes obvias y unificadas que lo sustenten, sino un conjunto de apreciaciones comunes interpretadas a su

${ }^{38}$ Dondis, D. op. cit, p. 20. 
manera por cada productor de mensajes visuales. En la lengua, la sintaxis es la manera en que, de acuerdo con determinadas reglas comunes, aceptadas y conocidas por todos los hablantes -la gramática y la ortografia- se dispone el material significativo (las palabras), de modo que el mensaje que se transmite sea correctamente entendido por los receptores. Al hacer referencia al lenguaje visual, no es posible que la comunicación que instaura se rija y comporte como en el modelo del lenguaje hablado, si bien es factible desarrollar tanto la habilidad para la composición y la lectura de las producciones plásticas, gráficas y arquitectónicas, como establecer con un buen grado de certeza sobre qué variable del esquema comunicativo incide en cada elemento.

Además, en los mensajes visuales el significado no se limita sólo a ser la suma de partes incluidas en la obra o el diseño, sino que la incidencia de los mecanismos de la percepción del organismo humano es determinante. La luz es la condición sine qua non de la que depende el acto de ver. Todos los demás elementos visuales se patentizan mediante ella, y su carácter final será determinado por el tono, esto es, por la luminosidad. Por ello, la comunicación visual, a fin de lograr la univocidad o monosemia -el sentido único e invariable- se ve obligada siempre a abordar una sintesis o a reconocer su complejidad (en el caso, por ejemplo, de las obras de arte) y dejar un sentido abierto y en gran medida indeterminado, como efecto tanto de su riqueza semántica (lo que es deseable y la hace una verdadera obra de arte) como de la carencia de educación 
visual del espectador, carencia que lo inhabilita para abordar la complejidad total del mensaje (lo que no es deseable, claro está) ${ }^{39}$.

Es importante destacar que en el presente trabajo considera a la arquitectura-escultura de El Tajin como formas visuales, que se analizarán bajo el modelo esbozado en el apartado 4.4 del presente tema.

\subsection{El lenguaje visual y sus componentes básicos.}

Así como el aprendizaje de la lengua requiere, primeramente, identificar sus unidades primarias (las palabras y sus funciones: sustantivo, adjetivo, verbo, etc.) para luego entender y aplicar las normas que regulan su uso, introducirse en el estudio del lenguaje visual requiere, como paso inicial, conocer sus componentes básicos, a fin de comprender, más adelante, la complejidad que gobierna sus combinaciones.

Estos elementos visuales básicos son ${ }^{40}$ :

El punto: unidad simple, mínima e irreductible. Indica una posición en el espacio. Al conectarse dos o más puntos son capaces de dirigir la mirada, o de sugerir un eje perpendicular a la línea por ellos insinuada.

\footnotetext{
${ }^{39}$ Sería el caso, haciendo una comparación con el idioma de un hablante cuyo léxico fuese muy limitado, y que no estuviera al corriente de las reglas gramaticales y de la sintaxis de esa lengua.

${ }^{40}$ Para las siguientes descripciones se han utilizado como fuentes: Dondis, D., op. cit., pp. 54-67; Ching, F., Arquitectura: forma, espacio y orden. México, Editorial Gustavo Gili, 1995, pp. 19-51.
} 
La línea: cadena de puntos. También es entendida como un punto en movimiento o como el registro del movimiento de un punto, dada que siempre transmite esa sensación al ojo. Sus propiedades son la longitud, la dirección y la posición. En arte, es el elemento esencial del dibujo. En toda construcción visual, la línea es útil para agrupar o contener otros elementos visuales y definir las formas y superficies de los planos. Su orientación se asocia con estados de equilibrio y regularidad, o la ausencia de ellos.

El plano: se produce por la extensión de una línea. Sus propiedades son: longitud $\mathrm{y}$ anchura, forma, superficie, orientación y posición, y ellas determinarán las características visuales de las formas que definen y las cualidades del espacio que encierran.

El volumen: es el resultado de la extensión de un plano. Sus características son: longitud, anchura y profundidad, forma y espacio, superficie, orientación y posición. La forma es la particularidad básica para identificar un volumen: la definen los contornos e interrelaciones de los planos que lo delimitan. Puede ser sólido (masa que ocupa el lugar de un hueco) o vacío (espacio contenido por planos).

Las propiedades visuales de la forma son la posición (lugar que ocupa en un espacio), la orientación (posición respecto de los puntos cardinales o del observador), y la inercia visual 
(depende de su geometría y de la orientación que posea en un momento y lugar dado).

El contorno: cuando la línea define un contorno, genera las tres figuras básicas: el cuadrado, el círculo y el triángulo, que tienen, cada uno, rasgos particulares y significados simbólicos propios.

Dirección: hay tres direcciones básicas, expresadas por las figuras elementales: horizontal y vertical (el cuadrado), diagonal (el triángulo) y la curva (el círculo). La primera se asocia a la idea de equilibrio y es, como se ha señalado, referencia primaria para el hombre; la segunda se relaciona al concepto de estabilidad, dado que es la fuerza direccional más fluctuante; la tercera tiene connotaciones de encuadramiento, repetición y calor.

Tono: son las variaciones de la luz, su mayor o menor intensidad; gracias a él distinguimos y separamos la información visual del entorno que nos rodea y percibimos el volumen y la perspectiva.

Color. el elemento más cercano a las emociones. Está cargado de información y de asignación simbólica, y es uno de los elementos, por tanto, predilecto de los comunicadores visuales por las posibilidades que ofrece. Hay tres matices primarios: el amarillo (más cercano a la luz y el calor), el rojo (el más emocional y activo) y el azul (pasivo y suave). Cuando se asocian, cada mezcla engendra nuevos significados. 
Wucius Wong realiza una interesante clasificación de estos elementos en cuatro grupos ${ }^{41}$ :

Elementos conceptuales: no son visibles. De hecho no existen físicamente, sino que aparentan estar presentes.

- Punto

- Línea

- Plano

- Volumen

Elementos visuales: cuando los elementos conceptuales se hacen visibles, adquieren forma, medida, color y textura. Son los elementos que realmente vemos.

- Forma

- Medida

- Color

- Textura

Elementos de relación: son lo que determinan e lugar y al interrelación de los componentes de un diseño.

- Dirección

- Posición

- Espacio

${ }^{41}$ Wong, Wucius, Fundamentos del diseño. Barcelona, Editorial Gustavo Gili, 2007, pp. 41-46. 
- Gravedad

Elementos prácticos: en ellos se apuntala el contenido y el alcance de un diseño:

- Representación

- Significado

- Función

Este autor agrega, como elementos indispensables de una composición visual, el marco de referencia (los límites espaciales en los que se ubican todos los elementos citados anteriormente) y el plano de la imagen (superficie plana del papel u otro material en el que el diseño ha sido creado).

\subsection{La percepción de la imagen y la Gestalt.}

Interesa a los fines de este trabajo el enfoque de la psicología Gestalt, dado que esta escuela ha dedicado muchos de sus esfuerzos a investigar los procesos de la percepción. Una de sus ideas básicas es que los elementos físicos y psicológicos de la percepción son relativos, nunca absolutos, y se comportan primordialmente como estímulos que generan, en gran medida, una respuesta automática, a diferencia de la lengua, cuyo proceso de abstracción remite a operaciones inteligibles que se desarrollan dentro de un marco estable, casi fijo; el contexto de la percepción visual es dinámico y sujeto a transformaciones permanentes, ya que la reacción a un 
estímulo es inevitable y modifica el marco en que se desarrolla la comunicación visual.

A grandes rasgos se puede afirmar que la Gestalt tiene como base teórica la hipótesis de que para comprender cualquier sistema se debe aceptar que:

- dicho sistema es un todo compuesto por partes interdependientes;

- que cada parte puede aislarse para su estudio particular;

- $\quad$ si se modifica cualquier componente del sistema, se modificada la totalidad;

Es por esto que la teoría Gestalt es una herramienta muy útil para abordar cualquier obra visual, dado que las obras fueron y son concebidas como una totalidad, un sistema que posee su equilibrio y sus leyes internas de funcionamiento. Las relaciones elementales que identifica esta escuela en la percepción visual son:

Equilibrio: el hombre percibe, fruto de su evolución biológica, en posición vertical, y se esfuerza siempre por mantenerse en esa posición ya que le sirve de referencia obligada en su relación con el mundo que lo rodea. Toda percepción visual busca ese equilibrio, que se compone en la mente de un eje vertical y un referente secundario horizontal. 
Tensión: la mente busca ordenar las percepciones que se le ofrecen a través de la vista de acuerdo con este eje cartesiano imaginario. En la medida que un estímulo visual se amolde o entre en conflicto con la regularidad que establece ese eje, tendrá menor o mayor tensión.

Nivelación y aguzamiento: a la armonía se opone lo discordante, y en ese juego de opuestos intervienen los procesos de nivelar lo percibido (intentar ajustarlo a la lógica del eje) o de aguzarlo, esto es, reconocer el grado de excentricidad que tiene un elemento respecto del eje de equilibrio.

Así, la Gestalt señala que con las percepciones automáticas se identifica clara y rápidamente un equilibro o la ausencia de él, de modo que se reconocen sin obstáculos las condiciones visuales abstractas. Pero hay una tercera forma de la composición visual que ni está nivelada ni aguzada, y que le plantea al ojo dificultades a la hora de analizar el estado de equilibrio de los componentes. Esta es una situación de ambigüedad:

La ambigüedad visual, como la ambigüedad verbal, no sólo oscurece la intención compositiva, sino también el significado. El proceso de equilibrado natural quedaría frenado, confundido $\mathrm{y}$, lo que es más importante, irresuelto por culpa de la fraseología espacial $\sin$ 
significado. La ley Gestalt de la simplicidad perceptiva es transgredida en gran parte por este tipo de estados poco claros de diferenciación en toda composición visual. La ambigüedad es totalmente indeseable desde el punto de vista de una sintaxis visual correcta. La vista es el sentido que menos energía gasta. Experimenta y reconoce el equilibro, evidente y sutil, y las relaciones de interacción entre los diversos datos visuales. Seria contraproducente frustrar y confundir esta función única. Idealmente, las formas visuales no deberían ser nunca deliberadamente oscuras; deberian armonizar o contrastar, atraer o repeler, relacionar o chocar ${ }^{42}$.

Para la Gestalt hay además una serie de fenómenos secundarios que incrementan la tensión visual:

- Preferencia por el ángulo inferior izquierdo: es un fenómeno que no posee una explicación cierta; quizás es producto de la evolución o de los hábitos de lectura de izquierda a derecha en determinadas

${ }^{42}$ Dondis, D. op. cit., p. 41. 
culturas. Pero es determinante a la hora de maximizar la tensión visual.

- Peso: los elementos visuales ubicados en zonas de tensión tienen más peso en la composición, dado que atraen más fuertemente la atención de la vista, $\mathrm{y}$ por ende este fenómeno gravita en el equilibrio del conjunto.

Atracción y agrupamiento: se refiere a la interacción que establecen dos o más elementos de una composición. El ojo busca agrupar siempre un conjunto de elementos similares, y hasta imagina las relaciones que puede haber entre ellos en caso de que no fueran voluntarias. Para el ojo los opuestos se repelen y los semejantes se atraen.

Positivo y negativo: estos términos no tienen relación con lo claro y lo oscuro, ni connotaciones valorativas, sino que refieren al elemento que atrae la mirada y es por ello más activo en una composición, y al o los elementos secundarios que poseen un rol pasivo.

\subsection{Modelo de análisis formal para el lenguaje visual de la cultura de El Tajin}

Carlos Montes Serrano define el análisis como "cualquier labor encaminada a obtener un conocimiento cierto y exhaustivo de una realidad determinada; conocimiento que adquirimos 
mediante cierta operación intelectual que permite estudiar $y$ captar las propiedades esenciales o constitutivas de un objeto; conocimiento que no podemos alcanzar mediante la simple percepción del objeto o de la realidad." 43

Señala así las operaciones intelectuales que suponen un análisis, y la diferencia en la calidad y el nivel de la información que se consigue con el mismo respecto de la simple visión.

El análisis como operación intelectual remite al estudio de un objeto a través del desmenuzamiento concienzudo de las partes que lo componen. Por ello, estará muy ligado en su primera etapa a la observación meticulosa y a la descripción.

En lo correspondiente al análisis de las formas estéticas, el autor hace una adecuada clasificación de las distintas tipologías analíticas y sus supuestos teóricos. Básicamente reconoce dos caminos posibles:

- descomponer la forma en los elementos relacionados que la constituyen: la finalidad es estudiar los elementos compositivos de manera independiente, para luego indagar en el modo en que estos elementos se interrelacionan tanto entre ellos como con la totalidad de la unidad formal. Así, dos operaciones son las principales para este tipo de análisis: la descomposición en partes y, en un segundo momento, la síntesis.

43 Montes Serrano, Carlos, Representación y análisis formal, Secretariado de Publicaciones Universidad de Valladolid, Valladolid,1992, pp. 157-160. 
- indagar en los principios o leyes que han regido su proceso generativo: aquí se busca conocer, a través de un acercamiento ordenado, metódico y razonado, la forma a partir de sus causas y principios generadores, para intentar explicar la dinámica complejidad de factores que la ha generado.

Al tomar uno de estos dos caminos, y al ser guiados por un concepto de forma que sirva para definir las áreas de interés de la investigación en particular, se han de encontrar con distintas opciones.

Si la forma es entendida como configuración, los análisis formales pueden ser:

- descriptivos: los puramente analíticos. Como su nombre lo indica, el rumbo de las indagaciones se dirige hacia la enumeración de los elementos constituyentes de la forma, a fin de descubrir luego las relaciones que los unen con el todo de la composición. Esta clase de análisis deberá detenerse especialmente sobre la geometría y las dimensiones de la forma y sus elementos, y las relaciones de orden (simetria, proporción, posición, ritmo y armonia) que se ven siempre influidas por aspectos perceptivos de la forma (color, claroscuro, textura) 
- fenomenológicos: centrarán su atención en la forma como fenómeno. Esto implica indagar en los modos de la percepción y la comprensión de las formas, y cómo se configuran los diversos elementos en la conciencia del espectador.

Si se entiende el concepto de forma como la resultante de un proceso de configuración formal, entonces corresponde decantarse por el análisis procesativo: sobre la base de un análisis descriptivo, se acentúa la interpretación de las intenciones formantes que presidieron la creación de las estructuras de las obras estéticas consideradas. Montes Serrano distingue dos clases de análisis procesativos: los que intentan descubrir la dinámica del proceso de formalización, y los que se concentran en la consideración genética de la forma. Además, si lo relevante en un análisis es reconocer los grupos formales a los cuales responde una obra, se verá en la necesidad de abordar los análisis estilisticos o tipológicos, en los cuales los factores históricos y culturales adquieren el mayor protagonismo.

Ciertamente, al elegir un modo de análisis se procede a observar el objeto (en este caso, la obra artística) desde una perspectiva determinada; es por ello que siempre es menester combinar las diferentes visiones que brindan los diferentes modos de acercarse a la obra para obtener así una visión más rica y completa. 
Esta clasificación general, propuesta por Montes Serrano, es útil para ser introducidos a la manera específica de tratar con las obras que ha legado la cultura de El Tajín. Se ha visto la importancia de trazar un recorrido metodológico que se ciña a los requerimientos individuales de cada obra, pero teniendo en mente siempre los aspectos analíticos que guian esta investigación. Por ello se hace necesario esbozar un modelo de análisis para el lenguaje visual de la cultura de El Tajín.

Existe con un precedente muy valioso que se encuadra además con las propuestas epistemológicas que se han trazado en las páginas precedentes: el trabajo de José Francisco Villaseñor Bello acerca del lenguaje visual de las pinturas murales de Bonampak ${ }^{44}$. Este autor señala como distintivo de la civilización mesoamericana el sitio predominante que ocuparon las imágenes en las distintas sociedades que poblaron la región a lo largo del tiempo, y cómo, a partir del estudio de sus respectivos lenguajes visuales, se ha logrado penetrar en muchas de las claves de su complejo pensamiento.

Villaseñor Bello se ve en la necesidad de establecer un modelo de análisis novedoso, ya que la estética mesoamericana no puede comprenderse plenamente a partir de los cánones occidentales contemporáneos; es por ello que en su trabajo de investigación, su principal objetivo ha sido rescatar, en la

\footnotetext{
${ }^{44}$ Villaseñor Bello, José F., Concepto, ojo y trazo: una aproximación al lenguaje visual de Bonampak En: La pintura mural prehispánica en México Área Maya Bonampak Tomo II, UNAM Instituto de Investigaciones Estéticas, México, 1998, pp. 81-84.
} 
medida de lo posible, el punto de vista prehispánico en la manera de configurar los elementos visuales, para asî lograr un mejor acercamiento a la lectura de sus discursos plásticos. Tomando como punto de partida el modelo de análisis de la Escuela de Viena -escuela que busca relacionar la historia cultural y la historia de las formas-, y deteniéndose particularmente en las propuestas de Hans Sedlmayr y sus discipulos del Instituto Warburg -basadas sobre los aportes del formalismo, la Gestalt y la historia de la cultura-, Villaseñor Bello traza dos supuestos fundacionales para su propio trabajo:

- la obra de arte no se encuentra nunca aislada;

- el valor de una obra se ha de comprender teniendo en cuenta su significación religiosa, su fundamento intelectual y las condiciones culturales de la sociedad en que vio la luz.

Así, los inevitables análisis descriptivos abren la puerta, en una segunda instancia de estudio, a la interpretación hermenéutica de la obra, interpretación que estará dirigida hacia el sentido que esa forma tenía en su contexto original de producción. Los aportes que hacia la mitad del siglo XX realiza el Estructuralismo, sobre la base del modelo de la Lingüística y la Semántica, ayudan a encontrar el necesario lazo entre la forma (el significante) y su sentido (el significado). 
Por otra parte, las teorías de la Gestalt acerca de la percepción sirven como apoyo evidente al modelo de análisis estructural. Esta conjunción de ideas lleva a concluir a este investigador que "lo importante en la interpretación es la comprensión visual de las formas representativas, es decir: captar y analizar las cualidades visuales, las formas y las figuras." 45

El modelo de análisis que se perfila a partir de dichos postulados (los estructurales-lingüísticos y los gestalticos) presenta diferentes momentos y niveles de aproximación a la obra:

- Un primer momento en que se capta la cualidad visual que se halla en cada detalle y en el conjunto total;

- Un segundo momento en el que se propone identificar la figuración y el orden que cada una de las partes tiene en el conjunto ${ }^{46}$.

La ordenación de los elementos se configura tanto en el plano como en el espacio, y es en ese orden que se desarrollan los temas figurativos (formas y figuras que se aprecian de modo directo).

Con la aplicación de este modelo de análisis lo que se busca es reconocer la existencia de un "pensamiento visual", establecido y aceptado tanto por los productores de mensajes (los artistas)

\footnotetext{
${ }^{45}$ Villaseñor Bello, J. F., op. cit., p. 83.

${ }^{46}$ Villaseñor Bello, J. F., op. cit., p. 83.
} 
como por los receptores (espectadores de las obras) a nivel de norma convencional. 


\section{ELEMENTOS FORMALES DE LA ARQUITECTURA- ESCULTURA DE EL TAJÍN.}

Partiendo de los postulados estructuralistas, los cuales consideran, como principio, la descomposición de la forma artística en las diferentes unidades formales que la constituyen y luego indagar en el modo en que estos elementos se interrelacionan entre sí para reunir la totalidad de la unidad formal, se describirán, primeramente, los elementos formales destacados e individuales que conforman la unidad compositiva de los edificios arquitectónicos-escultóricos de El Tajín y, en general de la arquitectura de las antiguas ciudades prehispánicas.

Se hace referencia, específicamente, al talud, tablero, nicho, greca escalonada, etc., que se muestran claros en las estructuras arquitectónicas y cambiantes en escalas, proporciones, geometría, composición formal, según el edificio y su funcionalidad propia. Han sido objeto de estudio multidisciplinar desde el descubrimiento del sitio por parte de García Payón -conservándolos y restaurándolos-, con Marquina, -estudiando su construcción arquitectónica-, y Joan Sarro desde el punto de vista iconográfico.

En otro punto, resalta su importancia plástica porque son estos elementos, en mayor o menor medida, según el caso, los que le dan identidad a su arquitectura; constituyen en sí mismos la base estructural y unidad visual mínima que se 
desdobla, multiplica, ordena, y construye las formas arquitectónicas-escultóricas.

Sirven también a los estudiosos dentro del campo de la semiologia, iconografia e iconología para una interpretación hermenéutica de la obra por su alto contenido simbólico, que es su razón de ser primaria antes que su funcionalidad plástica; sin embargo, no existe oposición sino que conforman la unidad visual que materializa lo que se considera sutil, intangible, inmaterial, la esencia espiritual de su cosmovisión del mundo y del universo que los rodea plasmado en un lenguaje de las formas, proporciones, escalas, simetrias, en sintesis, un lenguaje visual.

\subsection{Talud-tablero/nicho-cornisa volada y sus variaciones formales.}

Se distingue la arquitectura mesoamericana por el empleo generalizado del sistema constructivo talud-tablero en sus edificaciones piramidales, templos, palacios, adoratorios, etc. El talud es el tronco o base del que arranca cualquier basamento; es un plano inclinado, visto de perfil o de frente, con forma trapezoidal en su volumen. Sobre el talud parte el tablero, cuya forma geométrica es un prisma cuadrangular; talud/tablero van unidos conformando el binomio constructivo representado en múltiples variables de escala, proporción, ritmo, etc., que van articulando en una concatenación rítmica el volumen edilicio mesoamericano. 
Fig. 60. Pirámide teotihuacana/Corte de un tablero teotihuacano típico
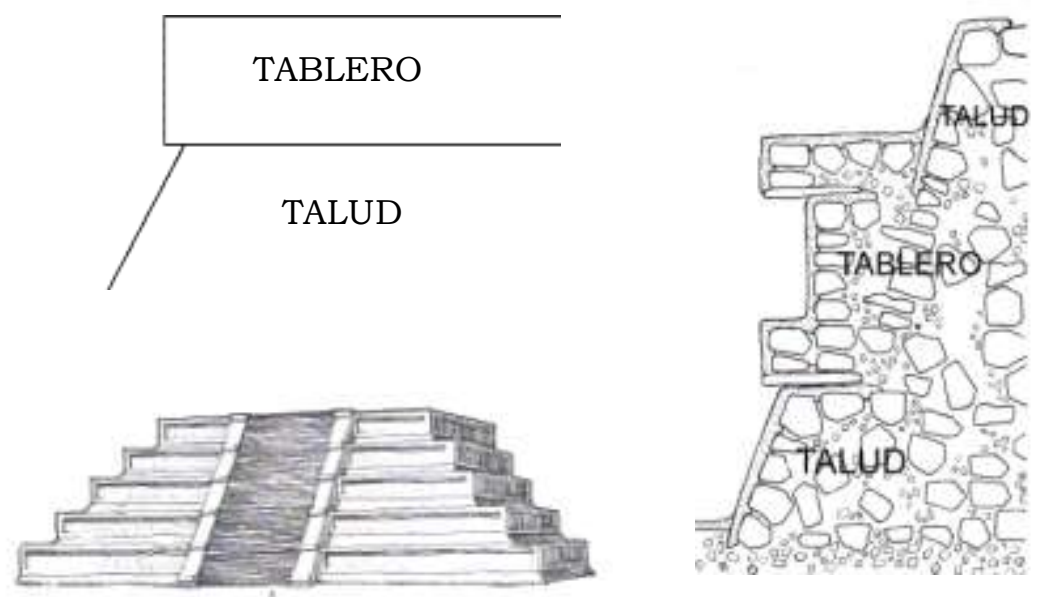

Fuente: Arte Prehispánico en Mesoamérica, P. Gendrop

Algunos ejemplos del uso del talud-tablero en la arquitectura mesoamericana (ejemplos tomados de Arte Prehispánico en Mesoamérica, Paul Gendrop):

Fig. 61. Xochicalco..

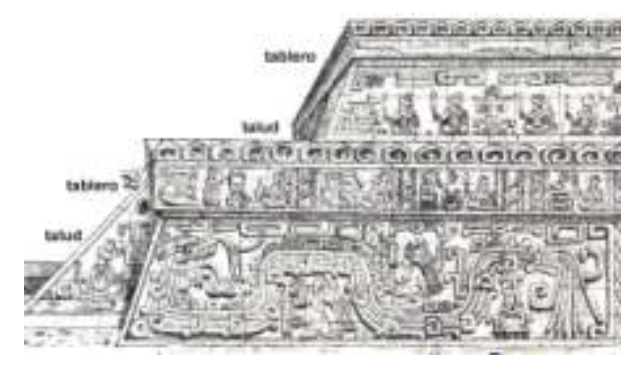

Fig. 62. Cholula, Puebla.

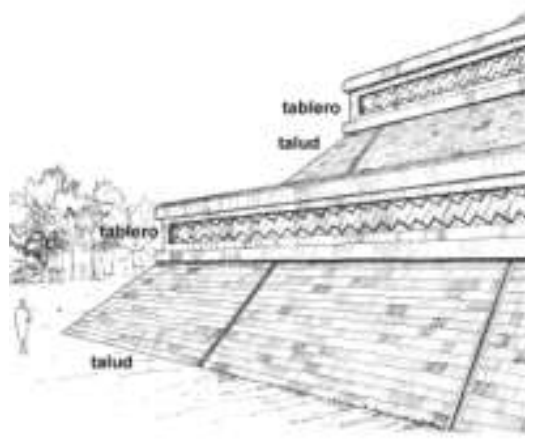

Fuente: Arte Prehispánico en Mesoamérica, P. Gendrop 
Fig. 63. Tajín, Veracruz.

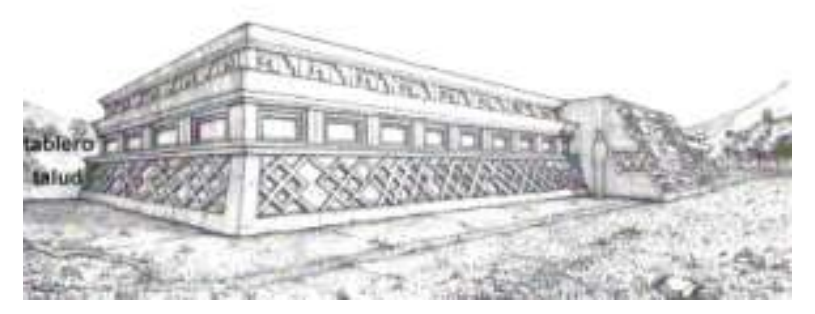

Fuente: Arte Prehispánico en Mesoamérica, P. Gendrop

Los arquitectos e ingenieros de El Tajín le imprimieron el sello particular a este sistema compositivo de origen teotihuacano, introduciendo un elemento novedoso no visto antes en otras ciudades de Mesoamérica: el nicho. El nombre deriva de su forma característica: es un elemento modular de forma cuadrada o rectangular cuyo volumen cúbico deja un espacio negativo u oquedad interior.

En los edificios de El Tajín, el nicho ocupa el lugar del tablero en el esquema compositivo teotihuacano y va unido a una cornisa superior, que se eleva gradualmente creciendo hacia arriba y hacia afuera del tablero-nicho, de tal forma que parece como si quedara en el aire, sin apoyo alguno; de ahí su designación como cornisa-volada. Su volumen es un trapecio. 
Fig. 64. Fotografía de un nicho de la Pirámide de los Nichos derecha/ dibujo lineal del nicho izquierda.
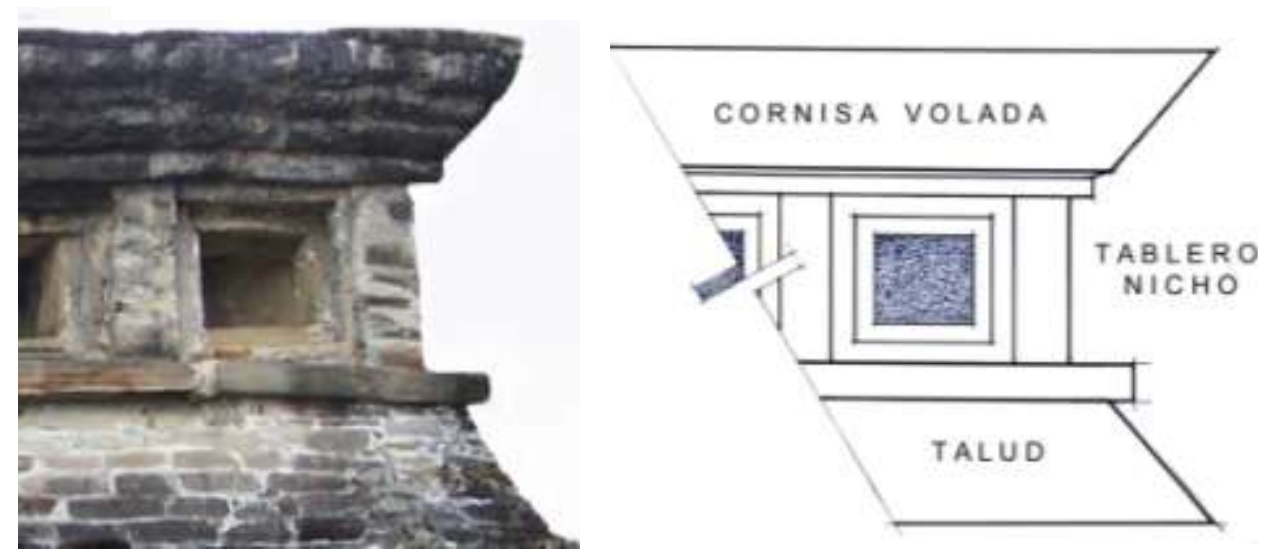

Fuente: L. Valle

Fig. 65. Forma tridimensional de nicho.

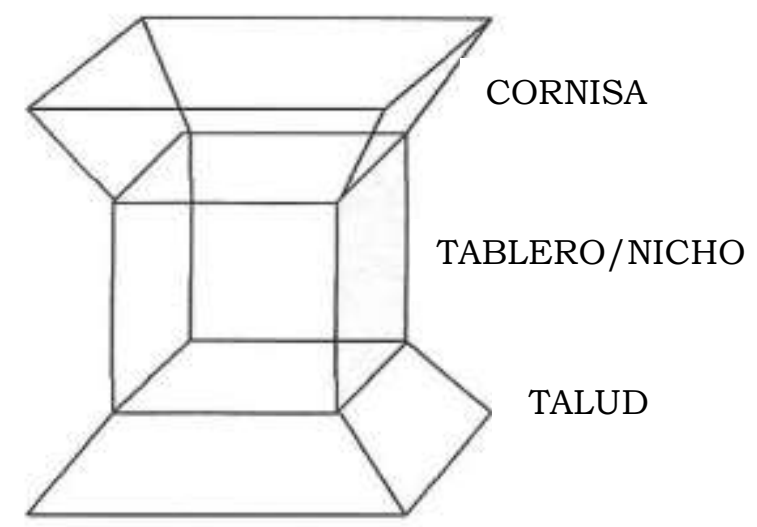

Fuente: L. Valle 
Fig. 66. Nichos en perspectiva. Derecha nicho policromado Los nichos (al igual que los edificios) estuvieron completamente policromados; la parte interior era de color rojo oscuro y el marco azul, de acuerdo a los estudios y restos de color que aún pueden observarse en algunos edificios.
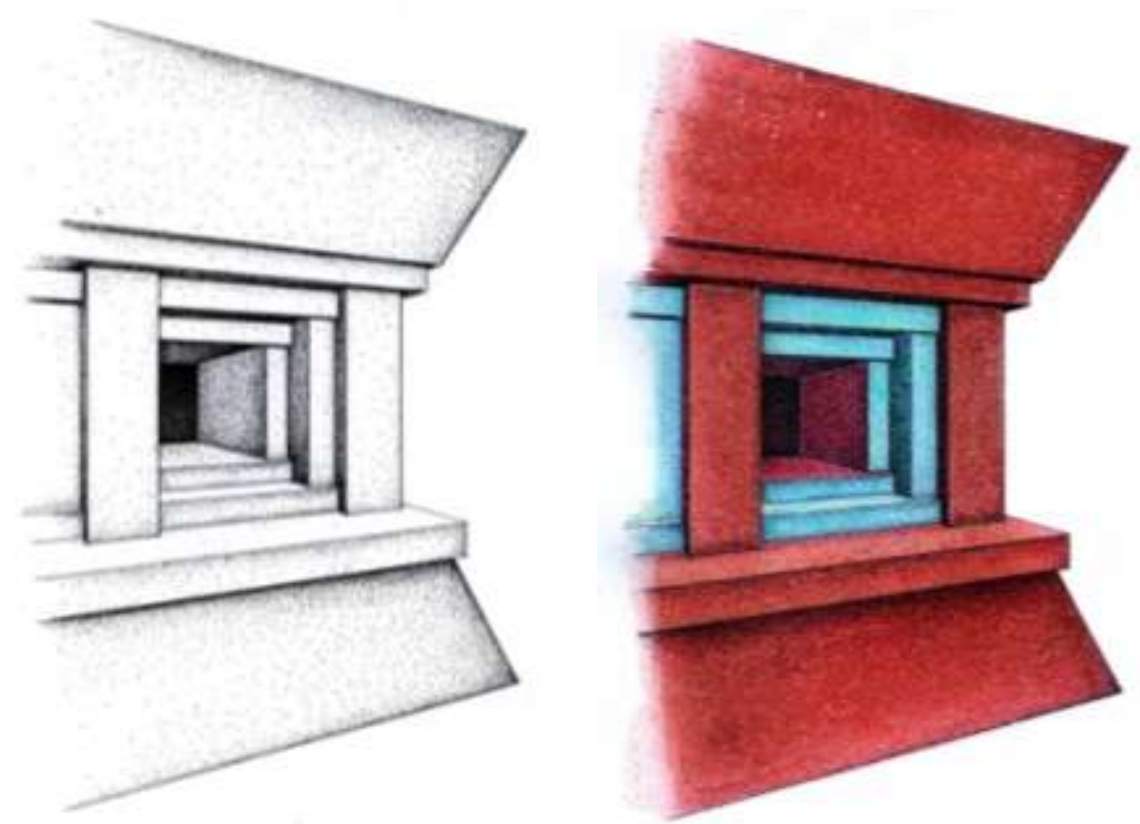

Fuente: L. Valle 
Escalas y formatos. Tanto el talud, tablero/nicho y la cornisa volada se presentan de diversos formatos y proporciones. Por ejemplo, en el caso del nicho, el formato de la abertura se presenta desde $55 \times 52 \mathrm{~cm}$ hasta $70 \times 61 \mathrm{~cm}$ creciendo o decreciendo su talud y cornisa adoptando interesantes variantes compositivas que nunca se repiten en los edificios. $\mathrm{Su}$ complejidad es mayor conforme se va desarrollando la ciudad durante sus fases urbanas; así tenemos que los edificios más elaborados pertenecen a la etapa de mayor auge (800 a 1100 d.C.)

Fig. 67. Algunas variaciones de talud, tablero/nicho, cornisa volada presentes en El Tajín.
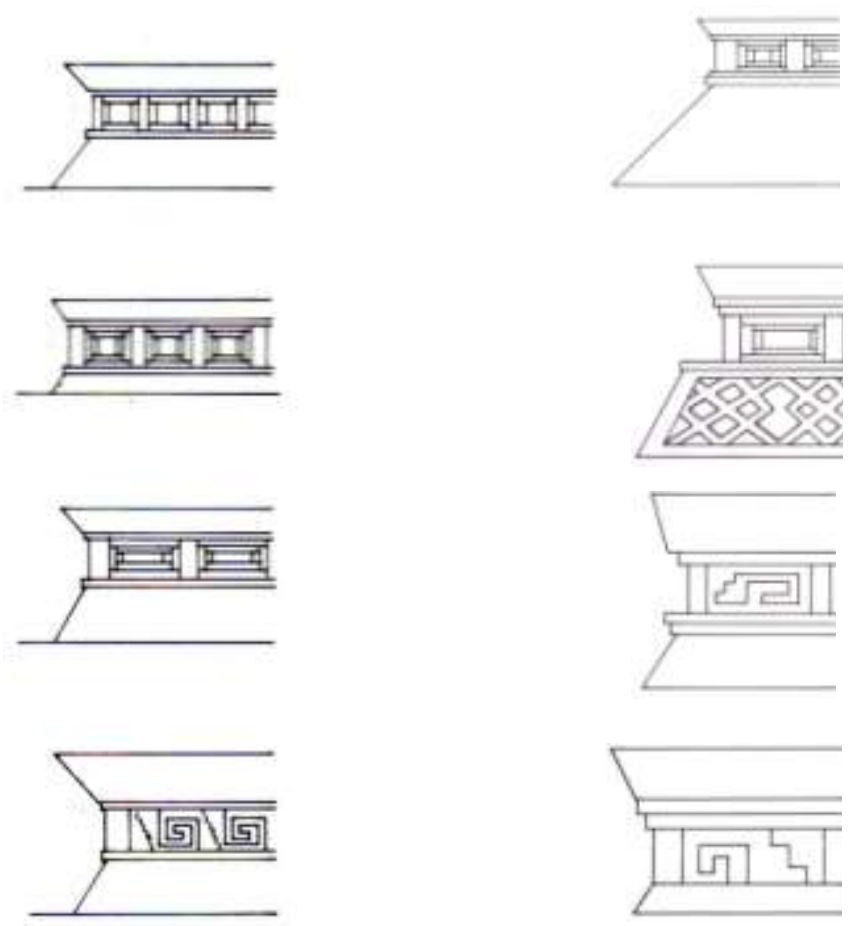

Fuente: Arquitectura Precolombina P. Gendrop,

Fuente: L. Valle 
Fig. 68. Nichos con mayor elaboración y profundidad visual lograda debido a varias sucesiones de paredes interiores en su recubrimiento. Se perciben como nichos dentro de otros nichos. Edificio D Tajín Chico.

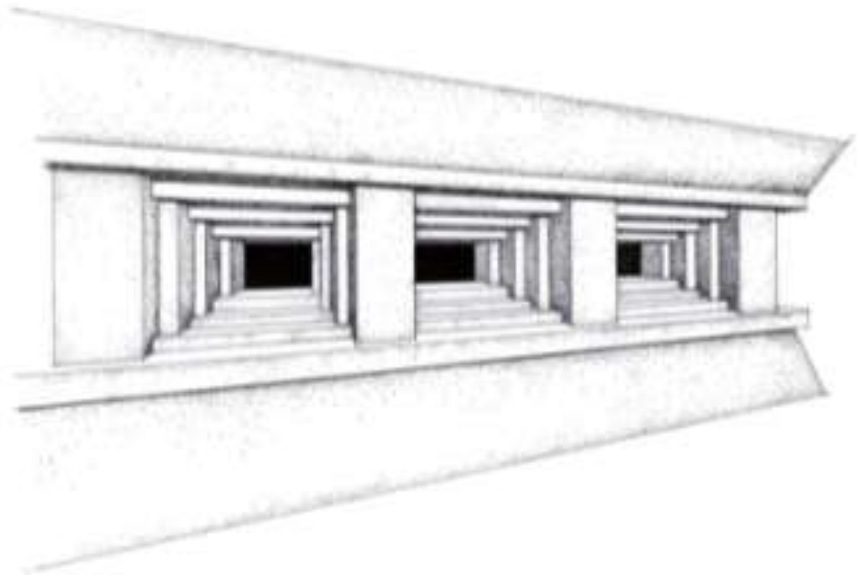

Fuente: L. Valle

Es importante distinguir dentro de la clasificación de elementos formales estructurales, semi-estructurales y no estructurales. El sistema talud, tablero/nicho, cornisa volada son elementos formales estructurales, hablando en términos constructivos porque además de tener una función plástica/artística, son la base constructiva de la estructura arquitectónica. El ejemplo más característico es la Pirámide de los Nichos que está constituida por 365 nichos apilados, tanto horizontal como verticalmente, sobre 7 basamentos que van ascendiendo de mayor a menor proporción, hasta formar la gran pirámide.

Para comprender la construcción del nicho se hace referencia a la aportación que sobre el tema hiciera el arquitecto Ignacio Marquina al explicar el sistema constructivo de los nichos, que es de la siguiente forma: 
Sobre un muro en talud, revestido de piedra, se levanta un paramento vertical, también revestido de piedra, que constituye el fondo del nicho; pequeños apoyos de piedras superpuestas van formando resaltes hasta llegar a las dimensiones del claro que forma el mismo nicho; sostienen enormes losas que aparecen como labradas, pero que realmente presentan este aspecto por haber sido obtenidas de una formación sedimentaria en un lugar cercano. Otras lajas, colocadas sobre la anterior, en un número de seis o siete, ligeramente salientes una sobre otra, forman el esqueleto de la cornisa, cuyo aspecto definitivo de un plano inclinado, se obtiene por medio de un grueso aplanado de estuco.

Este sistema de construcción ha sido causa de numerosos derrumbes, pues al romperse algunas de las losas, ceden los apoyos de la del piso siguiente, rompiéndose también la losa que sostiene, ocasionando la destrucción del edificio, por lo que ha sido necesario hacer grandes trabajos de restauración, con el objeto de asegurar su estabilidad. 47

\footnotetext{
${ }^{47}$ Marquina, Ignacio, Arquitectura Prehispánica, México, INAH, 1964, p. 430
} 
Fig. 69. Isométrico y vista lateral de un talud-nicho-cornisa volada
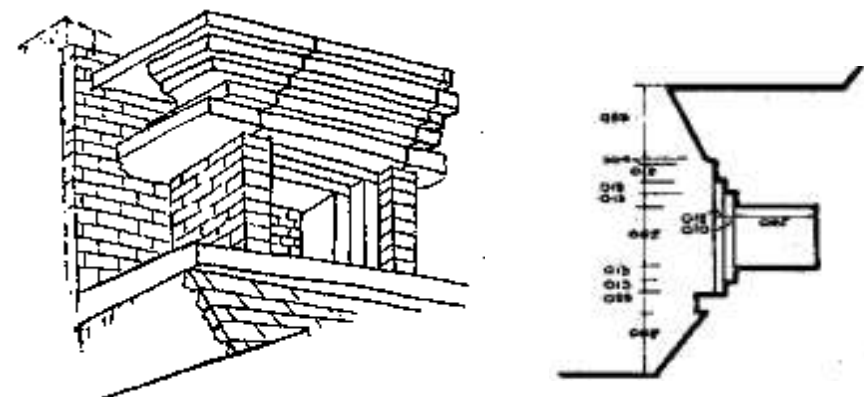

Fuente: Arquitectura Prehispánica, I. Marquina

Otro ejemplo de esta clasificación es la Gran Greca o Gran Xicalcoliuhqui, construida por una sucesión horizontal de grandes nichos con cornisa y talud conformando un largo muro con forma de una gran espiral vista desde arriba.

Fig. 70. Gran Xicalcoliuhqui, Tajín

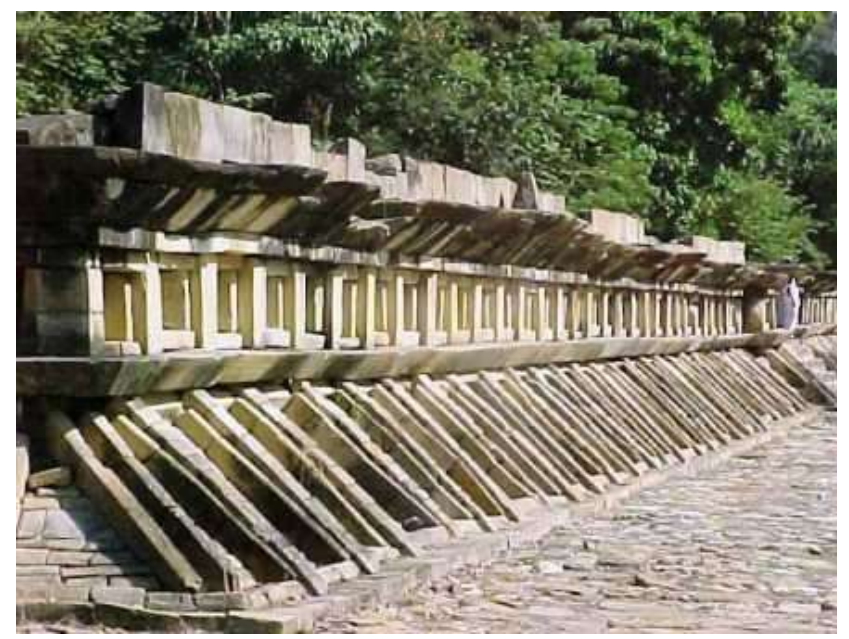

Fuente: arqueomex.com

Los nichos semi-estructurales, se pueden ver agrupados en bloques o macizos, sobrepuestos principalmente en las 
escalinatas de las fachadas de los edificios, a manera de elementos configurativos y característicos de su arquitectura.

Fig. 71. Agrupamiento de un macizo de 3 nichos consecutivos Edificio 1 Tajín.

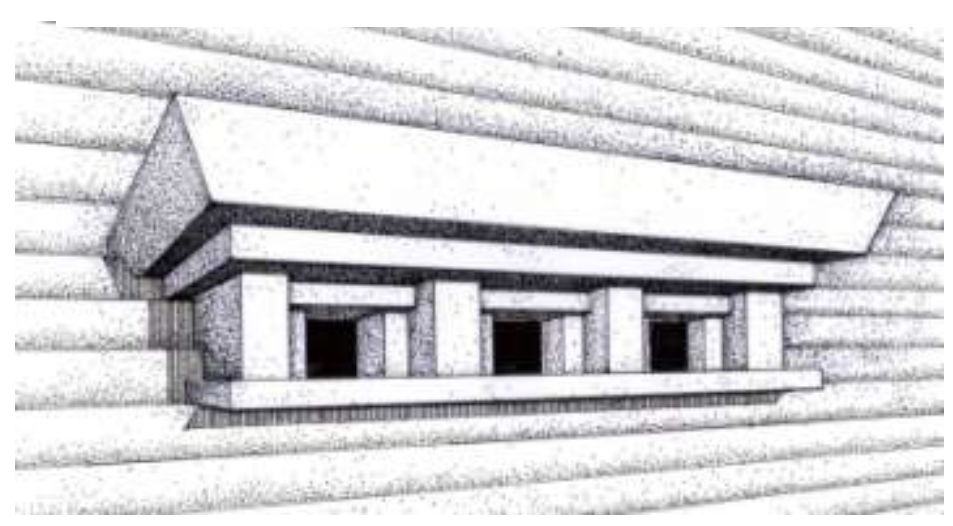

Dibujo: L. Valle

Fig. 72. Agrupamiento de un macizo de 8 nichos en secuencia horizontal procedente del Edificio 18, Grupo del Arroyo Tajín.

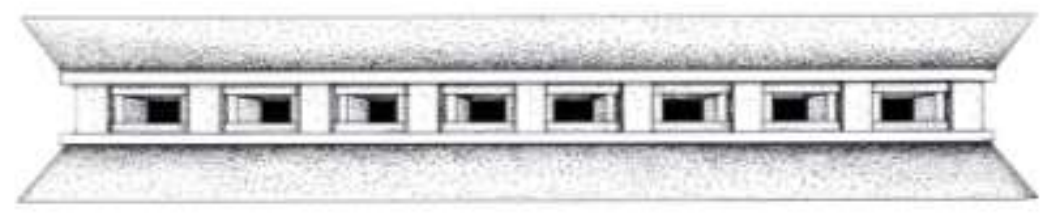

Dibujo: L. Valle 
Nichos en sucesión horizontal: como remates de basamentos y como remate del edificio.

Fig. 73. Ejemplo de remate del Edificio 5, nichos en sucesión horizontal

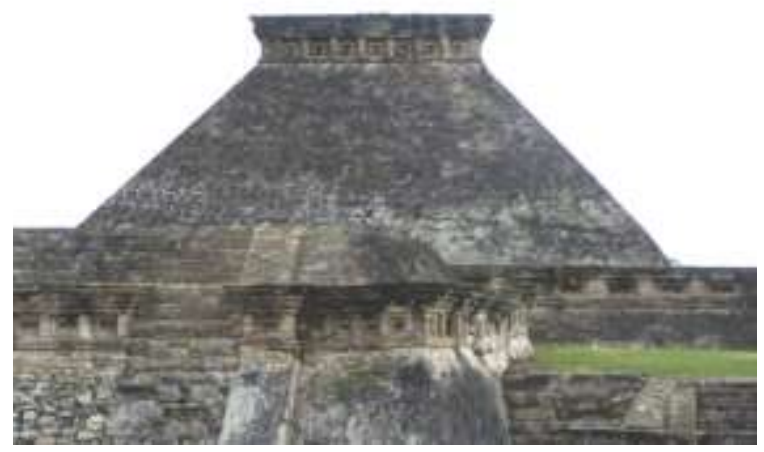

Fuente: Mexico desconocido.

Individualmente se encuentran como remates de las alfardas de las escalinatas, como en el caso del Edificio 23.

Fig. 74. Edificio 23. Izquierda; detalle de nicho.

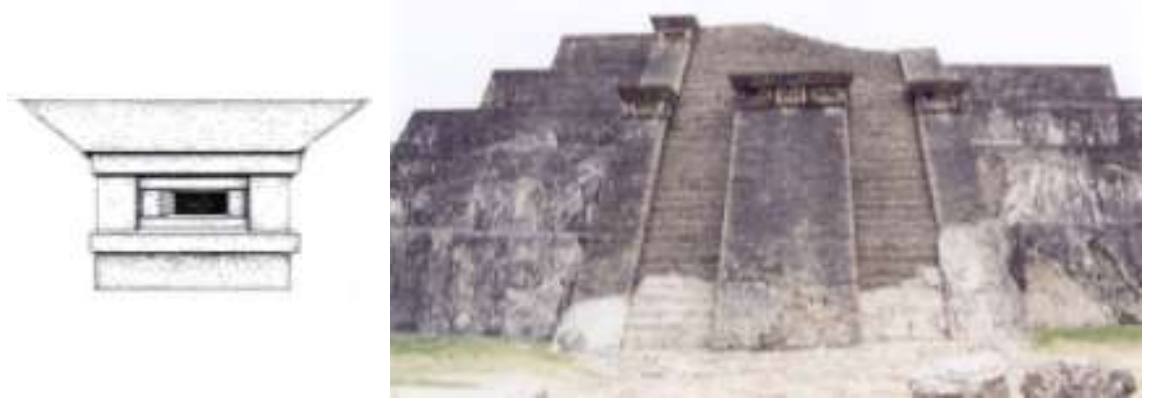

Fuente: www.latinamericanstudies.org

Combinaciones formales de nichos más complejos son:

- Nichos con greca escalonada en su interior y columnillas 
- Nichos falsos (ilusión óptica creada por la sucesión de grecas escalonadas).

- Nicho con doble greca escalonada

- Nichos dentro de otros nichos

Fig. 75. Nichos falsos formados por el espacio negativo que dejan las grecas escalonadas. Edificio C, Tajín Chico.

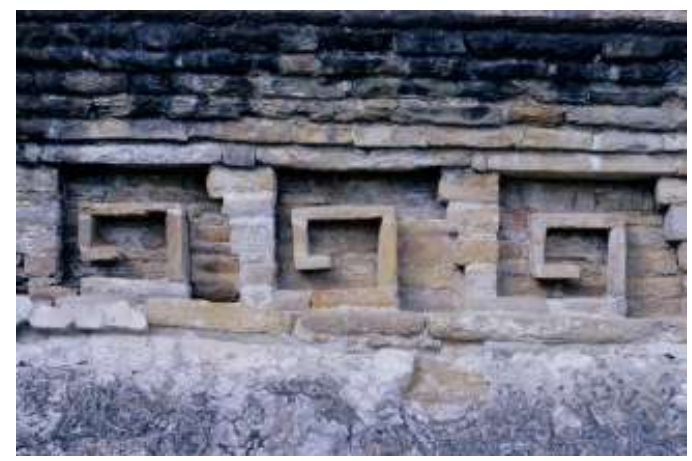

Fuente: México Desconocido.
Fig. 76. Detalle de nicho con greca escalonada en su interior y columnillas cilíndricas de marco exterior. Edificio de las Columnillas

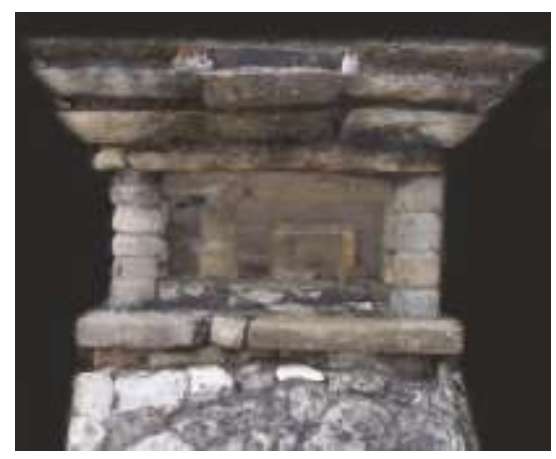

Fuente: México Desconocido.

Proporción: Presenta diversas variables de proporción que van de acuerdo al diseño de cada edificio en particular y que se verán mas adelante.

\subsection{La greca escalonada y sus variaciones formales.}

Este elemento formal, la greca, ha sido utilizado por casi todas las culturas tan antiguas como los griegos, de ahí el origen de su nombre; pero en Mesoamérica se utilizó el nombre de greca escalonada por contener en su geometría el trazo cuadrado o 
rectangular en sucesión escalonada como remate de la greca inicial. Fue utilizada por casi todas las culturas precolombinas del continente americano con sus diversas manifestaciones artísticas en Teotihuacán, por los Mayas, los MixtecoZapotecas, -especialmente en los edificios de Mitla-, los Toltecas, los Totonacas, Huaxtecos, Aztecas, etc., llegando hasta Sudamérica por ejemplo en los textiles de los Andes.

Aparece también en los libros pintados o códices, en los tejidos de su indumentaria y objetos de joyería, en la cerámica, en la escultura, etc,; incluso existen estudios sobre instrumentos musicales mesoamericanos, como el caso de la flauta totonaca triple de Tenenexpan, según los cuales la flauta emite frecuencias sonoras, que, traducidas en gráficos matemáticos, forman la greca escalonada. ${ }^{48}$

En El Tajín, la greca escalonada nombrada en lengua náhuatl "xicalcoliuhqui" tuvo gran importancia simbólica y relevancia visual; los edificios más importantes la utilizaron en sus fachadas principales o detalles arquitectónicos. Sus variantes compositivas que, si bien estaban condicionadas a la funcionalidad religiosa y sagrada, aportan a las edificaciones atracción, dinamismo, identidad, a la vez que guardan un lenguaje hermético de formas geométricas estilizadas acorde a la cosmovisión propia que invita a la reflexión. Sobre este aspecto, los estudios en el campo de la iconografia coinciden en que la greca escalonada es, en su forma primigenia

\footnotetext{
${ }^{48}$ Fuente: www.tlapitzalli.com
} 
naturalista, "la espiral" relacionada en Mesoamérica con el caracol cortado, - "ehecacozcat"- o "joyel del viento". Eso se debe a que frecuentemente la escalera de la greca aparece con una vírgula (la espiral), que también representa el aire, el habla, la voz o el sonido. El caracol cortado representa al Dios del Viento Ehécatl-Quetzalcoatl dentro de la iconografia simbólica de los dioses mesoamericanos y de las variadas manifestaciones de esta suprema y máxima deidad principal Quetzalcoatl.

Fig. 77. Caracol cortado

Cultura Huaxteca

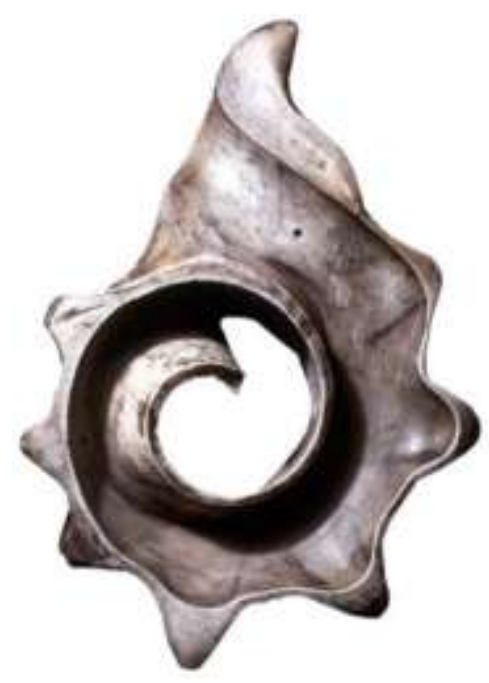

Fig. 78. Imagen pintada de EhécatlQuetzalcoatl en el Códice Borgia, portando en su pecho el símbolo del caracol cortado

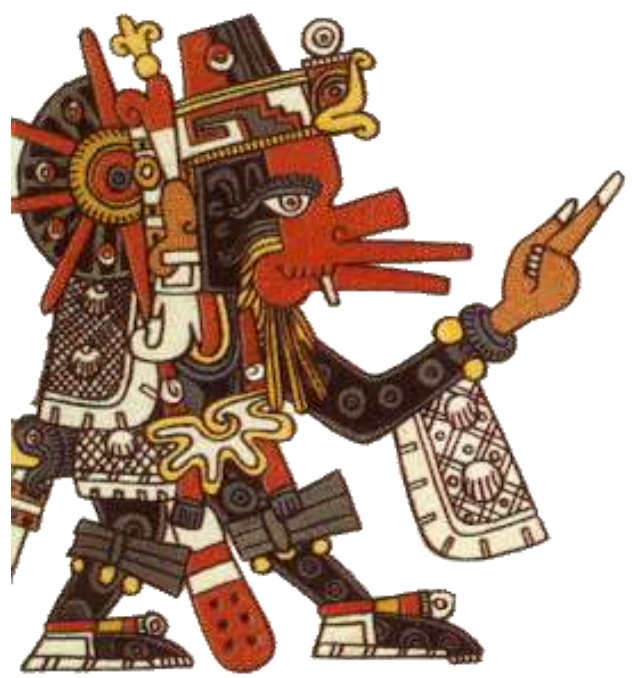

Fuente: www.arqueomex.com

Un bello poema que dedicara el escritor mexicano Octavio Paz y premio nobel de literatura a El Tajín habla de este elemento: 
El Tajín ondea con el hermoso cuerpo de la serpiente preciosa: Quetzalcoatl, el dios mayor del Tajín, la serpiente emplumada.

Tajin está lleno de serpientes entrelazadas, de nudos de serpientes, que son nudos para atar el tiempo; pero lo que más abunda en Tajin son grecas, grecas escalonadas, combinadas o simétricas, chicas y grandes.

La greca es la obsesión del hombre de Tajin, es una plegaria que se repite en la piedra, una plegaria al dios dominante Quetzalcoatl.

Porque la greca es espiral, es la espiral del interior del caracol marino donde entra el soplo sagrado del que la hace sonar.

La greca es la espiral del caracol cortado, el emblema de Quetzalcoatl-Venus que es también Dios del Viento, el viento que trae el agua del cielo que fecunda la tierra. ${ }^{49}$

Además del Dios del Viento, representaba al Dios de la Lluvia, Tláloc para los pueblos nahuas y Tajin para los totonacas. Para García Payón todo el sitio estuvo dedicado a esta deidad, “...que es la espiral circular en su primera forma, o geométrica

49 Paz, Octavio: México en la obra de Octavio Paz Vol. III, Los privilegios de la vista. Arte de México, Edición de Luis Mario Schneider y Octavio Paz, Fondo de Cultura Económica, México, 1987. 
en que devino más tarde, que representa el viento y la lluvia, es decir, el ciclón, el huracán, deidificado con el nombre de Tajín..."

La greca escalonada o "xicalcoliuhqui" parte primeramente de la forma cuadrada en su núcleo que va desdoblándose como la espiral y continua con la unión en una terminación escalonada. Su base reticular es una cuadrícula. Estas dos partes, la espiral y la escalera presentan variaciones compositivas.

Se tomará como base modular la greca escalonada de la pirámide de los Nichos para el dibujo-ejemplo a utilizar: este módulo se observa con variaciones en los escalones y en la dirección horizontal, vertical, derecha, izquierda en las edificaciones de la ciudad de El Tajin que tienen en sus fachadas este elemento simbólico.

- Asentada sobre la línea de tierra dirección derecha con 3 escalones en repetición consecutiva horizontal ejemplo Edificio de las Columnas:

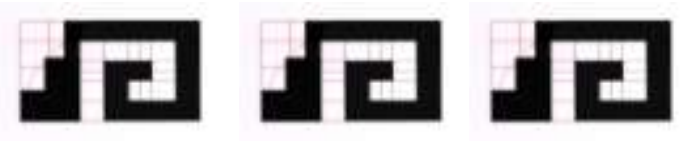

- Horizontal dirección izquierda con 3 escalones en repetición consecutiva, mismo caso anterior: Edif. de las Columnas: 


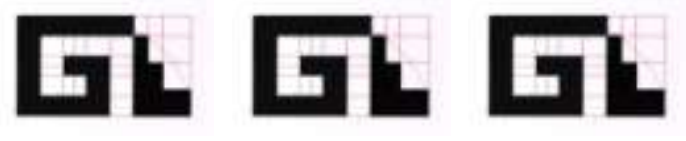

- Horizontal dirección derecha invertida ejemplo: Edif. C Tajín Chico

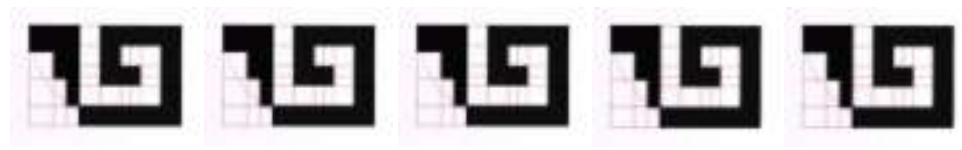

- Vertical derecha ascendente ejemplo Pirámide de los Nichos y vertical derecha descendente en el Edif. D Tajin Chico:
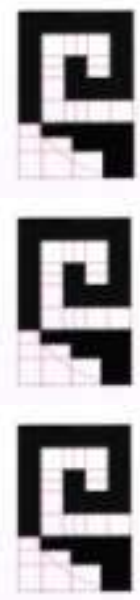
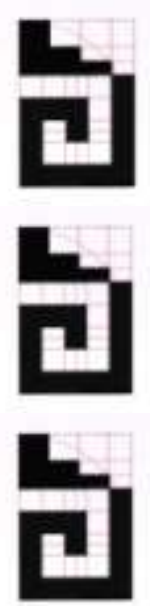

- Vertical izquierda invertida ascendente ejemplo Pirámide de los Nichos y descendente en el Edificio D, Tajin Chico 

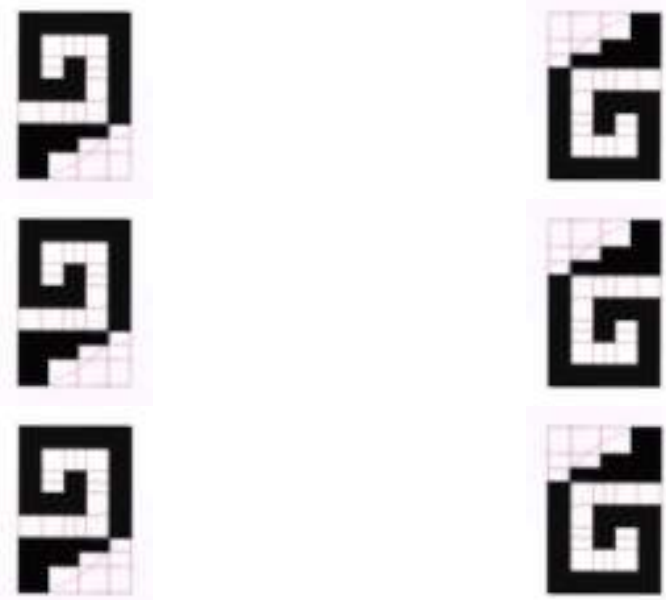

La greca escalonada como elemento formal no estructural: este ejemplo del Edificio $\mathrm{C}$ es un ingenioso engaño visual; su cuidadosa construcción hace simular nichos con grecas en su interior siendo en realidad solo grecas escalonadas en sucesión.

Fig. 79. Detalle escultórico del Edificio C.

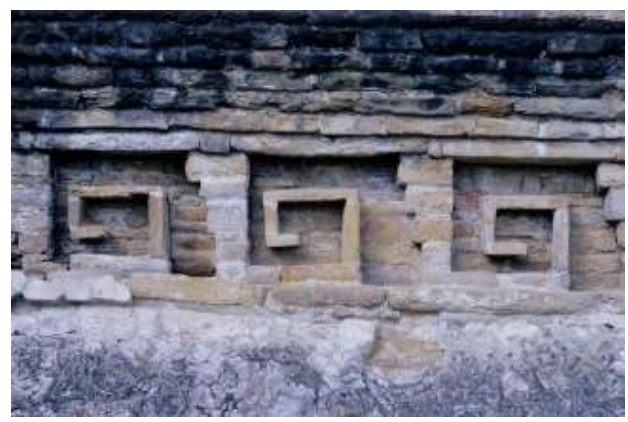

Fuente: arqueomex.com 
En alfardas de las escalinatas de los edificios:

Fig. 80. Detalle de alfardas de Pirámide de los Nichos.

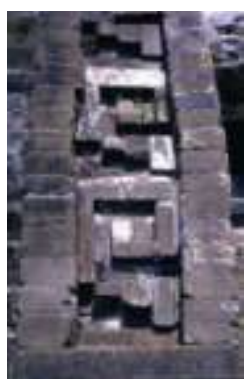

Fuente: arqueomex.com

Como remate de edificios:

Fig. 81. Detalle de Edificio 5.

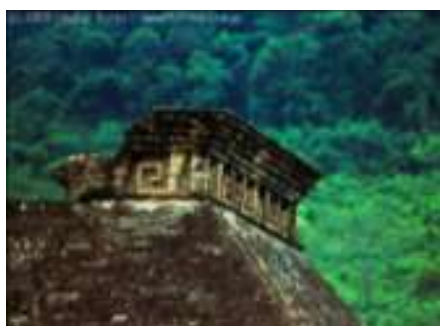

Fuente: www.fotoma.com.ar

Y elemento formal estructural.

Fig. 82. Detalle de Edificio 5. Gran Greca o Xicalcoliuhqui:

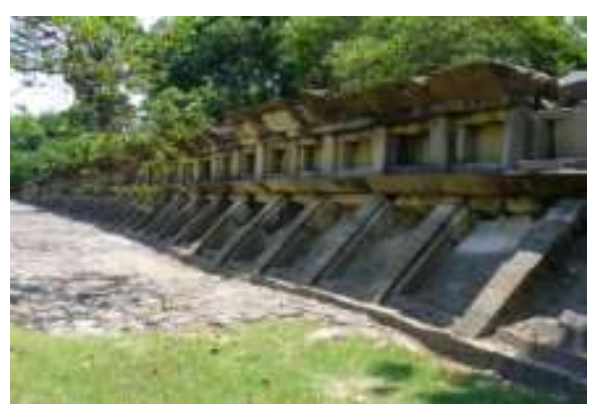

Fuente: www.fotoma.com.ar 
Aunque parezca un caso excepcional tomando en cuenta las escasas edificaciones de su tipo en otros sitios de Mesoamérica, en El Tajín la greca escalonada adquirió su máxima representación en la espectacular construcción de la Gran Greca o Xicalcoliuhqui, cuya superficie abarca 10,000 metros cuadrados y una longitud de 360 metros. Solamente vista desde arriba puede apreciarse a plenitud la forma de la gigantesca greca o xicalcoliuhqui.

Fig. 83. Acercamiento de un plano de El Tajín con la Gran Greca y el Tajín Chico.

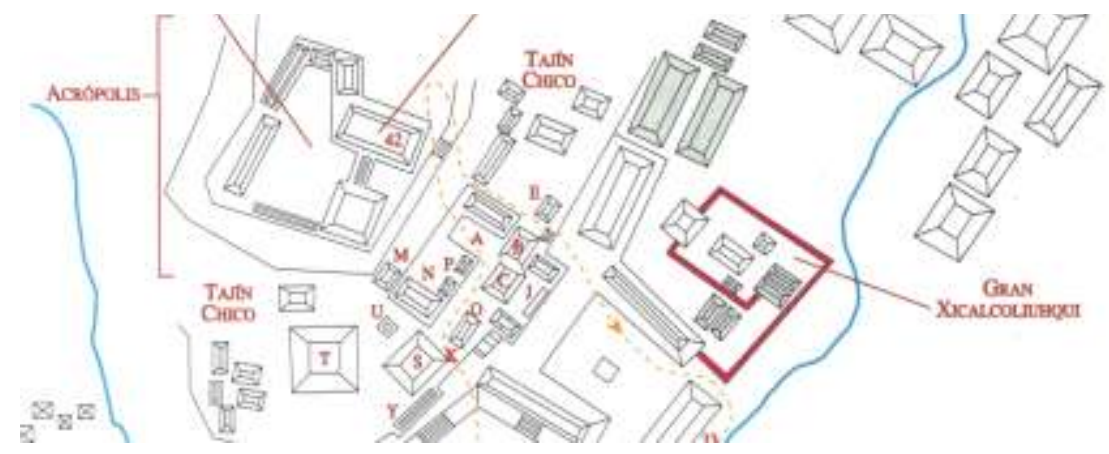

Fuente: www.arqueomex.com

Tipos de composición que adopta la greca en los edificios de El Tajin:

- Simetria axial: La simetría es la exacta correspondencia de todas las partes de una figura respecto de un centro, un eje o un plano. En el siguiente ejemplo observamos una simetría especular sobre un eje (tipo espejo). 
Fig. 84. Detalle remate de alfarda Edif. C, Tajín Chico

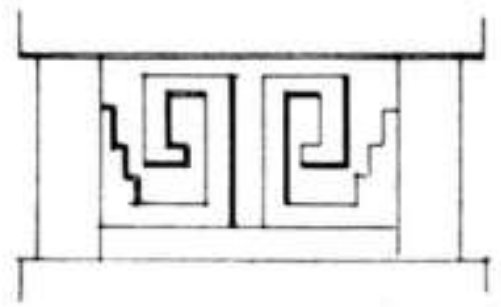

Fuente: "Arquitectura Prehispánica", Marquina

- Composición en simetria radial utilizando dos grecas girando desde un punto central, semejando una swástica. ${ }^{50} \mathrm{Su}$ diseño aparece en la fachada del Edificio A en la zona residencial de Tajín Chico. (Fuente: Marquina).

Fig. 85. Greca formando una cruz swástica. Detalle constructivo del Edificio A, Tajín Chico.
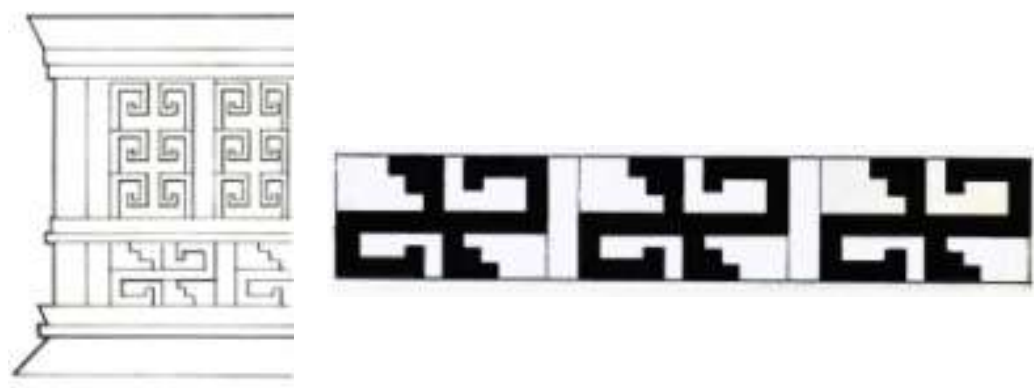

Fuente: "Arquitectura Prehispánica"

${ }^{50}$ A la swástica se le conoce también como Cruz Gamada, pues su representación gráfica tiene cuatro brazos acodados como la cruz gamma del alfabeto griego. 
- Red modular con la greca escalonada. La resultante de esta red sería una cruz muy similar a la llamada cruz chacana o cruz andina, símbolo milenario de los pueblos andinos. La cruz se utilizó en el Templo de las Columnas del Tajín Chico, en la cual la vemos ordenada bajo el sistema de retícula de cuadrados.

Fig. 86. Cruz Chacana

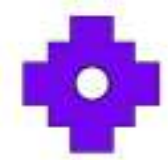

Fuente:

ccintiwatana.blogspot.com
Fig. 87. Secuencia de cruces.

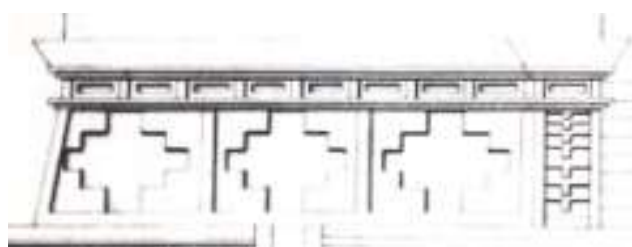

Fuente: Guía arqueológica de El Tajín de José García Payón

Fig. 88. Redes modulares de 4 grecas escalonadas en simetría axial de dos ejes.
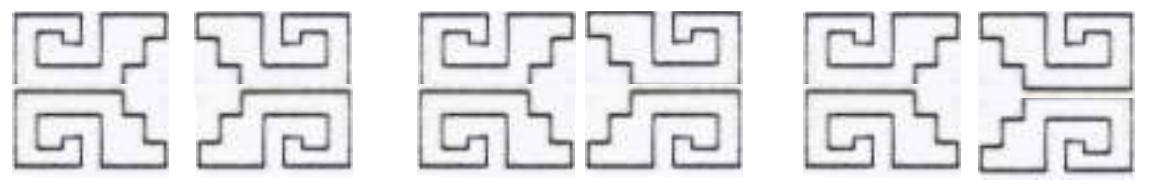

Fuente: I: Valle.

El empleo de redes modulares utilizando la greca escalonada en la arquitectura prehispánica tiene su máxima expresión visual en la ruinas de Mitla o Mictlán en Oaxaca; la greca escalonada se transforma en ilimitados juegos de combinaciones y variaciones formales esplendorosas que merecen una breve mención. He aquí algunos ejemplos de imágenes en detalle correspondientes a los muros del llamado 
Palacio de las Columnas en Mictlán y que pertenecen a la cultura mixteco-zapoteca.

Fig. 89. Detalle exterior del Palacio de las Columnas en Mitla, Oaxaca.

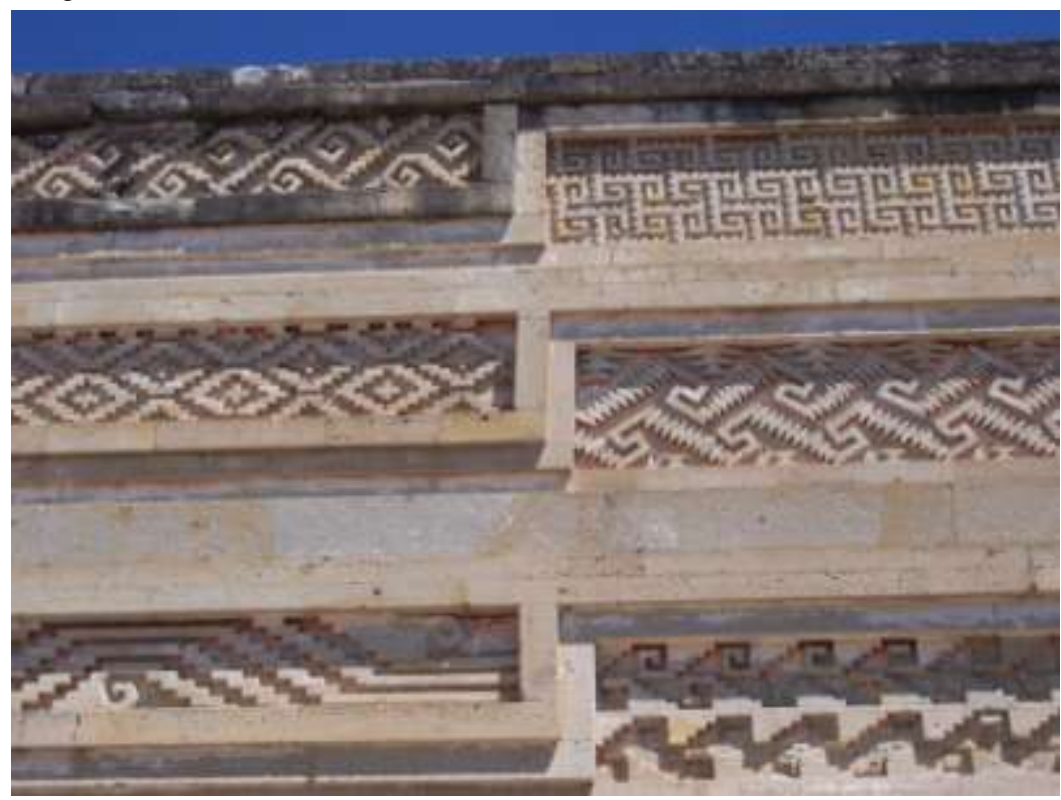

Fuente: www.skyscraperlife.com

Fig. 90. Grecas diversas en Mitla.
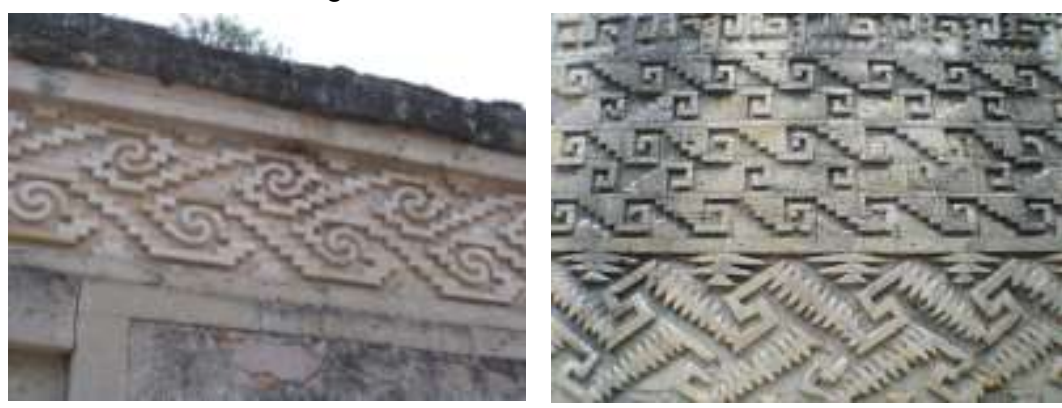

Fuente: www.skyscraperlife.com 


\section{- Fondo-figura.}

Se forma otra greca gemela (en blanco) fondo de la figura en positivo (en negro), reuniendo una doble imagen positivonegativo, que materializa el pensamiento del dualismo en la cosmovisión antigua.

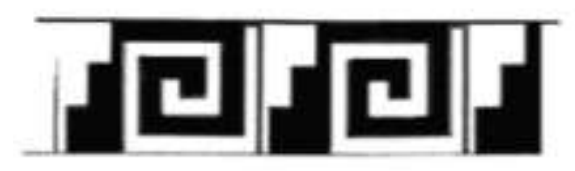

\subsection{La Cruz y los rombos entrecruzados.}

La Cruz fue un símbolo sagrado entre todos los pueblos de Mesoamérica y alrededor del mundo. En El Tajín se ha mencionado la Cruz que se forma con 4 grecas escalonadas en el ejemplo del Edificio de las Columnas. Se puede considerar también el caso de la cruz tipo swástica o cruz en movimiento que se forma con 2 grecas escalonadas en simetría radial; se encuentra en detalles escultórico-arquitectónicos en varios edificios de la zona arqueológica: Edificio A Tajín Chico, Edificio de las Columnas. 
Fig. 91. Arriba dibujo de Cruz en movimiento o swástica en positivo.

Abajo: Detalle de decoración en estuco del corredor interior del Edificio A, Tajín Chico.

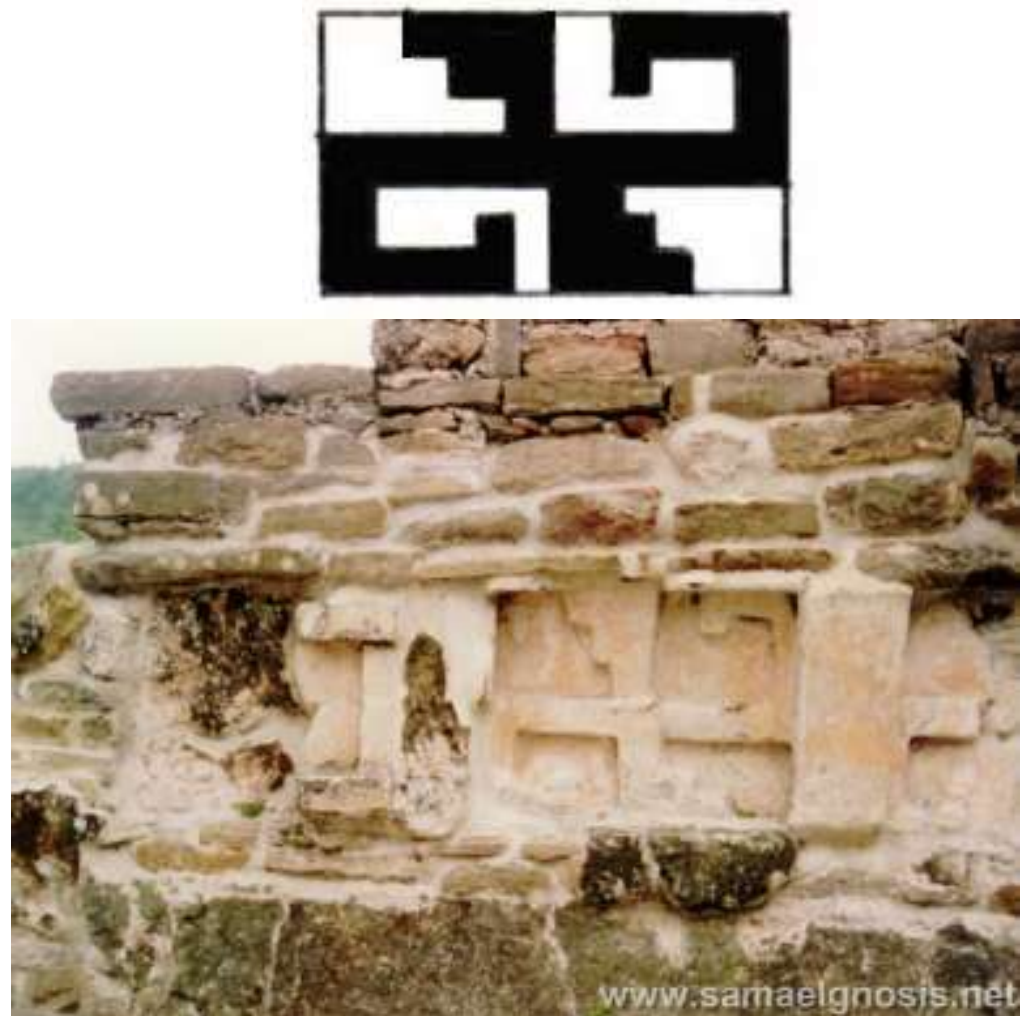

Fuente: www.samaelgnosis.net

Existe otro caso de la utilización del uso de la Cruz en los edificios 13-14, una cancha para el juego de pelota en la que la cruz que está construida en el interior de cada uno de los nichos en sucesión horizontal a lo largo del que constituye el remate superior de ambos edificios. En este ejemplo es interesante apuntar que se forma la cruz andina o chacana en el contorno exterior y, a su vez, se forma otra cruz pero del tipo griego en el espacio negativo interior del bajorrelieve. 
Fig. 92. Cancha para el juego de pelota 13-14 con acercamiento del detalle de la cruz dentro de los nichos del remate.

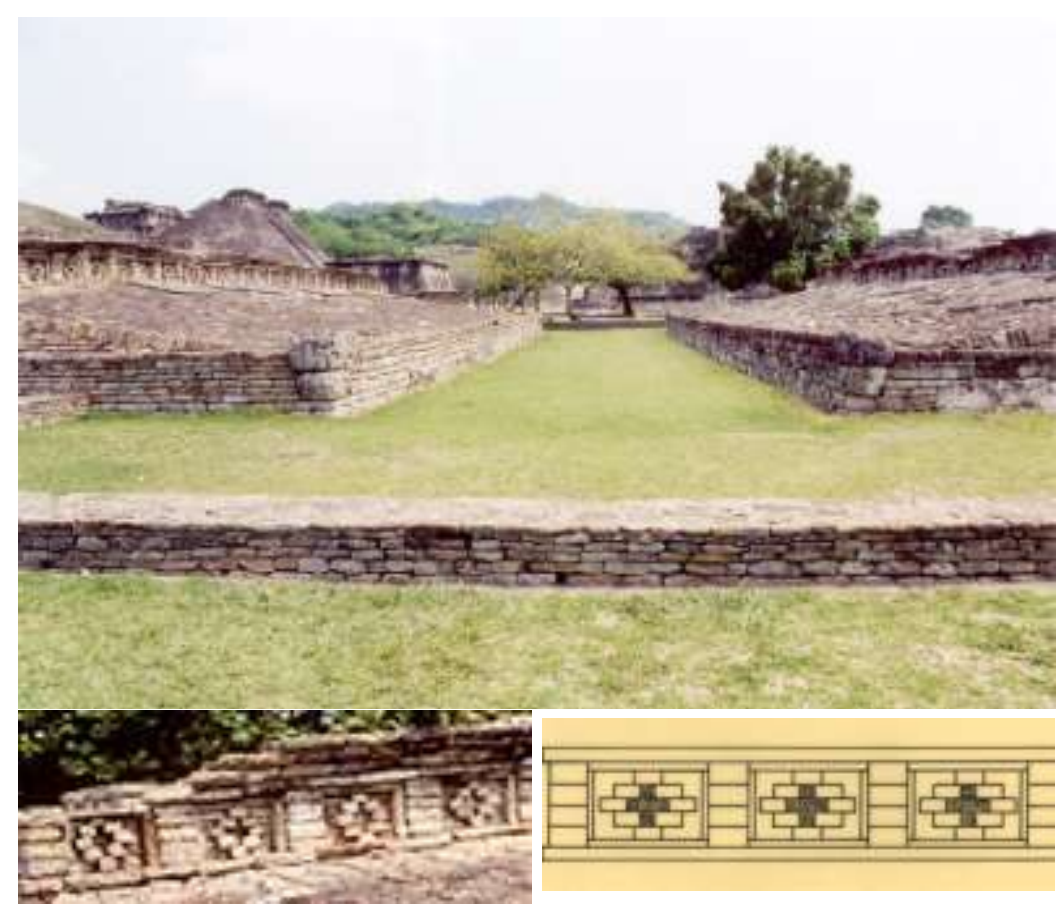

Fuente: www.latinamaericanstudies.org/Dibujo: L. Valle

Particularmente, la figura geométrica del rombo, se utilizó en el basamento del Edificio D en la zona de El Tajín Chico. Una sucesión de rombos de menor y mayor formato se entrelazan y repiten en secuencia horizontal ocupando todo el espacio del talud-basamento sobre el cual se elevaban otros dos basamentos con nichos y greca escalonada, según reconstrucción hipotética realizada por el Arq. García Payón. 
Fig. 93. Detalle escultórico del Edificio D, Tajín Chico.

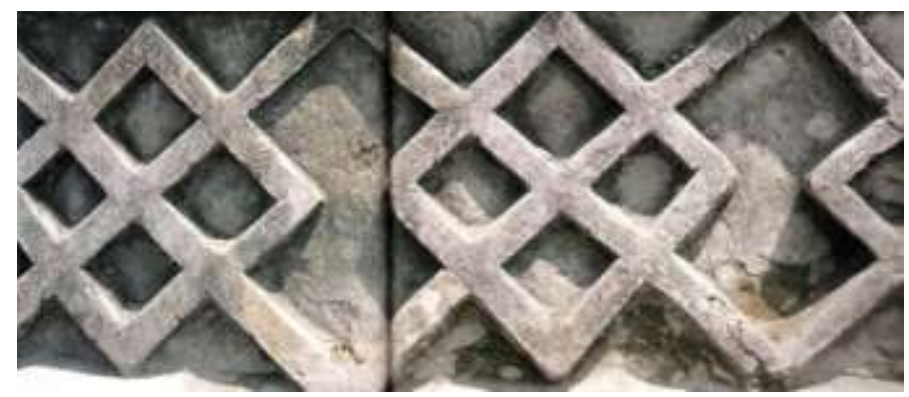

Fuente: www.arqueomex.com

Fig. 94. Reconstrucción hipotética del Edificio D.

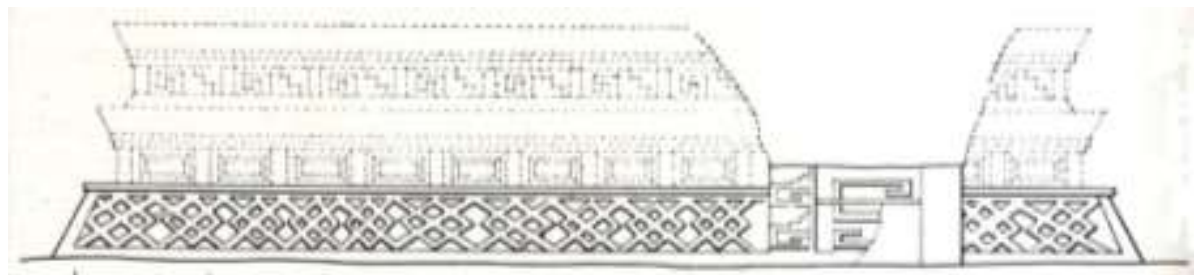

Fuente: Arq. García Payón, Arquitectura Prehispánica

Al entrelazarse los rombos, cuya altura está delimitada por el ancho del basamento, dividen al de menor tamaño en cuatro partes; este rombo fraccionado en 4 rombos menores se repite a lo largo 12 veces en la fachada del edificio, sólo interrumpido por un contrafuerte decorado con grecas escalonadas en la parte derecha; visualmente se observa un sistema reticular basado en lineas diagonales que se cruzan matemáticamente en dos direcciones dando como resultado formas romboidales de gran fuerza y dinamismo. Otro edificio con esta figura es el Edificio H, Tajin Chico, colocado en sentido vertical ascendente en las alfardas de su escalinata. 
Fig. 95. Detalle de rombos en la alfarda de la fachada sur del Edificio H, Tajín Chico.

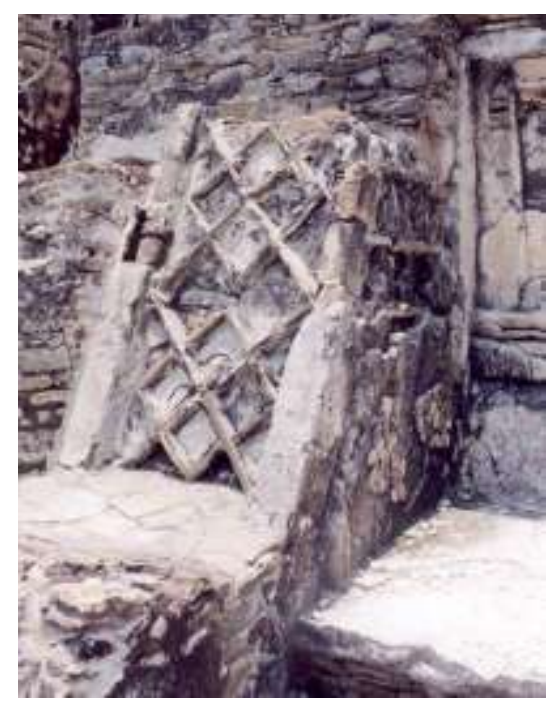

Fuente: www.latinamericanstudies.org

Los rombos fueron un motivo gráfico utilizado también en los escasos restos de pintura mural, conservados en El Tajín, así como otros elementos ya vistos como la greca escalonada, quedando de manifiesto un lenguaje visual integrador entre la arquitectura, escultura y pintura mural.

Por las características propias de esta figura geométrica es de notar que el número 4 está presente simbólicamente, y que invita a reflexionar en la cosmovisión del universo prehispánico: los 4 rumbos o direcciones en que está ordenado el cosmos, los 20 signos de los días se dividian en 4 grupos de cinco, un grupo para cada dirección cardinal, etc. 
Fig. 96. Dibujos lineales sobre ejemplos de diseños utilizando todos los elementos que se han mencionado:
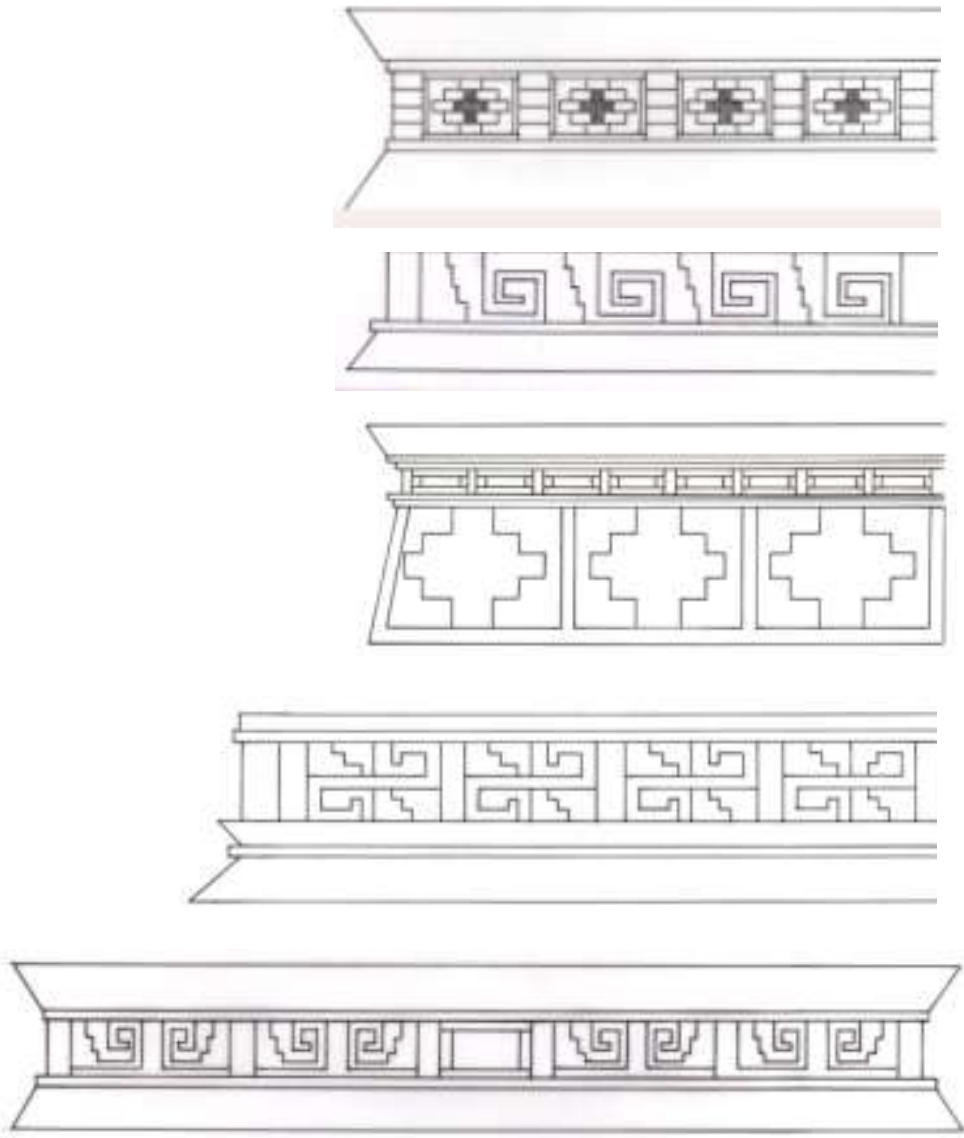

En las alfardas de escalinatas:
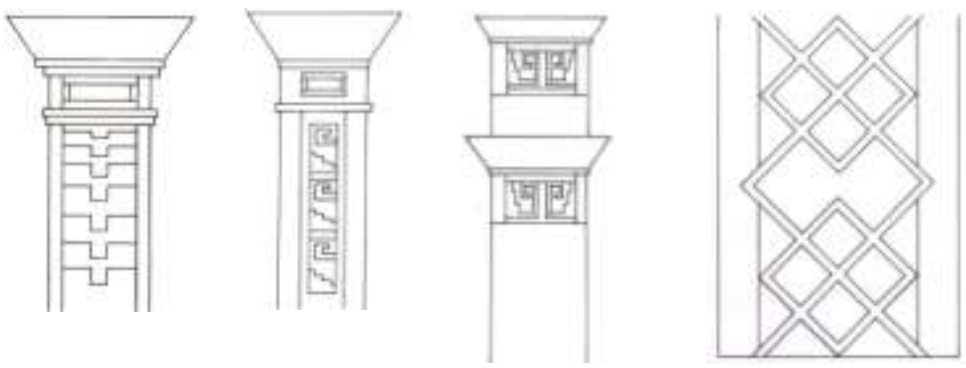
En contrafuertes:
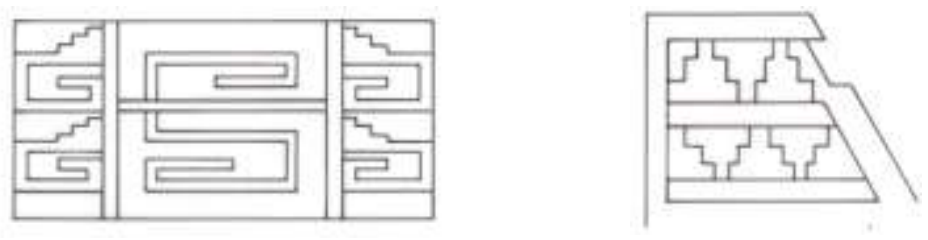

Fuente: L. Valle

\subsection{Yohualichan y otros sitios.}

Los elementos formales descritos antes también fueron empleados en otros sitios o asentamientos de menor importancia, que de acuerdo con los arqueólogos e investigadores, sin duda recibieron la influencia de la arquitectura particular de El Tajín por utilizar el nicho/cornisa volada en sus edificaciones. Tal es el caso de Yohualichan, en el Estado de Puebla. Los edificios principales son parecidos en su conformación plástica a la Pirámide de los Nichos y el Edificio 16, pues, al igual que estos, tienen hileras de nichos y cornisas en sucesión horizontal en todos sus cuerpos escalonados. En su momento estuvieron recubiertos de estuco y completamente policromados, pues todavía pueden verse restos de color rojo en algunos aplanados de sus construcciones.

Están ordenados formando una gran plaza rectangular. Cuenta también, al igual que en El Tajín, con canchas para el Juego de Pelota. El sitio está construido sobre terrazas 
construidas sobre grandes plataformas naturales, y en sus cercanías se encontraba la zona habitacional de la población.

Fig. 97. Pirámide monumental en Yohualichan, Puebla presenta un lenguaje visual similar a El Tajín.

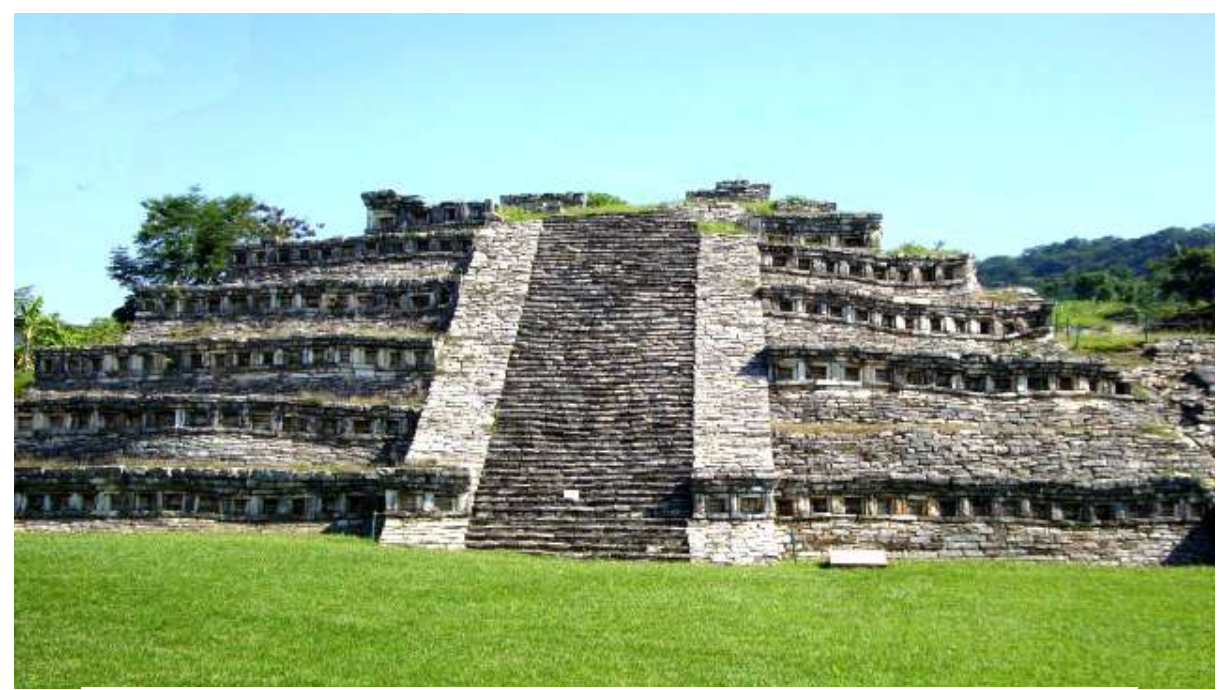

Fuente: www.tudecide.com

Otro sitio es Misantla, en Veracruz que muestra grandes cornisas voladas, aunque no se utilizó el nicho en sus construcciones: 
Fig. 98. Fachada norte del Edificio A en Misantla, Veracruz, que presenta, en medio de la escalinata, un pasadizo que conduce hacia la parte central de la plataforma superior. Es notable el remate de las alfardas en talud del edificio con el elemento formal de las grandes cornisas.

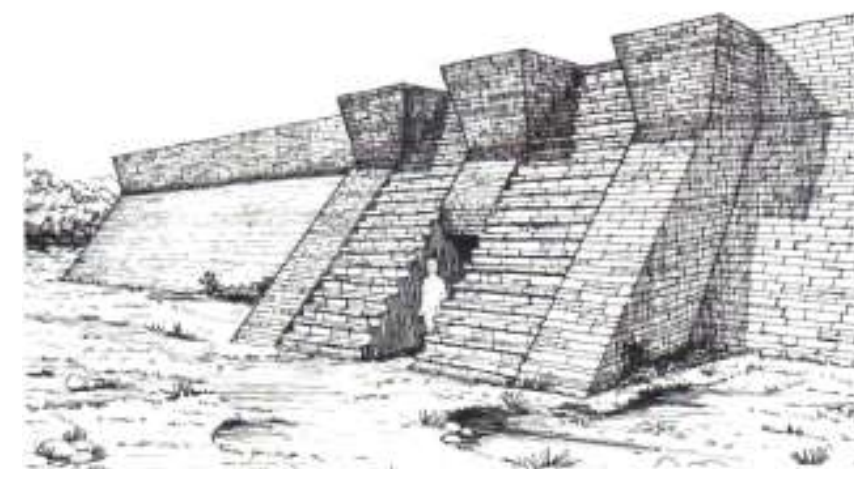

Fuente: Arte Prehispánico en Mesoamérica, P. Gendrop

Fig. 99. Cornisas semejantes en la plataforma del Edificio 5 de El Tajín.

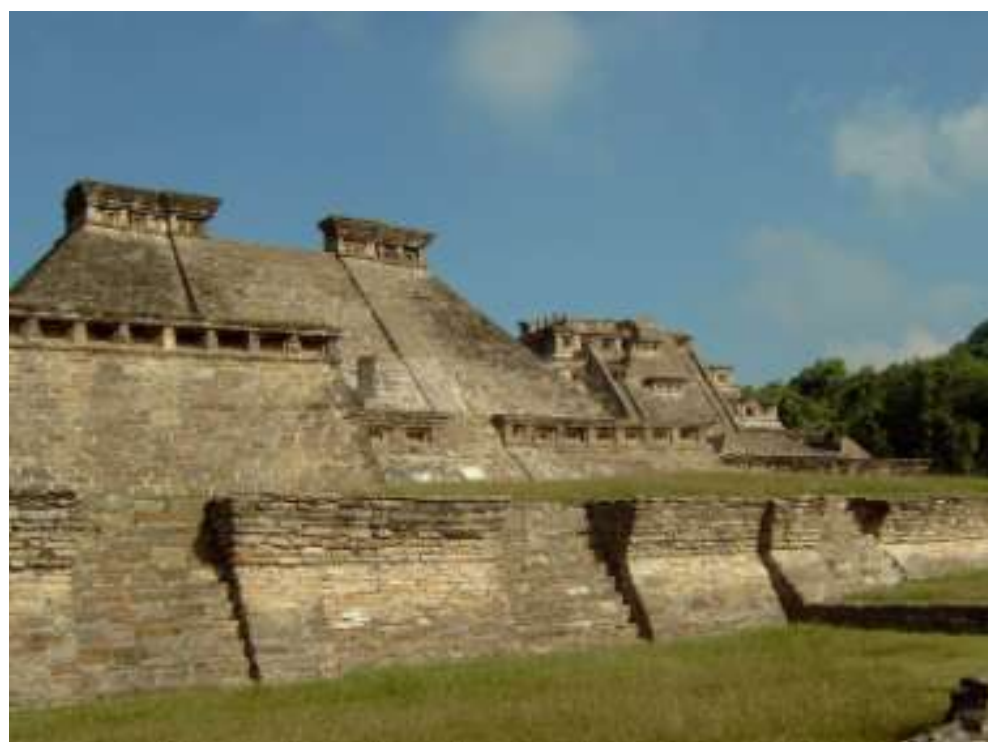

Fuente: México Desconocido. 


\section{6.- ANALISIS MORFOLOGICO DE LA ARQUITECTURA- ESCULTURA DE EL TAJIN.}

Hasta ahora se han identificado algunos de los elementos formales arquitectónico-escultóricos más sobresalientes de los edificios de El Tajín, separándolos de su contexto compositivo general y analizando sus variables visuales. Se verá a continuación cómo estos elementos se integran en un todo unitario dando la forma definitiva al edificio; aplicando algunas variaciones de escala, proporción, repetición, etc. de los mismos, y dentro de una estructura reticular, el resultado visual en todos los casos es diverso e innovador. Así, también, la sensación visual final de la forma edilicia conlleva a la percepción de ciertas cualidades plásticas sensibles: el ritmo, el movimiento, la textura, la transparencia y otras más que se han de apreciar con facilidad, ya en el camino del aprendizaje de la sintaxis visual de su lenguaje arquitectónico-escultórico.

Algunos aspectos a tener presentes antes de esto son, por ejemplo, que la forma principal de sus edificios, considerando su envolvente geométrica, es esencialmente piramidal.

La pirámide, cuerpo geométrico cuyos lados son triángulos que confluyen en un punto llamado ápice, se desarrolló en Mesoamérica como pirámide escalonada o pirámide truncada (troncopiramidal), a diferencia de las pirámides de Egipto, por 
ejemplo; en su mayoría, estas pirámides, son fieles a su forma geométrica $\mathrm{y}$, hoy por hoy, es sabido que funcionaban principalmente como mausoleos o tumbas para el descanso final de los faraones y personajes importantes. En Mesoamérica se han encontrado escasos ejemplos de pirámides destinadas a tumbas (en Palenque la de Pakal y la Reina Roja, son las más notables); mayormente funcionan como basamentos de un templo-santuario (o varios, en ocasiones) situados en la parte superior denominado teocalli ${ }^{51}$, donde residian las deidades supremas a las cuales se les rendía culto. Para llegar al templo se utilizaban escalinatas, que podían estar en cada uno de los lados del edificio. En el siguiente dibujo, basado en el libro Arte Prehispánico en Mesoamérica de Paul Gendrop, se han separado los elementos formales más importantes que configuran una pirámide escalonada:

51 Teocalli: palabra de origen náhuatl que significa Casa de Dios; $\mathrm{Cu}$ es la palabra maya para denominar templo-pirámide. 
Fig. 100. Representación de una pirámide escalonada típica teotihuacana en donde se muestran sus elementos formales generales más característicos.

\section{LA PIRAMIDE MESOAMERICANA}

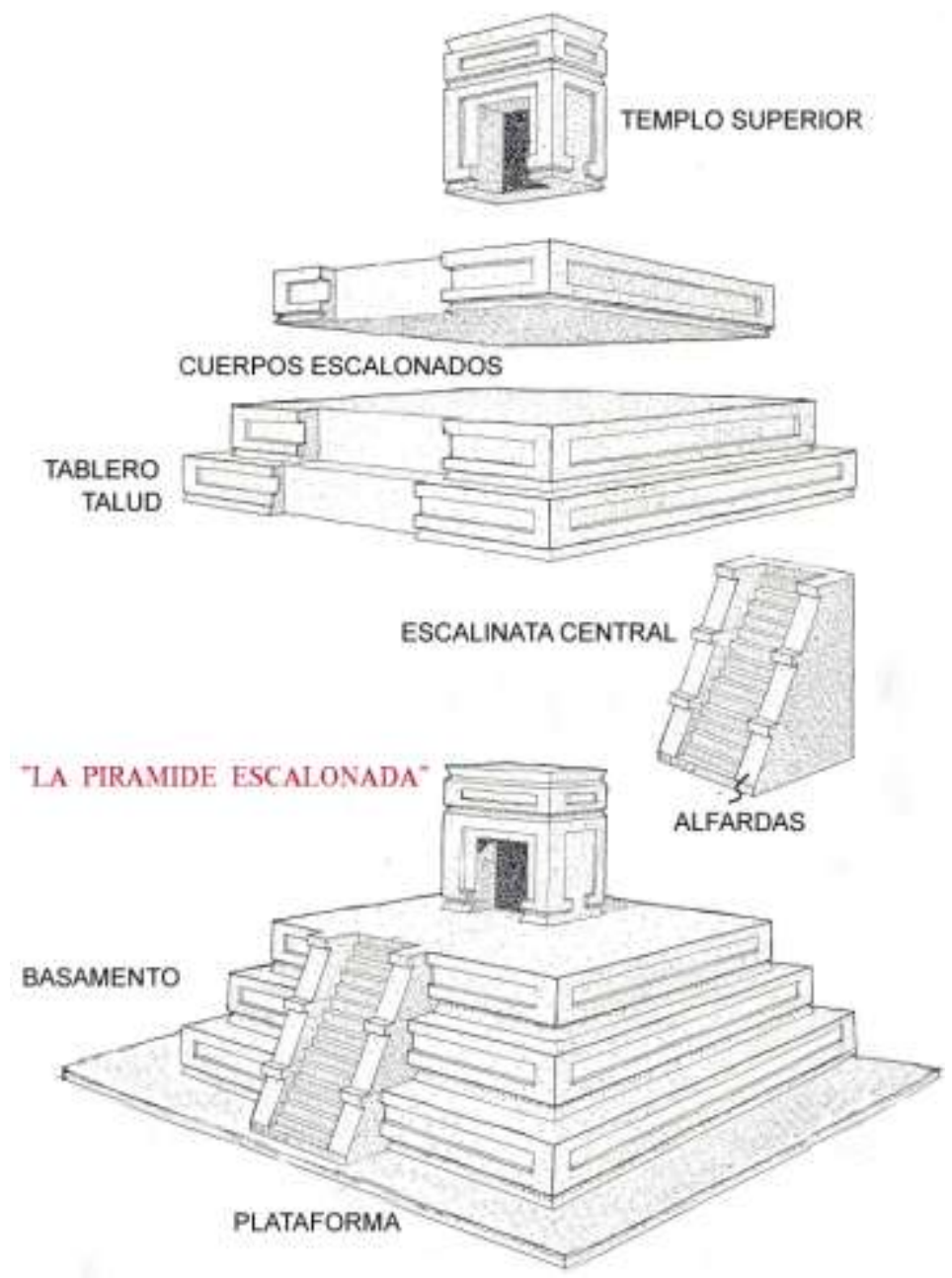

Fuente: Arte prehispánico en Mesoamérica. 
El por qué utilizar esta forma geométrica en la mayoría de los sitios prehispánicos tiene relación con el simbolismo religioso y su cosmovisión del universo. A decir de Octavio Paz, escritor mexicano y premio nobel de literatura:

La pirámide cuadrangular y escalonada es la forma canónica de la arquitectura religiosa mesoamericana. Es una proyección del cuadrilátero que forma los cuatro puntos cardinales.

(...)El modelo de la forma piramidal fue la montaña. Analogía que aparece también en Egipto, Mesopotamia y la India: el mundo es una montaña y el arquetipo de la montaña es la pirámide. En la esfera de las representaciones religiosas, la pirámide tiene un equivalente: el cielo, compuesto de 13 zonas superpuestas, y el inframundo, compuesto por nueve.

(...)La pirámide es espacio convertido en tiempo; a su vez, en la pirámide el tiempo se vuelve espacio, tiempo petrificado. La salida y la puesta del sol, los movimientos de las constelaciones, las apariciones $\mathrm{y}$ desapariciones de la luna, de Venus y de los otros planetas, rigen la orientación de las pirámides y su relación con las otras construcciones. ${ }^{52}$

52 portal.sre.gob.mx/italia/pdf/octaviopaz.doc 
Existen ejemplos notorios de ello como la Pirámide de Kukulcán en Chichén Itzá, la Pirámide del Sol y la de la Luna en Teotihuacán, la de Xochicalco en Morelos, Tenayuca en el En el estado de México, en El Tajín, sobresale la Pirámide de los Nichos y otros casos más; en la actualidad los estudios sobre la relación de los yacimientos arqueológicos con los conocimientos que tenían las culturas antiguas sobre astronomía están a cargo de la arqueo-astronomía ciencia que ha logrado ahondar sobre estos aspectos de gran interés.

De acuerdo a diversas opiniones, las pirámides de Mesoamérica están construídas en base a la proporción humana, como en otras civilizaciones del mundo antiguo. La doctora María Teresa Uriarte afirma que el cuerpo humano es la base de las medidas de los edificios prehispánicos y no solamente en escala, sino que también formó parte del diseño en sus construcciones. Ejemplo de ello son los atlantes de Tula, Hidalgo, monolitos humanos que sostenian la techumbre de un edificio superior. ${ }^{53}$ En El Tajín se sabe que en la fachada de algunos edificios estaban en pie esculturas de bulto que representaban personajes de alto rango por la indumentaria que portaban. En el templo superior de la Pirámide de los Nichos había originalmente dos esculturas de sacerdotes colocadas a ambos lados de la entrada, mismas que se pueden apreciar hoy en día en el Museo del Sitio. En el Edificio 5 se encuentra colocada la imagen prismática del Dios Tajín, cuya

53 Uriarte, María Teresa, Las pirámides y la integración plástica, en Arqueología Mexicana, Vol. XVII, Núm. 101 pág. 53. 
representación es estilizada y muestra varios puntos de vista del mismo.

Además de pirámides, en El Tajín, y en general en las grandes ciudades, se construyeron otro tipo de edificaciones de carácter civil denominados palacios residenciales destinados para los miembros de la elite sacerdotal y gobernantes.

Atención especial merecen otras construcciones únicas en Mesoamérica donde se llevaba a cabo un ritual de gran importancia: los campos para el Juego de Pelota. Hasta la fecha se han localizado alrededor de 1500 canchas distribuidas en la mayoría de los centros prehispánicos. Hay sitios como Cantona, Puebla que tiene 24 campos, en Chichén Itzá 19, en El Tajín se encontraron por el momento 17, de ahí que se considera de gran relevancia este rito.

Las canchas de El Tajín, como la mayoría de sus edificios, cuentan con los elementos formales característicos de su arquitectura (nichos, cornisas voladas, talud, tablero, etc.). El estudio particular de las canchas de El Tajin se puede consultar en trabajos anteriormente realizados. 54 Solo se mencionan aquí sus componentes formales y bajorrelieves.

Las edificaciones principales del sitio están distribuidas en zonas urbanas distinguibles por sus características topográficas, de status político, social y religioso: Grupo del

\footnotetext{
54 Para mayor información al respecto consultar la tesis de Laura Pescador: "Los juegos de pelota en El Tajín” ENAH, 1992.
} 
Arroyo, Tajín Central, Tajín Chico y Complejo de las Columnas.

Se toman casos de estudio dentro de estas grandes zonas; mencionando los elementos formales utilizados en su composición estructural, así como características importantes, tipología (según de qué tipo de construcción se trata: pirámide, palacio residencial, etc.), sistema constructivo y materiales empleados, geometría compositiva y comentarios acerca de un posible discurso de la imagen, permitiendo reconocer su lenguaje visual.

Para la descripción de la geometría de los edificios, se emplea una terminología basada en la propuesta del investigador de sistemas de composición de las culturas antiguas de América, César Sonderenguer ${ }^{55}$, la cual es la siguiente:

- Rectángulo general: RG. Envolvente general.

- El cuadrado Raíz 1: CR1. Fundamento geométrico de todo rectángulo. Fundamento mítico, símbolo de la Tierra, de los cuatro puntos cardinales, etc.

- Rectángulo Raíz 2: RR2. Rectángulo obtenido por el abatimiento de la diagonal del cuadrado.

- Rectángulo Raíz 3: RR3. Obtenido por el abatimiento de la diagonal del RR2.

- Rectángulo Áureo: RA. Rectángulo obtenido por el abatimiento de la diagonal de la mitad del lado del cuadrado.

55 Sonderenger César, Sistemas compositivos amerindios, Buenos Aires Argentina, Ediciones Corregidor, 2000, pág. 11 
- Gnomon GN: Punto originado por el cruce de dos líneas perpendiculares, oblicuas o curvas utilizados en el diseño de la obra.

- OO: Eje axial que establece la simetría del diseño.

Fig. 101. Los trazados compositivos empleados en Amerindia: el cuadrado, la Grilla, el Rectángulo Raíz 2 y el Rectángulo Áureo.

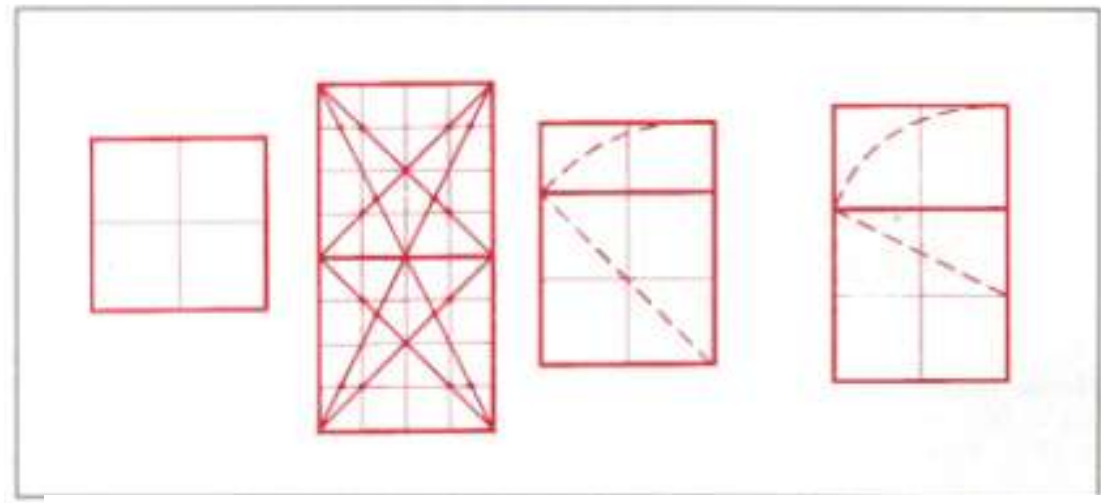

Fuente: Sistemas compositivos amerindios. C. Sonderenguer.

Otra cuestión a resaltar es que solamente se emplean las fachadas principales de los edificios casos de estudio, algunas de las cuales se obtuvieron de levantamientos originales de planos arquitectónicos del Proyecto Tajín y otras fueron dibujadas por la autora de la presente investigación. 


\subsection{Edificios de la Plaza del Arroyo.}

Esta zona se encuentra ubicada en la parte sur de la zona arqueológica, justamente en la entrada al sitio; de acuerdo a los estudios es la parte más baja de la ciudad y donde se construyeron los primeros edificios durante la Fase I. Se analizarán las 4 estructuras piramidales de carácter monumental: Edificios 16, 18, 19 y 20, distribuidos según el estilo clásico mesoamericano, es decir, uno en cada esquina dentro de un área cuadrangular, quedando un espacio central para una gran plaza toda recubierta de piedra laja.

En cuanto al sistema constructivo y materiales utilizados, ya que es común para los 4, de acuerdo con el Dr. Piña Chan, tienen un núcleo de tierra apisonada y revestidos por muros de contención de piedra.

Actualmente presentan una lectura incompleta de su diseño original ya que los templos superiores en su mayoría están en ruinas, quedando sólo restos de su estructura inferior que hace suponer de la existencia de dichas construcciones. Esto se tomó en cuenta al realizar los dibujos correspondientes y es necesario aclarar que para su análisis se consideró sólo lo que actualmente se puede apreciar en cada caso.

En el siguiente plano se muestran los edificios, caso de estudio en este capítulo, indicados con rojo. 
Fig. 102. Mapa de la zona del Tajín.

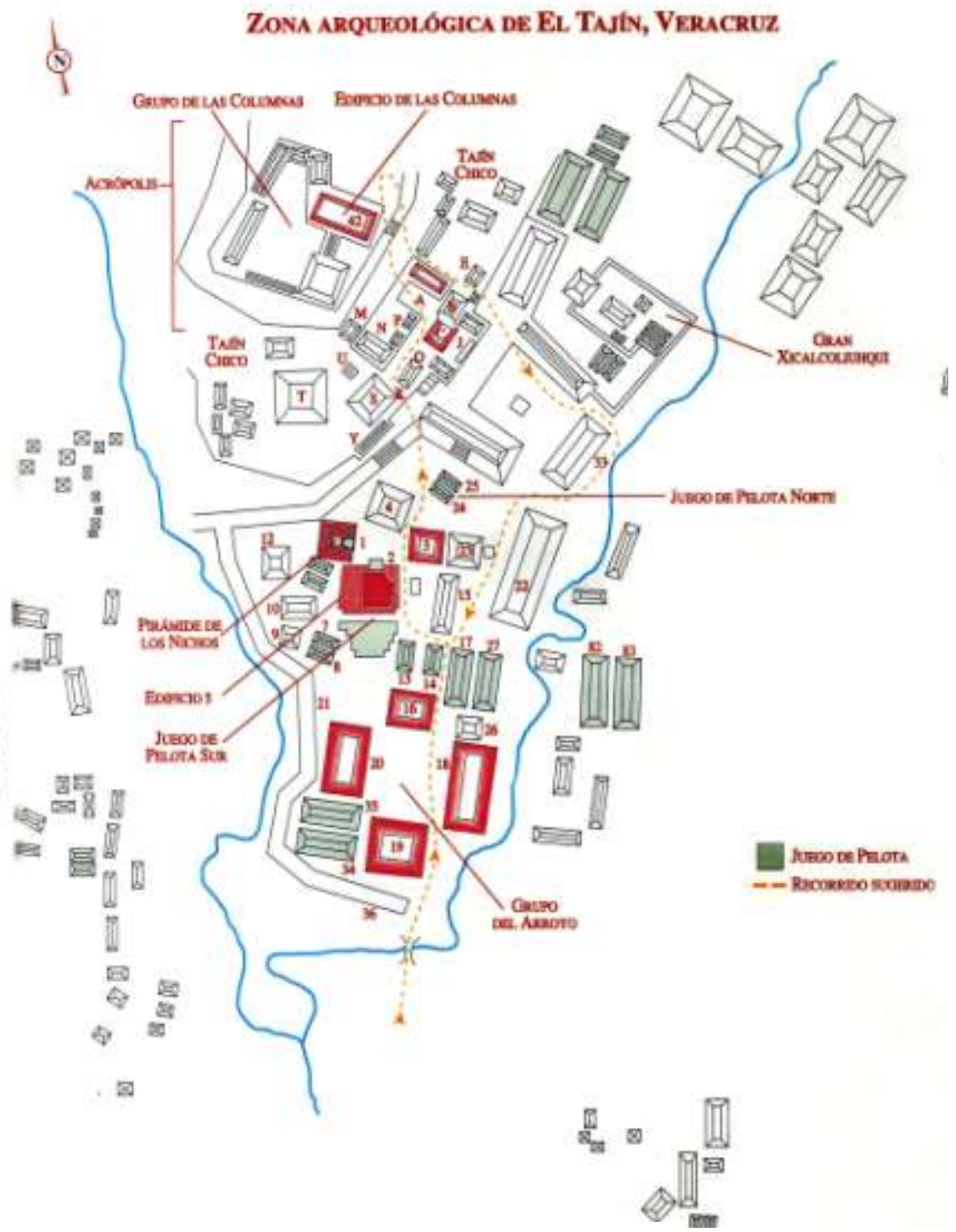

Fuente: Arqueología Mexicana 


\section{EDIFICIO 19.}

Ubicación: al sur de la Plaza del Arroyo.

Características morfológicas:

- Basamento piramidal con un templo superior incompleto.

- Planta rectangular casi cuadrada

- 18 cuerpos escalonados

- Escalinatas en sus cuatro lados; en fachada norte y sur tiene escalinata central con alfardas laterales y con 4 macizos de 7 nichos en el centro.

Fig. 103. Traza geométrica Edificio 19.

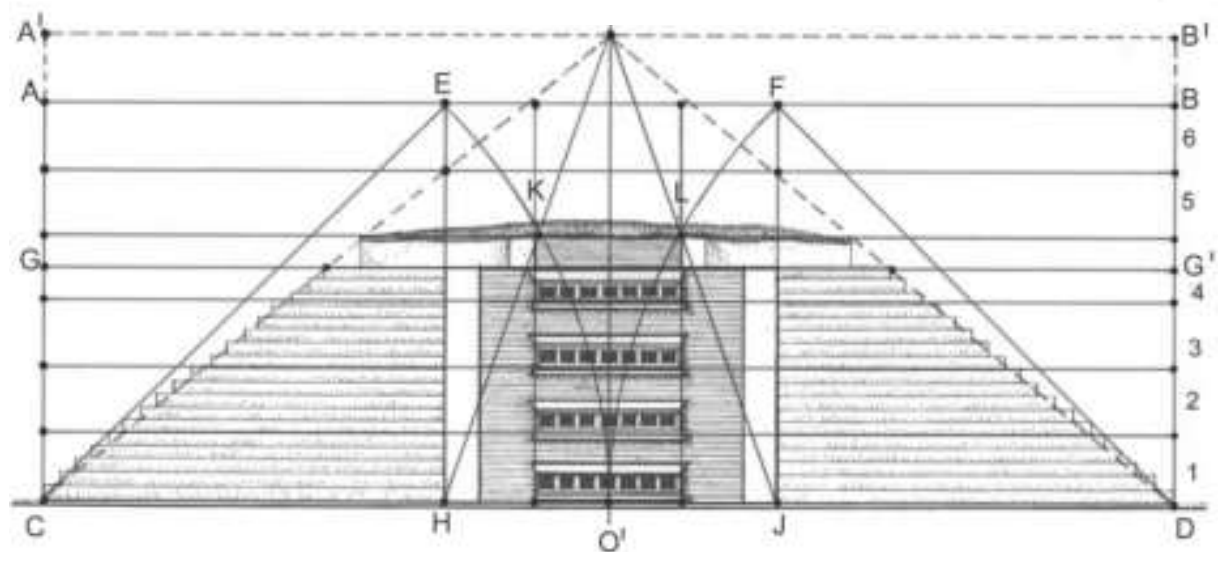

Fuente: L. Valle

ABCD: $\boldsymbol{R} \boldsymbol{G}$ formada por dos $\boldsymbol{R} \boldsymbol{R 2}$ : abatimientos $\mathrm{CEO}^{\prime}$ y $\mathrm{CFO}^{\prime}$. El segmento AC se divide en 6 partes iguales. Se proyecta la distancia de una de las 6 partes hacia arriba de A y se obtiene $\mathrm{A}^{-} \mathrm{y}$ la recta $\mathrm{A}^{\top} \mathrm{B}^{-}$. Se unen $\mathrm{CO}$ y $\mathrm{DO}$, diagonales virtuales del edificio. La parte media de la recta $\mathrm{CA}^{\prime}$ es el punto $\mathrm{G}$ que se 
prolonga hasta $\mathrm{G}^{\prime}$ que es la altura de los 18 cuerpos o basamentos escalonados. Los puntos gnomónicos $\mathrm{K}$ y $\mathrm{L}$ proyectados muestran el ancho de los macizos de nichos centrales así como del ancho de la escalinata del templo incompleto de la parte superior del edificio.

Muestra, asimismo, el equilibrio entre la horizontalidad de sus cuerpos compositivos con la verticalidad de las 4 escalinatas relacionadas con la cosmovisión y simbolismo mesoamericano. $\mathrm{Su}$ sencillez y economía visual lo diferencian de los demás edificios; no obstante, comparte con ellos el hecho de utilizar macizos de nichos en las escalinatas. Tiene una relación de posición frente al Edificio 16; presentan similitud en proporción y escala, no así con los restantes edificios de la plaza (el 19 y 20). El peso visual recae, justamente, en la parte central debido a las hileras de macizos, centrando la atención en estas estructuras.

\section{EDIFICIO 16.}

Ubicación: al norte de la Plaza del Arroyo.

- Basamento piramidal con dos templos superiores incompletos.

- Planta rectangular casi cuadrada.

- 5 cuerpos escalonados compuestos cada uno de hileras de nichos continuos sobre talud y rematados con cornisa volada.

- Escalinatas en Fachadas Norte y Sur con alfardas en sus laterales rematadas con nicho con cornisa y una 
ancha alfarda central rematada en la parte superior con un macizo de 4 nichos.

Fig. 104. Geometría Edificio 16.

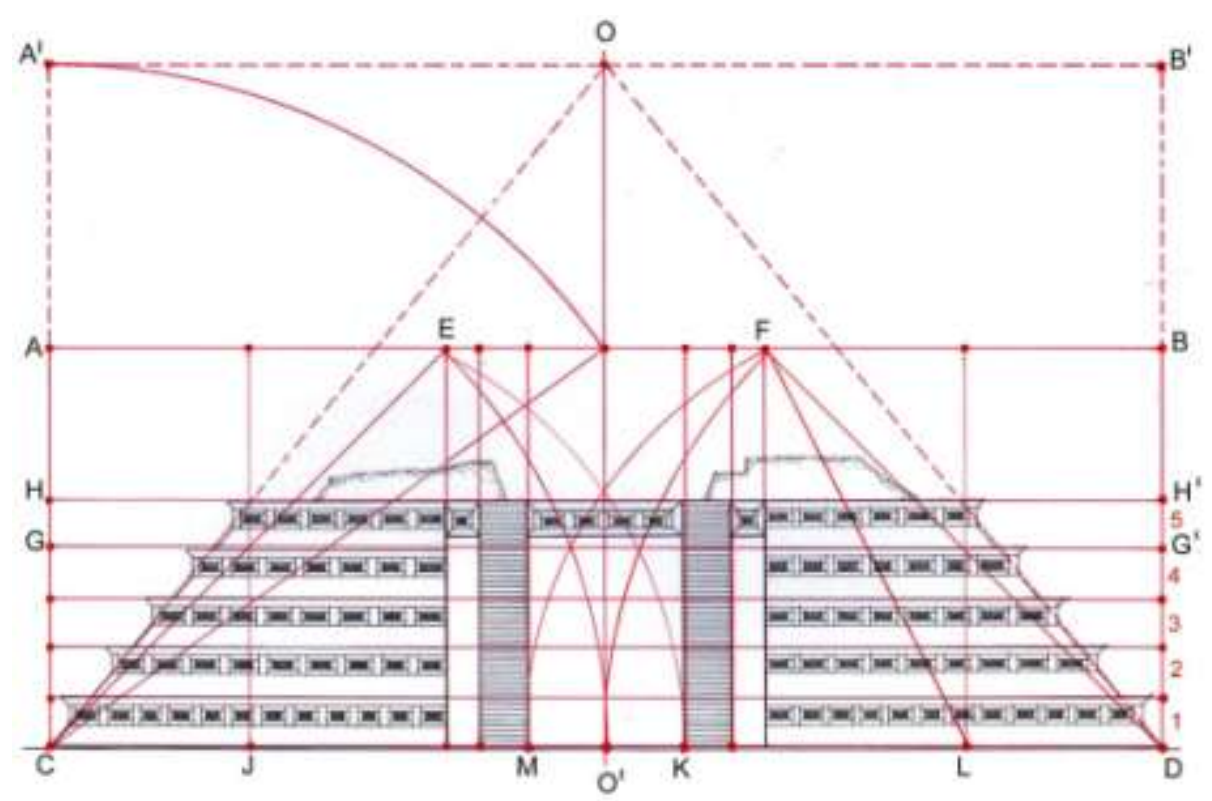

Fuente: L. Valle

ABCD: $\boldsymbol{R G}$ compuesto por dos $\boldsymbol{R} \boldsymbol{R 2}$ : abatimientos $\mathrm{CEO}^{-} \mathrm{y}$ DFO'. Abatimientos RA: JEK y LFM establecen el ancho de la gran alfarda central. La recta AC se divide a la mitad en el punto G; GC se divide en 4 partes iguales obteniendo la altura de cada basamento escalonado, prolongando esta medida hasta el punto $\mathrm{H}$.

Análisis morfológico: Su diseño compositivo, basado en hileras de nichos estructurales, es similar a la Pirámide de los Nichos, aunque de menor altura y base rectangular. Este edificio tiene la característica de tener doble funcionalidad dentro del 
urbanismo, ya que su fachada posterior es la que cierra la cancha de juego de pelota 13/14 y su fachada principal da a la plaza. El único juego de cuatro macizos de nichos está ubicado en el último cuerpo de la pirámide sobre una ancha alfarda central, a diferencia de los otros edificios que los utilizan a lo largo de toda la escalinata; por la ley gestáltica del agrupamiento (ver Tema 4) es posible percibir una línea de cerramiento compositiva superior, dada por una secuencia de nichos en hilera horizontal. La oquedad de sus nichos repetidos en todo el basamento le confiere propiedades de

cambios lumínicos, claroscuros, contrastes durante el transcurrir de la luz natural sobre ellos a diferentes horas del día; es cuando se puede percibir con un poco de agudeza la cualidad visual del movimiento.

\section{EDIFICIO 18.}

Ubicación al Oriente de la Plaza del Arroyo.

- Basamento piramidal con dos templos y un altar incompletos.

- Planta rectangular (es el de mayor longitud de los cuatro).

- 7 cuerpos escalonados.

- 3 escalinatas con sendas alfardas laterales y separadas por un espacio entre ellas. Las escalinatas tienen 4 macizos de 3 nichos superpuestos en cada una sumando en total 12 . 
- En la base hay 3 macizos de 8 nichos distribuidos equilibradamente

Fig. 105. Geometría Edificio 18.

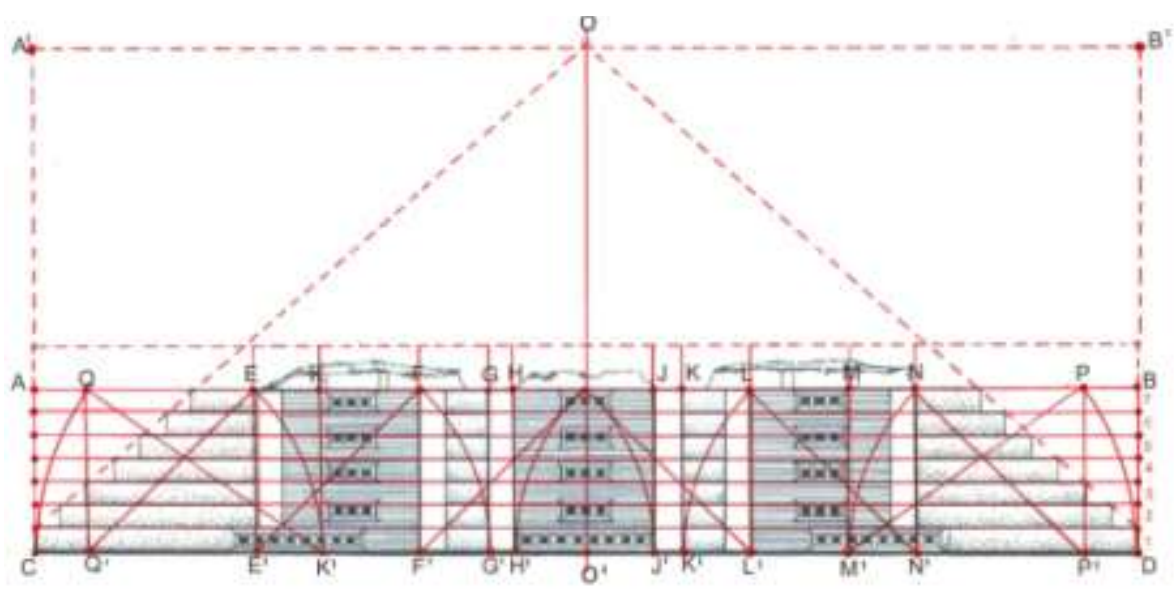

Fuente: L. Valle.

ABCD: $\boldsymbol{R} \boldsymbol{G}$ conformado por $6 \boldsymbol{C R} \mathbf{1}$ mas dos abatimientos $\boldsymbol{R} \boldsymbol{R} 3$ : $\mathrm{K}^{\prime} \mathrm{QC}$ y $\mathrm{M}^{\prime} \mathrm{PD}$. Abatimientos RR2: $\mathrm{Q}^{\prime} \mathrm{EK}^{\prime}, \mathrm{E}^{\prime} \mathrm{FG}^{\prime}, \mathrm{F}^{\prime} \mathrm{OJ}^{\prime}, \mathrm{P}^{\prime} \mathrm{NM}^{\prime}$, $\mathrm{N}^{`} \mathrm{LK}^{\prime}, \mathrm{L}^{\prime} \mathrm{OH}^{\prime}$ forman puntos gnomónicos $\mathrm{E}, \mathrm{K}, \mathrm{F}, \mathrm{G}, \mathrm{H}, \mathrm{J}, \mathrm{K}, \mathrm{L}$, $\mathrm{M}, \mathrm{N}$ con sus correspondientes primas, dentro del diseño general del edificio. H'J' establece ancho de escalinata central, que es la misma medida de las otras dos escalinatas. AC se divide en 7 partes que es la altura de los 7 basamentos de la pirámide.

Este es un edificio muy alargado en comparación con los dos anteriores, siendo el más grande de los cuatro. Prevalece en la composición la horizontalidad (lo terrenal) sobre la vertical (lo celestial); sin embargo, para lograr el equilibrio, se colocaron 
tres juegos de escalinatas con alfardas separados unos de otros, en lo que se forma un ritmo entre dos direcciones: horizontal-vertical, ascendente-descendente, arriba-abajo, etc. Los juegos de macizos en cada escalinata y en la base lo hacen partícipe dentro de los otros edificios de la plaza. Impera el uso repetido del número 3 en este diseño: tres escalinatas, tres macizos en la base o primer cuerpo, macizos de tres nichos, tres construcciones en la parte superior.

\section{EDIFICIO 20.}

Ubicado al Este de la Plaza del Arroyo.

- Basamento piramidal con dos templos y un altar incompletos.

- Planta rectangular.

- 7 cuerpos escalonados.

- 3 escalinatas con alfardas laterales y 4 macizos de 3 nichos en cada una sumando 12 en total.

- En su base tiene 3 macizos de 6 nichos cada uno.

- Geometría basada en $\boldsymbol{C R} \mathbf{1}$ y $\boldsymbol{R} \boldsymbol{R} 2$. 
Fig. 106. Traza geométrica Edificio 20.

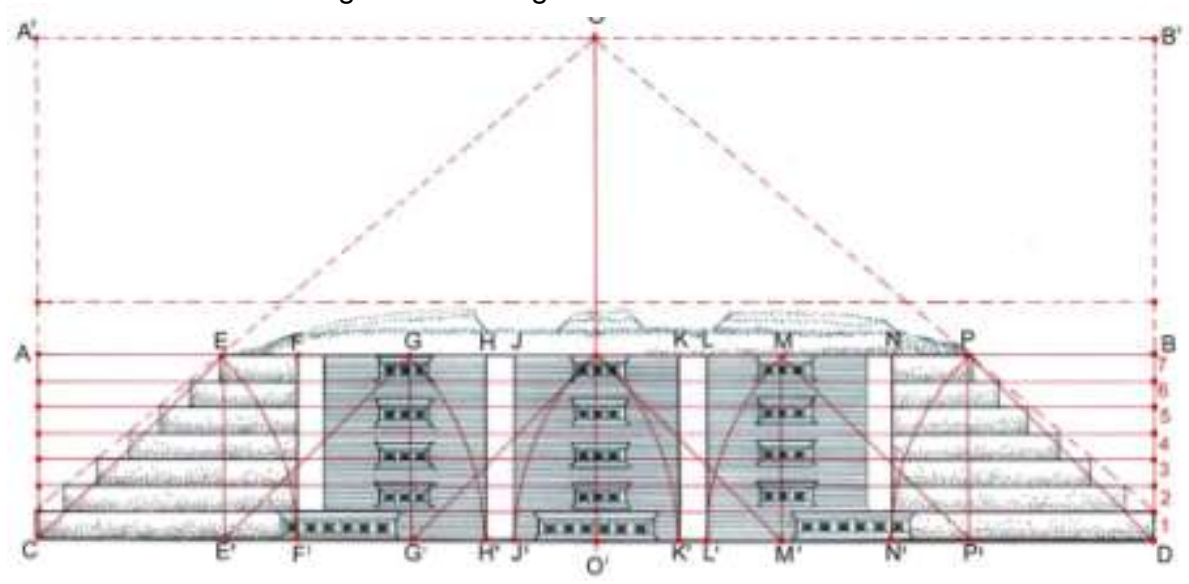

Fuente: L. Valle

ABCD: $\boldsymbol{R G}$ conformado por $6 \boldsymbol{C R} \mathbf{1}$; los abatimientos $\boldsymbol{R} \boldsymbol{R} 2$ : $\mathrm{CEF}^{\prime}, \mathrm{E}^{-} \mathrm{GH}^{\prime}, \mathrm{G}^{\prime} \mathrm{OK}^{\prime}, \mathrm{DPN}^{\prime}, \mathrm{P}^{-} \mathrm{ML}^{\prime} \mathrm{y} \mathrm{M}^{-} \mathrm{OJ}$ forman los puntos gnomónicos $\mathrm{E}, \mathrm{F}, \mathrm{G}, \mathrm{H}, \mathrm{J}, \mathrm{K}, \mathrm{L}, \mathrm{M}, \mathrm{N}, \mathrm{P}$ con sus correspondientes primas, que forman parte del diseño del edificio, muy similar al anterior; parecen iguales pero tienen variantes que los hacen muy interesantes por el juego visual que proyectan. $\mathrm{J}^{\prime} \mathrm{K}^{\prime}$ establece el ancho de la escalinata central, medida igual para las tres escalinatas que tiene el edificio. AC se divide en 7 partes iguales para obtener la altura de los 7 basamentos o cuerpos escalonados de la pirámide.

Su diseño, proporción y morfología es similar al Edificio 18, casi idéntica como espejos; su posición, enfrente de este edificio $\mathrm{y}$ por su evidente correspondencia visual $\mathrm{y}$ compositiva, establece una relación más estrecha que la que tienen los Edificios 16 y 19. 
Dadas estas características, los Edificios 18 y 20 presentan una interrelación acentuada intencionalmente por sus diseñadores, desconociendo el motivo original de ello.

\subsection{Edificios de Tajin Central.}

En esta zona, el espacio amplio, abierto y con áreas verdes alrededor, se va estrechando en una especie de laberinto interior; los edificios parecen carecer de un ordenamiento urbano aparente de acuerdo al patrón mesoamericano, como en la Plaza del Arroyo. Aquí se encuentra la Pirámide de los Nichos que, de acuerdo a las investigaciones, no tuvo un planeamiento urbanístico previo; esta se construye en un espacio limitado y estrecho, posterior a los demás edificios de El Tajin Central.

Edificio 1 o Pirámide de los Nichos. Este edificio es el más emblemático y conocido del sitio; conforma junto con los Edificios 2, 3, 4 y 5 la Plaza de la Pirámide de los Nichos. Se han tenido que llevar al cabo grandes y continuos trabajos de restauración por la fragilidad de su elaborado sistema constructivo que ha sobrevivido pese al paso del tiempo. Actualmente no se conserva el templo que existía en la parte superior, por lo que el dibujo mostrado aquí es una reconstrucción hipotética. 
- Basamento piramidal con templo superior incompleto de 17 nichos en su base: 5 en los lados norte, sur y poniente y en el frente dos56; en el interior del templo se encontraron 11 tableros con bajorrelieves escultóricos.

- Planta cuadrada de 35 X 35 m. Altura: 25 m.

- Técnica constructiva: núcleo compuesto de grandes piedras rodadas sin ningún material que las ligue entre sí. La tierra vegetal se removió antes de su construcción; la subestructura está formada por un solo cuerpo, sin descansos y construido con lajas superpuestas. 57

- Basamento de 7 cuerpos escalonados conformados por hileras de nichos con cornisa y talud disminuyendo 3 nichos por cada cuerpo desde su base: 22, 19, 16, 13, 10 y 7 sumados dan 87 multiplicado por 4 lados da un total de 348; a estos nichos se le suman los $17 \mathrm{del}$ templo superior dando un gran total de 365 nichos.

- Una escalinata en su fachada este con 2 alfardas laterales decoradas con greca escalonada y remate de nicho con cornisa; presenta también 5 macizos de 3 nichos en la parte central de la escalinata.

\footnotetext{
56 Zaleta, Leonardo, Tajín, misterio y belleza, Grupo Editorial EON, México,1991, pág. 40

${ }^{57}$ Fuente: www.naya.org.ar
} 
Fig. 107. Geometría del Edificio 1 o Pirámide de los Nichos.

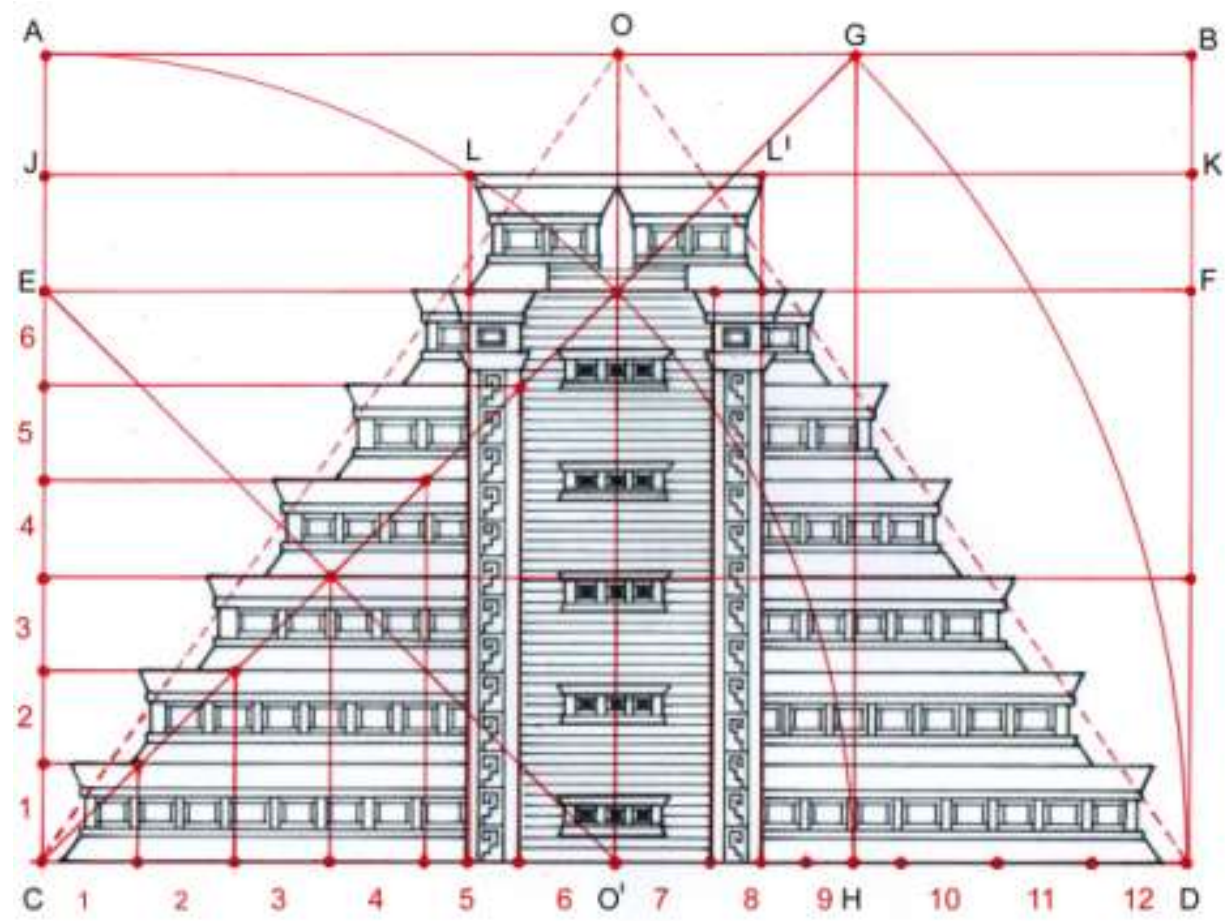

Fuente: C. Sonderenguer

AGCH: $\boldsymbol{C R 1}$ inicial/ABCD: RG: $\boldsymbol{R} \boldsymbol{R} 2$. CGD abatimiento $\boldsymbol{R} \boldsymbol{R} 2$. Abatimiento $\mathrm{AH}$ establece: el GN: O sobre la diagonal CG y tambien la altura EF compuesta por dos $\boldsymbol{C R}$ : EOCO`y OFO`D. La base dividida en 12 partes en donde 2 partes establecen ancho de escalinata y 6 partes la altura de cada basamento de la pirámide. La altura JK es hipotética.

Composición y construcción estructural de una "montaña de nichos" en el sentido metafórico, pues todos sus cuerpos están formados por hileras de nichos consecutivos que en total suman 365 (dias del año solar). La horizontalidad de sus 
líneas se interrumpe con la única escalinata central con alfardas laterales que llevan 13 grecas escalonadas en dirección vertical izquierda invertida ascendente y vertical derecha ascendente (ver Tema 5). Rematan las alfardas con cornisa y un macizo de un nicho con cornisa a la altura del último cuerpo. Los macizos centrales adosados a la escalinata se distribuyen en proporción al espacio de la misma; su nichos son de menor tamaño que los utilizados en los basamentos piramidales.

Cualidades plásticas:

Movimiento y ritmo: la percepción visual se encarga de relacionar los nichos por agrupamiento y semejanza formal, dirigiendo la visión dinámica de un lado a otro y de arriba hacia abajo rítmicamente originando la sensación del movimiento virtual.

Ligereza: al existir espacios vacíos en los nichos, lo que podría ser una gran masa constructiva, se vuelve menos "pesada"; contraste entre positivo (espacio ocupado) y negativo (espacio vacío), en relación directa con otra cualidad:

Claro-obscuro: Estas diferencias entre luz y sombra son captadas cuando entra en juego la luz solar que incide naturalmente en los nichos durante las horas del día, (como sucede similarmente en el Edificio 16 de la Plaza del Arroyo). Transparencia: Los nichos de cada esquina de cada cuerpo de la pirámide se han dejado como marcos de ventanas por donde se mira a través de ellos, capturando otras imágenes cercanas o lejanas a la pirámide. 
Fig. 108. Detalle de nicho en transparencia, Pirámide de los Nichos, Tajín.

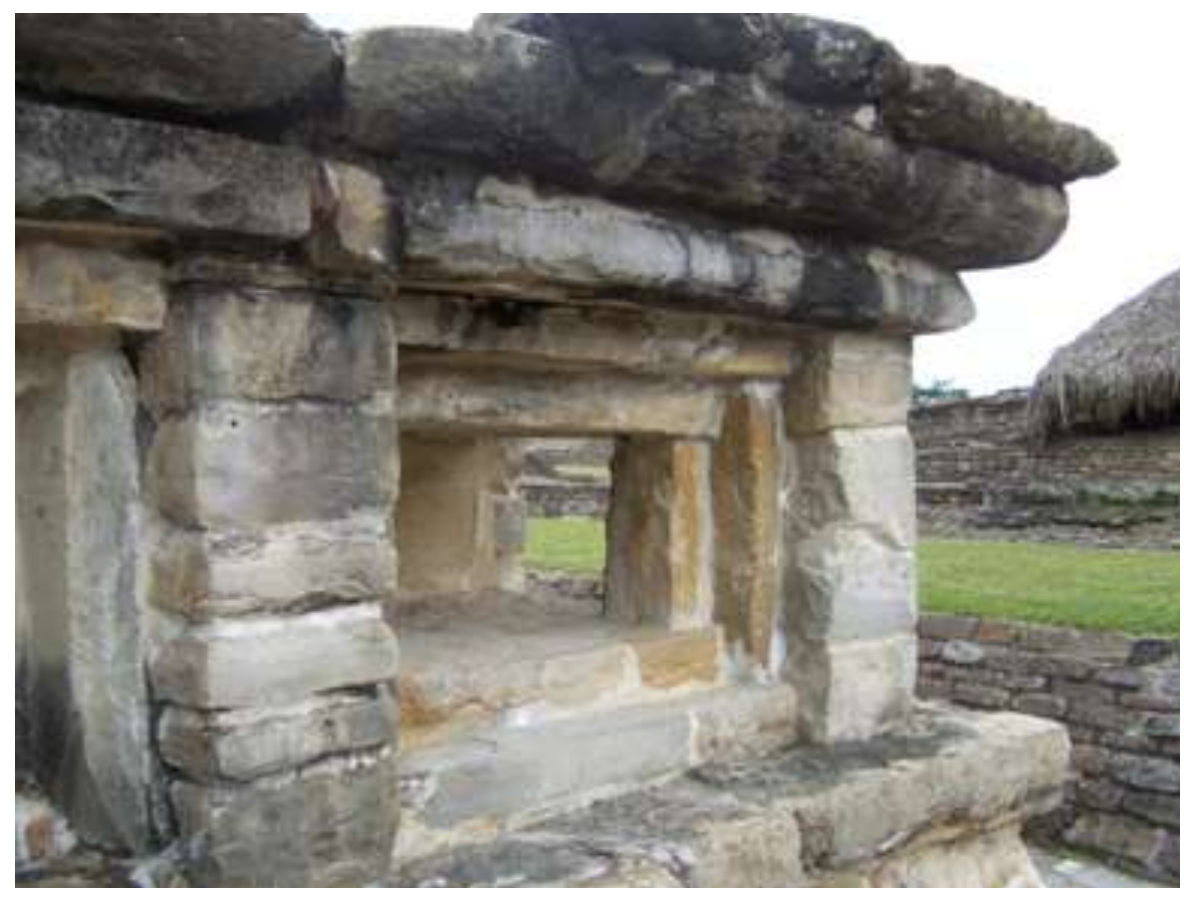

Fuente: Arqueología Mexicana.

Edificio simbólico, metafórico, astronómico, sagrado y venerado, en el que se resumen los elementos formales sobresalientes de la arquitectura-escultura de El Tajín. Su innegable magnetismo ejerce una atracción inmediata que va mas allá de su materialidad; ha trascendido al tiempo permitiendo apreciar, aún hoy en día, su estética armoniosa y equilibrada revela su pasado como centro cultural de la Costa del Golfo de México, y hoy como un sitio Patrimonio de la Humanidad. 


\section{EDIFICIO 5.}

Este edificio se encuentra asentado sobre una gran plataforma de un área de $3124 \mathrm{~m}^{2}$ que se eleva del piso $2.55 \mathrm{~m}$. Según estimaciones, había otros 4 edificios de menor tamaño en cada una de las esquinas de la plataforma, de los cuales sobrevive uno al frente. La plataforma tiene accesos en su fachada oriental y poniente. Tiene doble funcionalidad, ya que el costado sur de su plataforma forma parte de la pared lateral del Juego de Pelota Sur, uno de los más importantes por tener tableros con bajorrelieves.

En el Edificio 5 se encontró una escultura prismática del Dios Tajín, la cual permanece actualmente en la fachada; se cree que este edificio era dedicado a esta importante deidad. También se ven algunos restos de estuco rojo, probablemente de su color original.

El dibujo muestra el Edificio 5 sin la plataforma y las demás construcciones, y está basado en la copia de los planos del Proyecto Tajín. (Dibujo: L. Valle).

El edificio 5 tiene, en su fachada principal orientada al este:

- Planta rectangular

- Técnica constructiva: tuvo 5 etapas constructivas, según García Payón. Núcleo de arcilla y arena mezcladas con chapopote; se construyó sobre el piso 
geológico con cantos rodados. Recubierto con piedras labradas.

- 2 cuerpos escalonados: en el primero compuesto de talud, tablero/nichos-cornisa en hilera horizontal de 15 nichos rectangulares; en el centro tiene una ancha alfarda en cuyos extremos hay dos escalinatas con alfardas rematadas con un macizo de un nicho. E1 segundo consta de un largo talud que remata el edificio con tablero/nicho-cornisa y greca en el interior. Tiene una escalinata central sobre el talud con alfardas laterales rematadas con un macizo de un nicho y dos grecas en el interior.

Fig. 109. Traza geométrica del Edificio 5.

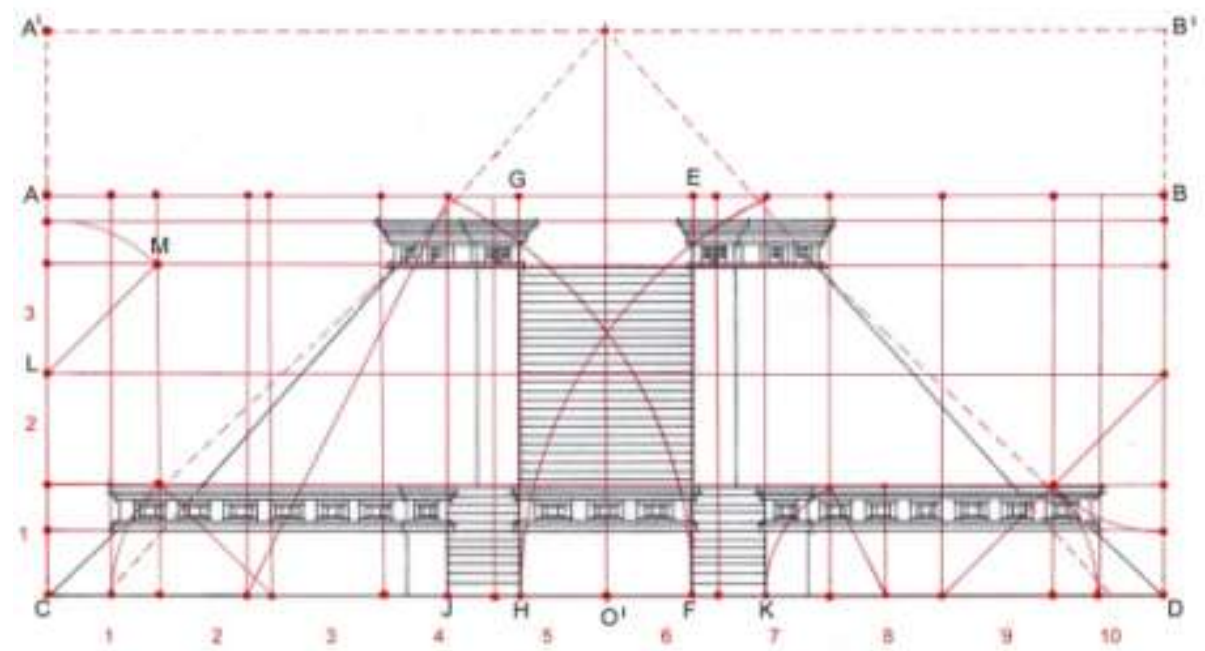

Fuente: L. Valle 
ABCD: $\boldsymbol{R} \boldsymbol{G}$ compuesto de dos $\boldsymbol{R A}$ traslapados: AECF y GBHD en donde $\mathrm{HF}$ corresponde al ancho de la escalinata central y $\mathrm{JH} / \mathrm{FK}$ ancho de las dos escalinatas inferiores. Abatimiento RR2: LMA altura máxima del edificio. La base dividida en 10 partes: una parte establece la altura del basamento inferior y 3 partes establecen la altura de la escalinata principal y gran talud que conforma el cuerpo de la pirámide.

Este edificio refleja en su composición cambios significativos en las proporciones del talud (a como se venía utilizando en la Fase I), que dan como resultado innovaciones modernistas y atrevidas en el diseño final; es uno de los edificios mas atractivos por su sobriedad: mínimo de elementos formales, dinamismo en la acentuada inclinación ascendente del talud, lineas verticales $\mathrm{y}$ oblicuas que prevalecen en equilibrio $\mathrm{y}$ armonía. La ausencia del empleo de los macizos en la escalinata representa una variación al diseño anterior así como el remate superior de los nichos con cornisa. No tiene templo superior.

\section{EDIFICIO 3.}

Situado enfrente de la Pirámide de los Nichos y cerrando el espacio de la plaza del mismo nombre, su fachada principal se encuentra orientada hacia el sur. Colindando muy estrechamente con este edificio se encuentra el Edificio 23 que 
presenta igualmente planta cuadrada y proporciones similares al Edificio 3, pareciendo edificios gemelos.

Durante las exploraciones, los arqueólogos observaron restos de derrumbes causados, aparentemente, por un terremoto. La parte superior derecha del edificio no está; el siguiente dibujo es copia del plano que se realizara durante el Proyecto Tajín. Sus características son:

- Planta cuadrada de $34 \mathrm{~m}$ por lado. ${ }^{58}$

- Consta de 7 cuerpos escalonados con elementos formales rectangulares denominados cuadretes de 40 cm de largo.

- Escalinata central con alfardas laterales rematadas en un macizo de un nicho. La escalinata tiene en su parte central 6 macizos intercalados de 3 nichos.

Fig. 110. Reconstrucción del Edificio 3, Tajín Central

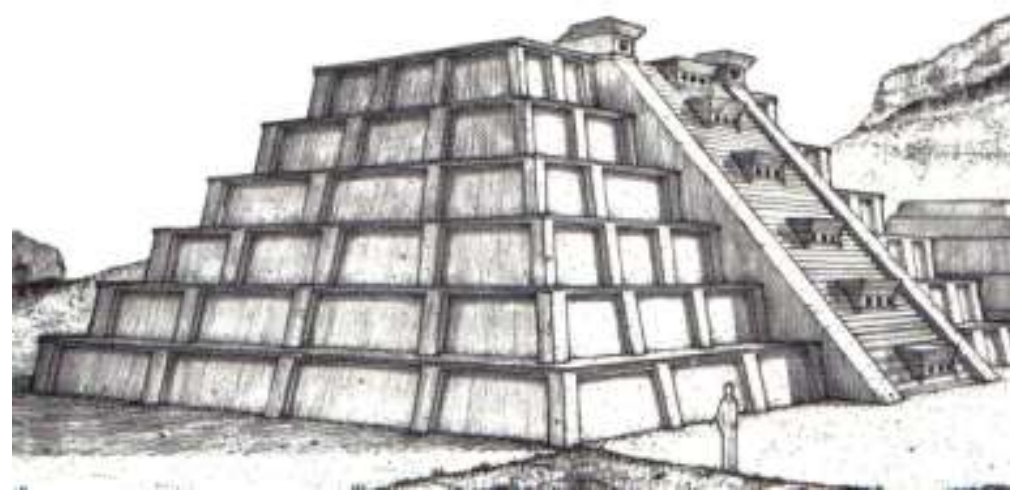

Fuente: Arte prehispánico en Mesoamérica. P. Gendrop

\footnotetext{
${ }^{58}$ García Payón, J., Guía Oficial del Tajín, INAH, México, 1976, pág. 24.
} 
Fig. 111. Geometría del Edificio 3.

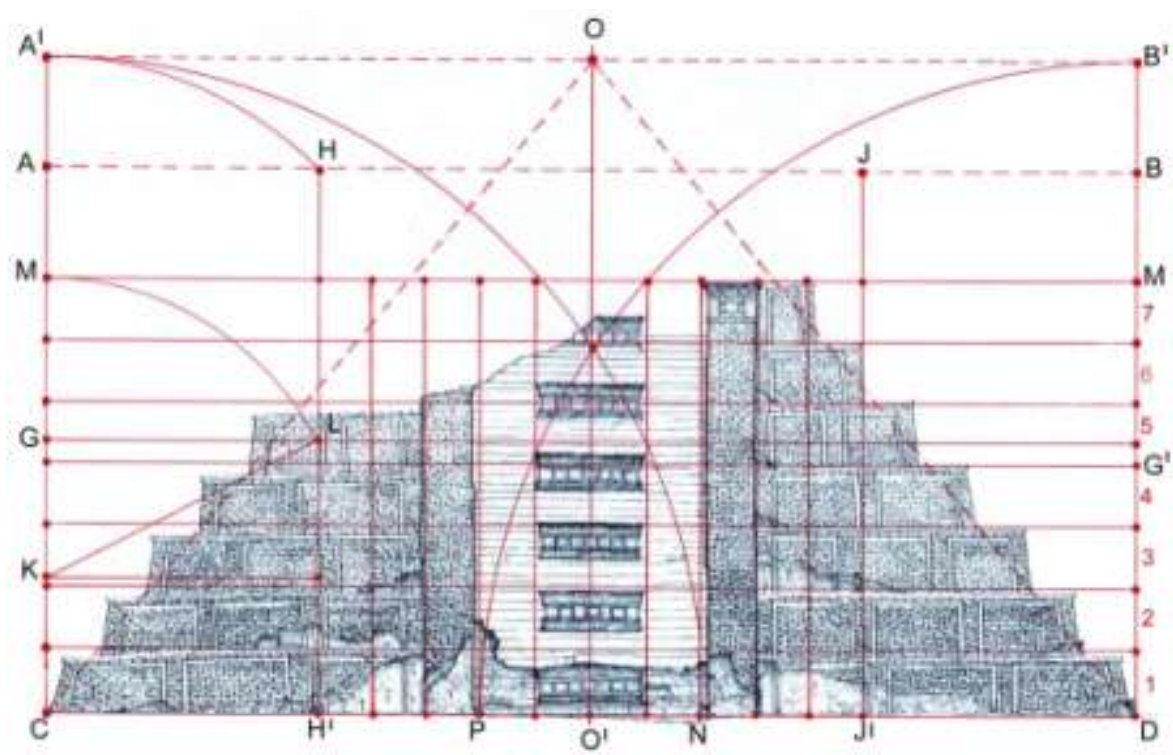

Fuente: L. Valle

ABCD: RG compuesto de dos CR1. Abatimientos RR2: GHE establece el rectángulo $\mathrm{A}^{\prime} \mathrm{B}^{\prime} \mathrm{CD}$ y diagonales virtuales $\mathrm{CO}$ y DO: Abatimiento RA: KLM establece la altura de los 7 basamentos del edificio.

Es uno de los pocos edificios con proporciones similares al 23 y a la Pirámide de los Nichos por su planta cuadrada. Presenta, en todos sus cuerpos, elementos de forma rectangular o cuadrada, que parecen grandes recuadros o paneles arremetidos en secuencia horizontal y vertical. Este recurso formal también se observa en algunas pirámides mayas, pero en relieve, por ejemplo, en la Pirámide de Chichén Itzá. 
Fig. 112. Pirámide de Chichén Itzá. Ejemplo del uso de paneles en los cuerpos de la pirámide.

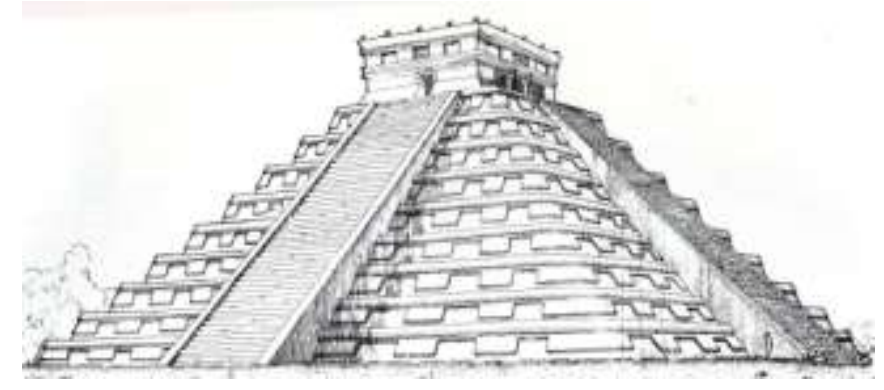

Fuente: Arte prehispánico en Mesoamérica. P. Gendrop

Al parecer su color original era el azul turquesa, pues se puede apreciar in situ, en algunas partes de su superficie, restos del estuco policromado de azul turquesa que recubría cada cuerpo de esta pirámide.

\subsection{EDIFICIOS DE TAJIN CHICO}

Para acceder a esta zona se tiene que ascender por un largo muro de contención realizado para tales fines, es decir, los de marcar límites y restringir el acceso a una serie de edificaciones de tipo residencial que cuentan con habitaciones y ventanas, techos colados sin varillas, dos pisos o niveles de construcción, túneles subterráneos que comunican con otros edificios y el Edificio de las Pinturas (uno de los pocos ejemplos de la pintura mural realizada en El Tajin). Se ha reconocido en otros trabajos que las edificaciones en El Tajín 
Chico tienen, en sus fachadas, abundantes grecas escalonadas con variantes formales innovadoras, a diferencia de la zona central; hay una constante de utilizar otros elementos formales en el diseño, como por ejemplo los rombos entrecruzados del Edificio D. Todos son de estilo geométrico-abstracto $\mathrm{y}$ connotaciones simbólicas. Los nichos nunca dejaron de utilizarse en ninguna Fase cronológica. Los del Tajin Chico pertenecen a la Fase II.

\section{EDIFICIO A.}

Se encuentra sobre una terraza artificial y es el primero de un conjunto de edificios de carácter residencial, que forman entre sí una pequeña plaza: el A, B y C. En el estado actual del edificio se puede ver sólo el cuerpo de la base; sin embargo, el Arquitecto García Payón realiza la reconstrucción del edificio en sus planos de la fachada, planta y detalles escultóricos. Es uno de los edificios que llama la atención por su elaborado diseño, complejidad y el uso abundante en la fachada de la greca escalonada, dispuesta en versiones formales diferentes en repetición, que cubren tanto exteriores como interiores. Cuenta con diversas habitaciones que se dividen en 2 grupos: las del primero se encuentran alrededor, dos en cada esquina; como dato importante, los cuartos de las esquinas noreste y noroeste tenian anchos ventanales. Las habitaciones del segundo grupo se hallan sobre una pirámide rectangular 
truncada que ocupa el centro del edificio y en un nivel más alto.

- Palacio residencial de $750 \mathrm{~m}^{2}$

- Planta rectangular de 35 X $22 \mathrm{~m}$.

- Se observan tres niveles de construcción: el primero tiene un pequeño talud y cornisa, seguido de un gran tablero compuesto de paneles rectangulares de gran formato (tres por lado); en el centro muestra escalinatas con alfardas laterales que llevan grecas escalonadas en vertical derecha e izquierda ascendentes. La escalinata tiene, a su vez, otra escalinata central en profundidad hacia el patio interior, techada con dos planos inclinados, dando la apariencia de un arco tipo maya (único ejemplo de su uso en El Tajín). El tablero descrito, además, tiene, en su parte superior, una hilera de grecas escalonadas en orden horizontal, rematadas con cornisa.

- El segundo nivel empieza con un pequeño talud seguido de un alto tablero dividido en dos secciones horizontales: una sección está compuesta por una hilera de grecas escalonadas en simetría radial y la otra sección, de mayor proporción, tiene como motivo ganchos de greca (sin escalones), dispuestos en simetría especular y en grupos de tres pares en secuencia vertical. 
Fig. 113. Reconstrucción de García Payón en perspectiva del Edificio A.

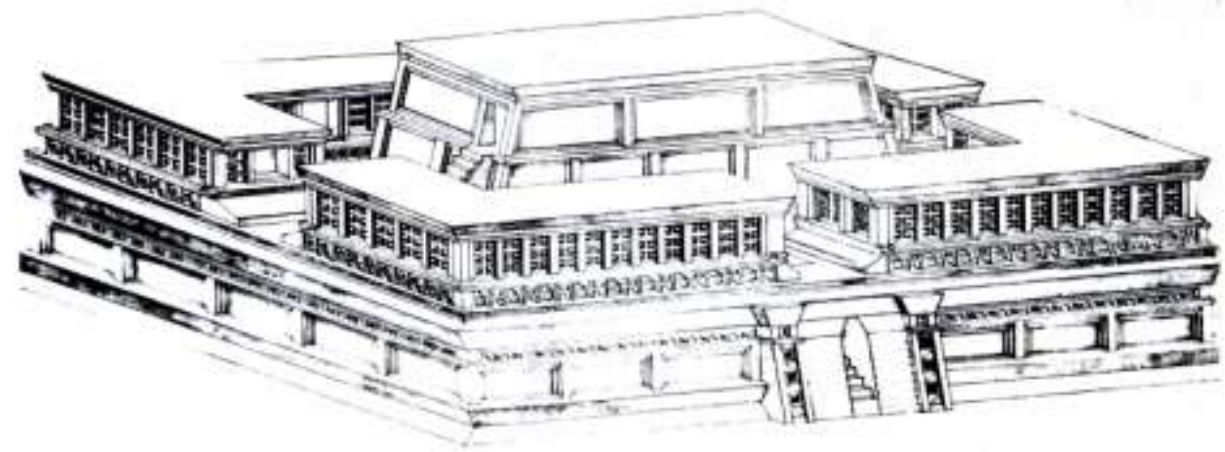

Fuente: Guía Oficial de El Tajín.

Fig. 114. Detalles escultóricos del Edificio A. Grecas segundo nivel.

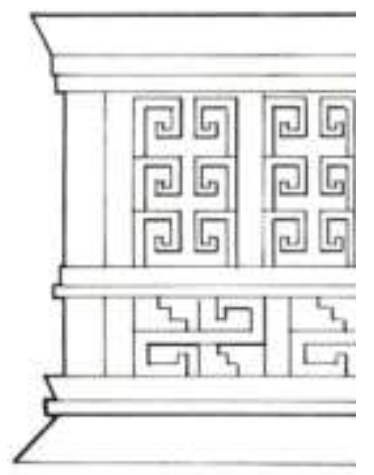

Fuente: I. Marquina.
Fig. 115. Arco tipo maya en El Tajín.

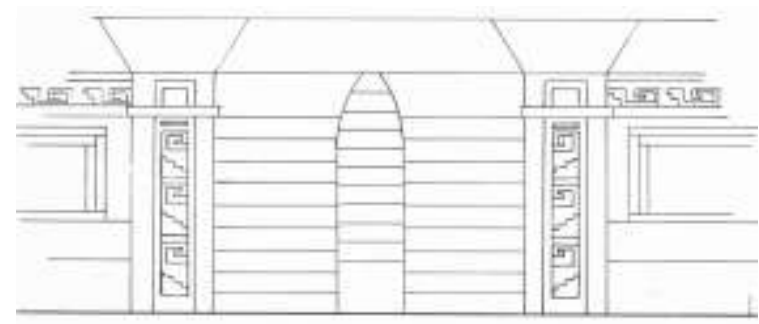

Fuente: G. Payón e I. Marquina.

- El tercer nivel (el de mayor altura), que se observa en la fachada, corresponde a una estructura interior (la pirámide rectangular) que sobresale del centro de todo 
el edificio. Tiene tres grandes paneles rectangulares rematados con cornisa. Sus muros muestran una ligera inclinación. Los techos eran planos y de una sola losa; el edificio estuvo decorado con pinturas de distintos colores que mostraban escenas de la vida cotidiana. 59

Fig. 116. Geometría del Edificio A.

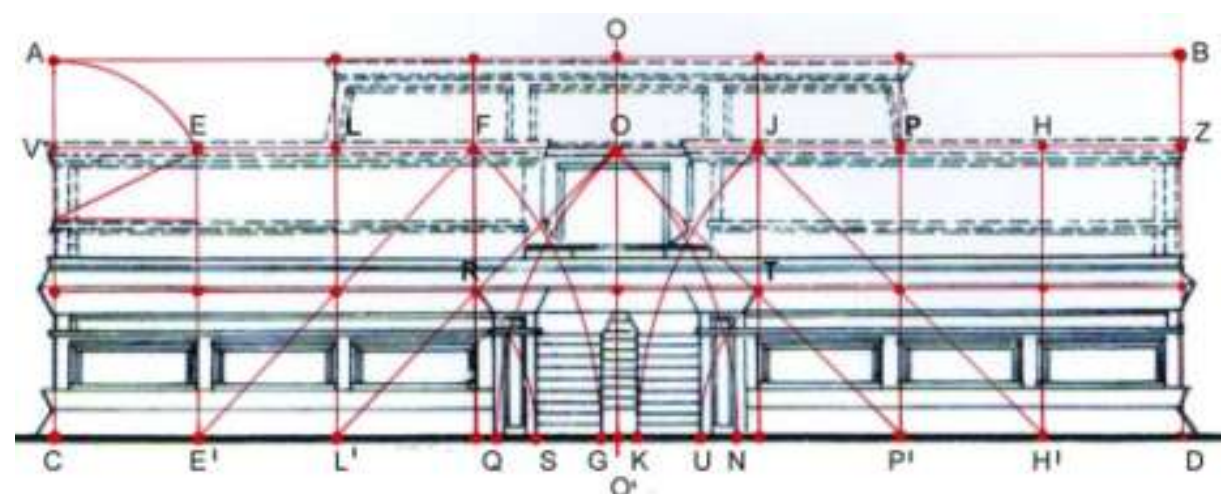

Fuente: L. Valle

(Reconstrucción del Arq. García Payón; la línea continua marca lo que queda del edificio actualmente). RG: ABCD: compuesto de 4 CR1: VLCL', LOL'O', OPO`P' y PZP`D. Abatimientos RR2: EFG/HJK establecen ancho de arco tipo maya. Abatimientos $\boldsymbol{R} \boldsymbol{R} 2$ : LMN y PMQ ancho de entrada con alfardas. Abatimientos RR2: LRS y PTU establecen ancho de escalinata principal. Abatimiento RA: VEA establece altura hipotética del edificio.

${ }^{59}$ García Payón, J., Guía Oficial del Tajín, INAH, México, 1976. 
Este es uno de los edificios mas elaborados y único en su género, pues está completamente cubierto de detalles escultóricos: grecas con diversas variantes, algunas no utilizadas antes, como la greca en simetría radial, simulando una swástica en movimiento, nichos-cornisas, grandes paneles, escalinata con arco tipo maya en su fachada. En su estado original debió tener una jerarquía significativa, su diseño así lo demuestra. Además de sus variados elementos formales, la arquitectura de este es poco común: tiene un pasillo interior que rodea la construcción central de $3 \mathrm{~m}$ de altura.

Fig. 117. Estado actual del Edificio A, Tajín Chico.

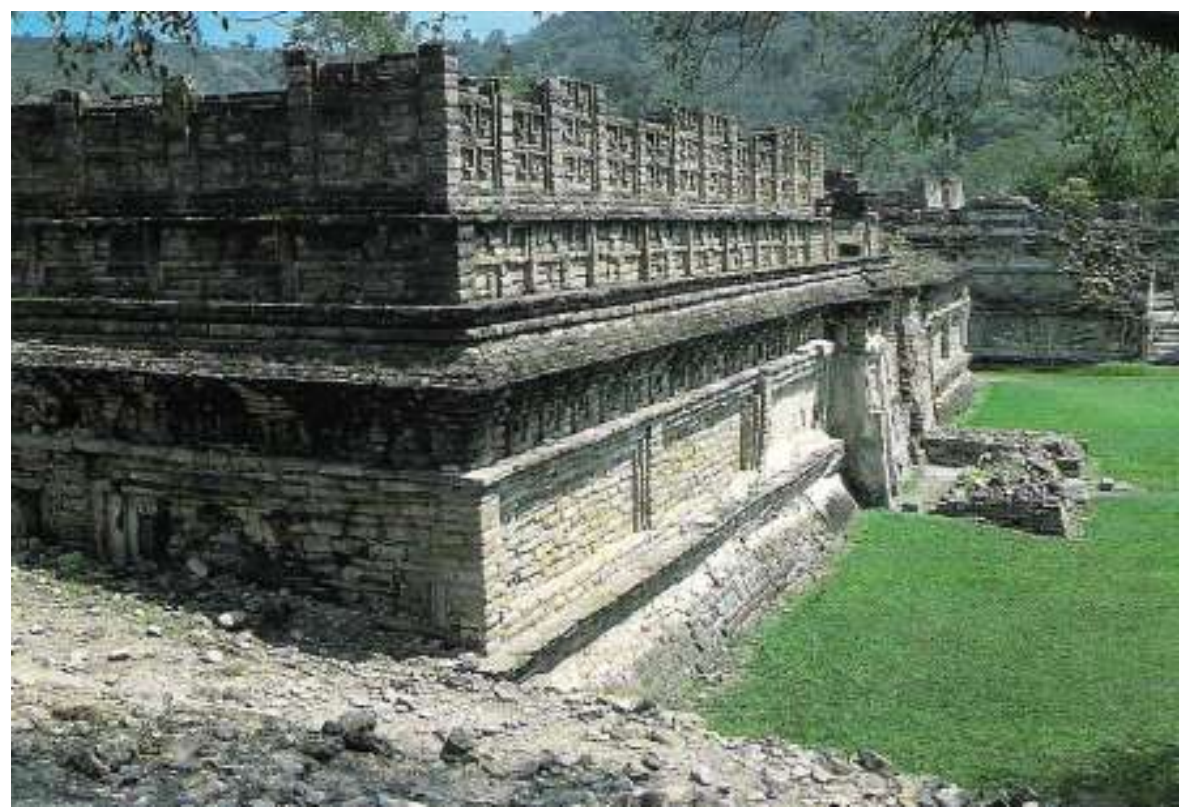

Fuente: Guías Arqueológicas Tajín. 


\section{EDIFICIO C.}

Actualmente, sólo se ve el basamento de este edificio en forma de pirámide, pues la parte superior está en ruinas. Se encuentra colindante con el Edificio $\mathrm{B}$, y juntos hacen escuadra con el Edificio A.

Cuenta con dos fachadas: una al poniente, hacia la plaza y otra hacia el oriente.

El dibujo siguiente muestra la fachada oriental, tomada de copia de planos realizados durante el Proyecto Tajín.

- Planta rectangular de 60 X $37 \mathrm{~m}$

- Se aprecia un basamento piramidal de 3 cuerpos: 2 completos y uno incompleto. Los dos primeros están compuestos de talud, tablero/nicho-cornisa con greca escalonada, dispuestos en hileras horizontales (el primero tiene el talud más pronunciado que el segundo). El tercer cuerpo tiene talud y cornisa, siendo de menor altura que los anteriores; sobre este se levantaban muros verticales donde estaban las habitaciones. Según García Payón, los muros tenían grandes tableros divididos entre sí por pilastras y molduras, y en cada uno de ellos había pinturas murales con escenas rituales.

- Amplia escalinata central con alfardas laterales, con dos remates de un macizo de un nicho, con 2 grecas interiores dispuestas en simetría axial. En el centro de la escalinata hay dispuestos tres macizos de 5 nichos 
rectangulares con grecas en simetria especular exceptuando el nicho central.

Fig. 118. Geometría del Edificio C.

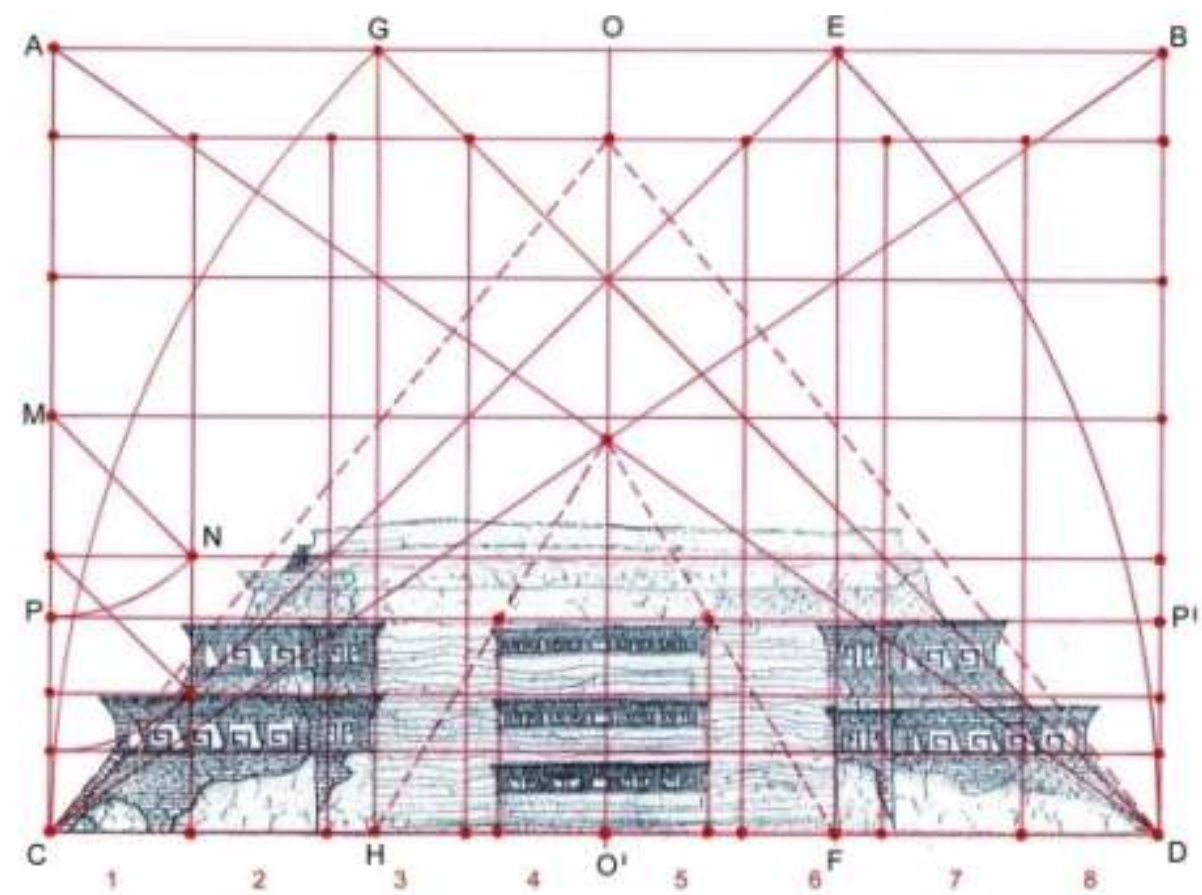

Fuente: L. Valle

AECF: $\boldsymbol{R} \mathbf{R}$ inicial. ABCD: $\boldsymbol{R}$ : $\boldsymbol{R} \boldsymbol{R} \mathbf{2}$. CED abatimiento $\boldsymbol{R} \boldsymbol{R} \mathbf{2}$. Invertimos el abatimiento del lado izquierdo con DGC y se establece HF ancho de escalinata central. Abatimiento RR2: MNP produce altura del segundo basamento. 
Fig. 119. Grecas escalonadas en secuencia dirección horizontal Edificio C, Tajín Chico.

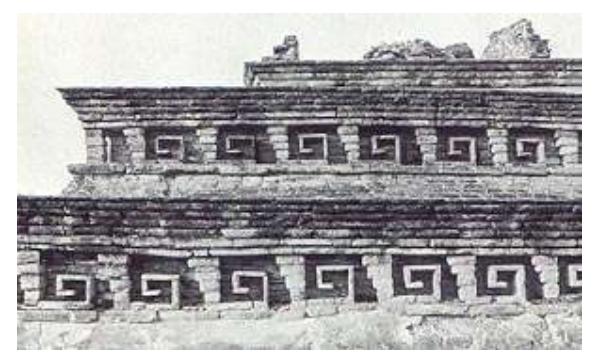

Fuente: Paul Gendrop.

Este edificio destaca por el uso de la greca escalonada en los cuerpos del basamento (parecen nichos con greca interior, pero en realidad son sólo grecas ingeniosamente trabajadas con piedras laja) marcando una dirección visual horizontal derecha invertida (ver Tema 5), y así, también provoca un efecto dinámico: primero hacia el interior de la greca por su propia naturaleza geométrica (recordando que en sí misma representa a la estilización un caracol cortado) y, posteriormente, siguiendo la linea horizontal de cada cuerpo escalonado. Un cambio en el diseño de los macizos centrales se obsreva al colocar un nicho vacío en el centro, y los nichos siguientes con greca escalonada en simetría axial, con dirección central.

Fig. 120. Macizo central, Edificio 3.

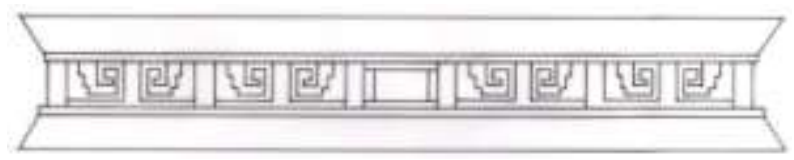

Fuente: L. Valle 


\subsection{COMPLEJO DE LAS COLUMNAS, EDIFICIO 42.}

Se encuentra en el nivel superior del asentamiento y es el edificio más importante del sitio. Desde ahí se domina la vista de toda la zona arqueológica.

En realidad se trata de una gran plataforma rectangular, que según los estudios de García Payón mediría unos 196 m de longitud X $90 \mathrm{~m}$ de anchura y $24 \mathrm{~m}$ de altura. Tenía acceso por dos escalinatas: la principal al oriente y otra al poniente.

Sobre esta gran plataforma artificial se asienta el conocido como Edificio 42, cuya fachada está orientada al este con un longitud de $18 \mathrm{~m}$; conecta al sur con otras estructuras. Esta es la que tomará para el análisis, aunque gran parte de la misma se encuentre en ruinas; el dibujo mostrado es la reconstrucción de García Payón.

A este edificio se le conoce como el Edificio de las Columnas porque se encontraron al pie del mismo varios tambores de piedra que estarían superpuestos a manera de columnas en el pórtico y sostenían un techo abovedado; dichas estructuras cilíndricas están ricamente labradas con bajorrelieves que representan escenas del personaje conocido como 13 Conejo, último gobernante del sitio.

Características:

- Palacio residencial de planta rectangular, que forma parte de una plaza interior, y rodeado de estructuras.

- La fachada está compuesta de cuatro cuerpos con talud, tablero/nichos-cornisa con grecas escalonadas en el interior. Una amplia escalinata con alfardas parte 
de la base del edificio hasta el tercer cuerpo y se estrecha en el último nivel. En este cuerpo superior hay 6 grandes paneles o tableros (que tenían pintura mural) con diseño de cruz escalonada en bajorrelieve, tres por cada lado de las alfardas de la escalinata central, que está también con motivos geométricos en secuencia ascendente para rematar con un macizo de un nicho y cornisa. En la parte superior de estos paneles corre una hilera de nichos con cornisa. El edificio continuaría con otros niveles que ya no es posible adivinar, por el estado de destrucción en que se encuentra actualmente.

Fig. 121. Geometría del Edificio de las Columnas. Reconstrucción hipotética de García Payón.

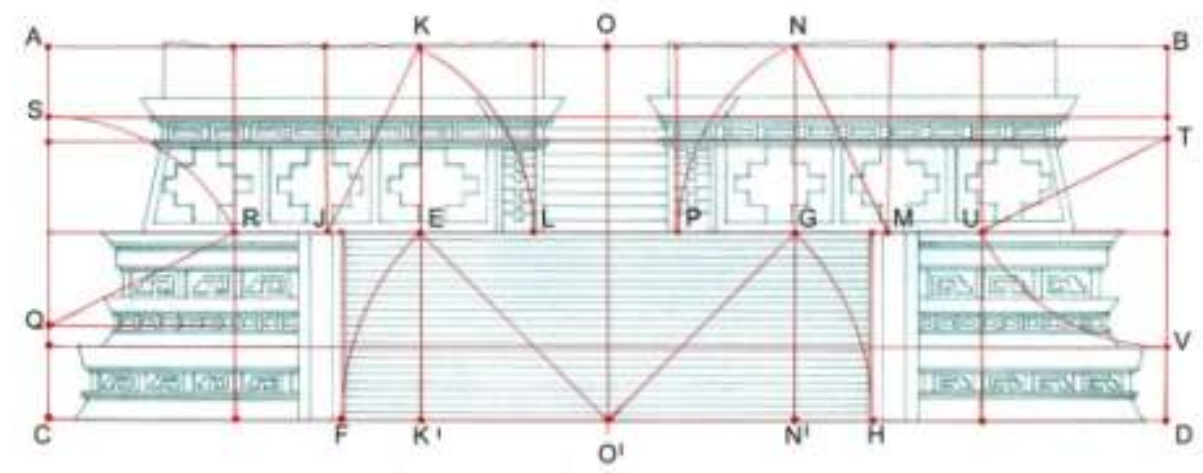

Fuente: L. Valle

ABCD:RG: tres CR1 iniciales: AKCK', $\mathrm{KK}^{`} \mathrm{NN}^{-}$, y $\mathrm{NBN}^{`} \mathrm{D}$. Abatimientos RR2: O`EF Y O`GH establecen el ancho de la escalinata central mayor. Abatimientos RA: JKL y MNP es el ancho de la escalinata superior menor. Abatimiento RA: QRS 
establece la altura superior sin cornisa. Abatimiento $\boldsymbol{R A}$ : TUV es la altura del primer basamento del edificio.

Tomando como guía este dibujo de una reconstrucción, se puede decer que en este edificio, como en el Edificio A, también se utilizaron elementos formales diferentes, como por ejemplo, las grandes cruces geométricas sobre los paneles del cuerpo superior, que en el Tema 5 se nombró como cruz chacana. Esta dispuesta en simetría lateral; su proporción respecto a los demás elementos indica que se quería destacar en importancia visual; pudiera ser el objetivo también, el apreciarse a la distancia. La cruz representa simbólicamente, entre otras cosas: el axis mundi, los 4 rumbos del universo mas un quinto punto que los une y equilibra (el quincunce); el arriba y abajo equilibra al par de opuestos Norte-Sur/EsteOeste.

Con respecto al diseño formal de las alfardas, se ha relacionado con la estilización de las vértebras de una columna vertebral; estan dispuestas en secuencia vertical ascendente siguiendo la dirección de la escalinata.

La greca escalonada sigue presente en esta fase urbana (Fase III) en los nichos de los cuerpos del Edificio de las Columnas en dirección central. 
Fig. 122. Edificio de las Columnas

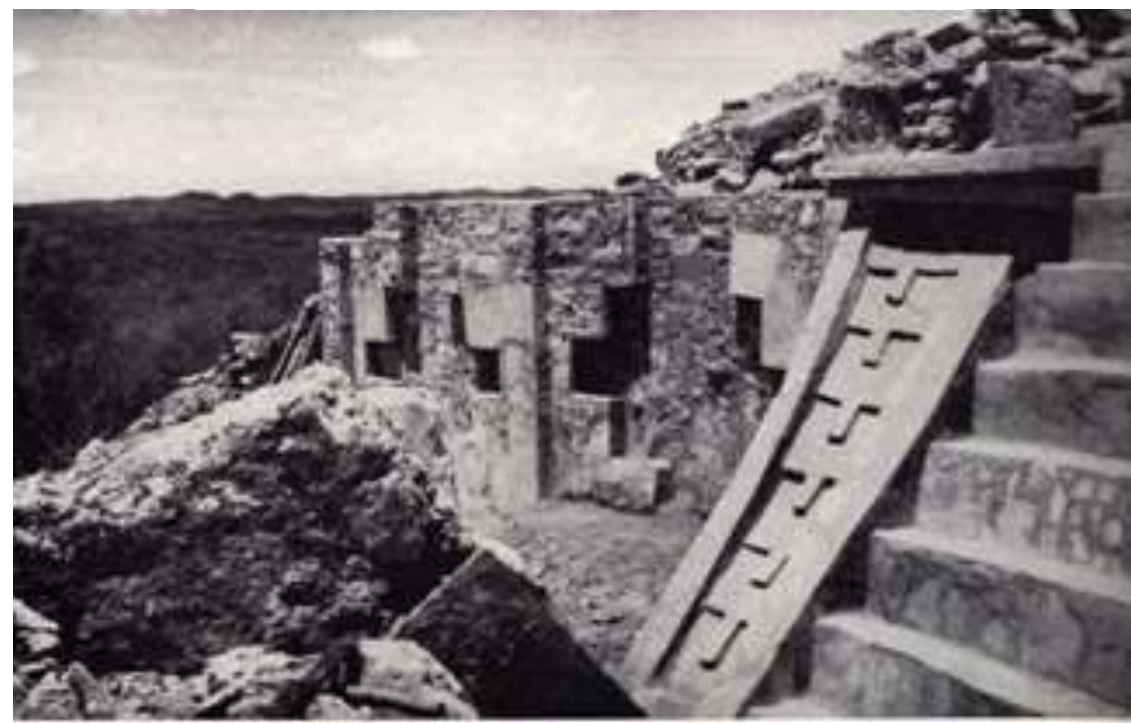

Fuente: García Payón en la Guía Oficial de El Tajín.

\section{OBSERVACIONES GENERALES:}

Edificios de la Plaza del Arroyo: Las constantes formales que prevalecen son:

- Uso de macizos de nichos en las escalinatas centrales de las fachadas principales en grupos de 3, 4, 6, 7 y hasta 8 nichos.

- Uso de cuerpos escalonados que van de 5, 7 y 18.

- E1 RR2 es la proporción geométrica presente en los 4 edificios; también se utilizó en algunos casos, CR1, $R \boldsymbol{A}$ y $\boldsymbol{R} \boldsymbol{R} 3$. 
- Organización dentro espacio urbano de acuerdo al esquema típico mesoamericano orientado con los 4 puntos cardinales.

Edificios de Tajín Central:

- Uso de macizos centrales en las escalinatas principales de los edificios.

- Variantes de diseño en la proporción del taludtablero/nicho-cornisa.

- Uso de cuerpos escalonados de 2 y 7.

- Introducción de nuevos elementos formales en los edificios por ejemplo, la greca escalonada.

- Se utiliza la alfarda para colocar elementos formales; anteriormente no se le dio esa utilidad.

- La proporción $\boldsymbol{R} \boldsymbol{R} 2$ es constante; también se usó $\boldsymbol{C R} \mathbf{1} y$ $\boldsymbol{R A}$.

Edificios de Tajín Chico y Columnas:

- Uso intensivo de la greca escalonada con diversidad de variantes formales en las fachadas de los edificios.

- La técnica visual predominante es la secuencia de repetición de unidades modulares sobre los cuerpos de los edificios provocando la sensación visual de movimiento en dirección horizontal principalmente.

- Construcción de muros verticales, techos colados y ventanas. 
- Varios niveles de altura sobre plataformas, construidas artificialmente.

- Se usó $\boldsymbol{R} \boldsymbol{R} 2, \boldsymbol{C R} \mathbf{1}$ y $\boldsymbol{R A}$ en los tres edificios caso de estudio.

La importancia formal de los nichos en la arquitecturaescultura:

E1 nicho/cornisa volada es un elemento constante en los edificios durante todas las fases de desarrollo. Representa la unidad formal y estructural del lenguaje visual, pues ya no puede descomponerse en otras partes; en el sentido de la Semiótica, representa la mínima unidad sígnica o lexema. 60 El nicho representa el elemento identificador de la estética desarrollada en El Tajín y la esencia de su arquitectura; marca la pauta a seguir dentro de un universo de combinaciones plásticas cuyo resultado es su protagonismo visual en todas las áreas urbanas de la ciudad.

Es por ello la aportación formal más importante que desafia toda lógica constructiva, considerando su temporalidad histórica; su propuesta es la contrariedad a las leyes de la gravedad con la cornisa superior, denotando la audacia y modernidad de sus constructores. Aporta a los edificios el dinamismo propio del movimiento ascendente-descendente en equilibrada armonía. La iluminación, que incide naturalmente sobre los nichos, contribuye a acentuar esta movilidad visual,

${ }^{60}$ Consultar el apartado 8.1 del Tema 8 de esta tesis. 
siendo el contraste claro-obscuro la consecuencia de su diseño estructural.

Dentro del ámbito interpretativo (iconología) los nichos siguen siendo un enigma. Su propósito y función simbólica permanece codificado dentro de un sistema que aún se ignora. Si bien, se tienen algunas evidencias, como por ejemplo, la utilidad calendárica en la Pirámide de los Nichos.

Se cree también que los nichos servian para la quema del copal (especie de incienso), costumbre ampliamente utilizada en los templos. Los actuales totonacos se refieren al lugar sagrado de Tajín como "lugar de humaredas", debido a esta actividad ritual. ${ }^{61}$

Sin duda, los nichos abren caminos para la investigación multidisciplinar; su importancia radica, también, por ser el legado de la cultura del Tajín para el mundo como patrimonio cultural de la Humanidad.

A continuación se muestran las tablas-resumen de las constantes formales y compositivas de los Edificios Casos de Estudio:

61 Westheim, P., Ideas fundamentales del arte prehispánico en México, Alianza Editorial Era, México, 1972, pag. 280. 
TABLA DE CONSTANTES FORMALES EN FACHADAS PRINCIPALES

EDIFICIOS DE LA PLAZA DEL ARROYO

\begin{tabular}{|c|c|c|c|c|}
\hline & EDIF. 16 & EDIF. 18 & EDIF. 19 & $\begin{array}{l}\text { EDIF. } \\
20\end{array}$ \\
\hline CUERPOS ESCALONADOS & & $\begin{array}{c}\boldsymbol{V} \\
7 \text { cuerpos }\end{array}$ & $\begin{array}{c}\mathscr{V} \\
18 \text { cuerpos }\end{array}$ & $\begin{array}{l}\quad \boldsymbol{V} \\
7 \\
\text { cuerpos }\end{array}$ \\
\hline $\begin{array}{l}\text { CUERPOS ESCALONADOS } \\
\text { CON TALUD- } \\
\text { TABLERO/NICHOS/CORNI } \\
\text { SA VOLADA }\end{array}$ & $\begin{array}{c}\checkmark \\
5 \text { cuerpos }\end{array}$ & & & \\
\hline $\begin{array}{l}\text { ESCALINATAS CON } \\
\text { ALFARDAS }\end{array}$ & & $\begin{array}{l}\quad \checkmark \\
3 \\
\text { escalinatas }\end{array}$ & $\underset{1 \text { escalinata }}{\checkmark}$ & $\begin{array}{l}\quad \checkmark \\
3 \\
\text { escalina } \\
\text { tas }\end{array}$ \\
\hline $\begin{array}{l}\text { ESCALINATAS Y ALFARDA } \\
\text { CON REMATE SUPERIOR }\end{array}$ & $\begin{array}{c}\checkmark \\
\text { dobles }\end{array}$ & & & \\
\hline $\begin{array}{l}\text { MACIZOS DE NICHOS EN } \\
\text { ESCALINATAS }\end{array}$ & & $\begin{array}{c}\boldsymbol{V} \\
\text { En grupos } \\
\text { de } 3 \text { y de } 7\end{array}$ & $\begin{array}{l}\quad \\
\text { En grupos } \\
\text { de } 7\end{array}$ & $\begin{array}{l}\quad \checkmark \\
\text { En } \\
\text { grupos } \\
\text { de } 3 \text { y de } \\
6\end{array}$ \\
\hline $\begin{array}{l}\text { MACIZOS DE NICHOS EN } \\
\text { ALFARDAS }\end{array}$ & $\begin{array}{c}\qquad \\
\text { En grupos } \\
\text { de } 4\end{array}$ & & & \\
\hline TEMPLOS SUPERIORES & 2 templos & $\begin{array}{l}\boldsymbol{V} \\
3 \text { templos }\end{array}$ & 1 templo & $\begin{array}{l}\quad \\
3 \\
\text { templos }\end{array}$ \\
\hline PLANTA CUADRADA & & & $\checkmark$ & \\
\hline PLANTA RECTANGULAR & $\checkmark$ & $\checkmark$ & & $\checkmark$ \\
\hline $\begin{array}{l}\text { USO DE GRECA } \\
\text { ESCALONADA }\end{array}$ & & & & \\
\hline
\end{tabular}


TABLA DE CONSTANTES FORMALES EN FACHADAS

PRINCIPALES

EDIFICIOS DE TAJIN CENTRAL

\begin{tabular}{|c|c|c|c|}
\hline & $\begin{array}{l}\text { PIRÁMTDE } \\
\text { DE LOS } \\
\text { NICHOS }\end{array}$ & $\begin{array}{c}\text { EDIFICIO } \\
3\end{array}$ & EDIFICIO 5 \\
\hline CUERPOS ESCALONADOS & & $\begin{array}{c}\boldsymbol{V} \\
7 \text { cuerpos }\end{array}$ & \\
\hline $\begin{array}{l}\text { CUERPOS ESCALONADOS } \\
\text { CON TALUD- } \\
\text { TABLERO/NICHOS/CORN } \\
\text { ISA VOLADA }\end{array}$ & $\begin{array}{c}\checkmark \\
7 \text { cuerpos }\end{array}$ & & $\underset{2 \text { cuerpos }}{\mathscr{V}}$ \\
\hline $\begin{array}{l}\text { ESCALINATAS CON } \\
\text { ALFARDAS }\end{array}$ & $\begin{array}{c}\mathscr{V} \\
1 \text { escalinata }\end{array}$ & $\begin{array}{c}\mathscr{V} \\
1 \text { escalinata }\end{array}$ & $\underset{1}{\mathscr{V}}$ \\
\hline $\begin{array}{l}\text { ESCALINATAS Y } \\
\text { ALFARDA CON REMATE } \\
\text { SUPERIOR }\end{array}$ & & & \\
\hline $\begin{array}{l}\text { MACIZOS DE NICHOS EN } \\
\text { ESCALINATAS }\end{array}$ & 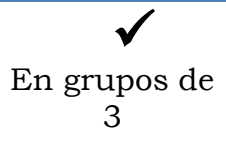 & $\underset{3}{\mathscr{V}} \underset{3}{\text { En grupos de }}$ & \\
\hline $\begin{array}{l}\text { MACIZOS DE NICHOS EN } \\
\text { ALFARDAS }\end{array}$ & & & $\begin{array}{c}\qquad \\
\text { En grupo de } 3\end{array}$ \\
\hline TEMPLOS SUPERIORES & 1 templo & & \\
\hline PLANTA CUADRADA & $\checkmark$ & $\checkmark$ & \\
\hline PLANTA RECTANGULAR & & & $\checkmark$ \\
\hline $\begin{array}{l}\text { USO DE GRECA } \\
\text { ESCALONADA }\end{array}$ & $\underset{\text { En alfardas }}{\checkmark}$ & & $\begin{array}{c}\checkmark \\
\text { Gancho de } \\
\text { greca en } \\
\text { simetría axial } \\
\text { en nichos }\end{array}$ \\
\hline
\end{tabular}


TABLA DE CONSTANTES FORMALES EN FACHADAS

PRINCIPALES

EDIFICIOS DE TAJIN CHICO Y EDIFICIO 42

\begin{tabular}{|c|c|c|c|}
\hline & EDIFICIO A & EDIFICIO C & EDIF. 42 \\
\hline CUERPOS ESCALONADOS & & & \\
\hline $\begin{array}{l}\text { CUERPOS ESCALONADOS } \\
\text { CON TALUD- } \\
\text { TABLERO/NICHOS/ } \\
\text { CORNISA VOLADA }\end{array}$ & & $\begin{array}{l}\checkmark \\
3 \text { cuerpos }\end{array}$ & $\begin{array}{c}\checkmark \\
4 \text { cuerpos }\end{array}$ \\
\hline $\begin{array}{l}\text { ESCALINATAS CON } \\
\text { ALFARDAS }\end{array}$ & $\sqrt{ }$ & & $\checkmark$ \\
\hline $\begin{array}{l}\text { ESCALINATAS Y ALFARDA } \\
\text { CON REMATE SUPERIOR }\end{array}$ & $\sqrt{ }$ & & \\
\hline $\begin{array}{l}\text { MACIZOS DE NICHOS EN } \\
\text { ESCALINATAS }\end{array}$ & & $\begin{array}{c}\qquad \\
\text { En grupos de } 3 \\
\text { y de } 7\end{array}$ & \\
\hline $\begin{array}{l}\text { MACIZOS DE NICHOS EN } \\
\text { ALFARDAS }\end{array}$ & & $\sqrt{ }$ & $\sqrt{ }$ \\
\hline TEMPLOS SUPERIORES & & & \\
\hline PLANTA CUADRADA & & & \\
\hline PLANTA RECTANGULAR & $\checkmark$ & $\checkmark$ & $\checkmark$ \\
\hline $\begin{array}{l}\text { USO DE GRECA } \\
\text { ESCALONADA }\end{array}$ & $\begin{array}{l}\quad \quad \quad \\
\text { Tanto en el } \\
\text { exterior como } \\
\text { en interior con } \\
\text { gran profusión y } \\
\text { diseños } \\
\text { variables }\end{array}$ & $\begin{array}{l}\text { En nichos } \\
\text { falsos y en los } \\
\text { macizos de } \\
\text { escalinatas }\end{array}$ & $\begin{array}{l}\text { Con profusión } \\
\text { y dirección } \\
\text { visual }\end{array}$ \\
\hline
\end{tabular}


TABLA DE CONSTANTES COMPOSITIVAS GEOMÉTRICAS EDIFICIOS DE LA PLAZA DEL ARROYO

\begin{tabular}{|c|c|c|c|c|}
\hline & $\begin{array}{l}\text { EDIF. } \\
16\end{array}$ & EDIF. 18 & $\begin{array}{l}\text { EDIF. } \\
19\end{array}$ & $\begin{array}{l}\text { EDIF. } \\
20\end{array}$ \\
\hline CR1 CUADRADO & & $\checkmark$ & & $\checkmark$ \\
\hline $\begin{array}{ll}\boldsymbol{R} \boldsymbol{R} 2 & \text { RECTÁNGULO } \\
\text { RAIIZZ } & \text { CUADRADA }\end{array}$ & $\checkmark$ & $\checkmark$ & $\checkmark$ & $\checkmark$ \\
\hline $\begin{array}{l}\boldsymbol{R} \boldsymbol{R} 3 \text { RECTÁNGULO RAÍZ } \\
\text { CÚBICA }\end{array}$ & & & & $\checkmark$ \\
\hline $\begin{array}{l}\boldsymbol{R A} \quad \text { RECTÁNGULO } \\
\text { ARMÓNICO O ÁUREO }\end{array}$ & $\checkmark$ & & & \\
\hline
\end{tabular}

TABLA DE CONSTANTES COMPOSITIVAS GEOMÉTRICAS

EDIFICIOS DE TAJÍN CENTRAL

\begin{tabular}{|c|c|c|c|}
\hline & $\begin{array}{l}\text { PIRÁMIDE } \\
\text { DE LOS } \\
\text { NICHOS }\end{array}$ & $\begin{array}{l}\text { EDIFICIO } \\
3\end{array}$ & EDIFICIO 5 \\
\hline CR1 CUADRADO & $\checkmark$ & $\checkmark$ & \\
\hline $\begin{array}{l}\boldsymbol{R} \boldsymbol{R} 2 \\
\text { CUADCTÁNGULO RAIIZZ } \\
\text { CUADA }\end{array}$ & $\checkmark$ & $\checkmark$ & $\checkmark$ \\
\hline \multicolumn{4}{|l|}{$\begin{array}{l}\boldsymbol{R} \boldsymbol{R} 3 \text { RECTÁNGULO RAİZ } \\
\text { CÚBICA }\end{array}$} \\
\hline $\begin{array}{l}\boldsymbol{R A} \\
\text { RECTÁNGULO } \\
\text { ARMÓNICO O ÁUREO }\end{array}$ & & $\checkmark$ & $\sqrt{ }$ \\
\hline
\end{tabular}


TABLA DE CONSTANTES COMPOSITIVAS GEOMÉTRICAS EDIFICIOS DE TAJÍN CHICO Y EDIFICIO 42

\begin{tabular}{|lccc|}
\hline $\boldsymbol{C R} \mathbf{1}$ CUADRADO & PUDIFICIO A & PDIFICIO C & PDIF. 42 \\
\hline $\begin{array}{l}\boldsymbol{R} \boldsymbol{R} \mathbf{2} \text { RECTÁNGULO RAİZ } \\
\text { CUADRADA }\end{array}$ & $\checkmark$ & $\checkmark$ & $\checkmark$ \\
\hline $\begin{array}{l}\boldsymbol{R} \boldsymbol{R} 3 \text { RECTÁNGULO RAÎZZ } \\
\text { CÚBICA }\end{array}$ & $\checkmark$ & $\checkmark$ & $\checkmark$ \\
\hline $\begin{array}{l}\boldsymbol{R} \boldsymbol{A} \text { RECTÁNGULO } \\
\text { ARMÓNICO O ÁUREO }\end{array}$ & $\checkmark$ & & \\
\hline
\end{tabular}




\section{EL ESTILO CLASICO DE VERACRUZ.}

El estilo clásico de Veracruz o "estilo Tajín" está íntimamente relacionado con su arquitectura-escultura, pues es a través de este medio como mejor se manifestó en el sitio, tal y como lo veremos en este tema.

Los estudios realizados por la brillante investigadora y mayista Tatiana Proskouriakoff, explican que este estilo consiste en el uso frecuente de un motivo repetido de diseño en el cual predomina un patrón de volutas o ganchos entrelazados e intercalados con elementos sueltos abstraídos de formas zoomorfas grotescas.

Proskouriakoff considera que el estilo Clásico de Veracruz es similar al de las tierras bajas mayas, pues, ambos, son primariamente gráficos, y su desarrollo conlleva a la elaboración de volutas y figuras grotescas; contrastando con la representación de la figura humana cargada de un fuerte naturalismo. Ambos estilos muestran preocupación por la belleza, regularidad de formas, y gusto por el ornamento. (Proskouriakoff, 1971: 558-559).

Estos motivos se encuentran principalmente en los bajorrelieves de los Juegos de Pelota Norte y Sur en El Tajín; pero también están en el corpus de esculturas en piedra, relacionadas con el Juego de Pelota, como son los llamados yugos, hachas y palmas, provenientes de diversos lugares del centro de Veracruz y del Tajín, y en general en los bajorrelieves 
esculpidos en columnas, tableros y altares de esta antigua ciudad de Mesoamérica.

A continuación se hará una revisión de este estilo característico que tuvo su desarrollo a la par que el del crecimiento urbano de la ciudad en tres fases; alcanzó su máxima expresión, tanto en la técnica escultórica como en sus detalles gráficos en el periodo epiclásico o posclásico (9001200 d.C.).

\subsection{Los tableros del Juego de Pelota Norte y Juego de Pelota Sur.}

Estos tableros y frisos grabados no sólo tienen relevancia cultural, sino también plástica. Aquí, podemos ver, en su plenitud, el estilo Tajín, enmarcando las escenas de los tableros o envolviéndolas. Estas, han sido estudiadas por T. Proskouriakoff, Michael Edwin Kampen, Román Piña Chan, Patricia Castillo, entre otros más, desde el punto de vista gráfico, iconográfico e iconológico. Algunas imágenes muestran, en su iconografia, influencias y similitudes con culturas como la maya, teotihuacana, mexica; sin embargo, el tratamiento visual de su lenguaje formal conserva los rasgos característicos particulares de la cultura de El Tajín. En consecuencia, estos edificios son los más importantes del sitio en lo referente al ritual del Juego de Pelota. 


\subsubsection{El Juego de Pelota Norte, Edificios 11/11 bis.}

Está conformado por dos edificios similares en su arquitectura y paralelos entre sí; su construcción corresponde a la etapa final de la Fase II de urbanización (750 a 900 d. C. según Piña Chan). Los dos edificios constan de muros medianos verticales denominados banquetas, seguidos de un muro inclinado a manera de gran talud rematado en varios cuerpos escalonados.

Adosados a la banqueta están los llamados "tableros" con los bajorrelieves, cuya ubicación es de la siguiente manera: dos en cada extremo y uno en el centro por cada edificio, dando un total de 6 y quedando los tableros uno frente a otro; a la vez, en los espacios intermedios hubo frisos esculpidos, pues se encontraron fragmentos de ellos.

Desde el punto de vista iconográfico, del cual no se profundizará demasiado, las imágenes plasmadas en los bajorrelieves muestran escenas relacionadas con el rito del Juego de Pelota, sus jerarquías sacerdotales, así como las diferentes advocaciones o manifestaciones de Quetzalcoatl, deidad suprema de El Tajín.

El friso mide $90 \mathrm{~cm}$. de largo X $15 \mathrm{~cm}$. de alto y el rectángulo mide $85 \mathrm{~cm}$. de largo X $60 \mathrm{~cm}$. de alto. 
Fig. 123. Edificios 11 bis y 11 del Juego de Pelota Norte durante los trabajos de restauración

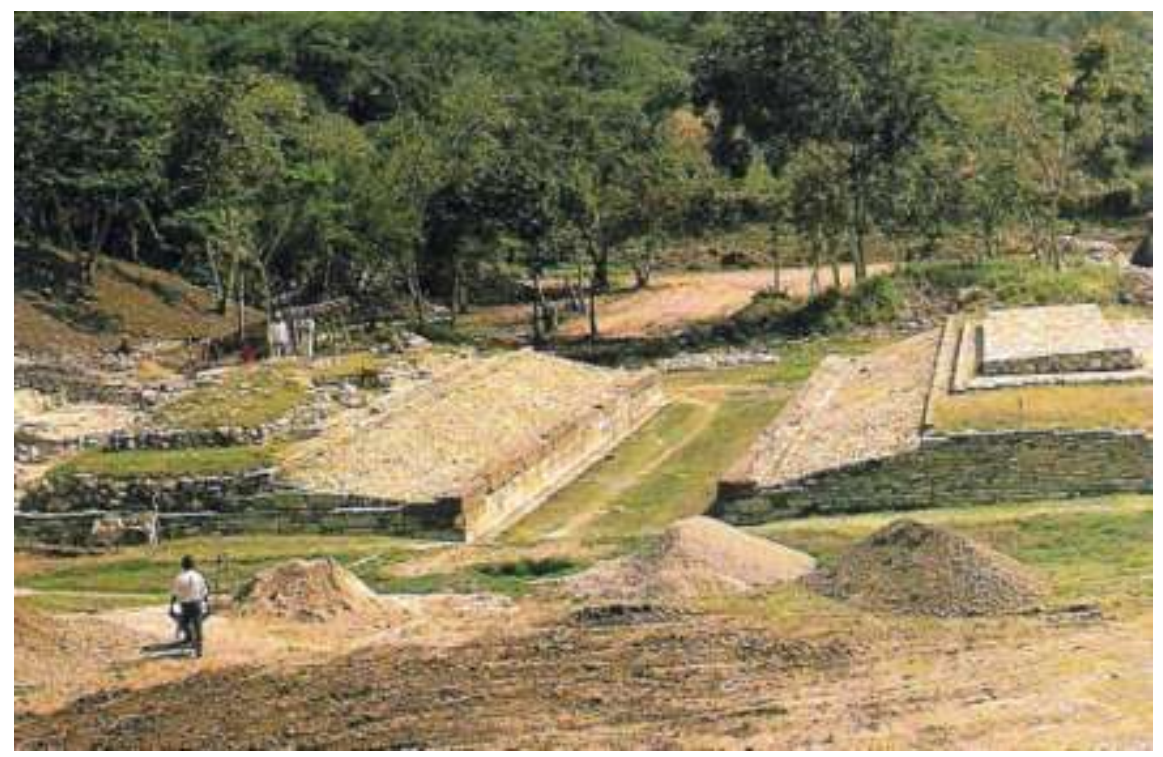

Fuente: México Desconocido.

Composición formal de los tableros:

Tienen un formato general o envolvente basado en el cuadrado, que a su vez se subdivide a manera de marco para encuadrar cada escena en 2 franjas verticales y una franja horizontal superior denominada "friso". Esta distribución compositiva es igual para todos 6 tableros.

Las Franjas verticales: En ellas se advierte con más claridad el estilo clásico de Veracruz: 
Fig. 124. Dibujos lineales a detalle de franjas verticales del Juego de Pelota Norte.
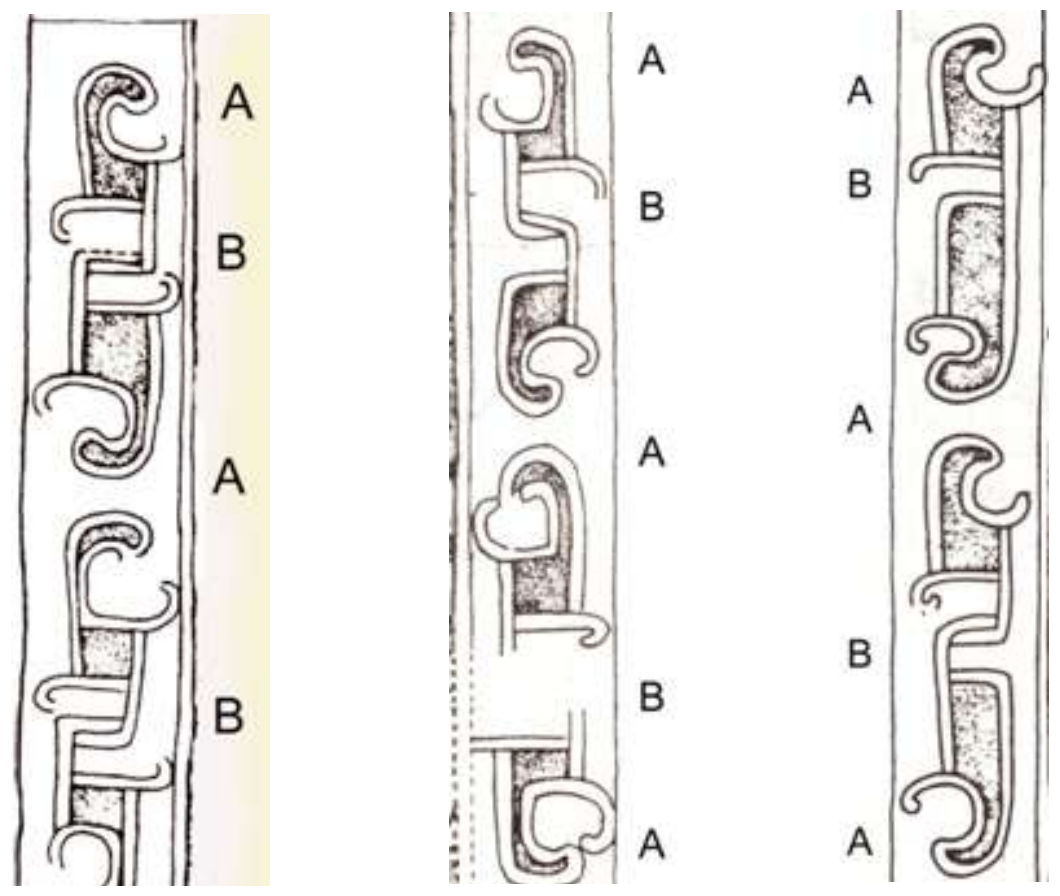

Fuente: Catálogo de escultura de El Tajín. C. Castillo Peña, Patricia.

Se distinguen dos tipos de motivos como constantes gráficas dentro de un patrón de repetición en las franjas: el motivo A que son los ganchos o volutas ${ }^{62}$ abiertas hacia un lado, hacia el otro o ambos, de líneas curvas, y el motivo B con un par de elementos rectos enlazados y con pequeños remates curvos. Ambos motivos con doble línea de contorno en su tratamiento de representación visual.

62 La voluta es una curva abierta o plana, compuesta por arcos de circunferencia enlazados entre sí, cuyos centros son los vértices de un polígono regular: triángulo, cuadrado, llamado núcleo o matriz. Fuente: www.tododibujo.com 
El friso superior: Es más ancho que las franjas verticales y sobresale del encuadre general en algunos tableros. Mide $90 \mathrm{X}$ $15 \mathrm{~cm}$, y el resto del tablero $85 \mathrm{~cm}$ de largo X $60 \mathrm{~cm}$ de alto.

Fig. 125. Tablero suroeste del Juego de Pelota Norte.

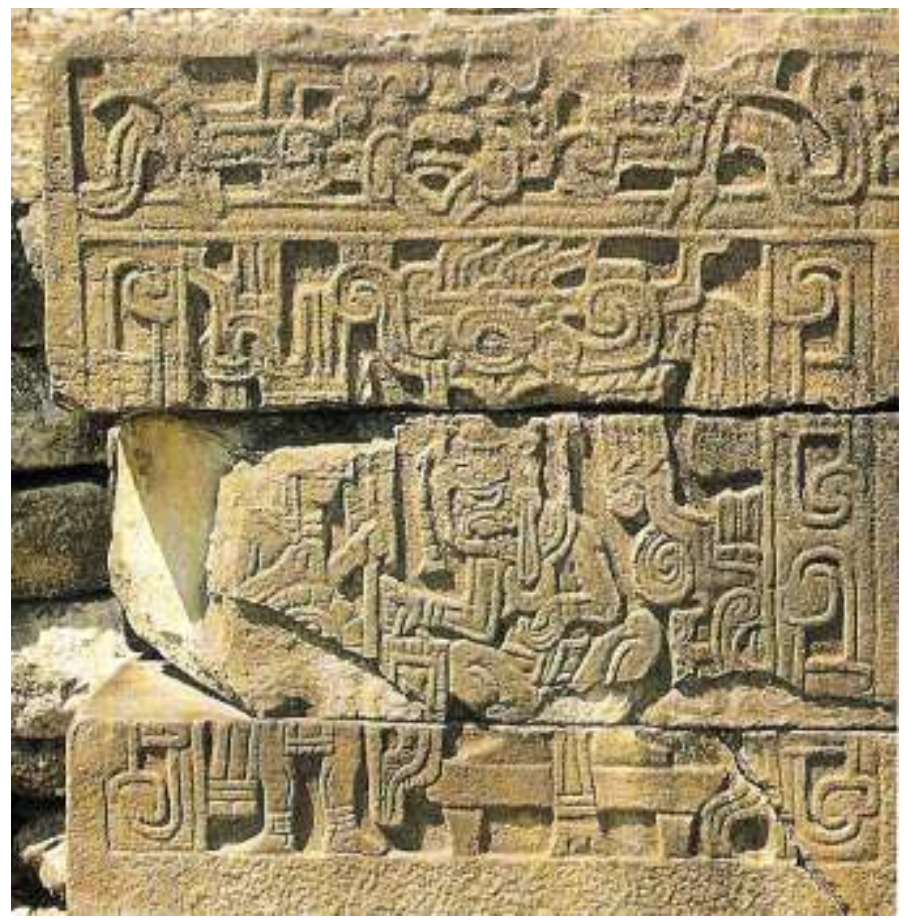

Fuente: Tajín, la ciudad del Dios Huracán.

En el friso se maneja una proporción o escala diferente; esto es notorio en el rostro y cuerpo del personaje antropomorfo representado, que es mayor comparado con los personajes de las escenas de los tableros.

Una constante visual es que su rostro siempre mira de frente en todos los frisos; su cuerpo puede estar de frente o perfil. 
La imagen naturalista-simbólica tiene varios grados de iconicidad, ya que se pueden reconocer sus rasgos faciales acentuados con ornamentos; de la boca sale un signo con dos volutas y un elemento triangular a un nivel más simbólico. Su cuerpo se desdobla en forma horizontal hacia la derecha y en otros tableros hacia la izquierda, con tres diseños diferentes. Por el tratamiento, proporción y composición de los frisos, se nota que tienen una relevancia e importancia mayor dentro del sistema estructural de los tableros.

Fig. 126. Frisos superiores de tablero noroeste, noreste y sureste con desdoblamientos del personaje en dirección derecha e izquierda; se observan los diferentes diseños circulares en su vientre.
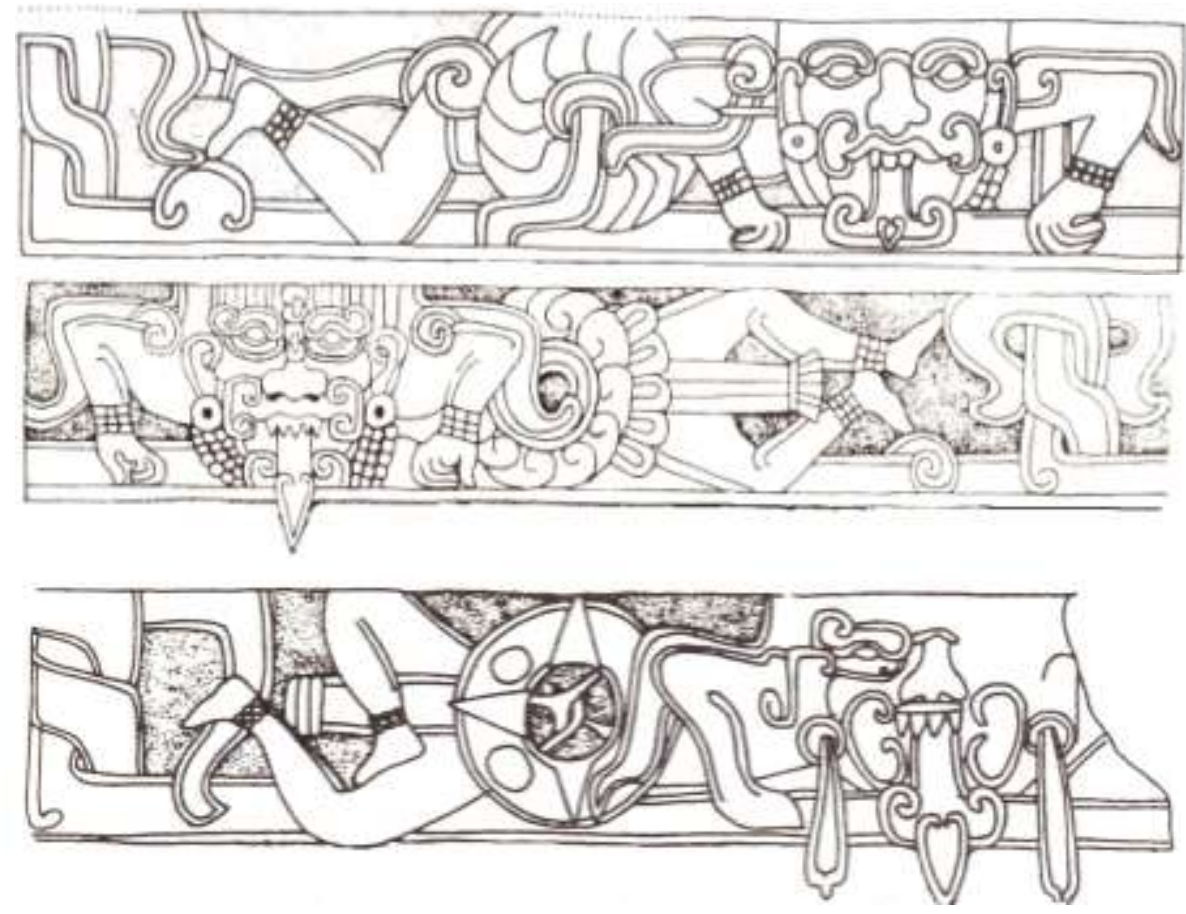

Fuente: Catálogo de escultura de El Tajín. C. Castillo Peña, Patricia. 
En los frisos hay varios modelos de entrelaces de ganchos trabajados con doble línea de carácter orgánico.

Fig. 127. Detalle de dibujo de entrelaces.
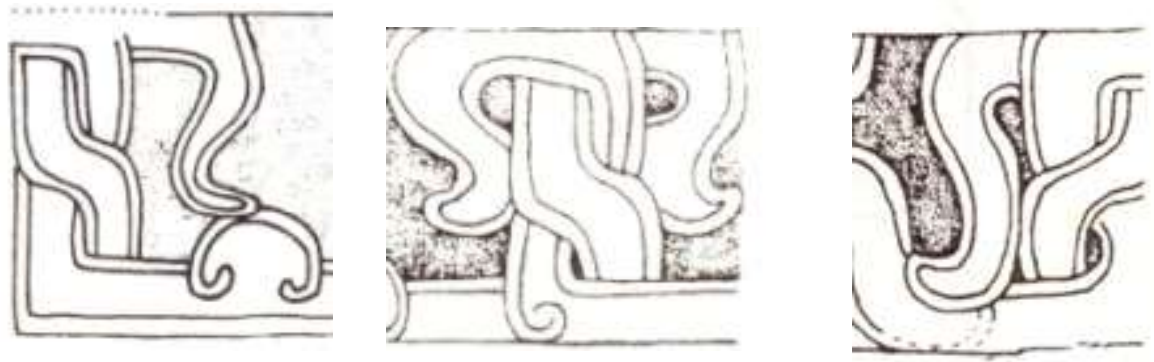

Fuente: Catálogo de escultura de El Tajín. C. Castillo Peña, Patricia.

Sobre las escenas: están conformadas por una composición generalmente utilizando un personaje central como punto de atracción; lo acompañan dos personajes, uno a cada lado, que le asisten o que intervienen en la acción de la escena principal. Sus rostros están de perfil, aunque su cuerpo esté de frente o de perfil.

La composición de los tableros casi no deja espacios libres; sin embargo prevalece el orden compositivo intencional del artista. Se utiliza la doble línea para contornear todas las imágenes, siguiendo el mismo trazo ondulante de los entrelaces. La doble línea infiere un carácter y fuerza visual a las figuras.

La representación gráfica expresa varios grados de iconicidad, pues en algunos casos se distinguen animales, en otros personas, objetos y en otros casos, como en los entrelaces y las volutas, quedan a un nivel más simbólico. 
Los personajes representados en los tableros, de acuerdo a la indumentaria que portan y a los detalles de sus ornamentos, representan la clase más alta en la sociedad en El Tajín: la clase sacerdotal, acompañada de sus deidades más importantes: Quetzalcoatl en sus diferentes manifestaciones simbólicas, a través de imágenes de seres antropomorfos. Todos ellos relacionados con el ritual del Juego de Pelota.

Fig. 128. Tablero sureste con personaje femenino del lado izquierdo, de los escasos ejemplos de representación de la mujer en el sitio.

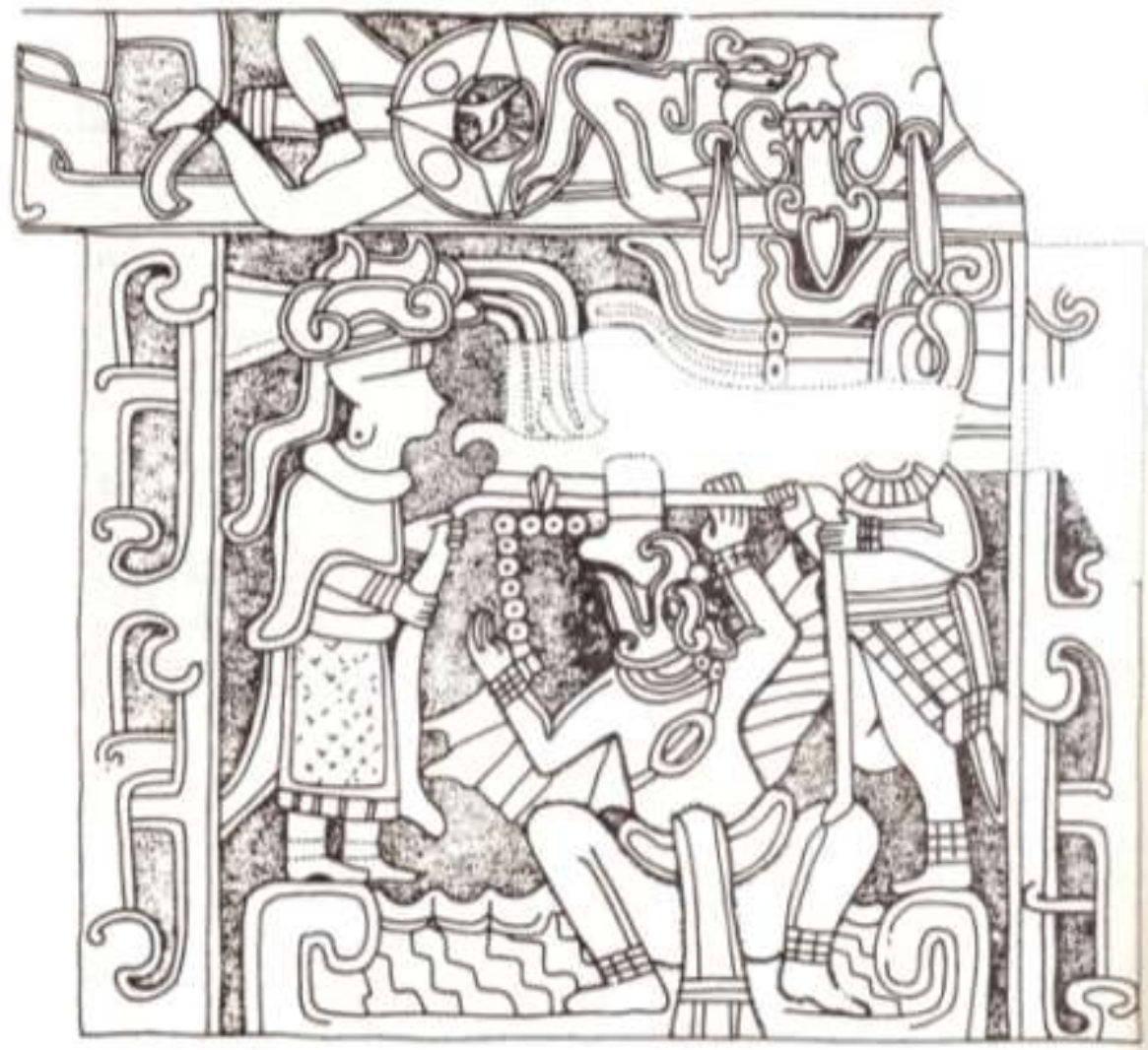

Fuente: Catálogo de escultura de El Tajín. C. Castillo Peña, Patricia. 
Fig. 129. Traza geométrica de Tablero Noroeste del Juego de Pelota Norte:

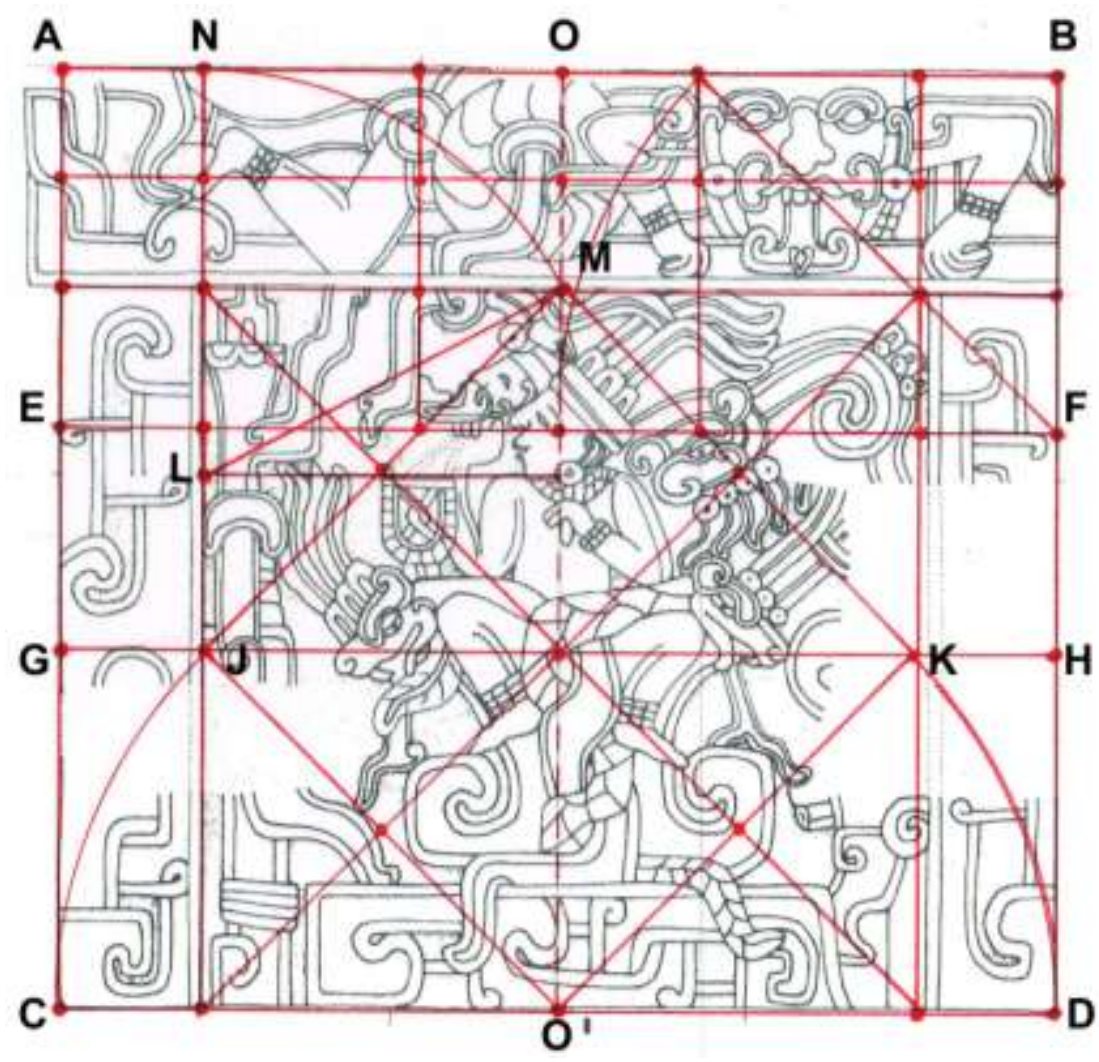

Fuente: Traza L. Valle/Dibujo Catálogo de escultura de El Tajín

RG: $A B C D$, de la recta $A C$ se obtiene su sección áurea con las rectas EF y GH obteniendo puntos gnomónicos de la composición.

Los RR2: O`JC y O`KD determinan ancho de franjas verticales. El RA: LMN determina ancho de friso superior.

Se usó grilla. 


\subsubsection{El Juego de Pelota Sur.}

El Juego de Pelota Sur ha sido considerado el más importante de la ciudad de El Tajín.

No se construyeron sus edificios de forma independiente, como las otras canchas en la zona, sino que se adaptaron a los muros de los Edificios 5 y 6 cumpliendo estas construcciones con la doble funcionalidad que tienen otros edificios de la zona. Su orientación es este-oeste; el Edificio 6 fue modificado en función de la cancha como estructura lateral, y es por esto que su fachada norte forma parte de la cancha; también presenta una serie de graderías para los espectadores del juego, dato que antes no se había registrado en el sitio sino hasta las exploraciones del año 1984, realizadas durante el Proyecto Tajin. Como elemento asociado al juego se localizó en esta estructura un fragmento pequeño de un yugo, elemento relacionado con el ritual.

La cancha es rectangular de tipo abierto, sin patios cabezales. El área de juego tiene 11 metros de ancho por 61.40 metros de largo; los muros que la limitan son verticales de 2.10 metros de alto, revestidos de piedra arenisca. Estos muros estaban coronados por un friso con bajorrelieves y una cornisa volada. La cornisa dejaba un espacio a manera de pasillo, el cual se juntaba a las construcciones de los edificios, por lo cual no deben ser consideradas como banquetas, propiamente dichas. En cada uno de los extremos de la cancha hay tableros, al igual que en el centro de cada muro, por lo que cuenta con 6 
en total (igual que en el Juego de Pelota Norte), formados por grandes bloques de piedra arenisca.

Fig. 130. Lado sur del Edificio 5 y Juego de Pelota sur.

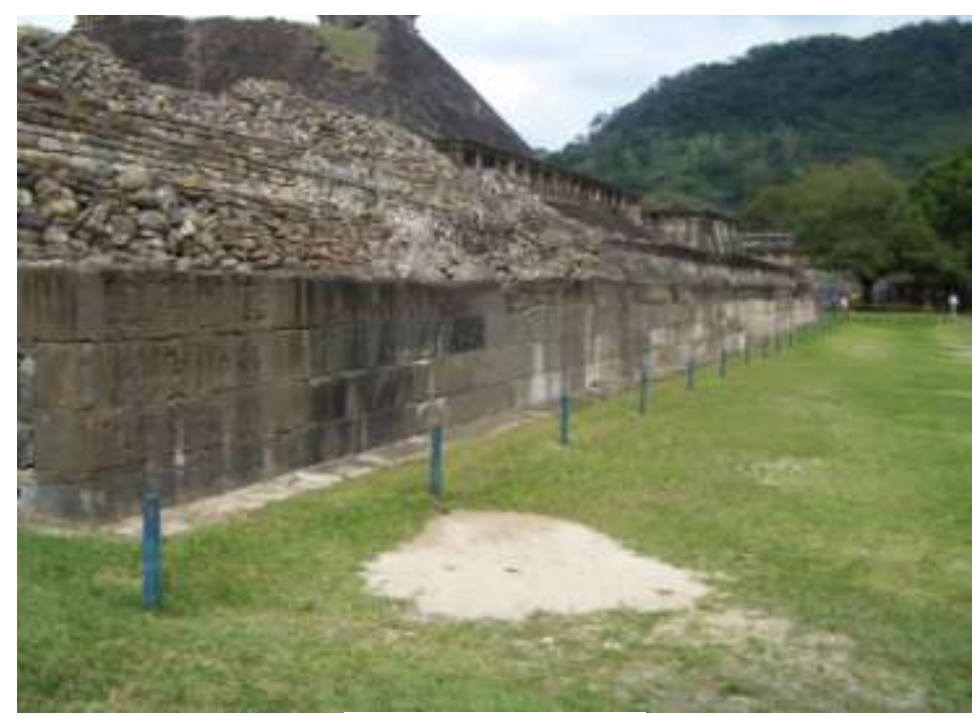

Fuente. L. Valle

Fig. 131. Tablero noroeste Juego de Pelota sur

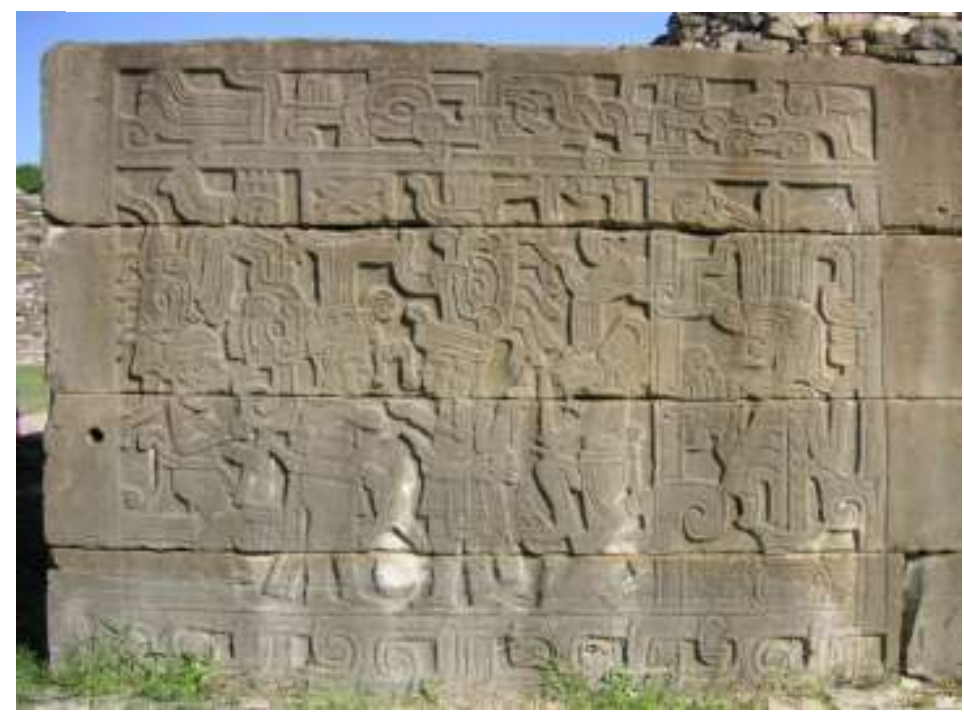

Fuente: Arqueología Mexicana. 
En el caso de los frisos y tableros del Juego de Pelota Sur se perciben cambios y nuevos elementos en la composición.

Se analizarán primero los cuatro tableros de las esquinas en general, ya que son semejantes; no sucede lo mismo con los tableros centrales, que se revisarán posteriormente.

\section{TABLEROS ADOSADOS AL EDIFICIO 5.}

Fig. 132. Tablero NO (noroeste)

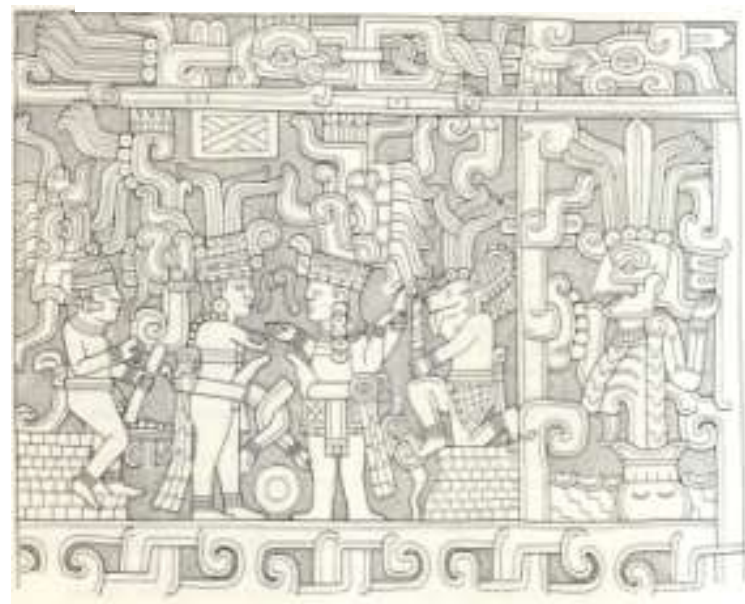

Fig. 133. Tablero NE (noreste)

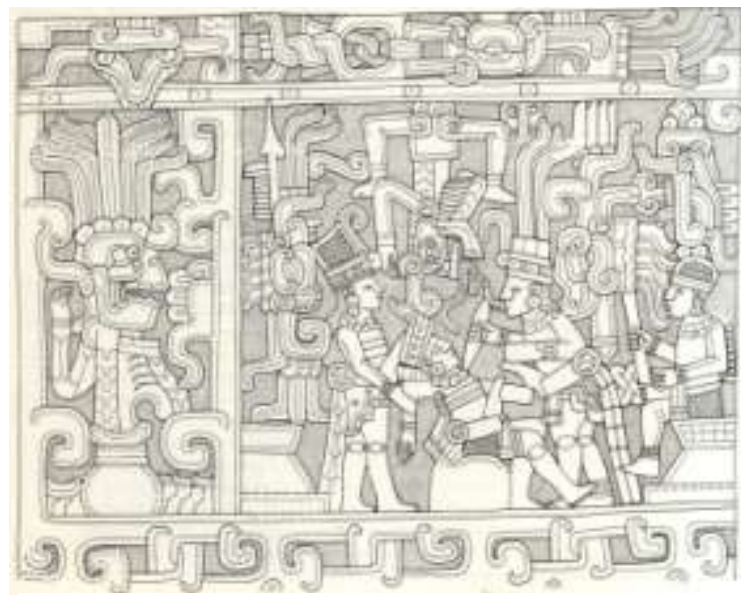

Fuente: Catálogo de escultura de El Tajín. 
Los tableros que corresponden a las esquinas son similares en su formato y estructura reticular: una franja inferior, un recuadro acompañando cada escena y el friso superior.

La franja inferior: es la franja de entrelaces y volutas con los motivos A y B señalados en los tableros del Juego de Pelota Norte, pero con algunos detalles añadidos al motivo B: aparecen otros pequeños elementos curvos en pares, o a veces triples, trabajados con doble línea, unidos a las paredes verticales del motivo. Este cambio es visible nada más en los tableros sureste y suroeste donde también se da el uso de doble franja de entrelaces. En la segunda inferior cambia el diseño, pero no pueden definirse con claridad los motivos por estar incompletos.

Fig. 134. Dibujo lineal de detalle escultórico de Tablero suroeste del JPS.

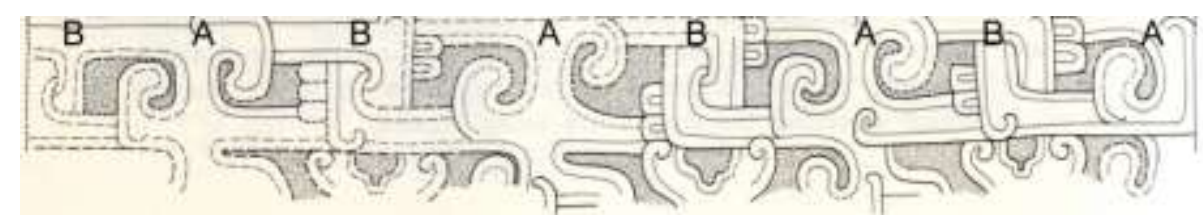

Fuente: Catálogo de escultura de El Tajín.

Estas franjas inferiores se consideran como linea de apoyo o linea terrenal, donde se posan los personajes de las escenas representadas.

Las franjas han sido muy importantes para identificar el estilo y características del lenguaje visual de los artistas de El Tajín.

Es realmente su propuesta original para representar una imagen simbólica, ya que su interpretación tiene varias lecturas: el viento, el movimiento, el agua. 
Los frisos: A diferencia de los frisos del Juego de Pelota Norte donde se podía ver un rostro con cuerpo desdoblado, en los frisos del Juego de Pelota Sur, las imágenes representadas son altamente simbólicas, semiabstractas.

Se encuentran tres motivos constantes con pequeñas variaciones de diseño a los que se les asigna un número para diferenciarlos de los motivos de las franjas. Estos motivos van unidos entre sí.

MOTIVO 1: Dos orientaciones; elementos anudados y signo de Ollin en el centro de un recuadro.

Fig. 135. Dibujos a detalle del signo de ollín del JPS.
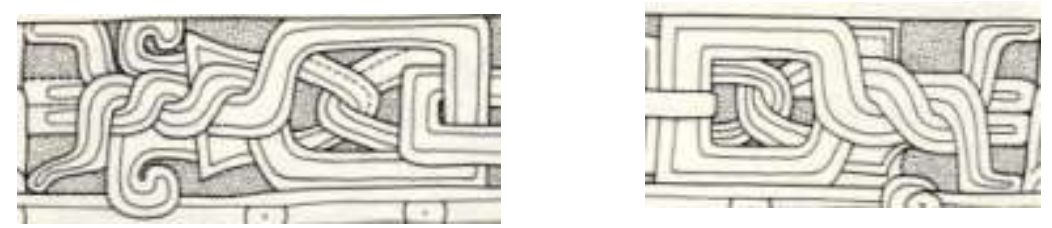

Fuente: Catálogo de escultura de El Tajín.

MOTIVO 2: Dos orientaciones; interpretación iconográfica: ojo con grandes párpados de volutas, entrelazado con remate de plumas preciosas estilizadas.

Fig. 136. Dibujos detalle escultórico de los frisos del JPS.
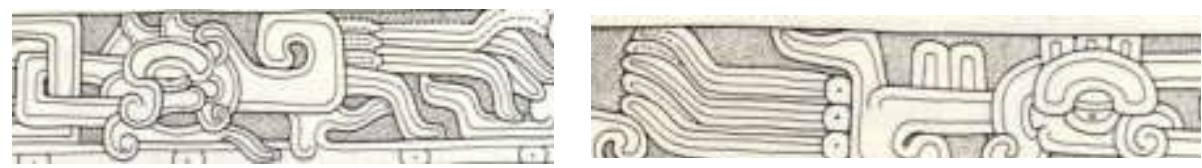

Fuente: Catálogo de escultura de El Tajín. 
MOTIVO 3: Aparece solo en dos tableros; iconografia: pico de ave estilizado con remates de volutas.

Fig. 137. Detalle escultórico del JPS
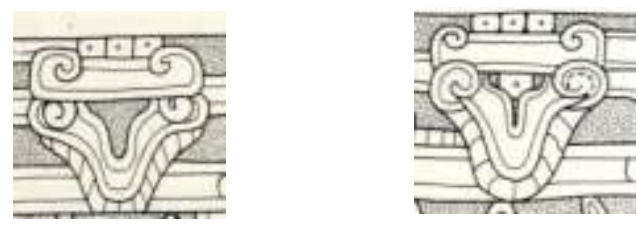

Fuente: Catálogo de escultura de El Tajín.

Ejemplo: Friso Noreste con los tres motivos:

Fig. 138. Detalle escultórico de parte superior de friso. JPS.

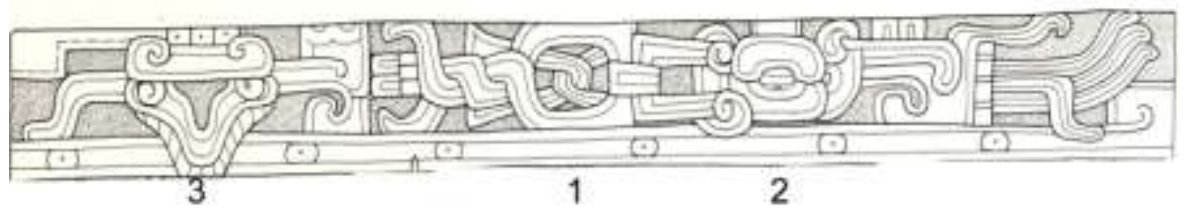

Fuente: Catálogo de escultura de El Tajín.

En la parte inferior de la franja hay pequeños círculos con un punto en su interior colocados a una distancia espaciada entre cada uno y que pueden sumar desde 3 a 8 . Se reconocen como chalchihuites o cuentas de jade en lenguaje iconográfico.

Al referirse al signo de ollin, ampliamente utilizado en el arte mesoamericano, es hablar de una imagen plenamente identificada como dos líneas divergentes -que constituyen cuatro polos contrarios- unidas en su centro, tal como lo sintetiza L. Sejourné y que simboliza el movimiento. ${ }^{63}$

${ }^{63}$ Sejourné, L., Pensamiento y religión en el México antiguo, Fondo de Cultura Económica, México, 2003. Pág. 108. 
Fig. 139. Diversas maneras de representación del signo ollín en el arte antiguo de Mesoamerica, a,b,c Teotihuacan; d,Códice Borbónico; e, Códice Florentino; f, Códices Borbónico y Borgia.

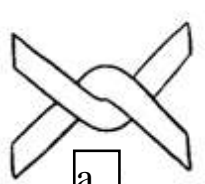

a

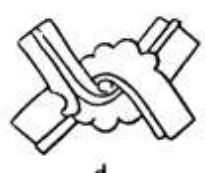

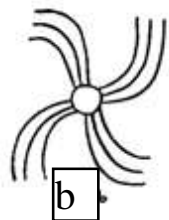

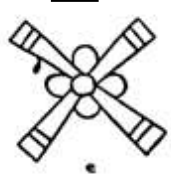

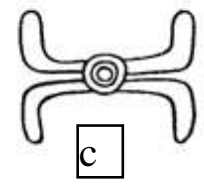

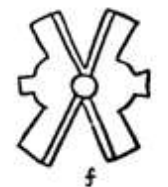

Fuente: Pensamiento y religión en el México antiguo. L. Sejourné.

Las escenas: La escena principal tiene un formato rectangular, casi cuadrado. Son mucho más complejas y recargadas visualmente, conservando el orden compositivo. Participan de 3 hasta 4 personajes principales; en algunos casos hay un quinto personaje mitológico que desciende a partir del friso superior.

Los personajes centrales están representados en forma simbólico- realista. Por su rica y fastuosa indumentaria de grandes tocados, se trata de personajes de alto rango y condición: sacerdotes como jugadores de pelota y deidades que participan en el ritual. Estas deidades aparecen como seres antropomorfos, con cuerpo de humano y cabeza de animal.

El tratamiento gráfico es igual que en los tableros del Juego de Pelota Norte, empleando la doble línea para el contorno.

Los personajes están de perfil, pero no estáticos. En el fondo de los tableros se identifica el motivo 2 utilizado en los frisos, 
pero más elaborado. También se ve el signo de ollin así representado:

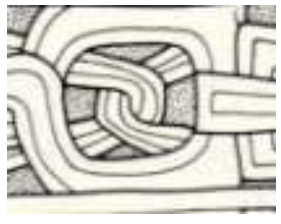

En los frisos,

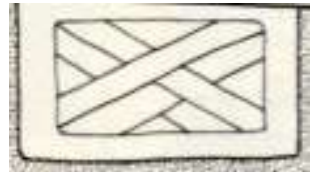

en las escenas,

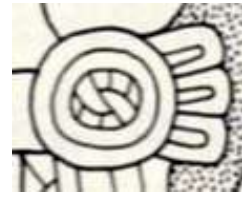

en la indumentaria de los personajes.

E1 recuadro: Todas las escenas tienen a un lado un recuadro que ocupa 1/3 del formato rectangular total horizontal. En él aparece siempre un personaje con cuerpo esquelético cuya parte inferior está sumergida en una pequeña olla o recipiente. Su rostro de calavera está de perfil observando la escena central del tablero. En dos de los tableros del Juego de Pelota Sur aparece del lado derecho, y su mirada apuntando hacia la izquierda; en los otros dos aparece en el lado izquierdo, apuntando hacia la derecha.

Fig. 140. Personaje constante en los tableros del Juego de Pelota Sur con dos orientaciones.

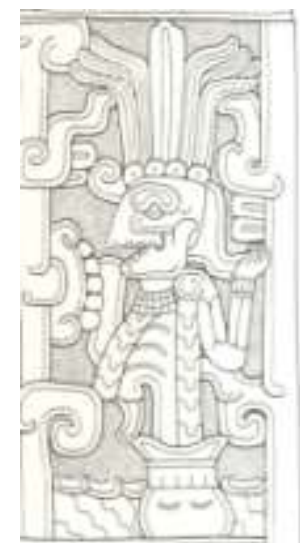

Fuente: Catálogo de escultura de El Tajín. 


\section{TABLEROS ADOSADOS AL EDIFICIO 6:}

Fig. 141. Tablero SO (suroeste)
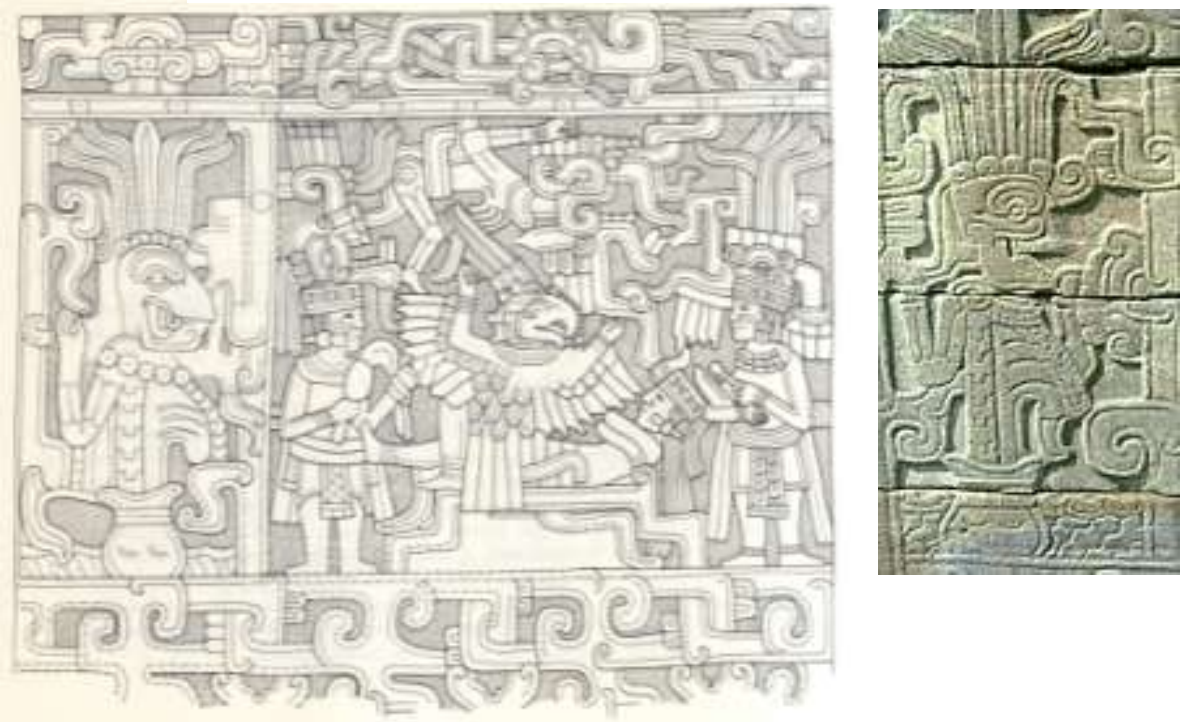

Fig. 142. Tablero SE (sureste)
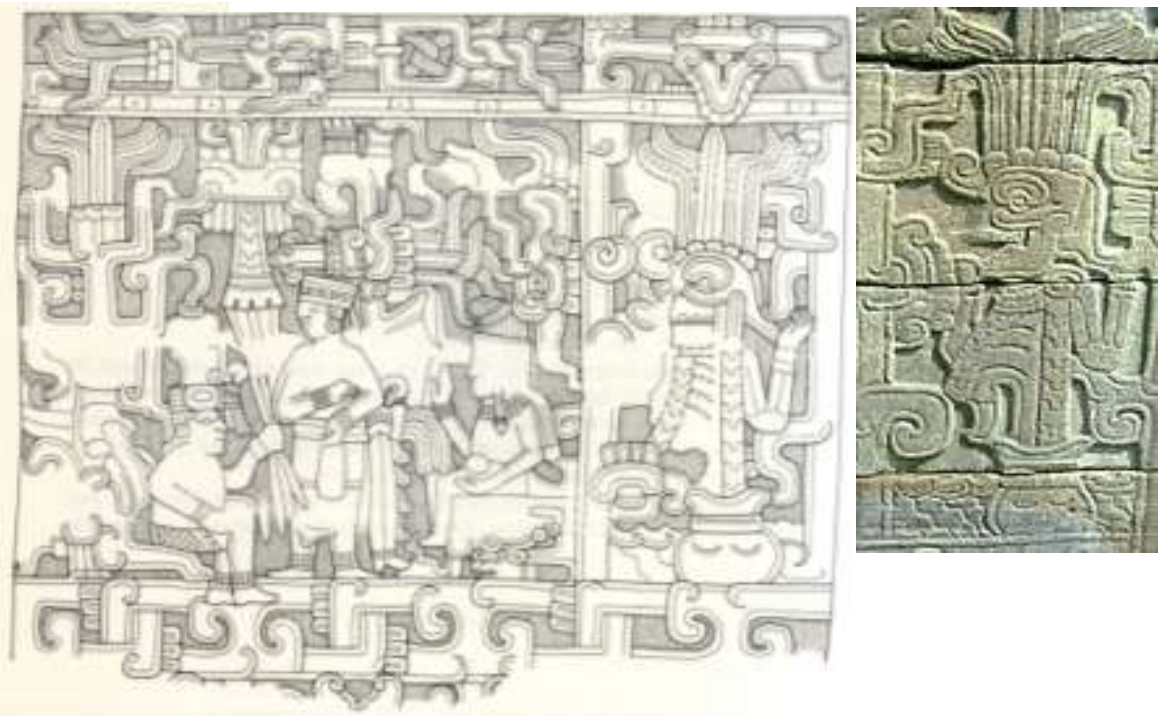

Fuente figs. 141 y 142: Catálogo de escultura de El Tajín. 
Fig. 143. Traza geométrica de Tablero Noroeste:

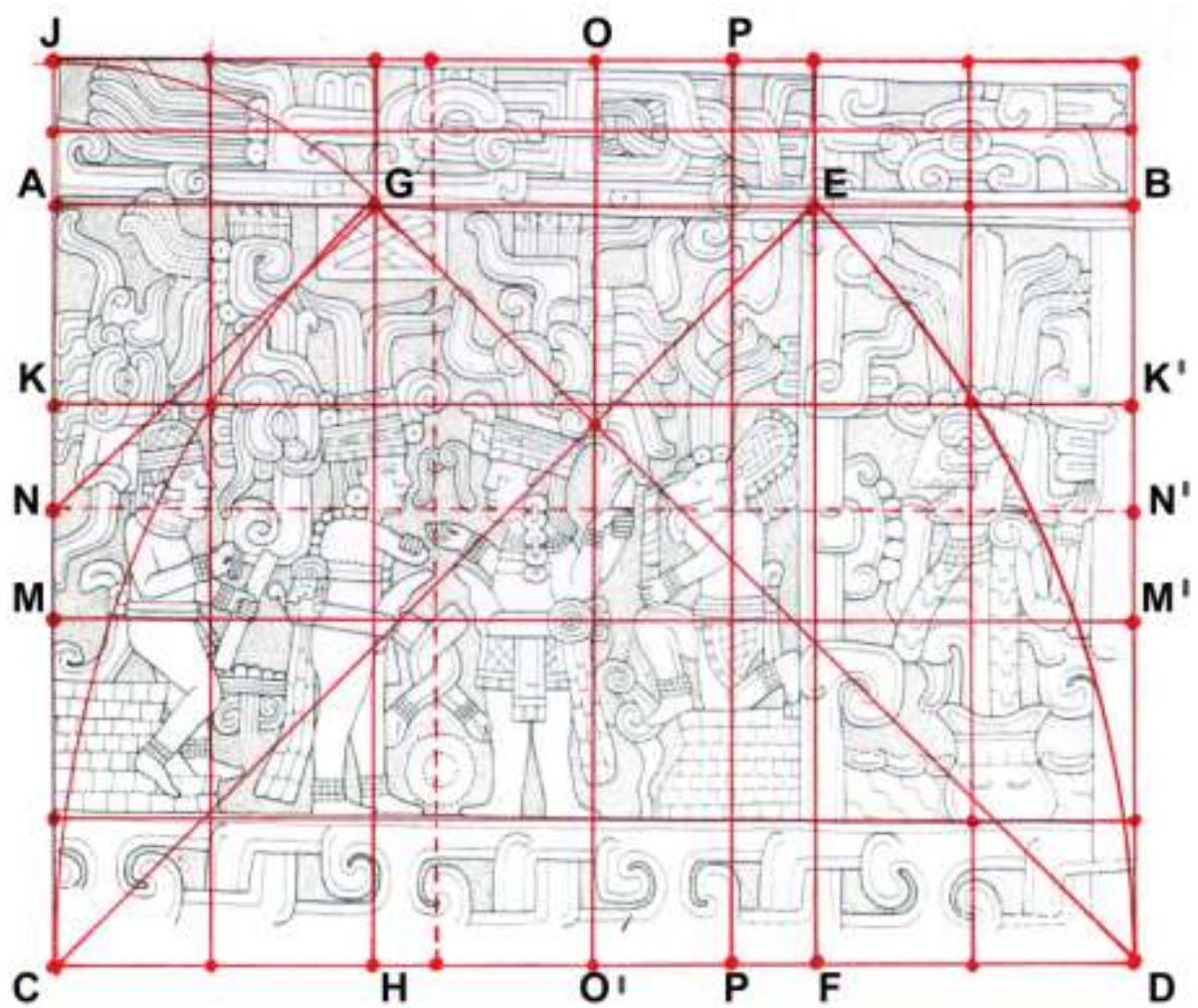

Fuente: L. Valle

RG: ABCD compuesto de $\boldsymbol{R} \boldsymbol{R} 2$ : CED.

EBFD delimita el área del recuadro con personaje calavérico.

$\boldsymbol{R} \boldsymbol{R 2}$ : DGC en donde GH marca eje de personaje.

$\boldsymbol{R} 2$ 2: NGJ ancho de friso superior.

A la recta JC se le obtiene su sección áurea con las rectas $\mathrm{KK}^{\prime}$, $\mathrm{MM}^{-}$en cuya área se encuentran todos los rostros de los personajes.

La proporción áurea de la recta JB es el punto P. La recta PP' es el eje de personaje con rostro de animal. 
Tableros centrales:

Los tableros centrales del Juego de Pelota Sur son posiblemente los más profusos y con mayor grado de complejidad que todos los descritos anteriormente por su posición en el centro de los muros de la cancha, el tratamiento especial en su diseño, proporción y composición, su alto contenido simbólico, etc.

Primeramente el formato es mayor que todos los tableros anteriores.

A diferencia de las anteriores, la escena central está enmarcada por los sus 4 lados de la siguiente manera: 8 franjas verticales distribuidas 4 a cada lado de la escena central, un friso superior y un friso inferior.

Fig. 144. Tablero central norte, Juego de Pelota Sur

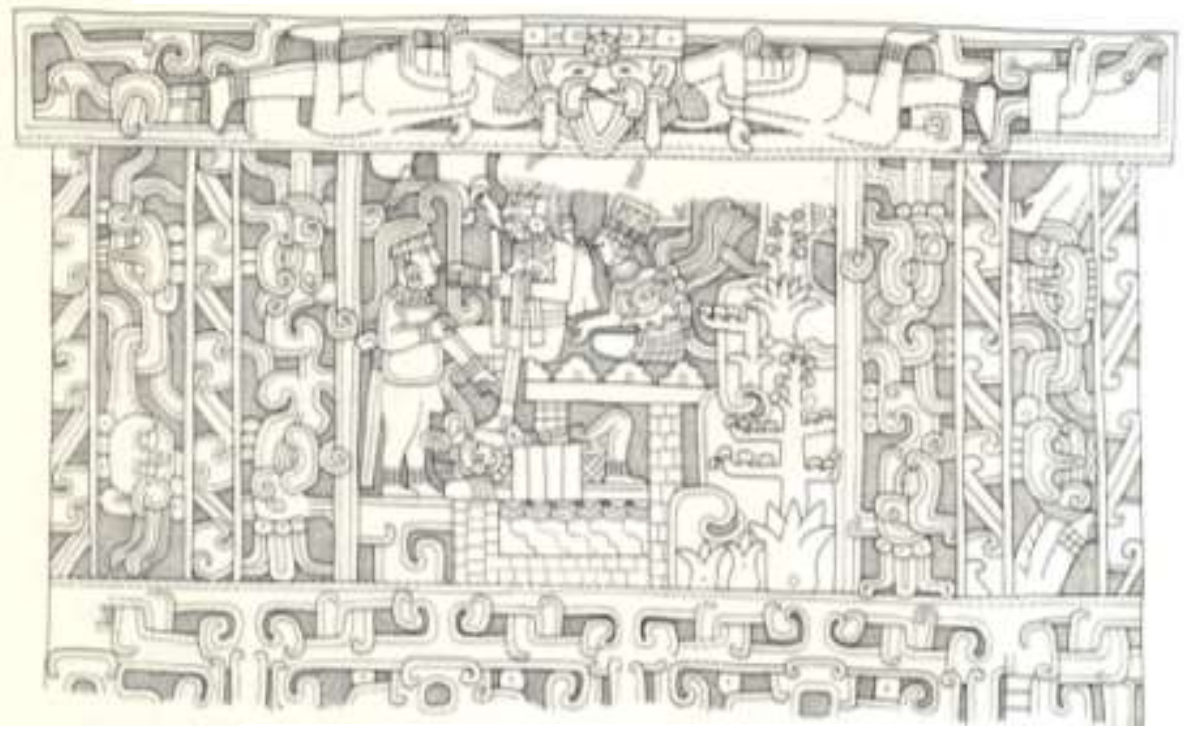

Fuente: Catálogo de escultura de El Tajín. 
Fig. 145. Tablero central sur, Juego de Pelota Sur

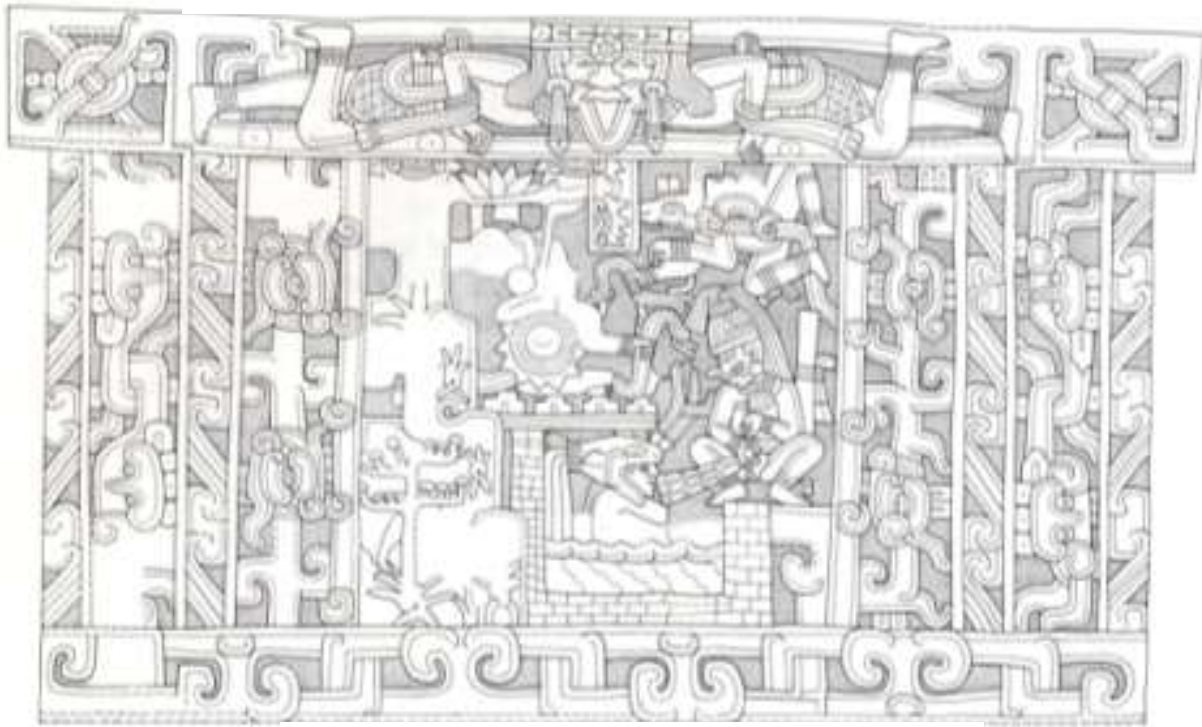

Fuente: Catálogo de escultura de El Tajín.

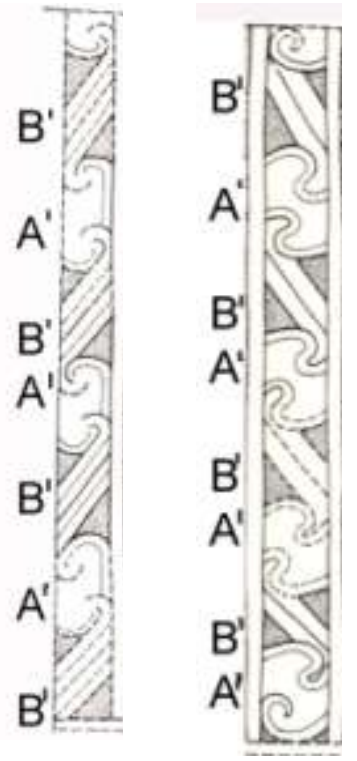

Las franjas verticales: A cada lado de la escena central hay cuatro franjas, dos anchas y dos delgadas intercaladas. En las franjas más estrechas y por su semejanza formal, son una variante de los motivos A y B de entrelaces, más estilizados: en el motivo $B$, aquí señalado como B', las líneas verticales se vuelven inclinadas y en el motivo A, con su variante $A^{\prime}$, las volutas son más pequeñas y comprimidas. Se presentan en dos direcciones. 


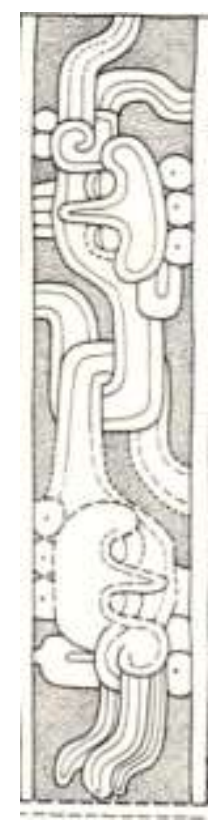

Intercalado con estas franjas le sigue la siguiente: se ve un diseño en simetría especular invertida a partir de un punto. De acuerdo a la descripción del Dr. Piña Chan, esta imagen representa el concepto dual que se manifiesta con la perspectiva en el diseño, creando dobles representaciones unidas por un centro, que se pueden observar desde cualquier ángulo y que en ocasiones son imágenes abstractas que tratan de la misma idea o representaciones de la deidad. 64

En la cuarta franja se identifica el motivo 2, descrito anteriormente; se trata del ojo con párpados de volutas y "chalchihuites" o cuentas de jade, también en simetría especular invertida. El elemento central son volutas sin un orden aparente. Puede verse, al igual que la franja anterior, desde varios puntos de vista y según Piña Chan es una de las muchas representaciones simbólicas que

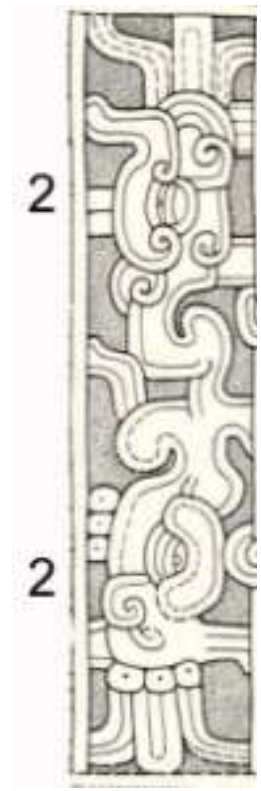

${ }^{64}$ Piña, Chan R., Castillo, Peña P., Tajín, la ciudad del Dios Huracán, Fondo de Cultura Económica, México, 1999, pág. 140. 
tiene Quetzalcoatl en los bajorrelieves de El Tajín.

La franja inferior: Esta franja se encuentra como base de las escenas y representa los entrelaces y volutas del estilo Tajín. El tablero central norte presenta doble franja.

Los frisos: Tienen una de las figuras más notables y conocidas de los bajorrelieves de El Tajín. Se trata de un ser divino y dual, pues muestra su cuerpo desdoblado hacia la derecha y hacia la izquierda extendiéndose en el espacio horizontal del friso. Su rostro refleja cierta sonrisa por su boca abierta y en forma triangular. Lleva un elemento circular en el entrecejo a manera de disco; porta orejeras con colgantes y un tocado en la cabeza. Su cuerpo viste con faldellín bordado elegantemente y lleva una faja anudada a la espalda de la cual se extiende una cauda o cola que entrelaza entre sus brazos flexionados y apoyados en los bordes del friso. Una de sus piernas está semiflexionada ocupando el primer plano de visión y la otra está detrás, dando la sensación de perspectiva. A cada lado y en los extremos está enmarcado en un cuadrete el glifo ollín, movimiento con forma de cruz y círculo en el centro.

Las escenas: Se encuentran enmarcadas en una envolvente rectangular casi cuadrada conservando la proporción general utilizada en las escenas de los demás tableros. Los personajes, que van de 3 a 4, están representados de forma naturalistasimbólica con la indumentaria de alto rango. Las escenas se desarrollan dentro de un templo almenado; se aprecia la representación del agua y ocupando un espacio importante 
una planta, que según los estudiosos, es la planta del maguey. Lo significativo es que en estas regiones costeras no crece naturalmente esta planta; sin embargo, tiene un significado religioso, pues de acuerdo a los antiguos códices, en la región del Altiplano se le rendía culto a Mayahuel, divinidad del pulque, que es una bebida ritual obtenida a partir del maguey.
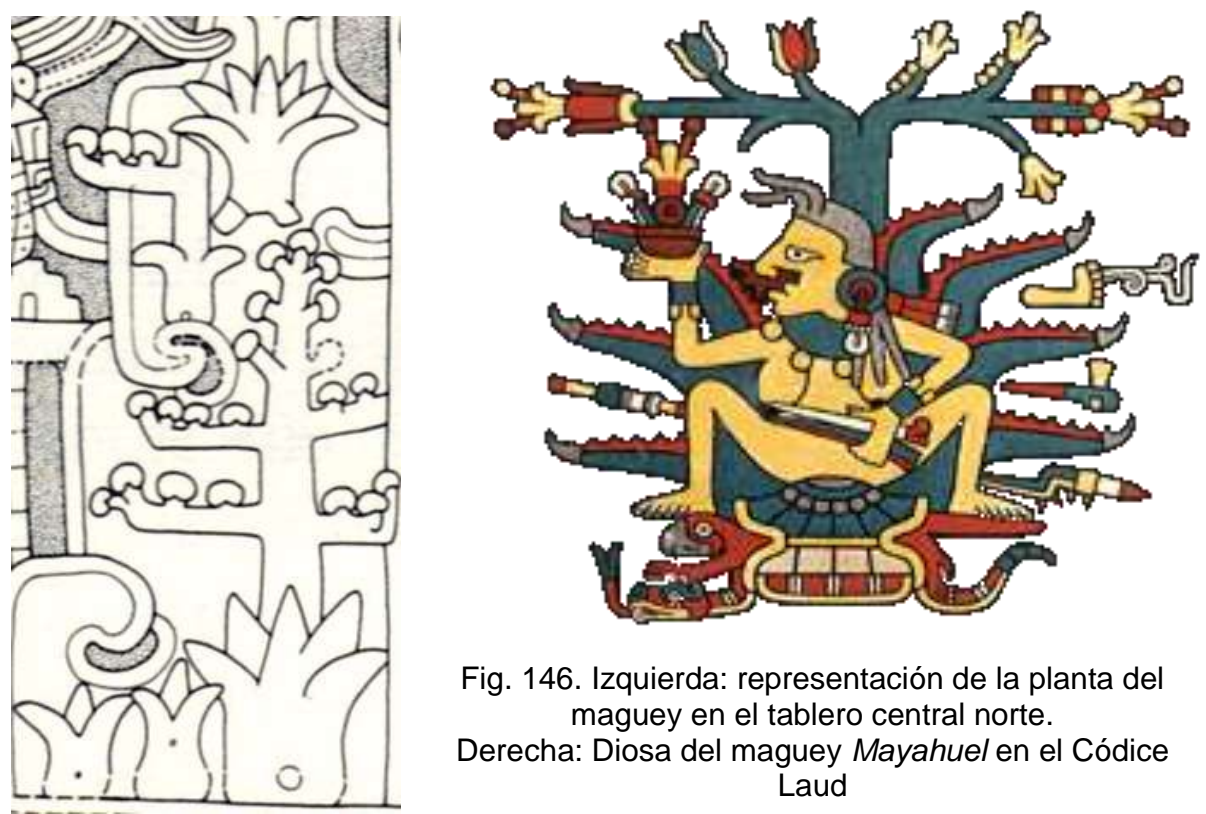

Fig. 146. Izquierda: representación de la planta del maguey en el tablero central norte.

Derecha: Diosa del maguey Mayahuel en el Códice Laud

En cuanto a la composición de estos tableros es diferente a los demás. Presentan una lectura dinámica, principalmente por la dirección visual que va de la horizontal a la vertical y de arriba para abajo; de ahí que la visión sea múltiple, en movimiento constante con destino final hacia el centro del tablero: como una espiral que va hacia el interior de la composición. 
Predominan las líneas de carácter orgánico; estas refuerzan la percepción de líneas compositivas hacia el centro interior, como en espiral, que se enganchan "anudando" todos sus componentes formales en una sola imagen integral.

Fig. 147. Traza geométrica del Tablero Central Sur

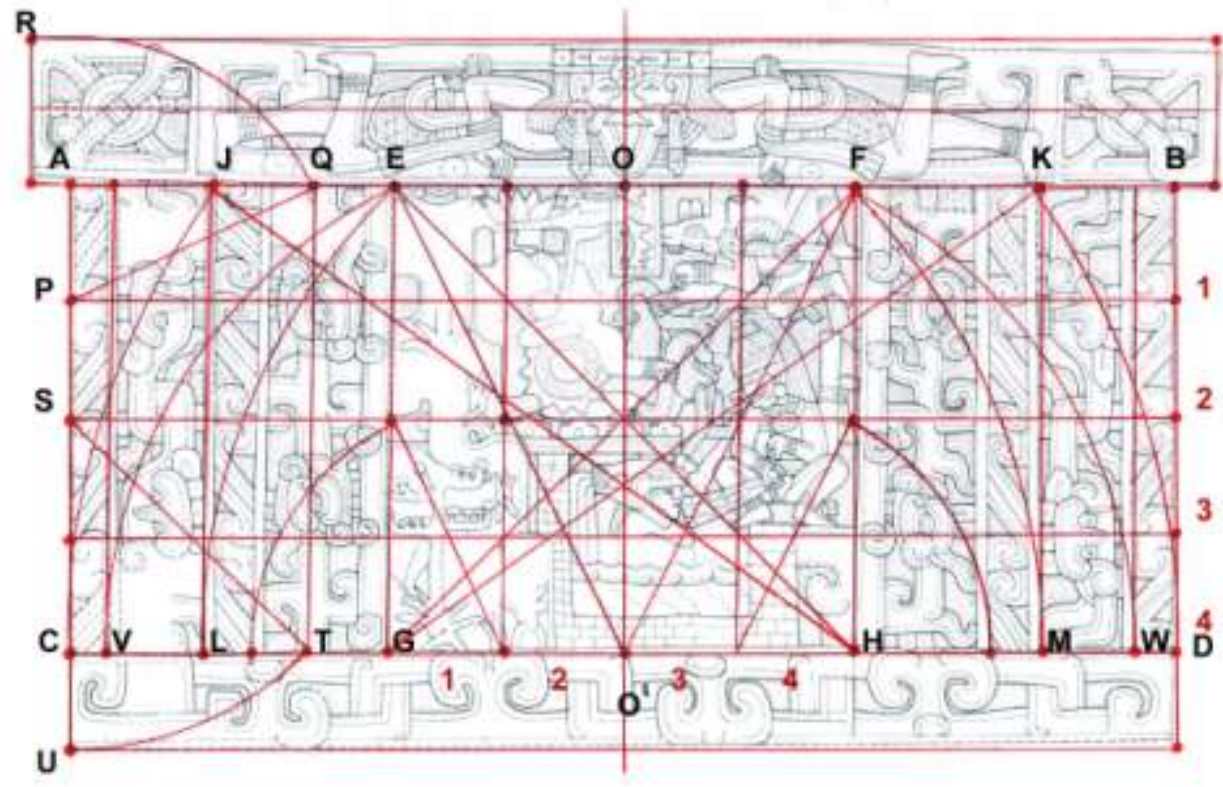

Fuente: L. Valle

Del RG: ABCD: $2 \boldsymbol{R} \boldsymbol{R} 3$ traslapados: HJC y GKD.

La recta $\mathrm{AC}$ y la recta $\mathrm{GH}$ se dividen en 4 partes iguales marcando puntos importantes dentro de la composición del tablero.

El ancho del friso superior se obtiene con $\boldsymbol{R A}$ : PQR y el de la franja inferior con RR2: STU.

Los RR3: HJC y GKD determinan el ancho de las franjas verticales exteriores. 
Los RA: O`EV y O`FW determinan las franjas verticales seguidas de las exteriores.

Los RR2: HEL y GFM son el ancho de las franjas siguientes en el orden de afuera hacia adentro.

Observaciones generales de los tableros:

La estructura reticular rectangular que predomina en los tableros obedece, principalmente, a la forma arquitectónica de los edificios que los contienen; su ubicación invariable es a pie de cancha, en las llamadas banquetas, que son las más próximas para los participantes del ritual del Juego de Pelota (jugadores). Se puede deducir que su diseño, proporción, morfología y semiótica, van encaminados a establecer un contacto visual dirigido a un objetivo específico en primera instancia, ya que, además de jugadores, en los tableros intervienen otros personajes a saber: sacerdotes, personajes de alto rango, etc.

Los entrelaces característicos del estilo clásico de Veracruz están presentes en los tableros, preferentemente formando parte de las franjas horizontales y verticales, aunque, también aparecen en los frisos, como remate en las esquinas, entremezclados con otros motivos, etc. La técnica visual utilizada en las franjas es la repetición rítmica de motivos entrelazados en secuencias horizontales y verticales ocupando 
un espacio importante en el campo visual general de los tableros.

Las volutas y entrelaces son el motivo gráfico unificador de la composición en los tableros; esto se debe a su insistente presencia a través de las variaciones formales en la totalidad de la composición. En el campo de la Semiótica, estos, funcionarian como signos básicos o lexemas, pertenecientes a un sistema codificante, en vias de su interpretación iconológica. 65

Dentro de la estructura compositiva, el elemento dominante, en general, es el friso superior debido a su ubicación, el peso visual, la proporción y escala utilizadas, abarcando todo el frente en los tableros.

Prevalece una composición orientada hacia el centro del rectángulo o cuadrado; en este punto se suceden las escenas y nuestra vista es atraída hacia ellas. Dentro de la complejidad y dinamismo de las imágenes, se logra un ordenamiento $\mathrm{y}$ equilibrio entre los ejes horizontal y vertical del esqueleto compositivo, que como se analizó en los ejemplos-muestra, se han utilizado en su traza geométrica $\boldsymbol{R A}, \boldsymbol{R} \boldsymbol{R} \mathbf{2}, \boldsymbol{R} \boldsymbol{R} 3$.

${ }^{65}$ Consultar el inciso 8.1 del Tema 8 del presente trabajo. 
El motivo que se encuentra presente repetidamente en todos los tableros, tanto del Juego de Pelota Norte como del Juego de Pelota Sur, es el ojo con volutas (motivo 2).

En cuanto a la posición que ocupa dentro del tablero, es visible:

- en el friso superior,

- como fondo de las escenas en sentido ascendente/descendente, oriente/poniente,

- como parte del tocado de los personajes,

- en repetición rítmica dentro de las franjas verticales.

Fig. 148. Tablero noroeste JPS en el cual se aprecian 5 ojos con volutas Indicados con zona de color.

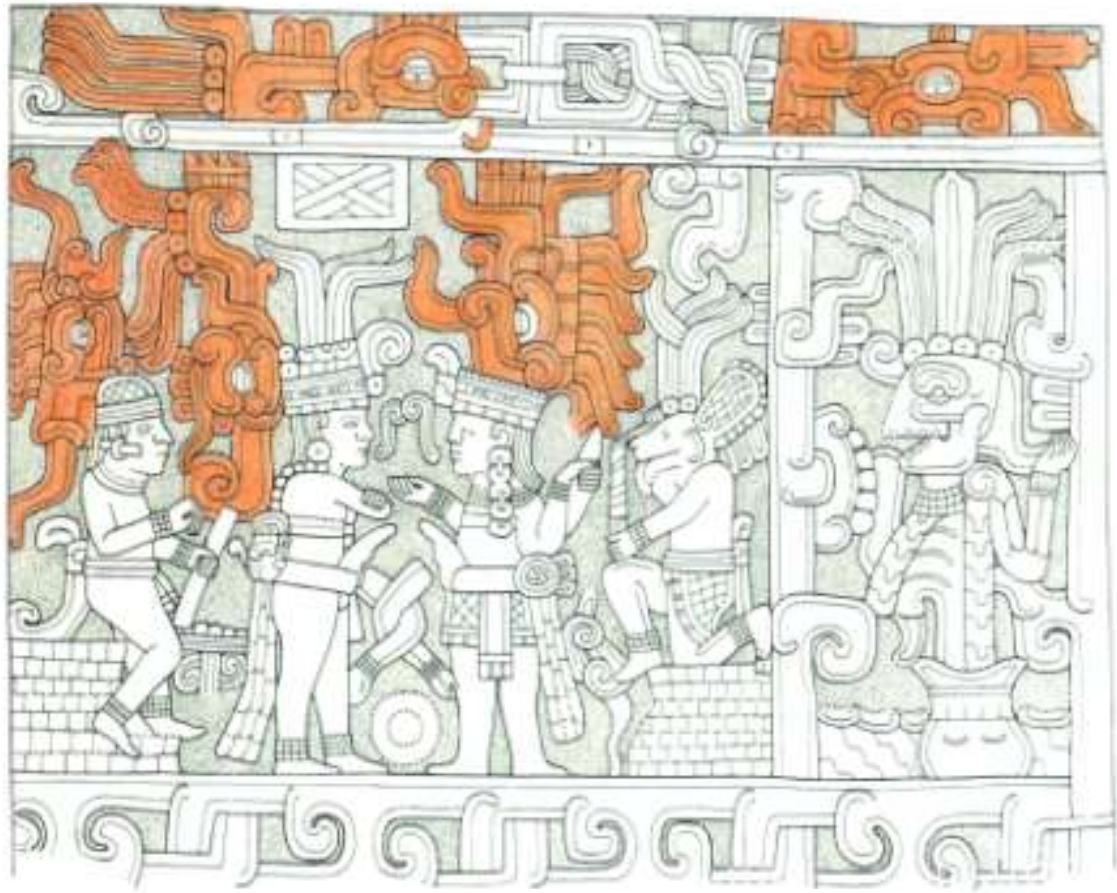

Fuente: Catálogo de escultura de El Tajín/L. Valle 
Las diferentes variables de representación gráfica son:

- con plumas estilizadas como remate o en los grandes tocados de la indumentaria ritual de los personajes.

- con volutas como remate

Otro motivo constante es el de ollin o movimiento, que aparece, preferentemente, en la indumentaria de los personajes; también se observa en los frisos y en el fondo de las escenas de los tableros:

Fig. 149. Detalles recortados de tablero JPS.

En la indumentaria: en la faja de la cintura y en bolsas de "copal".
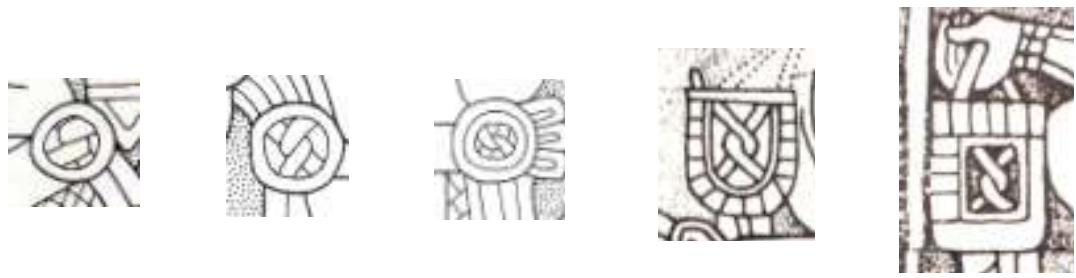

En los frisos

En el fondo de los tableros
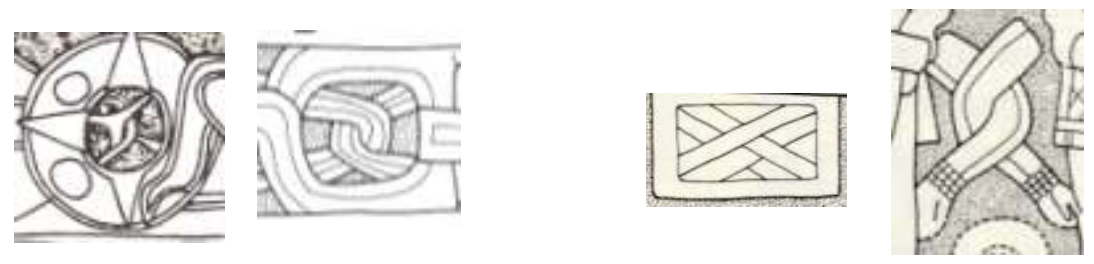

Fuente: Catálogo de escultura de El Tajín 
Los personajes antropomorfos representados son:

humano/ave, humano/canino, humano/conejo (de acuerdo a Piña Chan):

Fig. 150. Detalles recortados de tablero JPS.

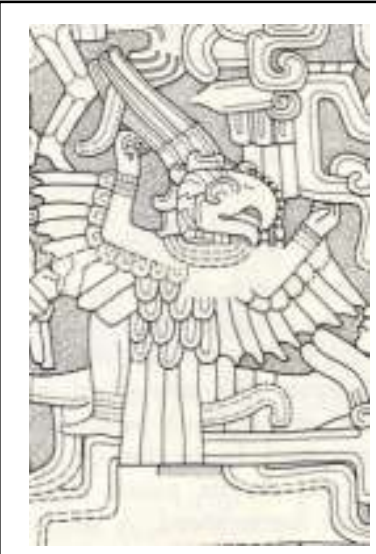

Humano/Ave

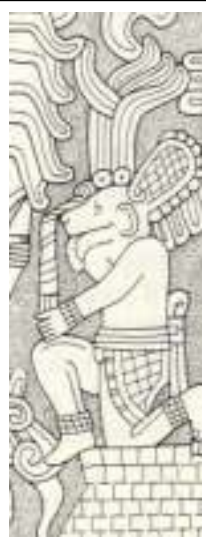

Humano/Can

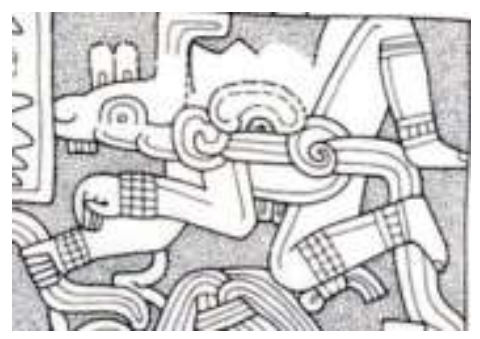

Humano/Conejo

Fuente: Catálogo de escultura de El Tajín

Flora y fauna representados: planta del maguey, tortuga, serpientes estilizadas con tocado de plumas preciosas y ojo con párpados de volutas.

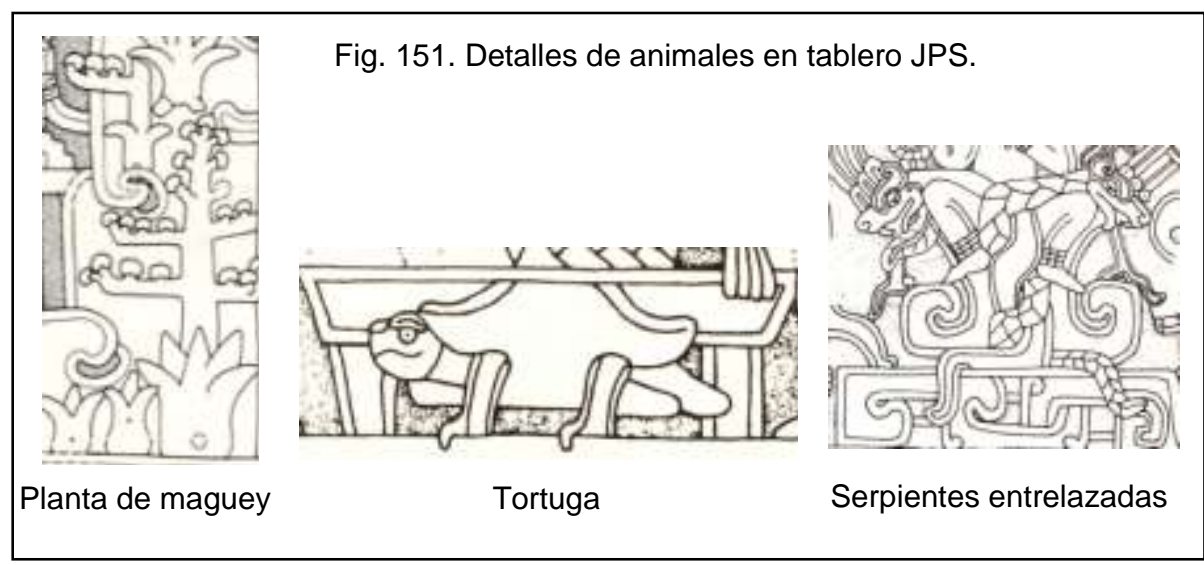

Fuente: Catálogo de escultura de El Tajín 
La proporción humana generalmente utilizada en los personajes de representación naturalista- estilizada en los tableros, y de acuerdo a los siguientes modelos seleccionados, es entre 4 a 5 cabezas:

Fig. 152. Figuras humanas representadas en tablero de JPS.
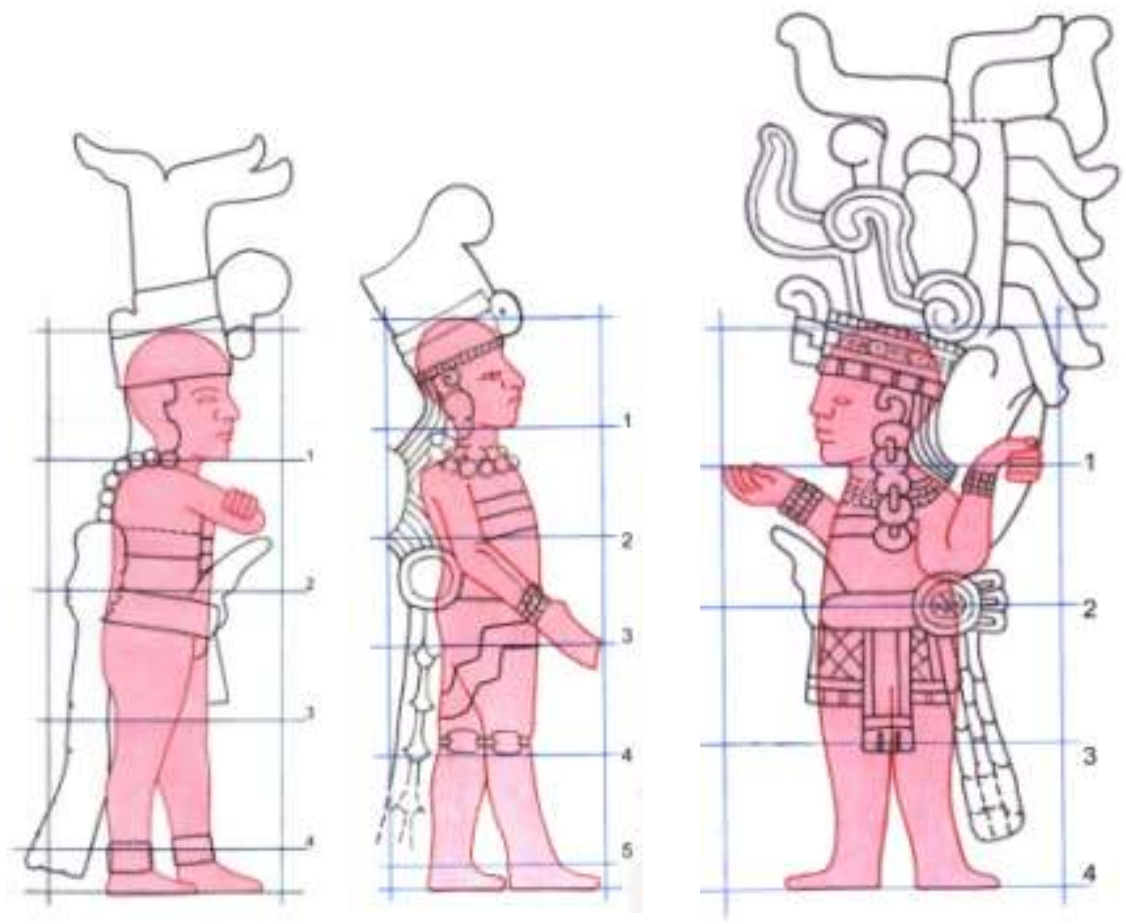

Fuente: L. Valle 
La arquitectura representada dentro de los tableros muestra los dos edificios de la cancha de pelota y templos almenados con agua en su interior:

Fig. 153. Detalle de Cancha para el Juego de Pelota con pelota central en tablero noroeste de JPS.

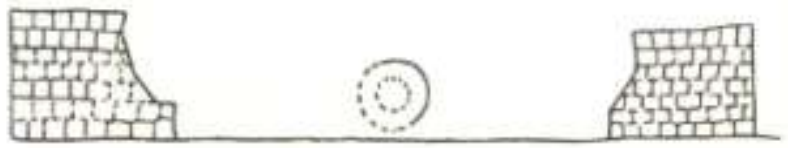

Fuente: Catálogo de escultura de El Tajín.

Fig. 154. Detalle de Templo con almenas y personaje en el interior, tablero central sur de JPS.

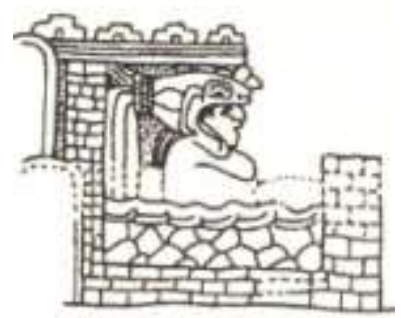

Fuente: Catálogo de escultura de El Tajín. 


\section{EL LENGUAJE VISUAL DE EL TAJÍN Y SU PAPEL EN LA CONSERVACION Y RESTAURACIÓN.}

\subsection{La importancia de los aspectos formal y semiótico de la imagen para la interpretación iconográfica e iconológica de la arquitectura-escultura de El Tajin.}

Si bien se ha intentado definir con claridad los objetivos y alcances del presente trabajo, es evidente que un tema como el del lenguaje visual de la arquitectura-escultura de El Tajín abre múltiples y ricas perspectivas de estudio que se entrelazan y relacionan a diversas áreas del conocimiento humano. En el presente punto se verán las cuestiones relativas al estudio del aspecto formal de las imágenes y su importancia para la interpretación de la obra artística realizada por la cultura de El Tajin; antes es necesario realizar en el primer momento un resumen conciso que dé una idea de las implicaciones metodológicas y epistemológicas en que se enmarca esta perspectiva, a fin de comprender los alcances que se persiguen.

El método iconológico ha ganado terreno como herramienta para la interpretación de las obras de arte en el siglo XX. Su creador fue Aby Warburg (1866-1929), y quienes lo llevaron a sus formas más logradas fueron Erwin Panofsky (1892-1968) y Rudolf Wittkower (1901-1971). 
Para la escuela del método iconológico, las obras artísticas son el producto de una cultura de las imágenes con significados complejos, e interactúan permanentemente con esa cultura que les dio origen; de ahí que forma y contenido sean inseparables en esta concepción y que intervengan en este tipo de análisis procesos comunicativos, semióticos y semánticos.

A través de la iconología y la iconografia se propone el análisis de las obras de arte en tres fases o niveles:

1. el nivel preiconográfico: su objetivo es describir e identificar lo representado materialmente (acciones, objetos, etc.);

2. el nivel iconográfico: donde la tarea consiste en identificar, con la mayor exactitud, el tema de la obra y los elementos plásticos con función simbólica, en relación con ese tema;

3. el nivel iconológico: en que se profundiza en el significado conceptual o ideológico, para lograr entender la obra en el contexto cultural en el que fue concebida ${ }^{66}$.

El método se adecua a cualquier época, géneros y soportes; así, es factible de emplearse - de ahí su interés para nuestro trabajo- en el análisis de formas simbólicas en la arquitecturaescultura, ya sea en lo que respecta al porqué de la utilización de ciertas tipologías, al lenguaje abstracto/simbólico y su

\footnotetext{
${ }^{66}$ Fuente:

http://ar.kalipedia.com/arte/tema/teoria-arte-iconografiaiconologia.html?x=20070718klparthis_80.Kes
} 
relación con la distribución de los espacios, su funcionalidad, etc.

Iconografia etimológicamente procede de los términos ícono y grafia, y significa "descripción de la imagen"; por ello trata con verdaderos repertorios de imágenes. La iconología, en cambio, se interesa por el significado conceptual de la obra y su interpretación: no es descriptiva como la iconografia, sino hermenéutica.

La lectura de las imágenes cambia de acuerdo con los medios de que se dispone en cada época. El método iconológico se apoya en aportes de la semiótica, ciencia cuyo objeto de estudio son, en lineas generales, los signos y su rol dentro del proceso comunicativo al que pertenecen, y la semántica (del griego semantikos, "lo que tiene significado"), que estudia específicamente los mecanismos de significado de los signos lingüísticos.

Este es, a grandes rasgos, el campo disciplinar en que se enmarca esta búsqueda.

Respecto de las cuestiones puntuales del aspecto formal del lenguaje visual de El Tajín a partir de la interpretación iconográfica e iconológica, el trabajo de Arturo Pascual Soto67 realiza, una correcta descripción del estado de situación actual de las investigaciones y un acertado planteo en lo que refiere a los lineamientos teóricos por tener en cuenta en dicho campo de estudio.

67 Pascual Soto, Arturo, El Tajín: en busca de los orígenes de una civilización. México, UNAM Instituto de Investigaciones Estéticas INAH, 2006, pp. 199-211. 
Pascual Soto señala en primer término el hecho de que El Tajín no creó su cultura de la nada, sino que es el resultado de cuatro milenios de historia. Así, el sistema de signos visuales que la identifica también fue heredado, pero alcanzó características distintivas en su lenguaje formal y fue notable por las múltiples posibilidades expresivas y comunicativas que se aprecian en él. En esta fase de madurez es que puede hablarse de una iconografia de El Tajín.

Sus antecedentes más cercanos se ubican cronológicamente al inicio del período Clásico, en que las tradiciones acusaban la fuerte influencia de Teotihuacan, y guardan estrecha relación con el llamado Estilo Clásico de Veracruz, ya que de él fueron parte los escultores de El Tajín. Este estilo destaca por el uso constante de elementos planos que se entrelazan y retuercen sobre sí mismos, y alcanzó su desarrollo pleno hacia el Clásico tardío.

Es importante tener siempre en cuenta el factor cronológico a la hora de abordar el análisis de una pieza, ya que la evolución que exhibe el lenguaje visual de El Tajin en las obras que se conocen, habla claramente de un proceso dinámico constante:

La morfología de los signos de El Tajín no siempre fue la misma, como tampoco permaneció sin cambios el estilo artístico de su representación. Sus transformaciones comportaron cambios en la realización formal de los signos $\mathrm{y}$, en algún caso, también introdujeron modificaciones en las 
reglas de su combinación, puesto que el estilo opera -aunque a nivel distinto- en el mismo sentido de la sintaxis. Sin embargo, las normas estilísticas son diferentes de las convenciones semióticas, aunque se hallen articuladas en un mismo evento de comunicación. En buena medida, los sistemas sígnicos no verbales (lenguaje visual) mesoamericanos se ajustaron a cánones estilísticos determinados para resolver problemas formales de la representación icónica y es sólo en este momento del propio desarrollo cuando son susceptibles de un estudio conjunto.

En el territorio donde floreció la cultura de El Tajín las cosas no fueron distintas, aunque parezcan más complejas. Sin embargo, pese a la profundidad cronológica de su cultura, sólo la producción sígnica del Clásico y Epiclásico local se ajusta a las caracteristicas formales de un estilo plenamente individual. No quiero decir con esto que el proceso de formalización del sistema sígnico no se hubiera iniciado antes, muy probablemente durante el período formativo, pero un tanto desafortunadamente los datos que poseemos sobre estas etapas iniciales del 
desarrollo iconográfico de la costa norte del Golfo siguen siendo incompletos ${ }^{68}$.

La mayor dificultad que se tiene al abordar el estudio de este lenguaje visual es que se desconocen aún los mecanismos de la lengua y el pensamiento de El Tajín. Así queda trunco el paso de lo iconográfico a lo iconológico, ya que no es posible apropiarse del significado preciso de las imágenes representadas:

Sin duda, el problema más serio es el de valorar la representatividad del material arqueológico en función de sus cualidades semióticas. Por un lado, el material cerámico, la única fuente de información que poseemos para el periodo Formativo, no permite llegar más allá de un limitado repertorio de símbolos. Por otro, es evidente que para deducir un código semiótico es necesario averiguar sus convenciones $\mathrm{y}$ éstas sólo pueden estudiarse a partir de textos icónicos concretos.

Por supuesto que la ausencia de verdaderos textos, esto es de asociaciones y relaciones entre diversos signos, no descalifica el valor icónico de las imágenes grabadas o pintadas en una vasija.

${ }^{68}$ Pascual Soto, op. cit., p. 203. 
La presencia de un signo aislado puede responder a un fin preciso y aunque no pueda establecerse el código que le subyace a través del estudio de ese particular objeto, este hecho no lo excluye de las normas de comunicación del propio sistema y de su implícita oposición conceptual con otros signos de igual naturaleza ${ }^{69}$.

Para entender este lenguaje, el salto necesario pasa por recomponer la estructura morfo-sintáctica del sistema, esto es, comprender las reglas que regían la correlación codificante entre los signos que lo componen. Para ello se debe identificar en primer lugar, las unidades minimas presentes en los diferentes textos icónicos que han llegado hasta nosotros, a partir de su aspecto formal y de las condiciones que propician su ocurrencia; una vez realizado este paso inicial hay que proceder al análisis sintáctico.

Ante este panorama, Pascual Soto ha optado por clasificar e intentar ordenar las imágenes $\mathrm{y}$ los signos esculpidos o pintados en El Tajín teniendo como supuestos teóricos principales aquellos derivados de los estudios semióticos de Lotman y Eco. Sobre esta base distingue:

- signos básicos o lexemas: son las unidades mínimas de significación de

69 Pascual Soto, A., op. cit., p. 205. 
un lenguaje $y$ de un sistema comunicativo. En nuestro caso son los signos icónicos que no pueden descomponerse en imágenes más simples: el nicho, la greca escalonada, los ganchos o volutas, el signo de ollín.

- función sígnica: son imágenes compuestas por la suma o concentración de lexemas, cuyo significado, por ende, surgirá de la combinación del significado de sus componentes, y será distinto del producido por la simple enumeración aislada de los mismos. En nuestro caso, un relieve puede entenderse en sí como una función sígnica.

- asociaciones signicas: se encuentran entre ambos niveles de información (los lexemas y las funciones sígnicas) Se trata de la suma de unidades minimas de significación que fueron expresadas gráficamente poniendo un signo en relación con otro $u$ otros a través de normas precisas de asociación por contigüidad, sobreposición o inclusión. Normas que, por lo general, coexistieron en las más complejas funciones sígnicas del Clásico tardio ${ }^{70}$.

\footnotetext{
${ }^{70}$ Pascual Soto, A., op. cit., p. 203.
} 
Se ha de tener siempre en claro que los signos (entendidos en la perspectiva de Lotman como sustituciones materiales de conceptos) no pueden existir como tales si no es dentro de un sistema organizado de comunicación. La formación y articulación de un complejo codificante como el del lenguaje visual de El Tajín es el resultado de la amalgama de varios sistemas más sencillos. En esta amalgama, uno de los sistemas está llamado a desempeñar el rol dominante para poder regular la combinación de los sistemas subordinados, dado que, siempre según Lotman, la vigencia de un complejo codificante depende directamente de su capacidad para cambiar manteniendo, simultáneamente, la memoria de los sistemas de estados que le han precedido.

En este punto, y recordando que el propósito central de su tarea es restablecer un nivel metasemiótico de los signos icónicos de El Tajín, Pascual Soto advierte que dicho objetivo no llegará a buen puerto, dadas las particulares características de los objetos arqueológicos, si se olvida la dicotomía sincronía-diacronía establecida por Saussure ya en los inicios de la lingüística y la semiótica. Sincrónico es todo lo referido al aspecto estático de un sistema de signos, y diacrónico todo lo que guarda relación con sus evoluciones en el tiempo. Son fenómenos opuestos y complementarios: todo texto nuevo (obra, en este caso particular) actualiza el sistema y modifica textos pertenecientes a estados precedentes, pero los materiales arqueológicos hallados en El Tajín no hacen posible determinar con precisión los sucesivos estados diacrónicos. 
Como resultado de esta carencia hay importantes lagunas en la línea temporal y el modelo sintáctico general sólo puede intentar reconstruirse a través de muestras fragmentarias. Pascual Soto ve la solución a este estancamiento utilizando los que él denomina modelos sintácticos actualizados:

$$
\begin{aligned}
& \text {...por modelo sintáctico actualizado } \\
& \text { entiendo el estado concreto de un mismo } \\
& \text { conjunto de normas de producción sígnica. } \\
& \text { En este caso, el estatuto sincrónico de } \\
& \text { cierto número de textos resulta de su } \\
& \text { correspondencia ideal con la forma misma } \\
& \text { de significar de los objetos arqueológicos, } \\
& \text { relacionada con una concepción particular } \\
& \text { del tiempo que resulte contemporáneo en } \\
& \text { términos de la arqueologia. Sólo el estudio } \\
& \text { de las transformaciones de los modelos } \\
& \text { sintácticos actualizados -cuya vigencia se } \\
& \text { expresa en términos de fases } \\
& \text { arqueológicas- permitirá la deducción de } \\
& \text { un modelo sintáctico general, dentro del } \\
& \text { cual se reconozcan los modelos sintácticos } \\
& \text { actualizados en diferentes textos icónicos }{ }^{71} \text {. }
\end{aligned}
$$

El aspecto formal de las imágenes y los signos representados en los edificios de El Tajín debe describirse y consignarse de acuerdo con estas lineas de investigación, para llegar así, a partir de su asignación a un determinado modelo sintáctico

\footnotetext{
${ }^{71}$ Pascual Soto, A. op. cit., p. 209.
} 
actualizado, a la determinación del hipotético modelo sintáctico general. Si se logra este avance, el paso de la etapa iconográfica a la iconológica verá su camino allanado, y se podrá tener acceso a la cautivante riqueza sugerida por este complejo lenguaje visual.

\subsection{La réplica escultórica, ejemplo de la conservación y difusión del lenguaje visual de la arquitectura-escultura de E1 Tajin.}

Es innegable que a través de la historia de la Humanidad la reproducción de esculturas, por el carácter único de estas expresiones artísticas, ha sido una via provechosa $\mathrm{e}$ insustituible para la difusión del patrimonio cultural. José Antonio Aguilar Galea ${ }^{72}$ clasifica en tres ramas principales las líneas de acción de esta práctica:

1. Reproducción como proceso intermedio en la creación de una obra escultórica: cuando se traslada el modelo a su soporte definitivo;

2. Reproducción con el fin de seriar una obra (por lo general en bronce, pero se utilizan también otros soportes);

\footnotetext{
72 Aguilar Galea, José Antonio, Métodos y técnicas de reproducción artísticas aplicadas a la conservación y difusión del patrimonio escultórico, en Actas del I Congreso Internacional Patrimonio, Desarrollo Rural y Turismo en el siglo XXI, Osuna,2004.

http://www.euosuna.org/imasd/proyectos/congresos/noticias/Ponencias\%20Patrimoni ०\%20DEF\%20PDF/PDF/18.pdf
} 
3. Reproducción como herramienta para la reconstrucción de fragmentos o pérdidas de obra artística.

Ya en la Antigüedad lo que motivó la búsqueda de un proceso que permitiese la copia de obras fue el deseo de seriarlas. Así nació el molde. En la Grecia clásica hallará su apogeo esta técnica en la forma de molde de yeso a piezas, modalidad que permite la reproducción de un mismo modelo en diferentes soportes. Esta técnica se mantiene vigente aún hoy, cuando han pasado miles de años desde su creación, lo que demuestra su excelencia. Permitió además el desarrollo de la fundición y la apertura de nuevas posibilidades de expresión en la escultura, ya que el metal permite mayor libertad de acción dada su resistencia, y no limita estructuralmente la composición al problema del soporte, como ocurre con el mármol y cualquier otra piedra. Ya para el siglo XIX los escultores, Rodin por caso, se dedicaban exclusivamente a modelar y dejaban la ejecución de la pieza final en manos bien de sacadores de puntos, bien de fundidores profesionales. Aguilar Galea destaca la división entre moldes rígidos y moldes elásticos. Dentro de los primeros encontramos los de molde perdido, realizados en yeso, que solo permiten una copia, y el molde de yeso a piezas, que posibilita su utilización para obtener varias reproducciones; los segundos son derivados de la industria del petróleo (elastómeros de silicona, látex), gelatina y cauchos. Los moldes de silicona tienen la ventaja, en restauración, de que no dañan el original. 
Lo que interesa a los efectos del presente trabajo son las posibilidades que brindan estos procedimientos de copiado, $\mathrm{y}$ que ayudan a la conservación, la restauración y la difusión del patrimonio artístico. Obras ubicadas en espacios externos y expuestas a la polución ambiental encuentran en la copia la posibilidad de reemplazo de su sitio original y ven así abierta la oportunidad de preservarse en espacios cerrados, piezas deterioradas en mayor o menor medida pueden con la copia mostrar su forma original y, como producto de estas dos vertientes, se enriquecen así los fondos tanto de los museos como de las exposiciones itinerantes, cerrando un círculo virtuoso que redunda en altos beneficios. Para el autor español, el tipo de acciones que propicia la reproducción en los tres sectores permite:

- La conservación en los lugares de procedencia de los originales;

- Una mejor preservación de las obras;

- Prevención de daños en las piezas por la manipulación de terceros en desplazamientos, etc.;

- Garantizar frente a incontinencias (robos, deterioros o alteraciones propias, etc.) el testimonio histórico material de estas piezas; 
- Posibilidad de ceder a museos o exposiciones eventuales estas reproducciones o, en su defecto, si viajan los originales mantener los contenidos expositivos del museo exhibiendo estas réplicas;

- Donaciones de particulares a museos a cambio de reproducciones de las piezas (en contrapartida o como parte del intercambio);

- La posibilidad de comercialización de reproducciones de estas piezas.

Además de los métodos tradicionales de copiado basados sobre el molde, las nuevas tecnologias informáticas han abierto todo un universo en el campo de las reproducciones, y hoy en día hasta llevan la delantera a la hora de decantarse por un método de reproducción dada la tremenda ventaja que aportan al no tener que realizar un contacto directo o invasivo con la superficie o el cuerpo de la obra para poder reproducirla. Estas tecnologías informáticas de última generación no sólo permiten copias veloces y prácticamente perfectas -en la escala que se quiera-, sino que además no afectan en absoluto, merced a la posibilidad que brinda el escáner, el estado de la obra original.

Los usos y aplicaciones que brindan estas tecnologías son infinitos. No sólo ayudan a la reproducción, sino que 
posibilitan acceder a información sobre los originales que antes hubiera sido impensable obtener. $\mathrm{Y}$ todo esto sin arriesgar, como se dijo, a la pieza artística.

El gran avance que posibilitó esta evolución se ha debido a los programas de tratamiento de superficies $3 \mathrm{D}$, dado que en sus últimas versiones, y gracias a la potencia de procesamiento de datos de los ordenadores actuales, se ha logrado procesar con gran fidelidad superficies no analíticas o "complejas", tal como los rasgos de la anatomía humana $u$ otras morfologías naturales.

El primer paso de estos métodos digitales consiste en la obtención de datos de la forma de la obra original tridimensional -una maqueta o prototipo, una obra, un patrón o un modelo natural- mediante el escaneo, y realizar así su digitalización tridimensional, para después guardar esta información en soportes de ficheros tipo CAD, CAE o CAM. A partir de allí se puede elegir si usar esos datos para realizar efectivamente una reproducción material, o almacenarlos en un banco de imágenes para su posterior uso y consulta siempre que se lo requiera y de manera automática $y$ accesible. Dicho proceso de obtención de datos mediante escaneo se denomina técnicamente ingeniería inversa.

Al ser el escaneo la fase crítica del proceso, dado que consiste ni más ni menos que en la producción e ingreso de datos sobre los que se trabajará posteriormente, es fundamental analizar las necesidades particulares de cada caso, ya que no hay soluciones determinadas de antemano (cada obra presenta su 
casuística propia), y por lo tanto se deben tener en cuenta, a fin de realizar una elección correcta, los siguientes factores:

- Geometría: las singularidades de la superficie del modelo y los ángulos de incidencia determinados por su forma determinarán qué tipo de escáner es el más adecuado para realizar el trabajo

- Precisión: el grado de resolución que se pretenda para el modelo 3D incidirá en la elección del escáner. A mayor precisión requerida, más apto deberá ser el sensor utilizado para capturar el mayor número de puntos y así enviar una información más detallada al programa informático.

- Contexto: debe estudiarse el lugar donde está emplazado el original, ya que su ubicación y posibilidades de movilidad establecerán los límites de manipulación y contacto con el mismo.

- Usos futuros del archivo: a fin de optimizar los recursos técnicos y humanos y el tiempo de trabajo, hay que definir el tipo de utilización que tendrá la información por capturar, ya que no es lo mismo realizar una infografia virtual que la reproducción mecanizada del modelo ${ }^{73}$.

73 Fuente: Martínez Torán, Manuel; Pérez García, María del Carmen; Martínez Lázaro, Isabel; Boix Doménech, Miguel, Obtención de modelos digitales a través de técnicas de escaneado y reconstrucción $3 D$ aplicadas a la restauración y conservación: reflexiones sobre la reproducción de duplicados y réplicas escultóricas. En: Actas del $17^{\text {th }}$ International Meeting on Heritage Conservation. VilaReal, Burriana y Castellón, UPV, 2008, pp. 221-226. 
Un buen ejemplo de las técnicas y materiales utilizados en el proceso de reproducción 3D con tecnologías digitales lo hallamos en el desarrollado por la empresa Decó Escultura74, el cual nos servirá de síntesis ilustrativa y puede esquematizarse de la siguiente manera:

1. Digitalización y preparación para el seccionado: mediante una digitalizadora $3 \mathrm{D}$, se convierte el modelo físico en virtual; el resultado es una malla con millones de polígonos. Para realizar este proceso, el modelo no sufre ninguna alteración, ya que fisicamente no se ha tocado (esto lo convierte en un sistema ideal en el campo de la rehabilitación o para hacer réplicas de piezas de gran valor).

2. Maquetado: se cortan las secciones reales de poliestireno expandido ya a la escala final que se desee, luego se unen las secciones y se logra así el volumen definitivo con una forma escalonada; este volumen puede ser en su estructura interna sólido o hueco, de acuerdo con el uso que vaya a darse a la copia y la duración que se quiere tenga la misma; se procederá después al cortado de excedentes de poliestireno con plotter térmico para darle la forma definitiva;

\footnotetext{
${ }^{74}$ http://www.pavimentosonline.com/deco_escultura/escultura.htm
} 
3. Soluciones estructurales: cuando la copia vaya a ubicarse en el exterior, se recomienda sustentar la pieza mediante el cálculo de las cargas (que podrán ser metálicas o de hormigón armado) que se unirán a la piel exterior, de mortero de cemento tixotrópico proyectado dando lugar a una piel de entre 5 y $10 \mathrm{Cm}$. y con su armado correspondiente (normalmente una malla de $15 \times 15 \times 6 \mathrm{~mm})$. Así se obtienen piezas muy resistentes en las que el cuerpo de poliestireno pasa a ser sólo un encofrado perdido.

4. Acabados: hay una gama enorme. Los que suelen utilizarse con más asiduidad son las pinturas al acrilato, las pinturas al silicato, el estuco a la cal, el revestimiento de cuarzo, el revoco de piedra proyectada, el trencadís, etc. El pintado artístico queda a cargo, cuando fuere oportuno $y$ necesario, de especialistas en dicha materia.

Fig. 155. Ejemplo de la reproducción virtual de una escultura por la empresa Deco Escultura.

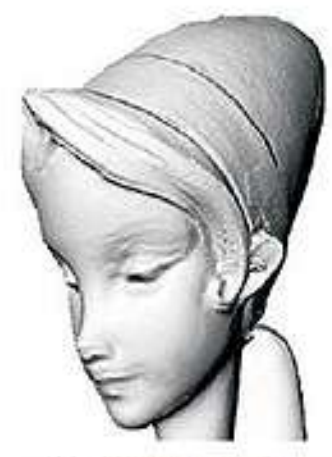

fig2 digitalizacion

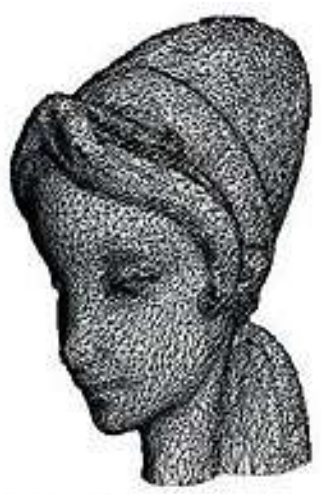

Fig 3 MALLA 30

Fuente: http://www.pavimentosonline.com/deco_escultura/escultura.htm 
Estos métodos de reproducción, tanto los tradicionales como los informáticos, deben combinarse a nuestro entender en la preservación, difusión y restauración del patrimonio cultural de El Tajín. La forma tradicional, basada sobre los moldes, permite generar toda una escuela local de artesanos dedicados a esa tarea, lo que garantiza, junto con las reproducciones eminentemente artesanales que pudieran también hacerse de utensilios, maquetas y otros objetos manuales, la continuidad de las antiguas técnicas y la generación de verdaderos talleres de copia, con maestros y discípulos.

El problema del contacto con el original para la copia, la dificil accesibilidad a una obra o detalle arquitectónico, la necesidad de su reconstrucción o copia precisa, a efectos de exposiciones itinerantes o muestras, hace que los métodos de copia informática basados en tecnologías 3D tengan absoluta validez dentro de las politicas de acción referidas al patrimonio por preservar en El Tajín. Esto llevará a la creación de otro grupo humano especializado, cuya tarea será absolutamente complementaria a la del grupo anterior, y permitirá la apertura y el crecimiento de un banco de imágenes y modelos tridimensionales digitales de acceso sin restricciones, dado que sería factible su consulta a través de Internet desde cualquier punto del mundo, garantizando así la plena difusión global de la riqueza cultural que ha legado esa cultura. 
Como se vió en el apartado 8.2, el hecho de encontrar las claves semióticas y sintácticas, hasta ahora perdidas del lenguaje visual de El Tajín, sería de una importancia trascendental para avanzar en las diferentes áreas de investigación. Tanto los bajorrelieves escultóricos que se encuentran en las canchas de Juego de Pelota Norte y el Juego de pelota Sur, como los que se pueden observar en el Edificio de las Columnas del área de El Tajín Chico -citando los ejemplos más emblemáticos-, debieran ser tratados con técnicas de escaneado 3D a fin de construir modelos virtuales y, llegado el caso, realizar reproducciones exactas a partir de esos modelos, para facilitar la tarea a los estudiosos interesados en desentrañar la hermenéutica de los símbolos inscritos en esas obras. La cuestión de los costos operativos y de equipamiento debe sopesarse no únicamente en función del gasto económico que representaría, sino también de los inmensos beneficios que arrojaría no sólo en el corto plazo, sino, asimismo, en el mediano y en el largo.

Alcanzar las claves que rigen la organización del lenguaje visual de El Tajín ayudaría a conocer las reglas de su distribución, los contextos en que se desarrolla, la composición correcta de todos los elementos involucrados, y posibilitaría una acertada aproximación al formato, la escala, proporción, relaciones geométricas y demás características plásticas y formales en aquellos casos en que sea necesaria la restauración de partes o fragmentos destruidos. 


\subsection{Permanencia e influencia de la obra artística de E1 Tajin en el arte contemporáneo.}

Es tarea imposible cuantificar la influencia de una obra artística como la de la cultura de El Tajín; sin embargo, pueden aducirse ejemplos acabados que demuestren la actualidad y la vitalidad que su temática y su estética tienen en el arte contemporáneo.

Como muestra de vigencia temática, el más acabado es el de la obra del gran pintor y muralista mexicano Diego Rivera (18861957). En su dilatada y prolífica trayectoria destaca su búsqueda permanente de las raíces originarias mexicanas, y el tiempo de estudio y de reflexión que dedicó a dicha tarea y a su resolución plástica y estética a lo largo de su vida.

En el período entre los años 1942 a 1951, Rivera desarrolló múltiples actividades paralelas y complementarias en plena madurez creativa: la Academia de Arte la Esmeralda lo contrató como docente, labor en la que asumió una intensa renovación del plan de estudios, para adecuarlo a las tendencias artísticas contemporáneas; pintó la serie dedicada a la Erupción del volcán Paricutín, en Michoacán, y el notable óleo Día de muertos, entre otros. En 1947, después de recuperarse de una pulmonía, retomó el trabajo de la secuencia histórica que va de la conquista española a la Revolución Mexicana de 1910 en el Sueño de una tarde de domingo en la Alameda, mural situado en el vestíbulo principal del Hotel del Prado, edificio que, luego del terremoto de 1985, 
sufrió daños estructurales irreparables y lamentablemente debió ser demolido.

Es en ese contexto de producción que Rivera encaró la realización de 11 paneles destinados a emplazarse en el piso superior del Palacio Nacional, agrupados bajo el título de México prehispánico y colonial. Documentándose en los códices precoloniales, repasó nuevamente la historia mexicana para preparar de manera adecuada su tema eminente: las culturas prehispánicas. El resultado final, en esta fase, si se lo compara con el realizado en la escalera del mismo edificio, arrojó un estilo más unitario con una marcada influencia de Paul Gauguin, ya que Rivera exhibe, idealizada, como hiciera el francés en sus pinturas de tema polinesio, la vida de los pueblos originarios.

Entre esos 11 paneles se haya La civilización totonaca, del año 1950, mural de 4.92 × $5.27 \mathrm{~m}$. En primer plano se ve una transacción comercial entre los nobles totonacas y los mercaderes aztecas, todos ellos secundados por la presencia de sus dioses protectores. En segundo plano, y como fondo de esta escena, se aprecia la gran pirámide de la ciudad reconstruida de El Tajín; a la izquierda de la obra es posible distinguir un ritual de juego de pelota que se desarrolla en presencia del emperador, mientras que, en el centro, los voladores ejecutan una danza dando vueltas y sujetos boca abajo $^{75}$.

${ }^{75}$ Fuente: AA. VV., Genios del Arte. Diego Rivera. México, Instituto Nacional de Bellas Artes y Literatura, 2004, pp. 80-85. 
Fig. 156. Detalle de La civilización totonaca. 1950. Palacio Nacional, Ciudad de México.

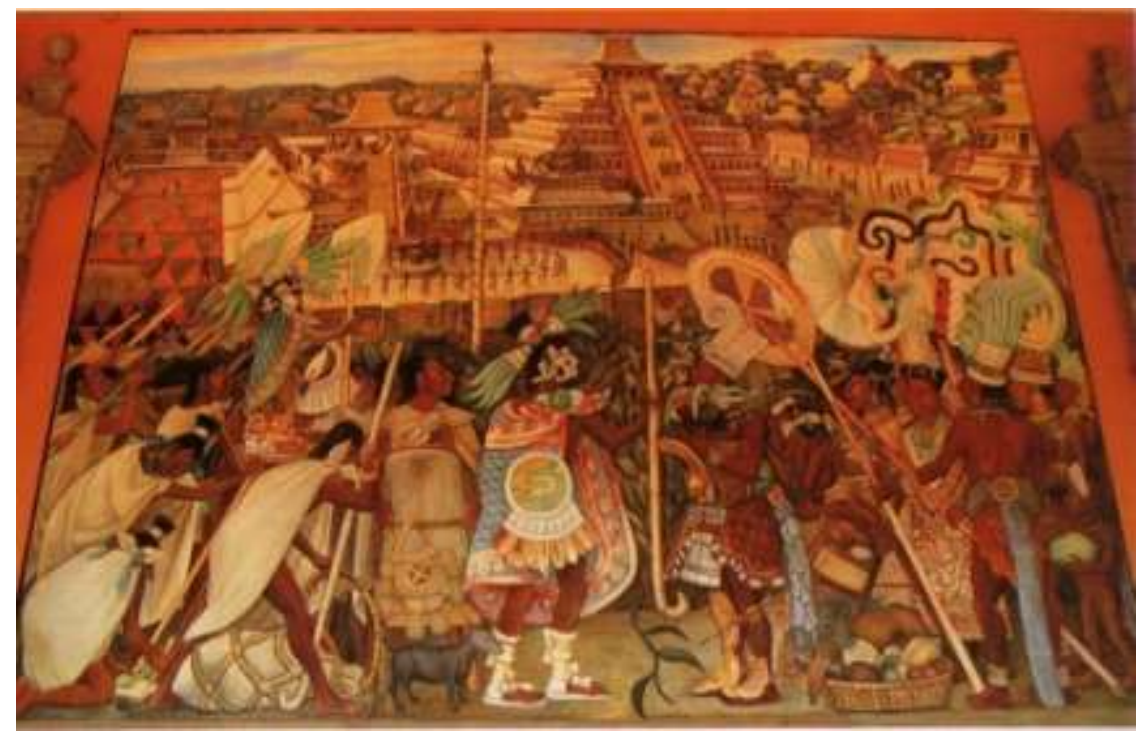

Fuente: Genios del Arte, Diego Rivera

En lo que respecta a la presencia específica de los materiales y la estética de la cultura de El Tajín en obras de arte contemporáneo, un ejemplo claro de aproximación es la producción del Proyecto Tiyat (tierra en totonaco), enmarcado en las actividades permanentes del Parque Temático Takilhsukut y en el encuentro anual Cumbre Tajín. ${ }^{76}$

El Parque Temático Takilhsukut está ubicado en el estado de Veracruz, a $15 \mathrm{~km}$. de Papantla, a $30 \mathrm{~km}$ de la ciudad de Poza Rica y a $1 \mathrm{~km}$ de la zona arqueológica de El Tajín. Su superficie total es de 17 hectáreas; posee una infraestructura con capacidad para 40,000 personas en diversos espacios con todos los servicios. Alberga, además de a la ya dicha Cumbre

${ }^{76}$ Fuentes: http://www.cumbretajin.com ; http://www.soytiyat.blogspot.com 
Tajín, al Centro de las Artes Indígenas, al Consejo Supremo Totonaca, a Kani Tajin (Festival de los Niños), al Aula Clavijero (espacio de educación superior, que recibe entre 100 y 150 estudiantes cada cuatrimestre) y a los campamentos de verano que se realizan cada año.

Según sus mentores, en este parque se impulsa un proyecto educativo que tiene, entre sus ejes, la investigación, experimentación y creación, a fin de que el espectador pueda revalorar las artes indígenas; por ello, se plantea, entre las políticas de acción, un método de trabajo que conjuga la investigación de las culturas de El Tajín y la totonaca, la tentativa plástica en el área tridimensional, integrando al medio ambiente y la práctica del arte contemporáneo. Así, se privilegia el intercambio con los creadores indígenas del Totonacapan, y con toda persona que aporte saberes propios de las culturas ancestrales de la región (artesanos, músicos, danzantes, médicos tradicionales, rezanderos, etc.).

Las obras que resultan de estas experiencias se emplazan luego en las áreas verdes del parque; sus materiales son los propios de la cultura totonaca, y en ellas se puede apreciar la fructífera evolución dinámica que produce la fusión entre los supuestos de las estéticas contemporáneas y las técnicas ancestrales. Un ejemplo lo da la obra de Sergio García, nieto de don Mauricio García, artesano totonaco que descuella en el tejido de sillas de palma: en su pieza Isdakulugua (Serpiente de Estrellas), Sergio da un nuevo uso al asiento de las sillas, y crea así, con materiales y técnicas atávicas, una instalación 
que encaja perfectamente en los lenguajes del arte contemporáneo.

Los creadores participantes del Proyecto Tiyat proceden de Chumatlán, Poza Rica, Coatzintla, Gutiérrez Zamora y Papantla, todas poblaciones cercanas; utilizan bambú, velas, carrizo, madera, paja, etc., y la manera principal en que resuelven formalmente la amalgama técnica, estética y de materiales en sus obras es la instalación. El historiador de arte Luis Josué Martínez Rodríguez, en su presentación de la puesta del proyecto en 2007, señala las coordenadas precisas que acotan con precisión y coherencia la búsqueda del Proyecto, y los motivos de la elección de dicha solución formal:

La cultura se mueve, cambia, se transforma a cada hora, pero también permanece en el recuerdo, en la memoria de la palabra y de los objetos culturales. Entre la palabra y los objetos se construye la identidad de cada persona y, así, la identidad de cada pueblo. (El resultado es siempre producto de un proceso dialéctico, y) para establecer este diálogo se debe establecer un código en común, pero este código debe ir más allá de la lengua, pues entre totonaco y español la complejidad de la traducción puede repeler la comunicación; por tanto, el código debe ser más abierto, entregado a la riqueza cultural. Dicho código será la instalación, 
lenguaje del arte contemporáneo occidental que se encuentra en el umbral de la escultura y la pintura, de la experiencia sensorial y conceptual. La instalación como lenguaje permite al creador conformar un espacio abierto al juego libre y espontáneo con el espectador, proporciona la experiencia vívida de la obra de arte, además de que se sitúa en un ambiente determinado para otorgarle un acento de significancia al mismo ambiente. El espacio es el mismo pero con la instalación dice algo más, y ese algo es la pregunta que cada espectador tiene que descifrar.

(...) Para establecer un diálogo, además del lenguaje, se debe establecer un canal, el espacio donde se transmitirá el lenguaje. El canal en los creadores del Totonacapan será la tierra. (...) En la tierra, la instalación hablará, ahí se propiciará la anhelante comprensión cultural. Tanto creadores como espectadores entenderán las grietas de la piel, las arrugas de la piedra. Se crearán espacios metafóricos y alegóricos donde la cultura totonaca, la presente y la pasada, cobrará fuerza, se mostrará en un imponente diálogo 77 .

\footnotetext{
${ }^{77}$ Fuente: http://www.soytiyat.blogspot.com
} 
Fig. 157. Obra Kgakilhtamakú (La bóveda celeste) de Beatriz Leal. Instalación orgánica en Cumbre Tajín 2007, Papantla, Veracruz. México.

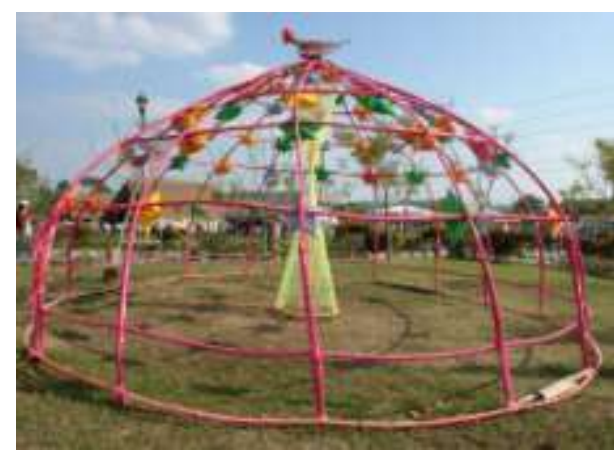

.Fuente: http://www.soytiyat.blogspot.com

No se puede dejar de señalar para concluir que, si bien las actividades del Parque Temático Takilhsukut y del evento anual Cumbre Tajín permiten exhibir de modo permanente el invalorable legado artístico de la cultura de El Tajín y de la totonaca, difundiendo así el patrimonio y haciendo esta tarea sustentable, ya que genera recursos económicos, educativos, artísticos, turísticos, etc., hay quienes se oponen a estas actividades, afirmando que la zona arqueológica sufre daños importantes por la gran y descontrolada afluencia de visitantes, lo que daña poco a poco, pero inevitablemente, la integridad de las construcciones conservadas, amén de que al tratarse de una iniciativa de capitales privados la ganancia monetaria producida no queda en manos de los pobladores, sino de empresas provenientes de fuera de la zona. 


\section{CONCLUSIONES Y REFLEXIONES FINALES.}

El análisis del lenguaje visual que se ha venido exponiendo en este trabajo sobre los casos de estudio de la arquitecturaescultura de El Tajin, habiendo hecho previamente un recorrido contextual y de los posibles antecedentes históricos y artísticos de su cultura, ha aportado que existen elementos configuradores dentro de la morfología que no pueden comprenderse fuera de una estructura que le da fuerza y vitalidad.

Se ha iniciado separando estos elementos significativos e individuales: el nicho-cornisa volada, la greca escalonada, los rombos, la cruz, con todas sus variantes formales; cada uno representa la expresión mínima formal y simbólica que adquieren significación formando parte del esquema arquitectónico talud-tablero de herencia teotihuacana. Dentro de este sistema rector existieron diferentes composiciones propositivas de cada región cultural, dando lugar a la diversidad estética y plástica.

El Tajin destaca principalmente por aportar un elemento formal no utilizado por otras culturas mesoamericanas: el nicho, que es visible en todos los edificios de manera constante y dinámica; con sus variaciones formales y compositivas, tantas como edificaciones existentes en la zona, que provocan en el observador la acentuación y distinción simbólica, a la vez que plástica. 
E1 nicho es recurrente, $y$ al ser una constante formal, se vislumbra como representante de un concepto integrador de la arquitectura de este lugar. El nicho/cornisa volada, otorgan a las construcciones cualidades plásticas que podrian estar relacionadas con su interpretación simbólica: la forma es a la función.

El deseo vehemente de sus constructores de otorgar a la piedra, perene y sólida, la sensación de ligereza así como de infundirle dinamismo, es producto de una composición rítmica al utilizar la repetición modular (el nicho como módulo) distribuida en secuencia horizontal y vertical, ascendente/descendente propiciando el seguimiento visual continuo. El "movimiento virtual" consecuente, estaria relacionado con la deidad suprema Tajín (Tlaloc para los teotihuacanos) que simboliza el Rayo o Trueno Viejo, según los pobladores actuales, también relacionada con las tormentas y huracanes. Esta sensación experimentada se acrecienta, por el contraste de luces y sombras provocadas naturalmente por el sol que ilumina los edificios durante las diferentes horas del día, incidiendo en los huecos más o menos profundos de sus nichos. Ello revela la importancia que tenía para los habitantes de El Tajín, sin importar el material utilizado, lograr la comprensión de que nada permanece estático ni imperturbable, siendo el "movimiento" una cualidad vital del lenguaje visual de su arquitectura-escultura. Es en el Edificio 1 o Pirámide de los Nichos en donde se captura mejor esta sensación. 
El nicho interacciona también con otras formas, que de manera ingeniosa $y$ finamente detallada se añaden armónicamente a su estructura. Se trata de la greca escalonada, que fue ampliamente conocida y utilizada tanto en Mesoamérica como en otras antiguas culturas en el mundo. Se emplea la composición de la greca en simetría radial y axial siguiendo la rigurosa geometría abstracta del nicho, y se percibe como si ocupara el espacio vacío dentro de este; ello es debido al trabajo cuidadoso que se tuvo en su construcción, cuya finalidad es indudablemente lograr esta apreciación, en congruencia con el diseño general de colocar nichos o "falsos nichos" en los edificios.

El nicho, como elemento de identidad formal en El Tajín, adquiere además un nuevo aspecto visual, ganando en mayor peso y atracción, así como se potencia la tensión dinámica de sus partes, configuradas modularmente junto con la greca escalonada y en sucesión continua, sumando por consecuencia una apariencia más compleja cargada de contenidos simbólicos-mágicos, ${ }^{78}$ que van aumentando conforme el edificio se satura de ellos.

Por consiguiente, tenemos la siguiente relación: a mayor complejidad formal en la composición arquitectónicaescultórica, se añade un status mayor al templo, pirámide o palacio dentro de la organización del poder social, religioso,

\footnotetext{
${ }^{78}$ La greca escalonada en simetría radial se utilizó en El Tajín, cuya imagen es similar a la llamada cruz en movimiento, de la cual se han hecho comentarios relacionándola con la swástica por su similitud formal. Además de su plasticidad y dinamismo tiene connotaciones altamente simbólicas, místicas y esotéricas.
} 
sacerdotal del sitio. Algunas de las construcciones con estas características, como por ejemplo el Edificio A, C y el Complejo de las Columnas, están localizadas principalmente en el área de acceso más restringido y en nivel de altitud mayor construido para albergar los edificios de esta zona.

Dentro de estas consideraciones se encuentran también los Juegos de Pelota Norte y principalmente el Juego de Pelota Sur, siendo de los 17 hasta ahora localizados, los más importantes y relevantes del sitio, por contener en sus muros los bajorrelieves analizados en el Tema 7, destacando su estilo de representación característico: el estilo clásico veracruzano o estilo Tajin.

Los tableros centrales del Juego de Pelota Sur son los más saturados visualmente, resultando complejos y de dificil lectura cuando se observan por vez primera. Sin embargo, a través del estudio morfológico, geométrico, icónico, identificando patrones de repetición o constantes, etc., se van reconociendo con mayor claridad sus elementos formales, organizados y distribuidos dentro de un esquema compositivo que estuvo previamente planificado.

Es interesante hacer notar que, asî como se ha puntualizado en la cualidad y sensación del "movimiento" latente mayor o menormente en las construcciones, aparece también con frecuencia representado en las escenas de los tableros en bajorrelieve, el signo de ollin (vocablo de origen náhuatl que significa: “movimiento"). Se refuerza paralelamente este 
concepto primordial dentro del pensamiento mesoamericano, ahora utilizando el recurso de representación gráfica y simbólica.

La figura tan característica de El Tajín, la greca escalonada como unidad formal, presenta también cualidades dinámicas por sí misma. La greca escalonada en simetría radial está vinculada con la cruz y los rombos entrecruzados, ya que presentan 4 puntos o espacios que resultan de la intersección del eje horizontal con el eje vertical; es posible identificar con claridad lo anterior, solo con la observación visual reflexiva y atenta.
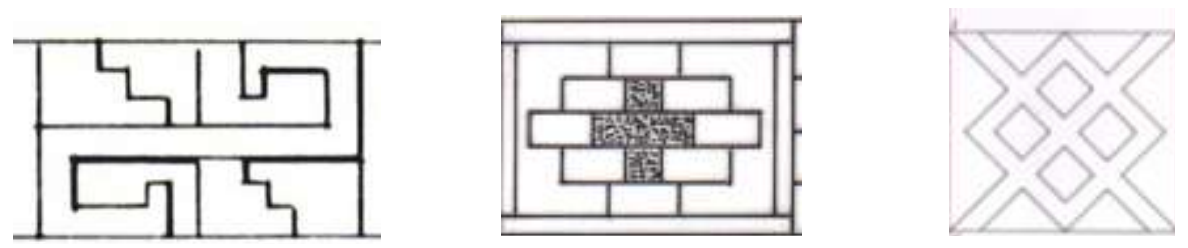

Estableciendo sus similitudes y variables morfológicas cada una expresa en esencia un ordenamiento geométrico muy similar, pero en contextos diferentes. La técnica visual de repetición modular en secuencia horizontal es la utilizada preferentemente en estos tres casos visible en fachada, remate y primer cuerpo o basamento de los edificios que las contienen; es decir, funcionan como unidades visuales simbólicas rítmicas y dinámicas. 
El movimiento, como cualidad añadida, inherente de las formas utilizadas, es entonces un concepto recurrente en el lenguaje visual de la arquitectura-escultura de El Tajín. Ha logrado hacerse sensible a través de la psicología de la percepción que nuestra visión utiliza como un mero acto fisiológico, de acuerdo a los estudios de la Gestalt; para el ojo, los opuestos se repelen y las formas semejantes se atraen. Por asociación y agrupamiento de objetos similares, la vista da continuidad a la sucesión modular, originando el avance virtual de formas, el cual experimentamos como una sensación dinámica de percepción meramente visual, tal como si fuera un juego o engaño a para los ojos.

Todos estos elementos mencionados forman parte de un sistema organizador compositivo, sometido a una geometría rigurosa y sin el cual es dificil lograr estas percepciones.

Se ha hecho un análisis formal de los edificios de El Tajín casos de estudio ${ }^{79}$, pertenecientes a los principales espacios urbanos. Es oportuno hacer hincapié en que estos edificios, en su mayoría, desarrollan el espacio exterior sobre el interior, ya que son estructuras en masa (basamentos piramidales), cuya función tenía relación con actividades rituales; las fachadas y sus laterales comprenden la superficie exterior, que viene a representar lo más importante así como su totalidad formal de

79 Los edificios estudiados son: Los 4 basamentos piramidales de la Plaza del Arroyo, la Pirámide de los Nichos, Edificio 3 y 5, Edificio A y C de Tajín Chico y Edificio 42 también conocido como Edificio de las Columnas. 
expresión plástica y espacial. Están mayormente en relación con la geografia natural circundante formando parte del paisaje de manera integral y armónica, así como del urbanismo de la ciudad. Este comprende, entre otras cosas, plazas delimitadas por las mismas construcciones dando lugar a zonas para llevar a cabo diversas actividades.

En la primera fase urbana histórica se encuentra la gran plaza pública formada por 4 edificaciones (Plaza del Arroyo) y conforme va desarrollándose la ciudad, poco a poco el espacio va estrechándose; la Pirámide de los Nichos, el Edificio 3, 4 y 5 forman parte de una plaza central más reducida, y en la zona de El Tajín Chico los edificios A, B y C forman una pequeña plaza interior. En la zona más alta del sitio, conocida como acrópolis, el Edificio de las Columnas estuvo circundado por otras edificaciones conformando un espacio o plaza cerrada alrededor de los mismos.

Cada una de las construcciones, caso de estudio, tiene características formales únicas e individuales, pero siempre conservando el estilo arquitectónico de El Tajín, es decir, todas presentan el nicho-cornisa ya sea estructuralmente o utilizando juegos de macizos de nichos. Es clara la intención de que no hubiese duplicados compositivos en todo el sitio; sin embargo, hay ciertas semejanzas obvias en la morfología de algunos, que no pasan desapercibidas y que bien pudieron responder a una necesidad de relación funcional, ritual, simbólica, etc. El Edificio 18 y el 20, que se sitúan uno frente al otro en la Plaza del Arroyo, presentan puntos de 
coincidencia formal en: altura y proporción, número de escalinatas centrales y número de macizos de nichos de sus fachadas. Su apariencia es muy similar, pero no idéntica.

Otro caso muy notorio es el Edificio 3 con el 23, que por encontrarse en estrecha colindancia, así como por su altura, diseño y proporción parecen hermanarse formalmente, aunque presentan algunas variantes en las escalinatas centrales y en los cuerpos piramidales. Podría afirmarse con toda certeza que a la vista son gemelos, y así se han considerado; desde el punto de vista formal se conoce que, aunque por su enorme parecido morfológico se vean iguales, cambian sus fachadas y detalles de sus cuerpos.

Existen ejemplos claros de pirámides idénticas en Mesoamérica, como en Mixco Viejo, en Guatemala, en el complejo de pirámides gemelas de Tikal; en el sitio de Yohualichan, Puebla, que tiene nexos evidentes con la arquitectura con nichos y cornisas de El Tajin, también tiene pirámides gemelas.

Con seguridad es muy probable que se tuviera toda la intencionalidad al identificar estas construcciones de El Tajín como similares o "gemelas" debido a su gran parecido formal, además de estar asociadas a las funciones que pudieron desempeñar tanto prácticas como rituales-simbólicas.

Un elemento de gran importancia en la composición formal de los edificios, son las escalinatas centrales de sus fachadas. En 
los Edificios del Grupo del Arroyo, la Pirámide de los Nichos, el Edificio 5 y 3 , se tiene que, el punto de interés visual se concentra en el binomio compositivo de escalinatas/alfardas.

La escalinata, además de ser un elemento funcional indispensable para la accesibilidad a los templos superiores, así como para la resistencia estructural del edificio, desempeñándose como contrafuerte, presenta variables de anchura y proporción junto con las alfardas, provocando juegos visuales rítmicos y en calidad de imprimir "textura" a la superficie exterior.

Debido a su naturaleza sólida, la alfarda80 tiene mayor peso en la composición en cuanto más anchura tenga, como en el caso de la alfarda central del Edificio 16. En la Plaza del Arroyo, es posible notar que todas las alfardas laterales de las fachadas guardan una proporción similar con la intención de tener más elementos en relación, equilibrando la anchura con respecto a las escalinatas. Esta es una de las razones, además de su alineación geométrica y coincidencias formales ${ }^{81}$, por la que los edificios de esta plaza se aprecien de forma integral $y$ armoniosa.

La alfarda también se aprovecha para colocar en ella elementos simbólicos, como en el caso de La Pirámide de los Nichos, cuyas alfardas laterales llevan en bajorrelieve la greca

\footnotetext{
${ }^{80}$ Las alfardas varían en anchura y eran construidas un poco más elevadas que la escalinata. Eran elementos de protección y añaden al edificio mayor impacto y prestigio visual.

${ }^{81}$ Es el caso de colocar macizos de nichos en todas las escalinatas centrales de los 4 basamentos piramidales que conforman la Plaza del Arroyo.
} 
escalonada en dirección ascendente o, en el acceso principal al Edificio A, con grecas en sus alfardas. Generalmente, las alfardas están rematadas, una o varias veces, con un nicho/cornisa volada del ancho de la misma, marcando límites dentro de la morfología compositiva, por ejemplo en basamentos, final de escalinatas, niveles estructurales, etc. Esto es más frecuente en la Fase II y III.

En las escalinatas no pasan desapercibidos los macizos de nichos con greca o sin ella y que varían en número $\mathrm{y}$ distribución.

Los juegos de macizos de nichos representan un recurso formal de interés focal de gran importancia, por su peso, proporción y disposición centrada a lo largo y ancho de las escalinatas preferentemente, aunque también aparecen en las alfardas de los edificios; sugiere nexos simbólicos, posiblemente por el número de nichos utilizado en cada macizo, variable en cada caso estudiado. Su importancia formal radica en que a través de este recurso escultóricoarquitectónico añadido a la construcción, se logra la integración de un lenguaje visual propio y original por tener nichos y, representados de esta manera por esta cultura.

Otra interpretación es la percepción que provoca en el observador este conjunto de formas compositivas (escalinatas/alfardas); un ejemplo es el rompimiento de las secuencias horizontales originadas en los basamentos escalonados con respecto a una verticalidad ascendente. Cabe aquí la reflexión de acercarse a la interpretación con el 
significado que Bruno Zevi otorga a las líneas horizontales, que expresan lo racional e intelectual, en contraposición de la vertical que representa lo infinito. 82

Con referencia al análisis de la geometría compositiva que presentan las fachadas de los casos de estudio, prevalece el Rectángulo Raíz Cuadrada $\left(\boldsymbol{R}^{2}\right)$ como traza mayormente constante; también se emplearon el Rectángulo Áureo y el Rectángulo Raíz Cúbica teniendo como base inicial el Cuadrado Raíz, fundamento mítico, símbolo de los cuatro puntos cardinales.

Las relaciones geométricas se van asociando con las proporciones y escalas de sus elementos formales que los constituyen; así se encuentra que el juego de medidas se repite dentro de la estructura del edificio y que, en algunos casos, los puntos coinciden con partes de importancia focal (anchura de escalinatas, alfardas, macizos de nichos); esto finalmente se transforma en un ordenamiento matemático lógico y organizado.

Todas estas consideraciones formales, realizadas siguiendo la semántica propia del lenguaje visual, dan la certidumbre de complementar los conocimientos que hasta el momento se tienen de este patrimonio cultural en el sitio de El Tajín.

Finalmente es preciso apuntar que, no hay duda alguna que todos los recursos formales y de percepción mencionados,

\footnotetext{
${ }^{82}$ Zevi, Bruno: Saber ver la arquitectura en www.todoarquitectura.com
} 
fueron puestos en función y a disposición de la cosmovisión, pensamiento mítico-religioso, orden y jerarquías sociales, etc., de los constructores de la ciudad de El Tajín. La forma en que se revela la imagen de su arquitectura-escultura es un lenguaje didáctico constante y vibrante, tangible y presente activamente..., visualmente, dejando impresiones sensibles en la memoria cultural que lo hace apreciarlo y valorarlo como un legado histórico-artístico capaz de trascender a su propio destino. A través de indagar en la organización compositiva formal, plástica, estética, se pueden resolver interrogantes de cual fue el patrón distributivo de sus elementos arquitectónicos-escultóricos que percibimos, identificándolos como un lenguaje, un sistema de comunicación visual con sus propias unidades significativas y codificadas, que se configuran siguiendo los conceptos primordiales de una cultura, como en la antigua ciudad de El Tajín.

En la medida que se aporten mayores conocimientos interdisciplinarios sobre este patrimonio universal, se estará dando un paso mas en el terreno de su conservación y futuras intervenciones. 


\section{BIBLIOGRAFIA}

\section{BIBLIOGRAFÍA GENERAL:}

AA.VV. (2001). Descubridores del pasado en Mesoamérica. D.G.E. Ediciones S.A. de C.V./Turner Publicaciones. México.

(1995). Dioses del México antiguo. (Catálogo). Ediciones del Equilibrista S.A. de C.V./Turner Libros S.A. México.

-(1986). Enciclopedia del Arte Mexicano. (Tomo 1 y 2) Salvat Ediciones S.A. México.

-(2004). Genios del Arte. Diego Rivera. Instituto Nacional de Bellas Artes y Literatura. México.

-(2006). Los mayas, una civilización milenaria.

KÖNEMAN. China.

ALCINA FRANCH, J. (1982). Arte y antropología. Alianza Editorial. Madrid.

-(1988). Las claves del arte precolombino. Como identificarlo. Colección Las Claves del Arte. Sorpama S.A. Barcelona.

BARBA DE PIÑA CHAN, B. (2002). Iconografía Mexicana III, la representación de los astros. INAH. México.

CASO, Alfonso. (1974). El pueblo de Sol. FCE. México.

CHAVERO, Alfredo D. (1971). México a través de los siglos. (Tomo 1) Editorial Cumbre S.A. México.

CLAVIJERO, Francisco Javier. (1964). Historia antigua de México. Editorial Porrúa Sepan Cuantos. México. 
COHEN, Josef. (1982). Sensación y percepción visuales. Editorial Trillas. México.

DE LA FUENTE, B. (1977). Los Hombres de Piedra, Escultura Olmeca. UNAM. México.

DE LA FUENTE, B. y Staines Cicero, L. (1988). La pintura mural prehispánica en México Área Maya Bonampak. (Tomo I y II) UNAM Instituto de Investigaciones Estéticas. México.

DÍAZ DEL CASTILLO, Bernal. (2000). Historia verdadera de la conquista de la Nueva España. (Antologia). CONACULTA. México.

DU SOLIER, W. (1950). Indumentaria antigua mexicana. Ediciones Mexicanas. México.

ECO, Humberto. (1990). La definición del arte. Ediciones Martinez Roca. México.

FERNÁNDEZ ARENAS, J. (1999). Introducción a la conservación del patrimonio y técnicas artísticas. Editorial Ariel S.A. Barcelona. España.

FERNÁNDEZ, Justino. (1990). Estética del arte mexicano. Instituto de Investigaciones Estéticas UNAM. México.

FRANKL, Paul. (1981). Principios fundamentales de la historia de la arquitectura. Editorial GG. Barcelona. España.

GARCÍA MÁRQUEZ, A. (2005). Los aztecas en el Centro de Veracruz. UNAM Instituto de Investigaciones Antropológicas:

Programa de Posgrado en Estudios Mesoamericanos. México.

GENDROP, P. (1970). Arte prehispánico en Mesoamérica. Editorial Trillas. México.

GHYKA, Matila C. (1978). El número de oro. Los ritmos. Editorial Poseidón. Barcelona. España. 
-(1977). Estética de las proporciones en la naturaleza y en las artes. Editorial Poseidón. Barcelona. España.

GONZÁlEZ CERECEDO, A. (1999). Ceremonias indigenas de Veracruz. Editora de Gobierno Xalapa. México.

HESSELGREN, Sven. (1973). El lenguaje de la arquitectura. Editorial Universitaria de Buenos Aires. Argentina.

HOLDEN, Alan. (1991). Shapes, space and symmetry. Dover Publication. N.Y. USA.

HUNTLEY, H.E. (1970). The divine proportion: a study on mathematical beauty. Paperback. USA.

KIRCHHOFF, P. (1960). Mesoamérica. Sus limites geográficos, composición étnica y caracteres culturales. Suplemento de la revista Tlatoani: núm. 3. ENAH. México.

KRICKEBERG, W. (1980). Mitos y leyendas de los aztecas, incas, mayas y muiscas. FCE. México.

LADRÓN DE GUEVARA, S. (2007). Hombres y dioses de El Tajin, Las deidades del Tajin. Antropología e Historia en Veracruz, Xalapa: Gobierno del Estado de Veracruz. Instituto de Antropología de la Universidad Veracruzana. México.

LAWLOR, Robert. (1993). Geometría sagrada. Ediciones del Prado. Madrid. España.

LONGHENA, M. (2005). México antiguo. Ediciones Folio S.A. Barcelona. España.

MELGAREJO VIVANCO, J. L. (1984). El códice Coacoatzintlan. Universidad Veracruzana. Instituto de Antropologia Xalapa. Veracruz. México.

-(1984). El Códice Misantla. Universidad Veracruzana, Instituto de Antropologia. Xalapa. Veracruz. México. 
-(1985). Los totonacas y su cultura. Universidad Veracruzana. Xalapa. Veracruz. México.

-(1989). Historia de Cotaxtla. Universidad Veracruzana. Xalapa. Veracruz. México.

MILLER, M. E. (1986). The art of Mesoamerica. From Olmec to Aztec. World of Art. Thames and Hudson. Londres.

MEDELLIN ZENIL, A. (1980). Cerámicas del Totonacapan. Universidad Veracruzana. Xalapa. Veracruz. México.

MÉXICO Splendors of thirty centuries. (1990). Metropolitan Museum of Art. Nueva York. USA.

MORANTE LÓPEZ, F. y Ruiz Zapata, Ana Ma. (1997). Análisis y comentario de la obra de arte. Estudios de obras de pintura, arquitectura y escultura. Editorial Edinumen. Madrid. España.

MORANTE LÓPEZ, R. B. (2000). El universo mesoamericano: conceptos integradores. En Desacatos (núm. 5). Centro de Investigaciones y Estudios Superiores en Antropologia Social. México.

MUÑOZ COSME, G. (2006). Arquitectura Maya. General de Ediciones de Arquitectura. Valencia. España.

OCHOA, L. (1989). Huaxtecos y Totonacos : una antología histórico-cultural. Consejo Nacional para la Cultura y las Artes. México.

PACIOLI, L. (1991). La divina proporción. Akal Ediciones. España.

PANOFSKY, E. (1984). Estudios sobre iconología. Alianza. España.

PASZTORY, E. (1998). Pre-columbian art. Cambridge University. Reino Unido. 
PEDOE, Dan. (1982). La geometria en el arte. Colección Punto y Línea. Editorial Gustavo Gili. Barcelona. España.

PIÑA CHAN, R. (1995). El lenguaje de las piedras. FCE. México. -(1986). Historia, arqueología y arte prehispánico. FCE. México.

RISEBERO, Bill (1995). Historia dibujada de la arquitectura. Celeste Editores. España.

ROIG PICAZO, Pilar. (2006). Estudio técnico, analitico y estilistico de obras de arte. Universidad Politécnica de Valencia. Valencia. España.

ROVIRA MORGADO, R. (1984). Características culturales generales de Mesoamérica. Enciclopedia México y su Historia. México.

RUIZ DE LACANAL, M. D. (1999). El conservador-restaurador de bienes culturales. Editorial Síntesis S.A. Madrid. España.

SÉJOURNÉ, L. (2003). El universo de Quetzalcoatl. Fondo de Cultura Económica. México.

-(2003). Pensamiento y religión en el México antiguo.

Fondo de Cultura Económica. México.

SONDERENGUER, C. (2000). Diseño Precolombino. Catálogo. Gustavo Gili. España.

-(2001). Cerámica Precolombina, Catálogo. Corregidor. Buenos Aires. Argentina.

-(2003). Manual de Diseños Precolombinos. Nobuko. Argentina.

-(2004). América precolombina: sintesis histórica, antología y análisis de su arte plástico. Nobuko. Buenos Aires. Argentina. 
-(2007). Manual de Estética Precolombina. Nobuko. Argentina.

TOSTO, Pablo. (1988). La composición áurea en las artes plásticas. Edicial. Buenos Aires. Argentina.

WeSTHEIM, P. (1985). Arte antiguo de México. Era. México.

-(1972). Ideas fundamentales del arte prehispánico en México. Alianza Editorial Era. México.

-(1977). Obras maestras del México Antiguo. Era. México.

WHITTINGTON E. M. (2001). The Sport of Life and Death: The Mesoamerican Ballgame. Mint Museum of Art in Charlotte NC. USA.

WORRINGER, W. (1986). Abstracción y naturaleza. FCE. México. 


\section{BIBLIOGRAFÍA ESPECÍFICA:}

ACASO, M. (2006). El lenguaje visual. Ediciones Paidós Ibérica S.A. España.

ARNHEIM, R. (1993). Arte y percepción visual. Alianza Editorial S. A. Madrid. España.

-(1960). El pensamiento visual. Eudeba. Argentina.

BERTERLS, U. (1987). La iconografía del Tajín, especialmente las representaciones de los dioses. Proyecto Tajin temporada 1987. Ms. (vol. I) INAH-Universidad Munster. El Tajin. Veracruz. México.

BRÜEGGEMANN, J. K. (1984-1990). Informes técnicos del Proyecto Tajin. Ms. Archivo de Monumentos Prehispánicos. INAH. México.

-(1992). Tajin. Equilibrista-Turner. México.

-(1991). El marco geográfico ambiental. En Brüeggeman (coord.). (1991: 237-275). (tomo I) 1991c.

-(1991). El manejo del material cerámico de superficie dentro y fuera del asentamiento arqueológico del Tajín. En Brüeggemann (coord.) (1991:65-79) t. II. 1991d.

-Análisis urbano del sitio arqueológico del Tajín. En Brüeggemann (coord.) (1991: 81-125) (tomo II) 1991e.

-(1992). El medio geográfico-cultural. En Brüeggemann. 1992a:(15-38) 1992a .

-(1992). La concepción plástica en el arte mesoamericano. En Brüeggemann. (1992:41-52) 1992c.

-(1992). Arquitectura y urbanismo. En Brüeggemann. (1992:55-83) 1992c. 
-(1992). El juego de pelota. En Brüeggemann. (1992:8597) $1992 d$.

-(1992). Introducción. En Brüeggemann et al. (1992:319) 1992e.

-(1992). La ciudad y la sociedad. En Brüeggemann et al. (1992:47-77) 1992f.

-(1992). El juego de pelota. En Brüeggemann. (1992:113-131) 1992g.

CARRASCO HUERTA, R. (2000). Levantamientos topográficos de sitios arqueológicos, área circunvecina Tajin. Tesis Profesional. Universidad Veracruzana, Veracruz. México.

CASTILLO PEÑA, P. (1989). Aspectos iconográficos de Tajín. Tesis Profesional. Universidad Veracruzana. Xalapa. Veracruz. México.

-(1990). Catálogo de escultura de El Tajín. Proyecto Tajin. Informe técnico temporada 1989-1990. Ms. (2 ts.) El Tajín. Veracruz. México.

-(1995). Expresión simbólica del Tajin. Colección Científica 306. Instituto Nacional de Antropologia e Historia. México.

CUEVAS FERNÁNDEZ, H. (1995). El Tajin: estudios monográficos. Universidad Veracruzana. Xalapa. Veracruz. México.

CHING, F. (1995). Arquitectura: forma, espacio y orden. México. Editorial Gustavo Gili. Barcelona. España.

DONDIS, D. A. (1973). La sintaxis de la imagen. Editorial Gustavo Gili. España. 
DU SOLIER, W. (1939). Principales conclusiones obtenidas del estudio de la cerámica arqueológica de El Tajín. Actas del XVII Congreso Internacional de Americanistas. INAH. núm. 2. México.

GARCÍA PAYÓN, J. (1943). Interpretación Cultural de la zona arqueológica del Tajín, seguida del Ensayo de una Bibliografia Antropológica del Totonacapan y Región Sur de Veracruz. UNAM. México.

-(1939-1970). Informes técnicos de las temporadas de campo en El Tajin. Archivo de Arqueología. INAH. México.

-(1951). La Ciudad Arqueológica del Tajín. Universidad Veracruzana. México.

-(1954). El Tajín, descripción y comentarios. Revista de la Universidad Veracruzana. año III. núm. 4. Veracruz. México.

-(1961). Ensayo de una interpretación de los bajorrelieves de los cuatro tableros del Juego de Pelota Sur del Tajín. La Palabra y el Hombre. núm. 26. Xalapa. Veracruz. México.

-(1963). Bibliografía Arqueológica de Veracruz, Cuadernos del Instituto de Antropología. Universidad Veracruzana. Xalapa. Veracruz. México.

-(1965). Archaeology of Central Veracruz, Handbook of Middle American Indians, Vol. II, Archaeology of Northern America. USA.

-(1973). Los enigmas del Tajin. La Ciudad Sagrada de Hurakán, 2 Chacmool en la Apoteosis del Pulque. INAHSEP. México.

-(1976). Guía Oficial del Tajín. INAH. México. 
GARCÍA VEGA, A. (1929-1937). Informes técnicos. INAH. Archivo de Arqueología. México.

KAMPEN MICHAEL, E. (1972). The sculptures of el Tajin Veracruz México. Universidad of Florida Press Gainesville. Florida. USA.

KELLY, Isabel Truesdell. (1952). The Tajin Totonac. United States Government printing office. Washington. USA.

KOONTZ, R. (1994). The Iconography of El Tajin, Vera Cruz, Mexico. Ph.D. dissertation. University of Texas at Austin. Austin. Texas. USA.

KROTSER, R., KROTSER, P. (1973). Topografía y cerámica de El Tajin, Veracruz. Anales del INAH. 1 ${ }^{\mathrm{a}}$. época (vol. III). México.

LADRÓN DE GUEVARA, S. (1999). Imagen y pensamiento en El Tajin. Instituto Nacional de Antropología e Historia. D.F. México.

MACHADO, J. L. (2000). The Structure "I" Murals of El Tajin: Standing at the Edge of the Underworld. Tesis. Universidad de Texas. Austin. Texas. USA.

MÁRQUEZ P.J. (1972). Sobre lo bello en general: $y$, dos monumentos de arquitectura mexicana Tajín y Xochicalco. UNAM. Instituto de Investigaciones Estéticas. México.

MARQUINA, I. (1951). Arquitectura prehispánica. Memorias. INAH. México.

MELGAREJO VIVANCO, J. L. (1974). Los relieves del Juego de Pelota Sur en el Tajin, en La Palabra y el Hombre. Nueva Época. núm. extraordinario (septiembre). UV Xalapa. Veracruz. México.

MELGAREJO VIVANCO, J. L. (1974). Las revelaciones del Tajin. Universidad Veracruzana. Xalapa. Veracruz. México. 
MONTES SERRANO C. (1992). Representación y análisis formal. Secretariado de Publicaciones Universidad de Valladolid. España.

MUNARI, B. (1997). Diseño y comunicación visual. Colección Comunicación visual. Editorial Gustavo Gili. Barcelona. España.

PALACIOS, E. J. y Meyer, E. (1932). La ciudad arqueológica del Tajín. Sus revelaciones. Biblioteca de Estudios Históricos y Arqueológicos Mexicanos. México.

PASCUAL SOTO, A. (1990). Iconografía arqueológica de El Tajín. UNAM Instituto de Investigaciones Estéticas. Fondo de Cultura Económica. México.

-(2003). El arte en tierras de El Tajín. CONACULTA. México.

-(2006). El Tajín. En busca de los origenes de una civilización. UNAM Instituto de Investigaciones Estéticas. CONACULTA INAH. México.

PASO Y TRONCOSO, F. DEL. (1911). Arqueología mexicana. Las ruinas de Cempoala y el templo de El Tajín (estado de Veracruz) exploradas por el director del Museo Nacional de Arqueología, Historia y Etnología en misión en Europa. Anales del Museo Nacional de México. $3^{\circ}$ época (vol. III). México.

PÉREZ MORALES, J. (1999). Las artes plásticas aplicadas a la restauración de la pintura mural prehispánica del edificio I de la zona arqueológica de El Tajín. Memoria-Tesis Facultad de Artes Plásticas. Universidad Veracruzana Xalapa. Veracruz. México.

PESCADOR, Laura. (1992). Los juegos de pelota en El Tajín (Tesis). ENAH. México.

PIÑA CHAN, R. y Castillo Peña, P. (1999). Tajīn, la ciudad del Dios Huracán. Fondo de Cultura Económica. México. 
PROSKOURIAKOFF, T. (1951). Scroll Patterns of Veracruz. Revista Mexicana de Estudios Antropológicos 13. México.

-(1952). Varieties of Classic Central Veracruz Sculpture. Contributions of the Carnegie Institution of Washington. No.58. Washington. D.C. USA.

-(1971). Classic Art of Central Veracruz. Handbook of Middle American Indians. University of Texas Press. Austin. USA.

PUERTA, F. (2005). Análisis de la forma y sistemas de representación. Universidad Politécnica de Valencia. España.

RAMÍREZ RODRÍGUEZ, R. (2001). Atlanticú : el origen de el Tajin, Una exploración sobre la llegada del hombre a América. Universidad Veracruzana. México.

REYES LÓPEZ, M. A. (1996). Análisis cuantitativo de la cerámica de El Tajín, Ver. Tesis Profesional. Facultad de Antropología. Universidad Veracruzana. Xalapa. México.

SPINDEN, E. S. (1993). The Place of Tajin in Totonac Archaeology. American Anthropologist. (vol. 35). USA.

SOLIER, W. D. (1939). Principales conclusiones obtenidas del estudio de la cerámica arqueológica de El Tajín. Actas del XVII Congreso Internacional de Americanistas. INAH. núm. 2. México.

SONDERENGUER, C. (1989). La Pirámide Templo en Mesoamérica. Morfoproporcionalidad. Arte al dia. Argentina.

-(2003). Manual de Iconografía Precolombina y su Análisis Morfológico. Nobuko. Argentina.

-(2003). Sistemas Compositivos Amerindios. El Concepto. Nobuko. Argentina.

TRIGOS LANDA, M. A. S. (2003). Programa de ordenamiento del entorno de la zona arqueológica de El Tajin. Tesis 
Profesional. Universidad Veracruzana. Xalapa. Veracruz. México.

TORRE, C. D. L. (1976). El Tajin : guide official. Instituto Nacional de Antropología e Historia. México.

TUGGLE, D.H. (1966). Cultural Inferences from the Art of Tajin, México. Tesis de maestria. University of Arizona. Tucson. USA.

-The Columns of Tajin, Veracruz, México, Ethnos. Núm. 33.

-El significado del sangrado en Mesoamérica: la evidencia de El Tajín, Boletín Núm. 42, INAH, México.

WILLIAMS GARCÍA, R. (2001). Tradición oral en Tajin = Taqalhchiwin lilatamat nak Tajin. Universidad Veracruzana. Veracruz. México.

WILKERSON S, J. K. (1971). Un yugo in situ de la región del El Tajin. Boletín del Instituto Nacional de Antropología e Historia 41. México.

-(1986). El Tajin : Una Guia para visitantes. Universidad Veracruzana. México.

WONG, W. (2007). Fundamentos del diseño. Editorial Gustavo Gili. España.

ZALETA, L. (1991). Tajin, misterio y belleza. Grupo Editorial EON. México.

\section{ARTICULOS EN PUBLICACIONES PERIÓDICAS}

BRÜEGGEMANN, J. K. (Dic. 1993-Enero 1994). Tajin en Números. Arqueología Mexicana. Vol. 1. Núm. 5. p.57

-(1993). La ciudad de El Tajin. Arqueología Mexicana. Vol.1. Núm.5. p. 29. 
JIMÉNEZ LARA, P. (2002). Cuadernos de Trabajo No.15: Arquitectura y poder en El Tajín. p. 11 y 12.

LEÓN PORTILLA, M. (2002). Mitos de los orígenes en Mesoamérica. Arqueología Mexicana. Vol. X. Núm. 56, Vol. X. pp. 20-27.

LÓPEZ AUSTIN, A., y López Luan, L. (2002). Tiempo Mesoamericano. Arqueología Mexicana. Edición Especial Núm. 11. p. 7 .

-(2002). La magia y la adivinación en la tradición mesoamericana. Arqueología Mexicana. Vol. XII. Núm. 69. pp. 20-29.

MARCUS, J. (2000). Los calendarios prehispánicos. Arqueología Mexicana. Núm. 41. p. 14.

URIARTE, María Teresa. (Enero-Febrero 2010). Las pirámides y la integración plástica. Arqueología Mexicana. Vol. XVII. Núm. 101. p. 53.

SOLIS, F. (2003). El Tajín, sitios arqueológicos del estado de Veracruz. Guías Arqueológicas de México Desconocido. p. 45

TAUBE, K. (Enero-Febrero 2002). La serpiente emplumada en Teotihuacan. Arqueología Mexicana. Vol. IX. núm. 53. pp. 3641.

TENA, R. (2005). El calendario mesoamericano. Arqueologia Mexicana. Núm. 4. p. 5. 


\section{ARTICULOS O PONENCIAS EN CONGRESOS}

MARTÍNEZ TORÁN, M., Pérez García, Ma. Del Carmen, Martínez Lázaro, I. y Boix Doménech, M. (2008). Obtención de modelos digitales a través de técnicas de escaneado $y$ reconstrucción $3 D$ aplicadas a la restauración y conservación: reflexiones sobre la reproducción de duplicados y réplicas escultóricas. Actas del $17^{\text {th }}$ International Meeting on Heritage Conservation. Vila-Real, Burriana y Castellón. UPV. pp. 221226. 